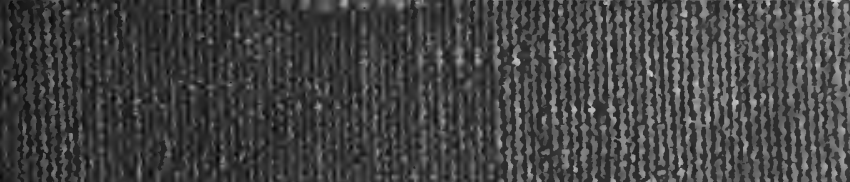

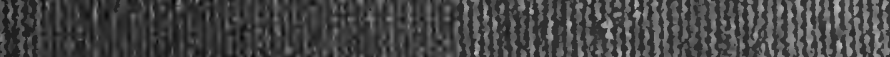
ty Q5)

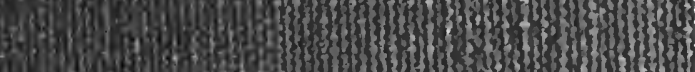
Fing Sa) 9.6. 20.6) for. (5) 13 :

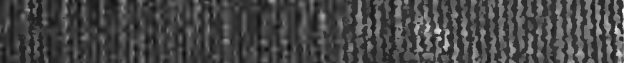

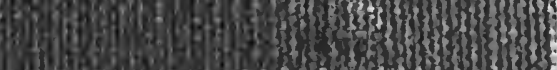
if

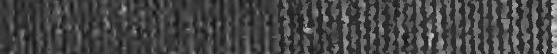
Lon. 10 6.7. YA.

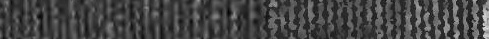
30.5 I0. fyogh

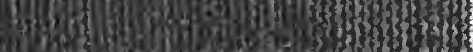
1.1. 690. Hoxim

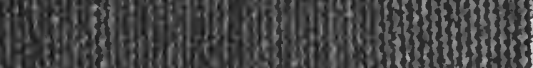
W. Shy B.t. 352. B. 210. I 13. 
Digitized by the Internet Archive in 2008 with funding from Microsoft Corporation 


\title{
FRENCH LITERATURE OF THE GREAT WAR
}

BY

\author{
ALBERT SCHINZ \\ PROFESSOR OF FREXCII LITERATURE \\ AT SMITII COLLEGE
}

\section{APPLETON AND COMPANY NEW YORK




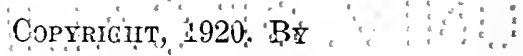 \\ D. APPLETON AND COMPANY}


Great heart of France which has withstood so well The blasts of battle and the gates of hell

Our love is thine. ...

Edicxd Vaxce Cooke.

\author{
Oui, mon coq glorieux, \\ C'est toi qui fais lever l'aurore! \\ Rostand, Chantecler.
}





\section{FOREWORD}

The output of French war literature has been very great. This may not seem surprising when one thinks of the importance of the crisis through which France has just passed, but it is so when one realizes how that country had to exert all its strength to keep itself from being submerged; literature in such circumstances, is more than ever a luxury.

How shall we define the scope of this study? In one sense, we have been very broad in our selection of material. Apart from works dealing technically with the history of the war, and which we have left out, we have surveyed all kinds of books; for literature has no domain of its own. According to time and circumstances, it may include almost anything. With Ronsard and Victor Hugo, it is poetry; with Corneille and Racine it is drama; but it is philosophy with Descartes, Malebranche and Renan; ethics with La Bruyère and Marmontel; theology with Bossuet and Joseph de Maistre; medicine with Claude Bernard and Pasteur; psychology with Montaigne, Marivaux and Le Sage; history with Voltaire, Michelet and Taine; politics and political economy with Fénelon, Montesquieu, Rous- 


\section{FOREWORD}

seau and Fustel de Coulanges; etc., etc. War,and especially the Great War,-stirs up thoughts along all these lines, and it would be very arbitrary to decide which writings must be regarded as literature, and which must not.

In another sense, it has been necessary for us to narrow our field by imposing upon ourselves considerable restrictions. It has often been very difficult to resist the temptation of including,for the sake of full treatment, and in order to do justice to all,-many excellent works. Too bulky a volume would have defeated the end which we have in view. The following course seemed the best one in the circumstances: To make a first selection according to a general criterion of excellence and originality. This was, in many cases, an easy matter because excellence and originality went together in the same books, as, for instance, in Benjamin's Gaspard; Barbusse's Le Feu; in the anonymous Lettres d'un Soldat; in Erlande's En Campagne avec la Légion Etrangère, Duhamel's Vie des Martyrs, Jaques Blanche's Cahiers d'un Artiste; Y....'s Odyssée d'un Transport Torpillé; or, on the stage, in Bernstein's Élévation; or, in poetry, in Verhaeren's Ailes Rouges, in Mercier's Prières de la Tranchée, and in Marc Leclere's $L a$ Passion de Notre Frère le Poilu.

Very often, however, there were several exviii 


\section{FOREWORD}

cellent books representing the same important trend of inspiration. In these cases we had to eliminate with a view to avoiding monotony. The writer believes that he has succeeded in bringing in a new note with the treatment of each new volume, but he frankly acknowledges that the choice between works of a similar nature has been determined at times by causes imponderable. The determining factor may have been the verdict of the French reading public, or it may have been subjective preference. For instance, the author would not care to be called upon to aceount with scientific thoroughness for his selection of 'Thomas' Les Diables Bleus and Péricard's Ceux de Verdun, in preference to Belmont's Lettres d'un Officier de Chasseurs Alpins, Mareel Dupont's En Campagne 1914-15, and later, L'Attente, ${ }^{1}$ or Dieterlen's Le Bois le Prêtre, Dubarle's Lettres de Guerre, Jubert's Verdun, ete. Again some may think that Lieut. E. R. (Tuffrau's) Carnet d'un Combattant, Roujon's Carnet de Route, Paulhan's La Guerre Appliquée, Julia's Mort du Soldat, or many others, deserved just as much

1 Perhaps the reason why Dupont was not chosen is because he is so good that no comment can be made which is not superfluous. The sixty editions through which his first volume ran before the close of the war are a very just measure of the value of that remarkable work. 


\section{FOREWORD}

to be analyzed as Rédier's Méditations dans la Tranchée or Génevoix's Sous Verdun or Delvert's Histoire d'une Compagnie. The same problem confronted us in dealing with poetry, the stage, and the novel, although it was rather easier to come to a decision in those cases than when dealing with war recollections or analyses of the psychology of the soldier.

Many readers are guided in the selection of their books by the fame of the authors. At no time is the name of an author a certain guarantee of the excellence of the work, and in the special case of war literature, it offers none whatever. Indeed, none of the well known pre-war writers have produced during the war anything that commands attention as a masterpiece; and this is quite natural, for veterans in the field of literature do not belong to the war generation and can therefore hardly be its spokesmen. Anatole France, Pierre Loti, Maeterlinck, Bourget, and Bazin have added nothing new to what they had been saving for many years previously; Rostand's fame would suffer heavily if he was judged by his writings since 1914; fortunately for him his two best war-poems Cyrano de Bergerac and $L$ 'Aiglon had been written long before the war. Such men as Porto-Riche, Bataille, 


\section{FOREWORD}

Abel Hermant have fallen below the mark they themselves had set in the past. Some, like Henri de Régnier, the war seems to have entirely paralyzed.

The only two eases in which one may be tempted to take exception to our statementthat writers whose reputation was established before the war have rarely done any original work since 1911-are that of Bernstein in his drama L'Elévation, ${ }^{1}$ and that of Verhaeren, stirred up to really powerful satire by the wrong done to Belgium, his own eountry, in his Ailes Rouges de la Guerre.

So the reader must expect to come across new names ehiefly. Indeed, one of the most interesting features of the war literature is that it acquaints us with many hitherto unknown but admirable writers.

\section{One more remark.}

As everywhere else, war has ereated extraordinary eireumstances in the domain of literature; this is true not only as regards the eontents of the war books, but also as regards the forms in which the writers presented their thoughts. War literature created its own style. Quite

1 This play, however, has been severely judged by several French erities. 


\section{FOREWORD}

naturally the traditional distinctions of descriptive, dramatic, lyric, and epic styles were disregarded. In most cases the form adopted was that of War Recollections. By far the greatest part of war literature is written in unconventional style and will be described in the first part of the following work.

At the same time, in some cases, especially in that of lyrism, and to some extent in that of the stage, but less in that of prose fiction, the conventional literary genres continued to obtain with good writers. We will deal with these products in a second part.

The reader will find at the end of the volume additional data on the following points :

I. Indications where to find more detailed bibliographical information than we could offer in the text, concerning the literature of the war.

II. Documents relative to the war, not coming within the domain of literature, but complementary to it; history of the pre-war period; chronicles; discussions and comments relating to special phases of the war; appreciations by military critics; descriptions of great battles by non-combatants; life in the trenches; the part played by various branches of the service; psychology of the soldier; military vocabulary and 


\section{FOREWORD}

slang; illustrated war-books, and war-newspapers.

III. A catalogue-not a full one indeed, but as carefully drawn up as seemed possible-of the best French war-diaries and volumes of warrecollections.

This book would not have been completed, at least so soon, had it not been for the kind assistance-which sometimes was almost a collaboration-given by Professor Osmond T. Robert, our colleague in the French Department at Smith College. To him we owe most hearty thanks.

Towards another of my colleagues, Miss Helen Maxwell King, we feel greatly indebted for the expert help which she gave in the ungrateful task of drawing up the Index.

We express our gratitude also to Professor E. P. Dargan, of the University of Chicago, who very kindly went over our manuscript, offering valuable suggestions.

We wish further to acknowledge the courtesy of the editors of various periodicals which allowed us to make use again of material which had appeared, above our signature, in their columns: The Journal of Philosophy, Psychology and Scientific Methods; The American xiii 


\section{FOREWORD}

Journal of Psychology; Medicine and Surgery; Modern Philology; Publications of the Modern Language Association of America. And perhaps we ought to mention also the New International Year-Book where we had recorded before-although in much briefer form-the output of the French Literature of the Great War.

Albert Schinz. 


\section{CONTENTS}

\section{PART I}

I. Period of Fiotional Page Ately After tile Octbreak of the War . 5

II. Period of Documextation-Commexcisg About tile Sprixg of 1915 . . . . . . 27

III. Period of Pinlosopinical axd Political Considerations Siggested by the War (More Especially Sixce the Begixisg OF 1917) . . . . . . . . . . . . . 230

\section{PART II}

I. Poetry of the $\mathrm{W}_{\mathrm{AR}}$.

II. The Stage and the War . . . . . . 338

III. War-Time Fiction . . . . . . . . 363 Epilogue . . . . . . . . . . 381

\section{APPENDICES}

I. Bibliography . . . . . . . . . . 391

II. Documents Relative to tile War . . . 397

iII. Catalogee, ix Alpiabetical Order, of Some of the Best War Diaries axd RecollecTIONS . . . . . . . . . . . . 405 
. 


\section{INTRODUCTORY}

It is possible to distinguish three periods in the war literature of Franee between 1914 and 1918. The first was one of spontaneous, sudden and strongly emotional reaetion, following immediately the first bewildering shock; the second, one of documentation on the eauses of the war and on the war itself; and the third, a period of calm philosophical eonsideration of all that was involved in the gigantie struggle, characterized by a reconsideration of the past, a weighing of the present, and especially an effort to prepare for the future.

It needs searcely to be said that although,as indeed was mite natural.- - the lyric and satirical note nrednminated in the first period, memnir literature in the second, and philosophieal escars and treatices in the third, no period produced one trone of literature to the exclusion of all others. A few philosophical writings began to appear very early in the war, and the puhlication of documents of historical and psyehological interest by no means came to an end when the theorists became more numerous: neither, indeed, did ther eease to appear before 


\section{INTRODUCTORY}

the end of the war and even after; and at all stages of the conflict, there has been abundant reason for emotional inspiration.

But, while fully conscious of those facts, we have adopted the above classification, first because it does actually correspond, in a general way. to what happened, and also for the sake of clearness in discussing the subject. 
PART I 


\section{FRENCH LITERATURE OF THE GREAT WAR}

\section{CHAPTER I}

PERIOD OF EMOTIONAL REACTION-IMMEDIATELY AFTER THE OUTBREAK OF THE WAR

THE war took almost every one by surprise. The first expression of thought, after the immediate danger was passed, that is, after the first battle of the Marne, was an outburst of indignation at the treacherous attack which had been made by the Central Powers, and also at the blindness of the French people who had allowed themselves to be lured into a fatal, sentimental quietude by the stupendous hypocrisy of their neighbors on the Eastern frontier. To this indignation were soon added the anger, disgust and horror caused by the atrocious application by the German army, in Belgium and Northern Franee, of the barbarian policy of terrorization. These manifestations of burning patriotism 


\section{FRENCH LITERATURE OF THE GREAT WAR}

appeared in the few newspapers which did not stop publication, or which did so only for a very short time: Le Temps, Les Débats, Le Figaro, L'Echo de Paris, Le Journal, Le Matin, L'Homme Libre, and then L'Homme Enchaîné, and the still less numerous periodicals like the Revue des Deux Mondes, Revue de Paris, l'Illustration, la Revue Hebdomadaire, la Revue, les Annales. Towards the end of the spring of 1915, as France began to return to more normal conditions, the articles referred to above began to appear in book form.

But the young men had dropped the pen to grasp the sword, and the men who wrote were, for the most part, well advanced in years. Many of them, it is true, were men of high standing, whom France had learned to regard as the intellectual leaders of the day; but the fact remains that their books, in spite of their beauty and stirring eloquence, are not directly representative of that young France which was at grips with the enemy; and, as time passes, the glory of those first productions will fade before that of the more authentic works of the actual fighters.

Nevertheless, those early books recorded the pulse of France during the first weeks of the 


\section{EMOTIONAL REACTION}

world-tragedy, and for that reason, some of them, at least, deserve to be recalled here.

From the very beginning, Henri Lavedan sueceeded in giving a very lofty tone to his weekly articles in l'Illustration. The re-issue of those articles in book form under the title of Les Grandes Heures, will remain the best expression of that rousing and cementing of the national spirit whieh every one now calls l'Union Sacrée. In most other articles, one hears much more often the harsh strains of intense anger and of satire directed against Germany, than the harmony of the epic song of Franee's heroism.

The titles of the following books give a very clear idea of the nature of their contents. Pierre Loti, La Grande Barbarie (1915), La Hyène Enragée (1916), Quelques Aspects du Vertige Mondial (1917), and L'Horreur Allemande (1918); Paul Margueritte (author of Une Époque), Contre les Barbares (1915), and later, L'Immense Effort (1915-16); Jean Aicard, Des Cris dans la Mêlée (1915); Jean Riehepin, Prose de Guerre (1915); Mme. Juliette Adam (the famous editor of the Nouvelle Revue, who boasts that she has never accepted the treaty of Frankfort), L'Heure Vengeresse des Crimes 
Bismarkiens (1915). Paul Adam, Dans l'Air qui tremble (1915), and later, La Terre qui tonne (1917) ; to which may be added Péladan's L'Allemagne devant l'Humanité and Le Devoir des Civilisés (1915), with its, at times, brilliantly eloquent anathemas; and also two more objective works which tell the story of the German atrocities in the previous war: General Canonge's Histoire de l'Invasion Allemande en 18\%0-r1, and Gabriel Langlois's L'Allemagne Barbare. This latter book contains a remarkable chapter relating how the anthropologist, Quatrefages, had refused to believe the reports of German barbarities, until he saw the enemy stupidly attempting to destroy the magnificent scientific collections of the Museum in Paris.

Even philosophical minds could not remain calm in that hour of exaltation. In a lecture before the Académie des Sciences Morales et Politiques on September 14th, 1914, Bergson denounces the philosophers of Germany as aiders and abettors in the development of the ferocious war organization of that country. Germany's philosophy he regards as "only the transposition in terms of the intellect, of her brutality, her greed, and vices." Neither is Anatole France quite free from passion, although his 


\section{EMOTIONAL REACTION}

style makes acceptable every page of his Sur la Voie Glorieuse, and Ce que disent nos Morts. Another Freneh "sage," Rémy de Gourmont, calls his volume of essay's P'endant l'Orage, and a second volume, published after his death in 1915, bears the title of Dans la Tourmente.

Among the books in which the impeachment of Germany plays so great a part, there are some which are partieularly moving beeause we know that their authors have suffered more than others. We refer to the books of Belgian and Alsatian writers, such as Maeterlinek's Débris de la Guerre, and Verhaeren's La Belgique sanglante and Parmi les Cendres. To this elass also belong Pierre Nothomb's Les Barbares en Belgique (first published in the Revue des Deux Mondes), and the works of l'Abbé Wetterlé, the distinguished and courageous representative of Alsace-Lorraine in the Reiehstag in pre-war days. We eommend to the reader's attention his Propos de Guerre,-the second volume of which is inspired by stinging satire,-his l'Allemagne qu'on voyait et celle qu'on ne v'oyait pas, and, of course, his Ce qu'était l'Aisace-Lorraine et ce qu'elle sera (1915).

It is not our intention to dwell at length on this emotional literature although it was fully 
justified by the circumstances. We wish, however, to assign it an honorable, though small place in the literature of the war; this, we cannot do better than by quoting a very short extract from the Preface of Maeterlinck's Débris de la Guerre. The few sentences express the spirit of all the books above mentioned; they do so in the words of one, who, more than any other, has a right to speak, not only because he is a Belgian, but also because,- - as he himself remarks,-he had been until then conspicuously free from any harshness or ill-feeling towards his fellow men: "The reader will find, for the first time in the work of one who has hitherto abused no man, words of hatred and of malediction. I would gladly have left those words unsaid ... I have been forced to utter them, and I am as much surprised as I am maddened at what I have been constrained to say by the force of events and of truth. ... There are crimes which obliterate the past and close the future. In eschewing hatred, I would have shown myself a traitor to love. I tried to lift myself above the fray; but the higher I rose, the more clearly did I see the madness and the horror of it, the justice of our cause and the infamy of the others'. It is possible that some 
day, when time has dulled the memory and restored the ruins, wise men will tell us that we are mistalien, that our standpoint was not lofty enough, that everything can be explained and forgiven and that we must make an effort to understand; but they will say so only because what we know has been forgotten, and what we behold has not been seen.",

Two other writers who have also echoed the emotions of the war, deserve special mention, because, being younger than those whom we have already discussed, they ean be considered as actually speaking for the war generation, and also because, for quite a number of years, they had been regarded as "leaders" of young France. The first is Maurice Barrès, a member of the French Academy and of the Chamber of Deputies, and the President of the Ligue des Patriotes. His almost daily articles in the Echo de Paris were, during the first weeks of the war, a magnificent inspiration to the French people, and fully justify the general title under which they were re-issued in a series of volumes: L'Ame Française et la Guerre. The first volume of the series, L'Union Sacrée, takes us from July 12th to October 31st, 1914, describes the 
political situation on the eve of the war, the great retreat, and the battle of the Marne; the second volume, Les Saints de la France, takes us to the end of the year 1914, and tells the story of the battles in Flanders and of the descent into the trenches. The other volumes are: $\boldsymbol{L} \boldsymbol{a}$ Croix de Guerre, Amitiés des Tranchées, Voyages de Lorraine et d'Artois, Pour les Mutilés, Le Suffrage des Morts. One of the finest utterances of Barrès is the lecture (Les Traits éternels de la France) which he delivered in London, on July 12th, 1916, to the members of the British Academy, and in which he drew some very striking parallels between the French Knights of the Middle Ages who fought for Christendom and for the Church, and the modern heroes who are fighting, in the same spirit of self-sacrifice, to save a civilization in which love, and not violence, is triumphant. ${ }^{1}$

During the third year of the war, Barrès wrote, in addition to his chronicle of the war, one of the most moving books imaginable on the religion of the Soldier: Les Familles Spirit-

1 An American edition, with excellent notes, was prepared by F. Baldensperger and issued by the Yale Press at the end of 1918. There is also an English translation by Miss Corwin (Yale Press). The original title of the lecture was: Le Blason de la France, ou ses Traits éternels dans cette Guerre et les vieilles Epopées. 
uelles de la France (this work will be referred to again later); and, in the fourth year a smaller one, De la Sympathie à la Fraternité des Armes, Les Etats-Unis dans la Guerre (Bibl. FranceAmérique).

The second of those younger authors is André Suarès: a man possessed of a genius akin to that of Charles Péguy. While Péguy was pouring out his soul in fiery prose in the Cahiers de la Quinzaine, Suarès was, since 1909, the leading spirit of the Nouvelle Revue Française; his stirring, vigorous, mystic style, full of striking, at times apocalyptic, images, was a perfect instrument with which to arouse not only the intellectual youth, but the whole of Franee. His articles have been collected under the general title of Commentaires sur la Guerre des Boches. In the first volume, Nous et Eux, he shows in elear definite formulas, how fundamentally, how "racially" different are the French and the German minds. In the second volume, C'est la Guerre, he returns to his assertion of a real difference of "race," and describes the war as a "zoölogical" contest. He ean admit of no neutrals in this struggle between the powers of darkness and those of light. One of the best of his books is Ceux de Verdun (1916, 138 pp.), in 
which he pauses, for a moment, in his virulent attacks upon Germany to proclaim the glory of the heroes of France. He relates the great epic of Verdun in a terse, lapidary style, reminiscent of the noblest passages in the ancient Hebrew Prophets. The power of his beautiful rhythmieal prose is irresistible.

But the intense patriotism of Suarès does not prevent him from being at the same time a thinker of remarkable independence of judgment. He reminds us at times of the late Rémy de Gourmont. He has published, from time to time, in the elegant issues of the Nouvelle Revue Française, pamphlets which are stimulating to an extraordinary degree. And Suarès has the courage of his convictions. A man must be bold indeed, who dares to publish, while France is at war with Germany, sentiments like those which we quote below, and to which he gave expression in the course of a discussion on the advisability of discontinuing the study of Kant. His assertion that Kant is Cartesian, that he has developed to their fullest extent the principles of Descartes, we must leave to the judgment of metaphysicians; but the ethics of Kant, and his polities are of very general interest to-day. In $R e$ marques II, (December, 1918) Suarès says in 
that eonnection: "To represent that great independent mind as the type of Prussianism, to make of him the philosopher of the German State, is an act of deliberate bad faith; or, to put it more plainly, it is a lie.

"I find the answer to that lie in the first of the Articles, where Kant has written: 'The political eonstitution of each state must be republican.' What a very Prussian trait that is, to be sure! And here is another: Kant is blaming the government of kings for the barbarities of war and he writes: 'the Sovereign glories in his power to dispose aeeording to his faney, and without taking any great personal risks, of the lives of several thousands of men who are cver ready to sacrifiee themselves for a eause which is no eoncern of theirs.' And then Suarès, turning on one of his own eountrymen, eontinues: "I know a Prussian who is also a Roman Catholie; a feudalistic Prussian; a Prussian as to his ethics; a Prussian by his royalist and absolutist polities; a Prussian in his riews of peace and of war; whose thoughts are Prussianly antagonistic to the Republie, to the rights of men and to the freedom of thought; and who expresses those thoughts in the very terms of Moltke and of the German General Headquarters. That man is 


\section{FRENCH LITERATURE OF THE GREAT WAR}

Joseph de Maistre. Kant is the very antithesis of de Maistre. Kant represents the spirit of eighteenth century France and of the Revolution. De Maistre is already dead 'up to his throat.' The ax is poised above his head as above the thick nape of Berlin; but the spirit of Kant still lives.',

* * * *

Before bringing this chapter to a close, we wish to speak of two men upon whom the war has produced very contrary effects: Gustave Hervé and Romain Rolland. Before the war, Hervé had preached with so much vehemence the doctrines of socialism, internationalism and antimilitarism, that he had been arrested on a charge of treason, tried and condemned to prison. ${ }^{2}$ Very soon, however, after the outbreak of the war, he acknowledged with a eandor which does him honor, that he had been mistaken. Hervé is a politician, but he is nevertheless upright and sincere, and a stranger to the subtleties of political arrivistes. He has turned with burning indignation against the German socialists who have

2 It was Herve who, in 1915, wrote that famous book Leur Patrie which assailed the idea of love for one conntry only, and which called forth Péguy's beautiful Notre Patrie.-A good article on Hervé will be found in André Maurel's Six Ecrivains de la Guerre (Paris, 1917), pp. $73-96$. 
shown themselves to be false brethren. Since the begiming of the war he has published three books,--all of them reprints of his articles,-under the titles of Après la Marne, ${ }^{3}$ La Patrie en Danger, and La Muraille. In this last book, he preaches the gospel of "France" with all the conviction and eloquence which formally characterized his preaching of the gospel of "Humanity." His newspaper which, before the war, was called La Guerre Sociale, has, since 1914, been known as $L a$ Victoire. ${ }^{4}$

As for Romain Rolland, he has moved in a direction opposed to that of Herré. In Jean Christophe he had judged with some severity the materialism, laek of taste, and industrialism of

3 In this first book, composed of articles which appeared between November, 1914, and February, 1915, the contrast with his former writings already comes out very strikingly. See especially the articles Jusquau bout (pp. 44-47), A Sudekum, Socialiste du Kaiser (pp. 294-297), and Le Pot aux Roses (pp. 310-315). The titles of those articles indicate the spirit in which they were written.

4 Hervé had also written, some years before, a very original Histoire de France pour les Grands (1904) in which he avoided as much as possible mentioning the names of kings and of battles, because civilization has no greater interest in kings tlian in any otlier people, and because wars, far from furthering the progress of eivilization, usually set it hack. A number of teachers with socialist leanings adopted the book in their classes, but the government quickly took action, forbidding the use of it in any school within the jurisdiction of the French Republic. 


\section{FRENCH LITERATURE OF THE GREAT WAR}

Germany; Jean Christophe was obliged to come to France to find an atmosphere congenial to his artistic temperament. It is true that he had not found in the conventional artistic milieus of Paris, any response to genuine art; but his hopes were with the people of France, the people who had produced Joan of Arc . . . people of such sterling moral qualities were to be found only west of the Rhine. When the war broke out, Rolland was shocked by the passionate outcry against Germany which spontaneously arose in every quarter of the civilized world. He tried to retain his self-possession, but his too great anxiety to remain impartial led him to make such great concessions to the German point of view, that he soon appeared to many of his countrymen as a traitor to their cause. Even the Manifesto of the ninety-three German intellectuals, in which, deliberately or unintentionally, many facts damaging to Germany were passed over in silence, did not induce him to change his attitude; nor was he affected by the failure of the appeal which he addressed through Gerhard Hauptmann to the German men of letters; he still continued, after that, to sit in judgment upon the contending parties. So convinced was he of the correctness of his attitude, that in his 
Au-dessus de la .êlée (1915-16) he asks men of unprejudiced minds to pronounce between him and his opponents.

Few publications have stirred up more resentment in France, or ereated more misunderstanding, than that book. The French people cannot understand how it is that Rolland fails to under. stand. And, indeed, it is strange that so intelligent a man should remain impervious to all arguments and explanations; for he pays not the slightest attention to them; he simply ignores them and continues to re-state,-eloquently enough, it must be admitted,- the riews which he has held since the beginning of the war. It seems as if the enormous suecess of Jean Christophe had to some extent impaired his judgment, and as if he aceepted in all seriousness the flattering assurance of some of his disciples, that he needs only to speak and the whole world will accept his words as gospel.

He did not or would not realize that it lay as little in the power of the French people, as in that of the Christian socialists or of the intellectual élite or of any one else, to put a stop to the fighting; unless, indeed, France was willing to yield, body and soul, to Germany. After the first battle of the Narne, from Geneva (where he 
has lived all through the war) Rolland took it for granted that everything was over. On September $15 \mathrm{th}$, in the article which gives the volume its title, and which has so endeared him to the pacifists, he exclaimed in terms astonishingly naïve: "Un grand peuple ne se venge pas, il rétablit le droit'": a great nation does not seek revenge, it reëstablishes Right-as if that was not exactly what France was trying to do in keeping up the fight; as if France, and England, and, later, America, had not accepted the long, wretched struggle which lasted four miserable years, precisely in order to make possible that "Haute Cour Morale," for which the heart of Romain Rolland was yearning ... away from his country!

One cannot deny, of course, the lofty inspiration of the anthor of Au-dessus de la Mêlée, but neither can one close one's eyes to his remarkable stubbornness. More than any of his opponents whom he constantly upbraids for their lack of openmindedness, he deserves the reproach of being prejudiced. He frequently commences his articles with abuse of Germany, superabundant sympathy for the French and very ligh praise of their splendid courage and noble behavior; and then continues: "But ..."-that exasper- 


\section{EMOTIONAL REACTION}

ating but, which means: "Now that I have patted you the back, listen to me who am able to dispense words of supreme wisclom." His insistence on his point of view beeomes, at times, intolerable, and ereeps into the very titles of his artieles: Inter Arma Caritas; Au Peuple qui souffre pour la Justice; Notre Prochain, l'Ennemi; ete.

Among the answers to Rolland, two of the most striking are Verhaeren's which appeared in the Revue de Paris and which ean be summarized in his own words: "One must not try to hold a seale when the enemy is brandishing a sword"; and the foreeful artiele by Benda in l'Opinion ${ }^{5}$ in which this writer says: "But you exaggerate, Sir, when you say that Justiee must be free from passion. Passion for the just eause, she must have." The sentiments of the Catholies were expressed by H. Massis in his pamphlet Rolland contre la France. See also Paul Hyaeinthe-Loyson's Etes-vous Yeutre devant le Crime? If one wishes to have also a poet's reaction, one will find it in the Sonate contre Romain Rolland, by .Jean Fontaine-Vive, in the volume Jeunesse ardente, quoted below.

5 Benda's article is to be found in his Sentiments de Critias (1917), to which we shall refer again later. 
But the most representative comments on Rolland's book are found in G. A. Henches' $A$ l'École de la Guerre (1918). Commandant Henches kept one of the best diaries of the war: Few soldiers have felt more keenly than he the horrors of the great tragedy; few have kept themselves so completely under control. And yet, this man who is generally so moderate even when referring to the Germans, is very severe toward Rolland. He denies him any right to speak. Rolland may be right, but Rolland has no voice in the matter, because, even if he is right, he has not reached his conclusions by means of valid premisses: Rolland has not seen the war. He is like a man who, firing a rifle for the first time, would happen, by some chance, to make a bull's eye. That success would not make a shooter of him; and his claim to dogmatize on matters of shooting would not be admissible. The following are a few quotations from Henches: "Rolland seems to me to be giving himself airs of moral superiority and of detachment which are distinctly out of place in present circumstances. . . . After the war, more than half the Germans,--if they are definitely beaten,-will assert that they had nothing whatever to do with the crimes; but, if by any chance, 
they had been victorious, how many, think you, would have protested? . . . The thoughts of Romain Rolland, even if they be true, earry no more weight than a ribbon or a trinket. You must risk your life in times like these, to have a right to uphold an idea, and those who have risked only their position, or their fortune, or who strive after notoriety, we regard as noxious. . . . Hatred we must have: hatred of self-seekers, hatred of liars, hatred of profiteers of every kind. It is easy, from a safe retreat, to utter words of kindness. But if Romain Rolland had witnessed the exodus of women and ehildren on certain September evenings in 1914; if he lived, as we do, among graves, he would be ashamed that he had dared to open his mouth. It may be that his ideas do not differ from our own, he is none the less guilty. We have a right to speak, he has not. Only those have a right to forgive who have suffered."

Commandant Henehes was killed in aetion.

After some time the public had eeased to pay any attention whatsoever to Rolland.

The attitude of Rolland was shared by an extremely small minority in France during the war, and since the cessation of hostilities things have not changed 


\section{FRENCH LITERATURE OF THE GREAT WAR}

much. There is, however, a manifesto of the "intellectuels combattants français aux intellectuels combattants du monde" which appeared in Le Cri du Midi and was reproduced without comment in the Mercure de France, in April, 1919, and from which we quote the following extracts: "Our hands which in spite of us were steeped in blood, are to-day eager to take up, in hearty coöperation with you the task of world reconstruction. . . . The din of battle has never robbed our minds of their serenity. . . Fighting intellectuals of those countries which yesterday were at war, we are impatient to renew with you intellectual and friendly relations. Intellectuals of the world, we know that those of you who share our sentiments are numberless; we know that for fifty months you have dragged out, behind the appearance of serene wisdom, existences as miserable as those of guilty souls. It behooves us to set to you the solemn and good example of wise conduct. . . We alone in the clash of fire and steel have had the courage to retain our faith in the illuminating and civilizing power of reason."

Rolland, who had distinctly not been a "combattant," could not sign this document; the chief name at the bottom of it is that of Barbusse, the author of $L e F e u$, of which we shall speak presently. The other eleven are men of much lesser note. In July, however, Rolland wrote a manifesto himself, in the very same spirit, and in which he seems as far as ever from realizing the concrete problems which the world has to face. He speaks of the "alliances humiliantes de l'esprit," of the duty of the intellectuals 


\section{EMOTIONAL REACTION}

to "point to the polar star in the turmoil of dark passions," "montrer l'étoile polaire au milieu du tourbillon des passions dans la nuit," and then hails the People of the future "one, universal, suffer-

- ing, stumbling but rising again," "unique, universel, qui souflre, qui tombe et se relève." . . . This piee of oratory has elicited a counter-manifesto which was published in the Figaro of July 19 by a group of patriotic writers, among whom was H. Massis (see our chapter III, below, on Philosophy during the Great War). They ealled it "Pour le Parti de l'Intelligence"-distinguishing thus between themselves and the "intellectuels" whose leanings are towards internationalism and perhaps even towards Prussianisin.

They want to build the future on distinctly national ideas, eounting among these a return to the leadership of the Catholic Church. This reply was signed not only by nationalistic and eatholie writers, as Massis, Bourget and Francis Jammes, but also by men like Henri Ghéon and Binet-Valmer. All these discussions when so much action is needed are somewhat disconcerting.

It may be interesting to recall here another manifesto, that written by Gerhard Hauptmann, in Germany, who had refused ruthlessly to take the olive braneh extended to him by Romain Rolland in 1914. In 1918, shortly after the armistice, his tone had changed; "A terrible experience," he says, "has proved to us that hatred does not pay. ... Relentlessly and awfully, God's designs have triumphed over those of men. . . For a thousand years, tlie 
FRENCH LITERATURE OF THE GREAT WAR

German nation has lived through no experience comparable to that of these latter days." . . .

For further data relative to the Rolland controversy, ef. Vic, Littérature de la Guerre, i. 349-351. 


\section{CHAPTER II}

\section{PERIOD OF DOCUMENTATION-COMMENCING ABOU'T THE SPRING OF 1915}

\section{Some Soldier Types in War Novels}

WE now come to those books which relate much more objectively than those referred to previously, the facts connected directly or indirectly with the prosecution of the war.

As the conflict progressed and assumed formidable proportions, changing its character from that of a war of nations in whieh national and political aims strove for mastery, to that of a world war in which great human principles were involved, it was both inevitable and imperative that the lyric and epic notes should die down. In the spring of 1915 , the more intelligent had already realized how helpless are strong emotions to solve great problems; that the old "eliehés" had served their purpose and that it was time to diseard them; what the seriousness of the hour demanded then was a deep, clear, practical, sober apprehension of the realities of the hour. 
The most immediate interest, of coursc, was focussed on the soldiers who were waging the war. Some men of letters soon began to make use of what had been for many years the most common medium of art, the novel. We must, however, beg leave to draw here a sharp distinction between two kinds of novels dealing with the war.

The one we will call War-Novel proper, in which the authors work up documents or personal experiences in order to make us see more deeply the significance of war itself; they apply the realistic theory of art which has been so well defined in Maupassant's Préface to Pierre et Jean; their aim is to rearrange facts in a manner which is more exact perhaps than reality but more indicative of the internal order of things, and with a view to bringing out more convincingly than mere contingencies have done, some aspects of the war which seem to them worth emphasizing.

The other we will call War-Time-Novel; it is the novel in which the war has been used merely as a background for some story not necessarily connected with it. And of course it cannot be denied that war offers wonderfully dramatic and romanesque situations; but there is probably 


\section{PERIOD OF DOCUMENTATION}

no love story, no tragedy, no idyll, or intrigue of any sort which absolutely requires war as a background the separation of lovers, jealousies, even the Enoch Arden theme, or the marriage with a man who has become a eripple, have no organic connection with war.

We are not eoneerned for the present with such War-Time-Novels, however great their artistic value may be (they will be dealt with at the end of Part II) but only with War-Novels proper.

In order to estimate rightly the value of warfiction as a contribution to our knowledge of the war, two facts should be borne in mind: the first is that no aecount of any event can ever be altogether objective; even the most matter of fact war-diary has required seleetion (and consequent rejection) of material, in its composition, and moreover presents that material from the standpoint peeuliar to some one author; that selection and that standpoint constitute the subjective or fietional element in the work. The second fact is that in a work which purports to represent and to explain the war, the element of fietion must be redueed to a minimum. The distinetion between the two genres-War-novels and 
War-diaries - thus tends to disappear, and whatever actual fiction there is in war-novels may be legitimately disregarded in estimating their value. Indeed the reading public makes so little of that distinction that it very easily regards war-novels as war-recollections; and very rightly so when the authors have had personal experience of the facts which they relate either on the firing line, or elsewhere.

At the same time, since the authors are aiming at giving to war novels as much aesthetic force and unity as possible - which they accomplish by developing or condensing, or at any rate re-focussing such episodes as they have especially selected-they must, if they are successful, produce something which from an artistic standpoint is superior to the mere chronological record of war episodes in memoirs and recollections.

Three War-novels stand out as the best attempts to depict soldier types of the Great War. All three liave been widely read.

The first is René Benjamin's Gaspard (1915). ${ }^{1}$ As a literary product, this book will hold its own, not only against the other more recent war books, but long after the war. Gaspard will re-

1 It was awarded the Prix Goncourt for 1915, and the Grand Prix du roman, by the French Academy in 1916. 30 
main a type in French literature, like Molière's Scapin, Daudet's Tartarin, Ilugo's Gavroche, or Aicard's Maurin des Maures. Indeed, the name "Gaspard" has already passed into the language to designate the intelligent, alert man of the people of France, or rather of Paris, the man of perfectly unsophisticated mind, who has a genius for acting kindly, is always ready to help, is doing, without any trace of self-consciousness, the most beautiful things; he is picturesque in speech, droll in manner, sound in mind as a red apple, transparent as glass, true as steel. This is the French soldier which the general public, especially abroad, likes to imagine-and perfectly legitimately; Gaspards are more likely to be found in the French army than elsewhere, although nobody would think that all French soldiers are Gaspards. ${ }^{2}$

The second book is Bourru, soldat de Vauquois $^{3}$ (1916) by Jean des Yignes Rouges. It

2 In 1916, Benjamin published another book, Sous le Ciel de France, and more reeently a third: Le Major Pipe et son Perre which is discussed further on in this same chapter, and since the war still another, Grandgoujon (1919).

3 Vauquois, a promontory, like a sentry between Verdun and the Forest of the Argonne, the only sector where the French, in spite of the most vicious attacks of the Germans, never withdrew one inch.

The book was crowned by the French Academy. 31 


\section{FRENCH LITERATURE OF THE GREAT WAR}

corresponds to the second period of the war, when the hell of the trenches rendered the life of the soldier much harder and stripped war of much of the heroï-romanesque which would otherwise, to some extent, extenuate its horrors. of course, in Gaspard we had not really much of war itself; we had the mobilization period, and just two episodes on the front; after the first, the wounding, nursing, and convalescence of Gaspard; after the second, his return home as a cripple. Gaspard was still a civilian, accidentally drawn into the war, but who had kept in the service his attitude of everyday life. For Bourru, civilian life is a dear memory only, he has become a soldier through and through, and very few pages of the book are not pictures of war, and of war of the fiercest kind in one of the worst sectors on the whole battle line. Bourru, unlike Gaspard, the quick-witted shopkeeper of Montmartre, is a peasant from Burgundy. He possesses all the intelligence, energy and quietness of disposition of his race, but lacks the cheerfulness of Gaspard; he is bourru ("a grumbler"'), but as a soldier he is just as brave and good as Gaspard; and perhaps because he has not that cheerfulness to help him out in his trials he is the more admirable in his behavior. 


\section{PERIOD OF DOCUMENTATION}

Although not as entertaining as Gaspard, he represents probably more truly the average fine soldier of Franee. ${ }^{4}$

The third book is Barbusse's Le Feu. ${ }^{5}$ It pictures the soldiers in the trenches when the third year of war was in sight. If the soldier could still be courageous in faeing grim reality, nobody could expeet of him, nobody, indeed, would accept as genuine, the everlasting eheerfulness of Gaspard; to expeet even the good-natured grumbling of Bourru would be a great deal. And indeed Le Feu is most depressing in tone and in its presentation of what people call the most realistic deseriptions of trench warfare.

Le Feu is by far the most-diseussed book of the war. What aroused so mueh commentpraise on the one hand and eritieism on the

4 Some very interesting information is given in the book about the underground warfare carried on by the sappers and miners (for which topie see also La fiuerre souterraine by Captain Danrit). Two other books were published in 1917 by J. des Vignes Rouges: Li.l me des chefs, and a novel: Ándré Rieu, officier de France, a psyehologieal study of a young "sous-lientenant" of 20 , a man of refinement, a poet, who knows how to remain above the ugly realities of the war while in the war.

Jean des Vignes Rouges is the nom de plume of Captain Taboureau.

5 Le Feu was awarded the Prix Goneourt for 1916. When the war ended, in November, 1918, that is two years after the publication of the book, 230,000 copies of it had been sold. 
FRENCH LITERATURE OF THE GREAT WAR

other-is the tone of the book, which appears to many to be not only realistic (which would be legitimate) but in part plainly cynical. There are those who see in so brutal a picture a sane, even a necessary reaction against the silly optimism prevailing in many quarters. The stupid representation of the French soldier as thoroughly enjoying life in the trenches-as eager for nothing save to die for his country, as charging the enemy always in a state of sublime exaltation, or, when lying wounded in the hospital, as burning with impatience to return as soon as possible to sacrifice whatever limb was left to him -seemed to them absurd, unjust, and immoral. Thus Barbusse, they would argue, was fully justified even in overdrawing the picture in order to counteract such misconceptions.

But there are those on the other hand who lay stress on another aspect of the problem. The book came out, they remark, just at the darkest period of the war, when France was finding it very difficult to keep up the spirits of her children in the terrific struggle. It was therefore very wrong, in such an hour, to speak words of discouragement. It is not right to tell the truth to a sick man when the truth may kill him, while 


\section{PERIOD OF DOCUMENTATION}

mere abstention from saying anything may allow him to pull through.

Moreover, Barbusse has been eharged with produeing a book which was realistie only in the sense of "shoeking," but not in the sense of "true." An army composed of men such as are described in Le Feu could never have achieved what the French army did achieve. Furthermore, the squad whieh Barbusse presents in his book is composed entirely of unthinking men, not one of whom is eapable of grasping the meaning of the struggle. ${ }^{6}$ French officers and soldiers have repeatedly protested against what they eonsider Barbusse's misrepresentations of the Freneh soldier; and they surely speak with authority. They have sometimes characterized the book as "eriminal." A vigorous protest by Major L. C. Elkenfelder, an Alsatian, appeared in the Chicago Tribune and was reprodueed on May 19th, 1918, in the Sunday edition of the New York Times. ${ }^{7}$

6 On this point the reader should consult Mauclair's several artieles in the Semaine Littéraire of Geneva, in the years 1916 and 1917 .

7 Here are the words of a man who has won great esteem among American scholars, Lucien Foulet: "The book contains some good, some bad; without entering into any detail I will tell you that as far as the life of 35 


\section{FRENCH LITERATURE OF THE GREAT WAR}

Our readers will of course recall the part played by minister Richelieu, in the famous literary "querelle du Cid"; the historian of the future may have to examine the part of another minister in the querelle du Feu. No secret is made, especially in the last pages of the book under consideration, of the author's disbelief in the idea of patrie. The question then arose: How was it that books much less outspoken on much less paramount issues should have been pitilessly censored while Le Feu was not? And how was it that this book belittling patriotism should have been allowed to come out just at the time when those very ideas were used by German propaganda in a desperate attempt to create a demand for peace in France? A plausible answer was made repeatedly and openly: because the minister of the interior was then Malvy, who was later charged with treason; Malvy allowed the book to pass (see the article in the New York Times already mentioned). ${ }^{8}$ A care-

the trenches is concerned, it is in no way a faithful rendering. I have passed twenty-one months in the trenches and I know what it is. As for the language of the 'poilu,' he idealizes it from certain points of view, and renders it extraordinarily vulgar at times." (From a private letter.)

8 Louis J. Malvy, Minister of the Interior in the Viviani, Briand and Ribot cabinets, was reckoned one of the most astute political figures in France. It was in 
ful reading of the book may, to some extent, absolve Barbusse of any active intention to aid the enemy. While, theoretically, he is opposed to purely national pursuits and advocates human ideals (he has again-said so since the war is over. See above, end of chapter I, pages 23-24), yet in this concrete case of the Great War he believes that France is waging a just fight. In other words, unless new arguments are brought forward, one can only make this statement, that German propagandists may have used the book of Barbusse in a way of which he himself may have disapproved. As far as the writer knows, Barbusse never took the trouble to answer the critics. This may be due to pride. ${ }^{9}$

July, 1917, that his position was first assailed. At that time M. Clemenceau, later French Premier, charged that M. Malvy was spreading "defeatist" propaganda among the troops, and Malvy's resignation of his post as Minister of the Interior was announced early in August. In November, 1917, Malvy introduced in the Chamber of Deputies a bill demanding that he be tried before the high court, and the Chamber appointed a committee of thirty-three to inquire into the merits of the case. This committee submitted its report calling for Malvy's im. peachment. On August 6 , 1918, Malvy was found guilty of holding communication with the enemy and sentenced to five years' banishment. The sentence, however, did not carry with it civic degradation.

9 Concerning the success of the hook in America the situation is about the same as in France, namely, that it is quite possible that German agents helped in advertising $L e F e u$; but Under Fire was published by a 37

$$
\text { (2) } 611=0
$$


The literary historian of the future will have to take into account another fact when he comes to discuss the case of Barbusse. It is that the attitude which he assumes toward the soldier is an effect of his morbid temperament. It was Barbusse, it must be remembered, who a few years before Le Feu, wrote L'Enfer (1908), which is surely as morbid and impure a book as any man might care to handle. There are many ways of expressing views of life which bespeak despair and disgust. Examples of this are afforded by the literatures of all ages, from Buddha and Omar-Khayyam to Leopardi, Schopenhauer, and Baudelaire. But why should Barbusse choose the most repulsive? It seems natural enough that a man of his temperament should write about the heroes of the trenches whom the war had thrust upon his attention, in the same abnormal manner which he had adopted in describing the repulsive, though perhaps real, creatures of his former work. ${ }^{10}$

firm (Dutton) which has shown strong pro-Ally tendencies and could therefore be blamed only for lack of due caution. It was unfortunate that the translation came out just at the time when American public opinion had to decide whether or not America should enter the war; it did not, however, affect the issue.

$10 \mathrm{It}$ is regrettable that, on strength of the success of Le Feu, an American firm should lave recently brought out a translation of L'Enfer (under the title Inferno). 38 
The writer would go even farther. Surely a large part of the responsibility for the regrettable popularity of Le Feu, in France as in this country, rests with the public. It is partly an effect of the modern craze for the sensational, the abnormal, and the morbid. One thinks naturally of a woman as a charming, graceful, kind creature, and one considers it the duty of "real," "true," “original" art, to represent her as willful, masculine, and cruel. The normal idea of a clergyman is that of a conventional, sincere, and honest man, but he becomes "artistically" interesting only when he is represented as unconventional, shrewd, satanic. Likewise, the picture of a soldier which comes first to mind is that of a vigorous, high-minded, heroic fellow, but a book which represents him as shock-

It is still more regrettable that in a somewhat bombastic preface, an American critic should have spoken of Barbusse as one of "the most distinguished contemporary French writers" ("notorious" would have been better), and of L'Enfer as of a "spiritual" book, one through which "a cleansing wind is running." Naïveté has its limits; such judgments would certainly cause French critics to smile. What is more serious, however, in this matter is that the morlid scatology of the work is likely to produce a very false impression, on the American mind, of the type of novel which is weleome by the French public. It is a well known fact that many repulsive novels which have passed as Freneh works, were of German origin, and in the spirit of an insidious propaganda, were intended to dishonor the name of France. 
ingly non-heroic, homesick, and shirking hardships, is regarded as the work of the "original, superior artist"; it would be terribly bourgeois not to accept that distressing picture, and the opportunity is good for one who feels within him the soul of a Philistine to make himself appear a person of superior judgment.

The reader who looks for strong sensations in war literature because he thinks that the terrible and the sickening are inseparable from that kind of literature, need not read Barbusse's Le Feu which leaves so distinctly unpleasant an aftertaste. ${ }^{11}$ There are many others which one might suggest in preference. Let him take up at ran-

11 At the beginning of 1919, Barbusse published another war-novel entitled Clarté (Flammarion), which shows conclusively that he has not paid the slightest attention to all that had been said of his first war book. Indeed, in many ways, it seems to be only a new edition of Le Feu. The hero of the book is one Simon Paulin, a small clerk and a perfect Philistine, who takes life as it comes, allowing himself to be led by society as at present organized without protest or conscious reaction. The war breaks out: he is called to the colors, and answers the call; he then sees and goes through all the horrors pictured in Le Feu and repictured once more in Clarté. As he lies wounded and delirious on the field of battle, the thought comes to him that the people have always been led like eattle. That passivity of the people,-not only in his own country, but in all nations including Germany,-irritates him, and he dreams therefore, of destroying all national emblems and of working towards the establishment of a Republic of the United States of the World. 
dom any of the war diaries which we mention below, and he will not be disappointed. But he will soon notice that although no writers who have had experience of the war, ean eonsistently refrain from speaking of its horrors,-and this is true even of those who like Commandant Henches and the author of Lettres d'un Soldat take up their pen with the deliberate purpose of getting away from the atmosphere of war into that of serene and quieting meditation,-yet there is not one who has sistematically taught that war has no redeeming features; not one who has failed to aeknowledge that the war has brought out beautiful traits in human nature, and that even the humblest soldier participates in that moral uplifting which human suffering brings to every man, however lowly his station in life.

* $\quad * \quad *$

Barbusse, apparently, would have us believe that his language is that of an umprejudieed philosopher. Let us now examine the work of a man who might put forth a similar claim and with better reason; a man who is just as anxious as Barbusse to aroid jingoistie talk. We shall see then what the attitude of an ante-war "in- 
tellectual" can be when he has not the peculiar bent of a Barbusse.

Adrien Bertrand's novel L'Appel du Sol (1916) ${ }^{12}$ will never appeal much to the general public because in addition to magnificent battle scenes-some of which would not suffer by comparison with even such classics as Mérimée's Prise de la Redoute,-it contains long chapters devoted entirely to philosophical discussions. But the reader who is interested in ideas will pronounce L'Appel du Sol superior to any of the three books we have already mentioned.

In some respects it reminds one of $L e F e u$. It is composed with marked artistic care; we mean that its scenes are not mere photographic or gramophonic reproductions of picturesque or telling episodes, but are minutely and exquisitely worked out. The characters, too, are not merely real, they are composed of traits carefully selected and skillfully worked up into consistent unities; and the whole work, like Le Feu, answers thus perfectly to our definition of warfiction, as an artistic rearrangement of facts with a view to bringing out, more vividly than reality, some aspect or other of the war. Like Bar-

12 It was awarded a Prix Goncourt in 1916,--for 1914 when none had been awarded. 


\section{PERIOD OF DOCUMENTATION}

busse again, Bertrand maintains philosophical unity by grouping a few men who present not so much different points of view as different aspeets of the same general point of view. But here we have reached the parting of the ways.

Barbusse has rather narrow soeialist or anarchist inclinations, while Bertrand is an intellectual of a much broader type. IIe does not, under pretext of doing away with all sophistry or hyprocrisy, pick out as sole representatives of the soldiers men of no education whose words are mainly expressions of distress at their material privations or of revolt at the appalling slanghter which arrests in them all thought, and reduces them to the state of passive instruments of war. Bertrand also reproduees the thoughts of the common soldiers, but the words which he quotes, even when the speaker is unedueated, do not suggest an utterly ignoble philosophy. When, for instance, Angielli grumblingly remarks after a fierce battle: "Ce n'est rien de mourir, mais c'est dur de ne pas manger,' his philosophy (and there is a world of it in that short sentence) is by no means of a sordidly matcrialistie kind, nor is his attitude one of surly revolt against the government which demands of him military service. And, as we have elsewhere remarked, one 
can give any coloring to the war philosophy of the common soldiers by the selection which one makes of their reported utterances.

But Bertrand introduces men of culture. They are the officers who are allowed to contribute a large part to the discussion of the problems which the war las raised. And, indeed, why should they not? Why should only the ignorant have a right to speak, as in Barbusse? There is an interesting parallel drawn between the two chief figures among those officers, Lucien Fabre, a very young "Saint-Cyrien," soldier by profession who becomes philosopher by the accident of the war, and Vaissette, "agrégé de Philosophie, ancien normalien et Professeur de lycée," philosopher by profession and soldier by the accident of war. This Vaissette who represents the "intellectual" in the war, Bertrand has portrayed in a masterly way. ${ }^{13}$ And then, there is another clever parallel between Nicolai who has learned warfare in colonial service, and the young man (Fabre) who has acquired his knowledge through courses at Saint-Cyr. These offeers discuss of course chiefly topies related to the

13 Since Bertrand's book, that type has appeared often, either in novels like Marcel Berger's (see below), or, especially, in war-recollections: Rédier, Genevoix, Fribourg, Malherbe, Delvert, etc. 


\section{PERIOD OF DOCUMENTATION}

war; they discuss the soldiers of Marathon, of Cannae, of the First Freneh Republic, of Marignan, or the eourage of the Christian martyrs. Their symposiums take place after or before, and sometimes even during, an encounter. After one of the great battles, our group of philosophers walk to a cemetery, some distance away, to talk over the slaughter that had just taken place. Vaissette especially "was thirsting to exchange ideas with some one in order to make his own ideas elearer to himself"' (p. 70).

It is interesting to notice how, all through the book, Bertrand (who, before the war, had written in a cynieal vein Le Jardin de Priape, and a play, La Première Bérénice) endeavors to maintain an attitude of detaehment, and eagerly seizes upon incidents ealculated to convinee the reader that he is not eheaply yielding to the ever present dramatie note; $\ell . g$., as the squad is about to take part in a dangerous attack in which many men are bound to die, Vaissette, in the course of a discussion why the men are willing to lay down their lives, remarks that they are all "sound asleep"'; the inference being that the determining factor in the momentous decision which they take, is not the moral struggle within them, not the sense of duty to the eountry which demands 


\section{FRENCH LITERATURE OF THE GREAT WAR}

the supreme sacrifice, but their physical fitness or exhaustion at that time. Elsewhere, the discussion brings to light how easily the best and most carefully laid plans may be rendered ineffectual by the accidental interference of some unthought of, and in itself unimportant event, and seems to point to the conclusion that chance is, after all, the ultimate cause of success or of defeat in battle ... Voltaire's "pyrrhonisme de l'histoire." The soldiers do not willingly accept the idea that their readiness to die is not attributable to some purpose clearly realized by them; but when they try, each in his own way, to define that "cause" of their devotion, one feels uneasy in observing that they do not seem to know why they sacrifice their lives; some say that they are fighting because they were attacked, others that it is to win back Alsace-Lorraine, others again that it is to put an end to war itself, or not to be worried again by the Germans, or because France cannot be wrong. Again, it is evidently not by an oversight that Bertrand left without definite conclusion the following discussion between two officers:

"My Voltairian soul has long doubted the existence of God," said Vaissette, "but this war 46 


\section{PERIOD OF DOCUMENTATION}

has helped me to pass from doubt to the eertainty of his non-existence."

"-You would not say, I imagine, that this war is a proof of the triumph of reason in the world ... ?"

This was from Captain le Guéri, who had just joined the group; and the ennversation continued under the serene sky as the Captain added: "You see in the war a condemnation of my ereed [belief in God], and I see in it a condemnation of yours. This war means the bankruptey of reason!... The one thing that is certain is that religion and reason have both proved themselves unequal to the task of preventing this gigantic folly of men, I mean this mad slaughter'” (p. 250-1).

Bertrand goes no further with his argumentation, but the skeptic within him is compelled to yield at last. In the magnificent chapter $P^{\prime} a$ roles avant la Bataille, we notice the first concession of the "intellect" to the moral beauty of the great wave of sacrifice which the world-catastrophe had favored. Although he finds no rational explanation of what he sees, his admiration wrings from him the admission "qu'on peut tout obtenir de l'être humain', (p. 183); and 
that "tout" means heroism and sacrifice. And before we reach the end of the book, we find Bertrand adopting the metaphysical formula, "Ce qui les dirigeait tous, e'était l'appel de la terre française", (p. 245); this is as far as he allows himself to go.

After the last battle described in the book, we see Vaissette dying of his wounds. The philosopher in him is still on his guard lest his intellect be deceived by sentimentality, emotionalism, the hypocrisy of polities, or what not. When, at that supreme hour, he asks the stretcher-bearers for news of his fellow soldiers and officers, and receives in reply to each inquiry the same monotonous and tragic: "killed! . . killed! . . . killed!" his only answer at first is: "And so am I!", But soon his body is shaken by a convulsion, and then, opening his eyes with great effort, he murmurs as he closes them again forever: "But France lives on."

* * * *

A few words ought to be devoted at this point to two belated war novels-of 1919-which are of the same order as the two just discussed.

Barbusse had few disciples; he had some, however, probably the most original of them being 


\section{PERIOD OF DOCUMENTATION}

Léon Werth, who in his Clavel Soldat shows with much brillianey the same spirit of annihilation as regards principles of patriotism, and other bourgeois conceptions of life; moreover, having done all his duty as a soldier, he feels a right to speak and he does not hesitate to say that war is as ugly as anything can be and that there is no need to try and lie about it by telling of the heroisms of all sorts which it engenders. Clavel, who thus wages war on war, has found a volume of Roussean's Confessions in the trenehes, and he reads about the idyll of the Charmettes; he thinks: "this is life indeed"; ... but he fails to refleet that the wal" was fought by the Allies to bring about the possibility of such a life.

The second of those novels is Jean de Granvillier's Le Prix de l'Homme. But both the eontent and the form would rather class it with Bertrand's Appel du Sol. The hero-really the author as well-lieutenant Mignul de Larréguy, is a young man full of ardor who has been longing for something that would make life worth living; he finds the something in the trenehes. That is to say, he comes to the conchusion that there is $n 0$ eondition in this world like war, to 


\section{FRENCH LITERATURE OF THE GREAT WAR}

call forth the best that is in a man. The accounts of actual war experiences are equal to many of the best in the best war books.

The same spirit of enthusiasm for the opportunities of war, with almost a mystic note added to it, is found in Ch. Briand's novel, Le Sang (1919).

* * * *

There is in Marcel Berger's Le Miracle du Feu a delicate love affair interwoven with the account of the first weeks of the war; but the main interest of the work lies in the author's very keen psychological analysis of a soldier's mind. While Gaspard, Bourru de Vauquois, and the men of the squad in Le Feu, are all uneducated men who have sprung from the common people of France, Berger's hero, a sergeant named Michel, like Bertrand's, belongs to the class of the intellectuals. But Vaissette, it will be remembered, had always studied life in the disinterested spirit of a philosopher and theorist; Michel, who is also an educated man, had used his knowledge and refinement for the attainment of purely selfish ends. His attitude when the war breaks out is frankly that of a eynic. He has a good position which affords him plenty of leisure, and he leads a comfortable, un- 
eventful, self-centered life, Emotion he has banished as a disturbing factor; he has remained a bachelor because marriage imposes responsibilities which he does not wish to assume. When he is ealled to the colors, he joins Inis regiment with some reluctance; not, indeed, through any sense of duty, but because by not doing so he would bring trouble upon himself. Once in the army, he is very anxious to avoid all unnecessary work; he is friendly toward his soldiers not by natural inclination, but because it is the best way to avoid trouble; he strongly resists any temptation to be earried away by patriotic sentiments; the first daring deed which he witnesses on the battlefield he explains away: "a man who has no nerves." He watches over himself, is ever mindful of the safe principle: "each for limself in a fray like this"; he even commits ungentlemanly acts, as, for instance, when he stealthily exchanges his leaking canteen for a sound one which he takes from one of his fellow soldiers. But, very gradually, and very slowly, the sight of human suffering around him, the courage displayed by the men, and the genuine kind-heartedness of his humble companions, make him change his attitude; he deeply realizes the tragedies caused by the death of 
heads of families and of recently married men; he is affected by the help that religion will bring to some poor dying fellow; and although he still likes to think of himself as of a superior intellectual being, he is already a changed man. His behavior in the heroic days of the Marne (sector of Ourcq), shows how great has been the change. He is wounded; loses one leg; and for some time, in the hospital where he lies helpless, his old self takes hold of him again; he revolts against life. But the gentle consolation of a loving woman dispels the threatening cloud, and his better self triumphs in the end.

This is certainly one of the most painstaking and thorough products of literature of the war in the form of a conventional novel. It is the best presentation of that theme, moral regeneration through suffering, which has so often been treated since (in novels and in soldiers' diaries, and on the stage) that it has become not only commonplace but almost exasperating at times. This recurrence, however, can certainly be taken as an indication that the war has actually rescued many,-especially among the intellectuals and the artists,-from a life of discontent and gloom; that it has shattered the dreams of some who had set themselves an unat- 


\section{PERIOD OF DOCUMENTATION}

tainable goal, has inspired others who were living aimlessly, and, to all, has offered a definite and beautiful task. ${ }^{14}$

* * * *

One of the most refreshing of the war novels, -and one which the public reeeived with evident pleasure,-is Marcel Nadaud's Chignole ${ }^{15}$ (1917). Chignole is a young Parisian, and,what is more signifieant-a child of Montmart re ; Le Goffie called him appropriately enough, "Gavroche avec des ailes." IIe is intelligent and witty; and, conscions that his versatility rill stand him in good stead in all eireumstances, he never worrics. His philosophy can be expressed in a very few words: "Ne pas s'en faire." From early boyhood he had had a rague interest in mechanies; he therefore went to work in a bicycle shop; later, following the movement of the

14 Berger's book was heavily censored, lut two remarkable passages which were allowed to remain deserve to be pointed out. The first is Berger's definition of the skeptic's attitude towards the war, in a speech which he puts in the mouth of Fortin, one of Michel's fellow solc...ers (pp. 87-94); the other showing the "miracle du feu," in Michel's own words, just hefore a striking description of the offensive of the Marne (pp. 391-395).

${ }^{15} \mathrm{~A}$ chignole is a special type of brace which aviators frequently have oceasion to inse in all kinds of adjustments of their machines. In Nadand's book the word is applied, as a niekname, to a picturesque young aviator on account of his wonderful resourcefulness. 
times, he obtained employment successively in an automobile, and in an aeroplane factory. He was just twenty when the war came with all its splendid opportunities for a youth of his type. The pilote who is supposed to be writing the book has just raised Chignole from the rank of a mechanic (mécano) to that of observer. That means, of course, that Chignole is going to fly; and his enthusiasm, his energy, his taste for all the most extraordinary and foolhardy adventures, make him a figure worthy of the pen of the writer of The Three Musketeers. Chignole is at once wonderfully clever, magnificently heroic, profoundly touching and picturesquely absurd, and retains witlal a delightful childlike simplicity.

Chignole could best be described as the Gaspard of aviation. Although the work was published as late as 1917 ,- $t$ that is the same year as the gloomy Le Feu,-Chignole has the same spirit, the same irrepressible cheerfulness as Benjamin's hero. The explanation lies in the fact that the extraordinary vitality and alertness needed for aviation work kept the men in those units from experiencing the depression to which the men in the trenches fell victims. Every day they played with death, and there- 


\section{PERIOD OF DOCUMENTATION}

fore had no fear of it. Indeed, their foolhardiness won for them the reputation of being, one and all, erazy fellows. ${ }^{16}$

$* \quad * \quad *$

It is not to be wondered at that, after the war had lasted three years, and its men and arms had been eelebrated in many books, the reading public should feel that the theme of the hour, though inexhaustible in itself, might, perhaps, be renewed with advantage by some fresh method of treatment, or by laying stress on some aspeets of the war which had hitherto been neglected. Several writers attempted that renewal. They left the main stream of warlike events in which the real fighting soldiers are winning glory, suffering, conquering and dying, to explore what may be ealled the backwaters of the war: the very necessary, but much less glorious activities behind the lines.

16 Chignole was not Nadaud's first work. Before the war he had written Coups de ciriffe. . . Pattes de Velours, and Tendresses.... Tristesses. He has also recorded his experiences in the Aviation Service in lin plein Vol, Souvenirs de Guerre Aérienne, 1917, a book whieh has had enormous success. More recently still, he has published Les derniers Mousquetaires, and Frangipane et Cie-telling the death of Chignole: and a biography of Guynemer which, however, is much less elaborate than the one written ly Ifenri Pordeaux.

Of the same order as Chignole, is Badigeon, aviateur, by Lieut. G—, pilote (1919). 
Of the two novels we are going to take up here, one deals with a half soldier, an "auxiliaire," the other with a man even farther remote from military activities, a war-reporter-whose very slight comnection with military matters permitted of his being smuggled into a war-novel.

The first is Marcel Berger's Jean Darboise, Auxiliaire $^{1 \tau}$ (1918). It is a very long novel. As we have already had occasion to notice in studying Le Hiracle du Feu, M. Berger has not the gift of brevity. But the work is nevertheless interesting, were it only as a document. Darboise is a soldier who after being wounded at Verdun, has recovered but is not well enough to be sent back to the front; he must therefore join an auxiliary corps. In civil life he was an artist, a designer, and he suffers greatly at being kept at tasks which might just as well be done by the most unskilled laborers. He is sent to Dunkirk, an industrial city and sea port in the North of France: a place absolutely devoid of interest for a man of his mentality, and which, during the war was frequently visited by German raiding aeroplanes. His life there is minutely described

17 Auxiliary troops are composed of men who are phy. sically unfit for duty on the firing line, but who are valid enough for all kinds of fatigue work. 


\section{PERIOD OF DOCUMENTATION}

in all its wretchedness. The barracks are unattractive; he therefore takes some poor lodgings in town; and from morning till evening, for the glory of France, he unloads ships, helps in the making of bread for the army, or does occasional work in some factory or other. It is all dirty, brainless, purely manual work. There is not among his fellow soldiers a single congenial man. They are the dregs of the army, "rien que des faces d'abrutis on de brutes, les deux grandes catégories," and the officers who eommand them are not much better than the men. To a soldier who has known Verdun with all its horrors and perils, but with its tragic beauty too; for a man who has enjoyed the companionship of the splendid troops of Verdun, the situation is well nigh intolerable. After 150 pages, however, the picture is pretty well completed, and we enter then into a regular psyehological novel, or we should say rather into two novels.

The first one is the romance of lis love for his family. One day, it is true, he becomes unfaithful to his wife as a consequence of the demoralizing effect upon him of that deadly dull locality. His wife eannot understand, and they are, for a time, estranged from each other. 


\section{FRENCH LITERATURE OF THE GREAT WAR}

The second is the story of the intense suffering of Darboise's soul. So great indeed are those sufferings, that he can bear them no more and he rebels against his lot and against the military authorities. He is cast into prison from which he is delivered by an attack of pneumonia. In the hospital to which he is taken, he meets a good and kind non-commissioned officer (whose little romance also appears in the book) who saves him from despair and reconciles him with his lot and, later, with his wife.

All things considered, Jean Darboise is a novel of the same type as Le Miracle du Feu. It is the story of the conversion of a snob to a man of courage and worth. But since the conditions under which an "auxiliaire" lives are less inspiring than those of a soldier of the Marne, the final moral victory of Darboise is even greater than that of Michel, the hero of Le Miracle du Feu. Nevertheless the fact remains that Darboise will never inspire the reader with the same interest as Michel. In that respect, he remains the victim of his surroundings; for the description of a dismal manufacturing town in war time can never have the fascination of the relation of battles and of other experiences of a soldier of the first line. Even Jean Darboise of Dunkirk 
compares unfavorably with Jean Darboise of Verdun. ${ }^{18}$

* $\quad * \quad *$

In spite of what has been said,-and even if one takes into account the fact that a war correspondent has necessarily a lesser claim to interest than a soldier on active service-René Benjamin's Le Major Pipe et son Père (1918) is distinctly inferior to Gaspard. A young journalist has shown a little more than contempt for England's part in the war. One day, his duties as war correspondent take him to the British front, and later to England. $\mathrm{He}$ is received with cordiality, nay more, he is treated with consideration, and very soon he is won orer by the solid, comfortable organization of the English

18 If the whole truth is to be told, it must be said that although the "will to live" and to suffer for one's country is the note with which the book eloses, the disquieting thought thrusts itself upon one that the author has inserted his conelusion rather as a matter of duty than of conviction. One cannot help noticing that on page 203 he makes one of his charaeters say in reference to Barbusse's Le Feu: "It is the sineere cry of a man of genius, to which the heart of all France eagerly responded" (un génial cri de sincérité, aecueilli dans toute la France avec un immense soulagement).

P. Coutras has also written a novel of the same gloomy inspiration, Les Tribulations d'un A Axiliaire (1916). The bitterness in the tone of Coutras's book has been traced by some to personal experiences of the author as a "soldat auxiliaire." 
Army and Navy, by the generous British way of doing things, and by the simple, sincere, hearty hospitality which is offered him. When he returns to his own country, not only is he a sincere Anglophile, but he is convinced that he has "discovered"' England. More than that, he develops something which savors of a certain contempt for the treatment which the French government metes out to its soldiers. Those thoughts he communicates privately to his wife.

It must be confessed that Benjamin has yielded a little too readily, in this work, to his taste for satire. It was not necessary that the representative of the French press should be represented as so vain and provincial. A more delicate satire would have been quite as effective-even more so. At the same time, it was a good idea to use that scheme to familiarize the French public-who was even in 1918 in need of enlightenment upon that subject-with some aspects of the organization of the British army as compared with that of the French. ${ }^{19}$

The same criticism would apply to Grandgoujon, a novel published by Benjamin after the close of the war (1919). The adventures and

19 Cf. M. J. Aulneau, A $u$ Front Britannique, Tableaux et récits d'un Observateur (Payot, 1919). 


\section{PERIOD OF DOCUMENTATION}

experiences of that Frenchman of forty, who does not know very well whether he is in or out of the army, is more the caricature of a type than a real type.

* * *

We would go far beyond the limits we have set ourselves if we were to deal at any length with the numerous volumes of short stories in which types of soldiers are sketehed-most of the time by soldiers themselves. But we ought to mention, by title at least, some of the best collections, as Claude Farrère: Histoires de Quatorze Soldats; H. Bordeaux: Jeunesse Nouvelle; Contes Véridiques des tranchées, par un groupe de Poilus; Nouveaux Contes Téridiques, by the same, and a third collection, Sous l'Obus; Les As peints par eux-mêmes; since the war (1919), the remarkable volume by Vignaud, Les Sauveurs du Monde "contes suggérés par d'horribles visions"; A. Arnoux, Le Cabaret.

One special word about Pawlowski's Signaux à l'Ennemi (1918). ${ }^{20}$

Cleverly illustrated by Gus Bofa, this little volume of 225 pages has an originality all its own. It is a collection of very simple stories, the

20 For Pawlowski's other works, see chapter III, section 3. 
atmosphere of which has every appearance of being more genuinely "poilu" than that of any other book that has come under our notice. The pictures which the stories present are certainly most "plausible," and, if one may be allowed to use once more that much abused word, thoroughly "human:" The principal story (which gives its title to the collection) is an amusing account of the excitement caused in a cantonment on the firing line, by the strong suspicion that a spy signals to the enemy whenever one of the men go up into an observation tower. Who is the spy? Finally, but not before one of the men has been arrested as a suspect, it turns out that each time that some one goes up into the tower, a number of frightened crows take their flight from the roof into the open sky, and the Germans have need of no other signal to inform them that it is time to make a target of the tower.

\section{War Recollections and Diaries}

\section{INTRODUCTORY}

If Bacon's definition ars homo naturae additus be accepted, the war diary must be admitted to rank much lower as a literary genre than the war novel. Its artistic inferiority, however, 
does not deprive the war diary of its title to be regarded as the most eharacteristie li.erary produet of the war, and the most trustworthy source of information regarding certain aspeets of it.

War literature, as we have already said, like the war itself whieh gave it birth, is something exeeptional, abnormal; and as Balzae has pointed out in his preface to La Comédie IIumaine, nature, espeeially in times of great crises, is vastly more prolific of what we regard as extraordinary situations, than the most vivid imagination of any man eould ever be.

The soldiers who saw some part of the war, and who were able to handle a pen, realized that truth and acted aceordingly. Their manner of recording their experiences is not, of eourse, uniform, but the very large number of volumes of war recolleetions is evidenee enough to show that the natural tendeney of writers was to "reeord" their war experienees rather than to "re-create" them in the interests of art. Moreover, writers took it for granted not only that they might, but that they should speak in the first person; it was indeed important that the "ego" of the soldier of 1914 should be revealed with as little artistic draping as possible; 
far fom marking any lack of modesty, that simple self-revelation betrays rather a genuine desire to be as truthful as possible; again most of those recollections are less those of individuals than of groups of individuals; they are, as it were, impersonal recollections. As to the reader, the times were too serious, the subject too important for him to be satisfied with anything less than the whole truth; he would have resented as an act of bad faith any partial concealment of the soldier's "reactions", whether good or bad, whether heroic or disheartened. And now if the picture which we obtain from a perusal of those war recollections is on the whole a bright one, that brightness must be attributed to the inspiration which the men received from their intense patriotism and from the consciousness of the justice of their cause.

France produced during the war an ample and beautiful harvest of war recollections. In this she was faithful to her ancient traditions, for it was from France that, at the dawn of Modern Civilization, came those first and fairest of epic poems which bore as their motto: Gesta Dei per Francos; and in subsequent centuries, France has counted among her most famous cap64 


\section{PERIOD OF DOCUMENTATION}

tains men who also took rank among her most famous writers; the old classic Brantôme, Agrippa d'Aubigné, La Rochefoneauld, de Retz, Marbot, Stendhal and others, to say nothing of men like Ronsard, Honoré d 'Urfé, and Descartes, who, although they did not write on military matters, had wielded the sword before they took up the pen.

$$
\text { * } \quad * \quad *
$$

Among the military writers of the past, there is one who has appealed particularly to the soldiers of the present war, and whose works, we are told, have been read more than those of any others in the trenches (for the French soldiers did a great deal of reading in the trenches)-Alfred de Vigny. This popularity of Vigny was due not only to the fact that he was a shining light during one of the brilliant periods of French literature, but because in his classie Servitude et Grandeur Wilitaires (1836), he had approaehed in a remarkably modern spirit all the great problems whieh the war has again thrust upon the attention of thinking men; such, for instance, as the questions whether the idea of a citizen army as opposed to a mercenary army is utopian; whether war is to last 
forever or whether peace can be made to do so; and questions relative to the nature of patriotism, of military honor, etc.

* * * $\quad *$

The first of these topics,-citizen armies,had been foremost in the minds of French officers for several years before the war. The first time since Vigny's days that the subject had been presented to the French reading public in such a manner as to create a deep impression, was in Pingot et moi (1893), a very remarkable work by Art Roë. ${ }^{21}$

Pingot et moi immediately established the author's reputation as an authoritative writer on military topics. And Art Roë himself attributes his military writings to the inspiration of Vigny's little book. He reminds us how clearly Vigny had stated the great problem which confronts all governments in this democratic age, when he wrote on the morrow of the French Revolution: “On ne peut trop hâter l'époque où les armées seront identifiées à la nation, si elle doit acheminer au temps où les armées ne seront plus, et où le globe ne portera plus qu'une

21 Art Roë (pseudonym for Patrice Mahon) was born at Lons-le-Saulnier, Jura, in 1865; he was a lieutenant in the French army when Pingot et moi appeared. 


\section{PERIOD OF DOCUMENTATION}

nation unanime enfin sur les formes sociales"; and, after inquiring what has been done sinee 1870 to re-form and re-ereate the army, he concludes: "Le voeu d'Alfred de Vigny est aceompli; notre armée n'est plus que la nation en armes."

Indeed it would be diffienlt for any one truly to understand the modern Freneh army, the army that fonght the Great War, without reading Art Roë. The admirable spirit of eoöperation of chiefs and soldiers, which has been so often and apparently so justly praised since 1914, finds its explanation in Art Roë's works. It is that coopperation which differentiates the French army not only from the German in which the human riglits of the individual soldier seem so much negleeted, but, to a very large extent from the British army also, if the reports of many Americans who have had opportunities of observing conditions during the war are to be trusted. And this aehievement is the result of mueh arduous, consistent and sustained thought and effort. The title Pingot et moi is a program in itself. Pingot is the orderly of the lientenant who relates the story; he is a good fellow "aux bons grands yenx homnêtes, anx lèvres volontiers souriantes"; he is moreover an exeellent soldier. 
Pingot is well treated by his superior who understands that he is not a professional soldier and not a "mercenary," but a man who has been torn away from civilian life. In return for that human sympathy, Pingot shows himself a devoted servant, ever ready to do anything that his chief desires him to do. He enjoys nothing more than to be allowed to carry out an order in his own way, and thus he develops a very good spirit of initiative. The book does honor to the great heart of the man who wrote it. Art Roë takes up the same problem in his second book: Mon Régiment Russe (1899). He is sent on a mission to study the Russian army, and is interested to find how the famous general Dragomirov has solved the problem of developing the soldier without suppressing the man. "Où trouver un système d'éducation militaire respectueux de la personne humaine et qui tende à accroître l'homme en l'homme?', (p. 166). It will be seen from this that the problem, as understood by our author, is not merely that of not harming the man during the process of making a soldier of him; he wants the officers to handle the training in such a manner that it will actually have been of advantage to the man later on when he returns to civilian life. There are in- 


\section{PERIOD OF DOCUMENTATION}

tensely interesting passages in Roë's seeond book; that, for instance, in which he says that Dragomirov's work in the Russian barracks brought back to his mind a certain passage of the Gospel: "Je me suis souvenu de cette parole du Christ: qui donne son âme pour l'amour de moi, la retrouvera"' (р. 181).22

The importance of Art Roë's work eannot be exaggerated. Pingot ct moi is the common ancestor of those officers' diaries which, together with the diaries of the private soldiers, are our most important sources of documentation on the army's part in the war. During the twenty-one years that elapsed between the publication of Pingot et moi and 1914, quite a number of officers had succeeded in interesting the public in their recollections and in their years of service in the colonies. Baratier's Epopées Africaines (author killed at Verdun) and Capitaine Cor-

22 The problem of the Russian officers is very different from that of the French. Art Rö̈ has expressed that difference in the following manner: The Russian officer has to develop the personality of the soldier by drawing it out of the Russian mass, while our problem in France consists in the making of a compact, tightly kinit, homogeneous mass out of elements which are distinct and strongly individualistic (p. 362). In both countries the end in view is the same: that, namely, of forming an army. 
FRENCH LITERATURE OF THE GREAT WAR

net's La Conquête du Maroc are two of the best knowu publications of that kind.

* * * *

Two other works, written by much younger officers, and dealing with the psychology and philosophy of military life, were attracting a great deal of attention on the eve of the war. The first is Psichari's L'Appel des Armes (1913). which, although it is presented in the form of a novel, is nevertheless full of personal recollections. The mystic note of those pages, in which the author exalts the profession of the soldier to the point of saying "War is divine," is very striking. ${ }^{23}$ The other is Nolly's Gens de Guerre du Maroc (1913) ${ }^{24}$ which is, all told, a more sober, and also a more solid work; and one which will probably replace Psichari's Appel des Armes in the memory of men. Nolly is the more direct continuator of the work of Art Roë. His sympathetic study of the French soldier is remarkably relevant, objective and keen. There was absolute certainty in his mind after 1911, that war could not be averted, but his confidence

23 This mystic note is even stronger in a posthumous novel of Psichari's, La Veillée du Centurion, published at the end of 1914 .

24 Nolly is Capitaine d'Etanger's nom de plume. 


\section{PERIOD OF DOCLMENTATION}

in the sterling qualities of the army in which he was serving was no less absolute.

"To those who know not the worth of the sword of Franee because they have not seen it thrust and slash; to those who timidly waver, we say: We have seen it, and we know. Take heart! We have tried the force which you entrusted to our eare, and we rouch for its high excellence. Somc day it will work wonders in order that the home of beauty and of good may abide forever. . . . Lift up your heads!'

No propheeies eoncerning the war have received such astonishing confirmation from the cvents as those of Nolly's Gens de Guerre du Maroc. ${ }^{25}$.

\section{Philosophical Type-First Phase}

The three men whom we have just mentioned died very early in the war: Patrice Mahon (Art Roë), who was then a lieutenant colonel, fell at Sainte-Marie-des-Mines, in the Vosges, on August 22nd, 1914; Psichari was killed the same

25 For a detailed study of Psichari's and Nolly's prewar writings, and other pre-war literature dealing with the war, the reader is referred to our study of "Le Roman Militaire en France de 1870 a 1914" (Publica. tions of the Modcrn Language Association of America, March 1919). 
day during the great retreat to the Marne, and Nolly after being first wounded on August 10, and again on the 31st of the same month, died on September 3rd. They wrote nothing, therefore, regarding the war itself; but there were many others who, at that time, were ready to continue their work with pen as well as with sword.

One of the first of the diaries to appear was Paul Lintier's Avec une batterie de 75, Ma Pièce. Souvenirs d'un Cannonier de 1914 (1915). This work was at once recognized as one of exceptional and lasting value, as may be judged by the fact that it ran through 53 editions before the end of the war. Its author was promptly awarded the Prix Monthyon by the French Academy.

Paul Lintier was born in 1893 . He was therefore only 21 when he wrote Ma Pièce. After being trained for a business career, he decided to take up law, and while still in his teens began to write. In 1912, he was enrolled in the 44th regiment of Artillery and was made a quartermaster in 1914. He was severely wounded on September 22nd, 1914, but recovered and returned to the front as lieutenant in July, 1915. He was killed at Jeandelincourt, in March, 1916. 


\section{PERIOD OF DOCLMENTATION}

The freshness of impressions is what distinguishes his book from all others of the same kind, for it was written before the intense emotions of the first hours of the war had had time to subside. It is indeed remarkable how, in later writers, a familiarity of even a very few weeks with the events of the war suffieed to dull the keen edge of their sensibility, so that impressions were reeeived and registered with less eonsciousness of horror, admiration or enthusiasm. ${ }^{26}$ But in Ma Pièce we still have the full vibration of a young soldier's whole being; and because that "being" is a noble instrument, we are absolutely thrilled as he deseribes that first battle (pp. 75-88) with its first dead; those first eries and moans of the first wounded; the tragic suddemmess of the adjustment which the men had to make to new eonditions when they passed without transition on that first morning, from the enjoyment of the peaceful eountryside and quiet villages through which they had marched, to the roaring of guns right ahead of them, and to the sight of burning houses and long trains of distressed fugitives. ... And, the next day, when

26 That remark is true even of Lintier's second hook which is a sequel to II Piece: viz.. Le Tube 1.3.3.3, Son. venirs d'un Chef de Pièee, published after his death by Plon, 1915-1916. 
the men were running their " 75 " into position, they heard the forlorn cry of a little girl, alone and lost in that hell: cries of "Maman! maman!"' and they were distraught with grief because they had to go by, and might not stop to comfort the child (pp. 168-169) ... Then it was the retreat day after day, that long retreat in which they were never beaten but never allowed to make a stand; and it was the physical exhaustion, and the need of sleep, and the demoralization due to days of incessant rain, and the ghastly sight of long trains of wounded, and the fixed idea, in the minds of some of the men, that they were betrayed by their chiefs. . . And then, at last, it was the order to stop on the Marne, and the wave of superhuman strength that came upon the men (p. 209) ... But then, again, there came the vast fields of slaughter, and the harrowing tales, in the liberated villages, of the savage outrages of the Huns (how they deserved the name!) so that when some one in the battery suggested that the war miglit last three months, he was greeted by an angry ; "Three months! but long before that we shall all be crevés de misère."

And nevertheless the "misery" lasted for four years and a half! 


\section{PERIOD OF DOCCMENTATION}

Let us quote this one passage (p. 166):

"Ah! if I survive this heeatomb, how well I shall know how to live! I had never thought that there was joy in the mere facts of breathing, of opening one's eyes to the morning light, of absorbing it, of feeling warm or cold, or even of suffering. I thought that only certain hours in life were worth living, and I let the others go by. If I should see the end of this war, I shall know how to detain each passing hour; I shall make it a point to get out of each second of life every sensation that it ean yield; and it will be to me like the feeling of delightfully cool water passing through my fingers.

"It seems to me that I shall stop then at any time, intermut a sentence, stay a gesture, just to repeat to myself: 'I am alive!... I am alive!...',

The young officer who wrote that did not live; neither did nearly two million of his eountrymen who surely felt as he did, although they had not his powers of expression.

$$
\text { * * * }
$$

Mauriee Genevoix's Sous Verdun, Août 1914, with a preface by E. Lavisse, (1915), was published shortly after Lintier's Ma Pièce. ${ }^{27}$ Gene-

27 The reader will not, of course, expect to find in this 
voix's talent is equal to that of Lintier; he lacks, however, Lintier's spontaneousness; but being a more practiced writer, he compensates by his consummate skill in working up his material, for the relative lack of the direct presentation of immediate reactions. Moreover, Genevoix relieves by occasional flashes of healthy humor the depressing gloom of the picture of war. He relates many episodes in which cheerfulness gets the better of exhaustion, hunger, suffering of all kinds, when the men heroically make light of the most searching and painful tests of their endurance; and we must bear in mind that this was at a time when they were not yet hardened to their new ife; when they were still keenly conscious of the horrors of the war; when lying wounded on the field they would still yield occasionally to despair, crying out for their mothers, or imploring the stretcherbearers to remove them from the field, or to kill them at once. Genevoix gives us also the bright picture of a noble comradeship between two offcers, men of very different types: the Normalien Genevoix and the Saint Cyrien Porchon. The general idea which the book brings out-that book a description of the great battle of Verdun, for this began only in February, 1916. 


\section{PERIOD OF DOCLMENTATION}

war, with all its hardships and eruelties, calls forth manifestations of beautiful traits in human character, and leads at timess to a noble moral exaltation,-is perhaps best summed up in the naïve language of honest Pannechon, the author's orderly: "War is not so simple a matter as one would have thought at first. There are some good things in it, and there are some bad. There are espeeially bad things... though, of course, one comes across some good ones. Only, the bad, in war is first-class bad; it is terrible, I would like to say . . .; and that is why a little bit of pleasure is enough at times to bring back to you a taste for life. One feels that one eould not stand suffering all the time. One must nurse one's strength, for, after all, one hasn't so mueh of it that one ean afford to waste it. We are only men, aren't we, Sir?"

We may remark here that as the war proceeded, the eheerful note grew fainter and fainter in the volumes of war recollections; humor either lost its lightness and became grim, or it disappeared altogether in the same manner as we have already noticed it gradually disappear as we passed from Gaspard to Bourru, and from Bourru to Le F'eu.

The last words of the book inform us that 
Lieutenant Genevoix is about to leave for another sector: Les Eparges. That word is sufficient, for it is full of terrible associations. It was there that his friend Porchon was killed February 20th, 1915. If the reader wishes to follow the author in his later war experiences, he should read his Nuits de Guerre (1917), and Au Seuil des Guitounes (1918).

* * *

Another early war book which met with immediate success was the correspondence published anonymously ${ }^{28}$ under the title Lettres d'un Soldat, Août 1914-Avril 1915, to which André Chevrillon contributes a preface (1915). Many of the letters had previously appeared in the Revue de Paris. They are those of a young soldier who after eight months and one day of warfare, "did not return from an attack." He was an artist in eivilian life; and all his inclinations, all his education, all his aims in life, were diametrically opposed to that which the war demanded of him; and these pages which he addresses to his aged mother reveal in what spirit

28 The author is said to be Eugène Emmanuel Lemercier, who had earned before the war an enviable reputation as an artist. Cf. E. E. Lemercier, Peintures, Dessins et Croquis, with a preface by Andre Michel, Chapelot, 1919. 


\section{PERIOD OF DOCUMENTATION}

he accepted the task which was imposed upon him.

Though evidently frail in body, he is magnificent in moral strength. All his energy is gathered up in an effort to resist the temptation to moral relaxation in the midst of physical fatigue. He must be very exhausted indeed to fail to send home at least a short note whenever the opportunity presents itself; and he keeps constantly in touch, by his reading, with the great minds of the world: Spinoza, Verlaine, A. Franee and the Song of Roland. He remembers musie with pleasure, not excepting German musie. André Chevrillon pertinently remarks in his preface that it was also during wartime that Mareus Aurelius wrote his immortal Meditations.

While Lintier. moves us by the relation of striking war episodes, the anonymous author of the Letters moves us by his determined effort to get away from the somber realities of the war whenever he is off duty, and to re-temper his soul by eontact with what is neither low, nor unelean, nor terrible, "J'ai élevé mon âme à une hauteur où les évènements n'ont pas eu prise sur elle" (p. 23). And for a long time, this artist, surrounded by what is repulsive, ugly, 


\section{FRENCH LITERATURE OF THE GREAT WAR}

revolting, triumphantly struggles: "Take courage," he says to himself, "this, after all, is a question of adaptation: a test of our higher nature. ... I have made resolute vows to remain always in communion with God"' (p. 27).

He neglects no opportunity of admiring nature, which remains ever serene and beautiful. It is remarkable, indeed, how often, in the midst of the horrors which must have been harrowing to a soul so delicate and refined, the word beauty comes under his pen. He clings to beauty, and where it is not, his painter's imagination creates it for him. Once, when a severe bombardment had driven his squad underground, and kept it there for several hours, he catches sight, through the narrow opening by which the dug-out received ventilation, of a "beautiful tree" outlined against the sky, the sight of which brings him comfort and renews his strength. . . . "Do not think that I am indifferent to the awful sadness of the sights which at all times surround us . . . that sadness is the very reason for which I cling to the higher consolation" [beauty] (p. 52). "The beauty of the snow was deeply moving" (p. 114) . . . "Мy heart was strengthened by triumphant beauty" (p. 119). "There are hours of such beauty that those who see it, 


\section{PERIOD OF DOCLMENTATION}

are, for the time, immme to death" (p. 121) .. " "the unspeakable banty of certain sights" (p. 122). And beauty, again, is the last word which he uses in writing to his mother on that sixth day of April, 1915, a few homrs before he was reported missing, just before the lamnehing of an attack the hazards of which he fully realized: "Whatever happens, life will not have been without its beauty" (p. 164).

It would probably be diffienlt to find in any book a more eonvincing demonstration of how suffering brings out the noblest qualities of man. And our anonymons artist knows it and he is profoundly grateful for the intense suffering whieh taught him to know his better self: "It is paradoxieal, as you say, but I have just lived the most beautiful hours of my moral life. . . . Be assured that there will always be beanty on earth, and that man will never be wicked enongl to stamp it out.... I have gathered enough experiences to fill a whole life. May destiny only give me time to bring all that I have gathered to fruition. . . . There is one thing that no one can take away from us, it is the treasure of the soul which we have won" (p. 19). He expresses sentiments which, in their loftiness, are truly Christian: "Tell MI- that if fate strikes the 
best, it is not unjust: the wicked who survive will be made better thereby" (p. 23).

It seems, therefore, sad beyond expression that this noble, energetic soul, after months of intense physical suffering, should be made to feel that moral heroism has its limits after all. He manfully refuses to acknowledge it to himself, but the hour comes when the pressure put upon him is too great, and, reading between the lines, we see that his strength is waning: "Dear Mother," he writes, "after weeping tears of revolt [against the 'atrociousness of the situation'], to which I have yielded all these days, I am again able to say: Thy will be done! yes, I am regaining composure" (pp. 128-129); and again: "How comes it to pass that such horrors should be?"' (p. 137) and yet again, after telling her, in order to give her pleasure, that he is to be promoted to the rank of sergeant, and that he has been commended for conspicuous bravery: "But, dear Mother, how long the war has lasted! too Iong, indeed, for such as felt that they surely had a mission in life. . . Will they not withdraw me from here so that I may accomplish something elsewhere? Why should I be sacrificed while others who have not my gifts are in safety? I had something to accomplish which 


\section{PERIOD OF DOCUMENTATION}

was worth while, but since it is not the will of God that the eup be withdrawn, then, His will be done!'” (p. 139). No one who realizes the intense moral anguish that this sensitive nature had to endure, will blame him thongh he allowed himself to pen the following sentences at the close of a battle: "Our losses have been frightful; those of the enemy, worse. You cannot imagine, Mother dear, what man is eapable of doing to his fellow man. For five days, now, my boots have been greasy with human brains; when I walk, I erush in ehests; I am now looking upon seattered bowels; our men lean against corpses to eat their seanty rations. The regiment has behaved heroieally. We have lost all our officers. They all died gallantly. Two good friends of mine are among the dead. One of them had sat for one of $m y$ last portraits. ... I diseovered his body on the battlefield that night; white and magnificent under the moonlight. I sat beside him for a while. The beauty of things reawoke within me after a time. . . . At last, after five days of horror, we have been withdrawn from that seene of abominations. Duty, effort"' (pp. 135-136).

That man, so gentle, so refined and generous, long refrained from any reference to his feeling 
with regard to the Germans. He liked some of their writers, and admired their music. But at last he is driven to admit: "Unfortunately, this contact with the German race has spoiled forever my opinion of it" (p. 147). Early in the war, his indignation had once shown itself. Commenting on the German practice of forcing French hostages to march in front of their advancing columns, he had written: "If these notes should be read by any one, may they arouse in honest hearts a feeling of horror at the foul crime of those responsible for the war. There will never be enough glory to cover all this blood and shame" (p. 16).

We feel that we ought here to mention, although very briefly, a book which in some respects may be regarded as a companion volume to Lettres d'un Soldat: Major J. S. Henches' A l'Ecole de la Guerre, Lettres d'un Artilleur, Aout 1914-Octobre 1916 (1918). ${ }^{29}$ It affords painful reading, for although Henches is a professional soldier, the war with its attendant evils

29 Major Henches was killed in the Somme sector October 16, 1916. He had four times been commended for bravery. He had specialized in anti-aircraft gunnery and believed that the Zeppelin raids on Paris could have been prevented. 


\section{PERIOD OF DOCLNENTATION}

is a souree of intolerable suffering to him. He declares himself incapable of grasping the immensity of the senselessness which precipitated the conflict. His words are not inspired by anger, but rather by poignant, crushing grief. His only hope is that the horrors of the war will open the eyes of nem and will serve to bring about a permanent peace.

But he is a real stoic nevertheless. IIs courage is equal to every trial. Tery quietly, and with never a word of eomplaint abont his lot, but with great admiration and ssmpathy for his men, he goes abont his work. His mit is sometimes kept in action during eight long eonsecutive days from four o'clock in the morning till eight in the evening, yet they never falter.

What he prizes even more than the splentid showing of the army, is that France, as a nation, has arisen in arms, and has gone forward in a fine unity of spirit.

We find repeated here the experiences of the author of Lettres d'un Soldat. As the war goes on, Henehes' abhorrenee of the Germans increases:

"There are eases like the one of the infantryman whose wife has written telling him that she is big with ehild as the result of having been 


\section{FRENCH LITERATURE OF THE GREAT WAR}

forced by a German, and asking him what she must do: whether she should commit suicide or whether she may live. . . . It is possible to forgive arson; one may account for murder by anger, by fatigue, by a prolongation of the frenzy of battle; but there is no absolution for rape. ... They had hoped in their pride and cowardice that they would meet with no resistance. . . . I shall never, so long as I live, be able to suffer a German in my presence: they are all guilty! That is the worst of war: it scatters seeds of hatred" (p. 40).

"Are the Germans still to be regarded as human beings?" Henches himself has ceased to do so ; but he hardly knows what his feelings towards them should be: "What seems to me stranger still, is that I remember distinctly that in the inferno of battle, I felt no hatred toward the adversary. It seemed to me as a struggle against a blind, brutal force in the reducing of which that war machine, the gun, could alone be of use, there seemed to be no call whatever for any kind of sentiment" (p. 49). This idea occurs in several war-diaries.

How one can remain "neutral" is more than he can understand: "The sinking of the Lusitania has filled me with horror. I am wondering 


\section{PERIOD OF DOCLMENTATION}

what is the matter, mentally and morally, with those nations which do not rise up to destroy a power capable of such atrocities" (p. 70).

And this Aristides, this just man, places on record his appreciation of the attitude of the Pope: "I have read that the Pope, in the interests of religion, has refused to make any pronouneement upon the justice of the eause of the belligerents. As if religion lad anything to gain by courting immoral beings. What eowardice! What an insult to Christ!' (p. 46). ${ }^{30}$

* * *

The next book which deserves to arrest attention is Lieutenant A. Rédier's Méditations dans la Tranchée (1916). ${ }^{31}$ It was written by a young philosopher during the long dreary hours in the trenehes. There was no lack of time, then, for thinking, for elassifying one's thoughts, for deepening them. Rédier is a man endowed with the loftiest qualities of soul, and with a mind which predisposed lim to draw from the war the highest teaching that it ean yield. He is, of all the writers upon the war, the most direet sueeessor of Alfred de Vigny. The title

30 Henches' remarks upon Romain Rolland are quoted elsewhere (end of Chapter I).

31 Crowned by the French Academy. 
which he gave to his work is significant. The Meditations in the Trenches are upon such topics as Duty, Freedom, Glory, Power, the God of Battles, Courage, Honor, Patriotism. . . . His chief interest is the discovery of what moral good France can derive from the war, to compensate in some degree for its abominations. He finds that all is not loss; that the war has served already to remind the French of their indebtedness to the founders of their present civilization; "In reviving former hatreds, the enemy has forced us to think more of our dead and to get into touch again with our past as far back as the days of Joan of Are and of Saint Louis." Then the war has tanght the French the better to appreciate their own people: the brilliant educated classes, and also the so-called lower classes, those morally magnificent men who form the bulk of the army. He protests against the term "poilu" as uncomplimentary, because wit, alertness, fine understanding are the distinguishing qualities of the soldiers of the Great War. Further, Rédier emphasizes, as many others have done, of course, the remarkable fraternity of feeling existing between officers and men: they are really "Brothers in Arms." (In this he shows himself a follower of Art Roë and of 
Nolly rather than of Alfred de Vigny.) In his meditation upon Power, he develops the idea which he states at the begimning of the chapter: "that the war reminds us that Power is a virtue."

One thought preoceupies him more than any other; it is the thonght of death, and we find it expressed on the very first page of the volume. "I wanted to-night during my watch, to keep my mind awake. I therefore meditated upon death, and henee upon duty. I could have meditated upon glory, but I wished not to be dazzled by words. We are exposed here every minute to a death which is glorious, it is true, but which is nevertheless death." What is the meaning of "dying on the field of honor"? The answer is offered him by a soldier who lies dying in great pain, his mind filled with thoughts of wife and children: "The heroism of that soldier consisted in the acceptanee with resignation of his destiny" (i. e. death). This is all that we need say. The slacker who lides in some office at the rear is "luarassed by the fear" of death," while the men who seek a glorious death,-and there are many such,-are after all merely satisfying a personal aspiration. That kind of death is not the noblest. The death that 
counts is that which is suffered "for duty's sake." The soldier must discipline himself to serve some higher purpose. ${ }^{32}$ To accept this moral discipline is of paramount importance: "The first fruits of this slaughter will be a knowledge of, and a taste for, our duties. . . ." "We used to seek for what life had to offer us in the way of pleasure; and we consumed our strength in the quest for comfort and wellbeing", (p. 8). There is nothing noble in that.

Returning to the same subject in another chapter, he tries to be even more explicit: "To what purpose shall we turn this diseipline? To the acquiring of more freedom?-No, for we had too much freedom already; we were cursed with freedom. We were free to make what use we thought fit of our lives, but we were slaves to our comfort and to our habits. ${ }^{33}$ We ought never to have forgotten that all men are dependent upon other men, or laws, or cireumstances of all sorts." "It is not a question of freedom but of order" (p. 53). "We should not, however, go to the

32 In another chapter, however, Rédier pays homage to those who die for glory: "All do not fight for distinctions and medals; but all admire those who do; and it is right that they should: how many there are who have less exalted aims in life!"

${ }^{33}$ This idea will be taken up again by Duhamel who gives it much fuller development (see below). 


\section{PERIOD OF DOCUMENTATION}

other extreme: the ehoice lies between French discipline-not freedom-and German tỵamny", (p. 52). "If France profits by the war, it will be through a mental uplifting, by setting its heart upon other things than its traditional pursuits" (p. 58). That is what must be achieved. "Since 1914, mine French Departments have been paying a heary price, in the form of cmel slavery, because we freed ourselves of our obligation to cultivate order and discipline during the last forty years"' (p. 59). ${ }^{34}$

The idea that the war might teach the French, who are so picturesquely individualistic, a lesson on the wholesomeness of discipline, is coustantly recurring in war books. And no thoughtful person was surprised to see the same theme repeatedly taken up in America when the American youth were subjected to army discipline.

Indeed, the value of army training, apart from any use that may be made of it in actual war, lies in the mental training which it affords. This had, moreover, been emphasized by officers long before the war, and particularly by Art Roë who in 1893, in Pingot et Moi, had made the

34 The author develops similar ideas later in his novel Le Capitaine (1919). 


\section{FRENCH LITERATURE OF THE GREAT WAR}

following statement: "Military discipline, once accepted, becomes the law of a nobler life, and leaves behind it that very Carthusian discipline which Paseal opposes to it"' (pp. 79-80). That comparison of the part played by the Army in teaching self-eontrol with that which is played by the Chureh, is not to be eonsidered as a passing fancy on the part of Roë; he is speaking. with knowledge and deliberation. He fully acknowledges the importance of the influenee of the Church on the life of the nation, but he thinks that it is insufficient at times. Referring to the days after 1871, when the Church had lost so much of its prestige by having east in her lot with the Second Empire (which had led France to Sedan) he bluntly asks: "What was it, then, that saved France from impending ruin? I say that it was the army!"' (p. 94). Many people have been inelined to think that the alliance of Chureh and Army was one of worldly interests only, but it would probably not be very hard to prove that this principle of mental discipline which is common to both institutions is the deeper reason of that allianee. It may be more than mere chanee, and something altogether apart from theological beliefs, that Joffre and Foch and Castelnau and other great chiefs of 


\section{PERIOD OF DOCLMENTATION}

the allied armies should be faithful Catholies.

It was again that eonseiousness of the cooperation of Chureh and Army which directed that perfeetly independent thinker, Adrien Bertrand, in his Appel du Sol (which we have already disenssed) to put in the mouth of the Catholie Captain de Guéri the following words: "I weleome this war. Our country was in need of it: for everything at home was freedom, disorder and anarchy. The pursuit of the war and the government of the State show how necessary it is that we should have order, discipline and authority. The Germans had learned from our fathers the value of these things; and therefore their eountry, where William II is as absolute as our Louis XIV was in his day, plays in Europe to-day, the part which France did in the seventeenth eentury. To wield power as it should, a state must be as orderly as the gardens of Versailles. Nothing is permanent which has not been eonsciously weighed. The Germans aeeepted that limitation of their liberties, with the result that they have been marvelous organizers, as we were in the past, as were the Romans whose sons we are. . . And if their powerful organization does not bring them vietory, it is because they are not yet suffieiently eirilized. They are 
FRENCH LITERATURE OF THE GREAT WAR

still nothing but barbarians. . . They have not yet been sufficiently fashioned by the idea. . . . They are not really pious" (pp. 142-3).

* * * *

We have stated in the Preface of this work why it was necessary for us to limit our studies to a few books which must represent whole classes of similar works. We shall therefore cast only a cursory glance at two others belonging to this group.

The first is Lieutenant Marcel Etévé's Lettres d'un Combattant, Août 1914-Juillet 1916 (1917). This very young man, a student of the Ecole Normale, started as a recruit, and died as a lieutenant in an action so brilliant that it was mentioned in army orders. ${ }^{35}$

Etévé was one of those innumerable Frenchmen who are gifted in all sorts of ways; his pages remind one of the Lettres d'un Soldat. Like the anonymous author of the Lettres, he addresses his mother; like him also, he finds in music and in art a relief from the long nightmare of the war; and he too-although his style is not uniformly grave, being occasionally even quite picturesque and outspoken-finds at times

35 Three quarters of the company, including all com. missioned and non-commissioned officers, were killed. 
that the strain is "too much for human reason": "Blessed are those who have 'got their billet' [les zigouillés] for their troubles are at an end!'”; and to avoid being overwhelned with despair, he takes refuge in the army order "not to try to understand." Noreover, in his inmost soul, he knows that he is fighting to put an end to war, and he feels that if he escapes with his life, he will have a right to be a pacifist. ${ }^{36}$

The other book that must be at least briefly referred to is Dr. Emile François Julia 's La Mort du Soldat (Perrin, 1918). As days of warfare are added to days, and months to months, and years to years, the admiration of this soldier, who is also a thinker, goes less to the great generals and strategists at the rear, and more and more to the men in the field, and to the officers who aceompany them: to the fighting soldiers, the "soldats soldatants." Those are the ones who aet; their thinking is not deep, but it is adequate: "as for us we do our duty, that's all" (Nous autres, on fait son devoir, voilà tout).

36 Eteve snent much of his spare time in reading, and some of his literary appreciations are interesting. For instance, although he is very far from being irreligious, he judges with severity E. P'sichari's Veillé du Centurion as lacking in genuineness, and he speaks with little reverence of L'Appel des Armes: "That one," he says, "grates terribly on my nerves." 
And that duty is to defend the fields, the home, the loved ones, and also-for the soldier realizes it, though only vaguely perhaps- "to defend the universal conscience which Germany has outraged.' Julia's hatred of war is as deep, perhaps deeper, than that of earlier writers we have mentioned..$^{37}$

* * *

A book which belongs to the same general class as the preceding, but must be dealt with separately on account of a very great difference in tone, is Georges Bonnet's L'Ame d'un Soldat. The book was much praised by some when it came out early in 1917, but it has since fallen into comparative oblivion. It was written at a time when the war had lasted a few months, but not long enough for one to realize what an enormous strain it would put upon the endurance of France and her allies; at a time when to some people like Romain Rolland, an attitude

37 If space allowed, here would be the place to study also two books of war recollections and letters, which are interesting as coming from men of strongly religious bent: one destined to become a Catholic priest, the other a Protestant elergyman. The first is l'Abbé Cheroleau (Ambulancier), caporal au $90^{\circ}$ d'Infanterie, by Emile Bauman; the other is Roger Allier, sous-lieutenant al IIe Chasseurs Alpins, in Memoriam (1917); they are the young man's letters published by the family. Both died during the war. 


\section{PERIOD OF DOCUMENTATION}

of detaehment seemed a mark of greatness; indeed, L'Ame d'un Soldat seems in some of its parts, to be a kind of new edition of Au-dessus de la Mêlée.

The author discusses the mental pictures which people have formed of the soldier of the great war, and also those books describing the "soul of the soldier," which have helped to form those pietures. The attitude of a judge which Bonnet assumes and evidently enjoys, eauses the destruetive part of his work to ontweigh the construetive. His business is to destroy "legends." Does the "heroic soldier" dear to the imagination of civilians exist?-No! Does the conventional "Boche" exist? No! Is there, as some have said, a revival of the religious spirit among soldiers?-No! Some maintain that the soldiers now despise those republican institutions which were powerless to avert war; is it true?-No!... And yet, after this holocaust of cherished beliefs, Bonnet admits that the French soldier is not a coward, that the Boche is not always gentle, that the serionsness of the times has led the soldiers to give thought to the mystery of human destiny and to the problem of death; he admits also that the soldier hates autocratic rule, etc. . . All considered, 
Bonnet is simply a man who refuses to grow enthusiastic over paradoxes, but who, at the same time, does not wish to think like everybody else; so that his love for the distinguo prevents him from making any forceful or really helpful statement. He does not even deal fairly with the questions which he is discussing. For instance, he writes: "cruel, ' mnintelligent, incapable of initiative, always ready to run away from danger, such is the classical picture of the Boche." But is that the conception generally accepted? Surely no intelligent man ever believed it; there was therefore no need for a long refutation of what no one believed who really counts. $^{38}$ And what is to be thought of the following commonplace?-"Will the soldier, when he returns, be selfish in consequence of his soldier's life which favors self-centered thoughts?" - "There is no need to entertain fear on that score," says Bonnet, "for while the returning soldier will work with more eagerness for himself, he will be better able to contribute indirectly to the general welfare." If, therefore, Bonnet's book has not the dogmatic tone of some other war time publications (see Benda, Lote,

38 It would have been much more interesting if Bonnet had named some of the books at which he was aiming. 


\section{PERIOD OF DOCUMENTATION}

Sageret, Lysis, ete., in the following chapter), neither has it the vigor nor the originality of these. Bommet will be liked by people who have no taste for strongly expressed opinions. His book affeets one as would the report of a psychologist who, watching his own daughter die, had set aside his paternal sentiments in the interests of seienee. If Bommet is not a monster of indifferenee, he surely cannot escape the reproaeh of being an insufferable pedant.

\section{Philosophichl Type-Second Phase}

In 1917 the war entered upon a new phase. It was at first thought that it would last a few weeks, then a few months, then possibly a year, then two years, then three; until, finally, all attempts to guess how long the war might still last were given up for fear of inability to bear another disappointment. Nerves seemed to be the only thing that "kept one going"; and at the same time they were the very thing that rendered the situation unbearable.

America had now joined the Allies; but it was impossible yet to gauge the time or the extent of her coöperation upon the battlefield. Meanwhile, the submarines wrought havoc on the transportation of food and munitions; and the 
pacifists were wailing out their sinister gospel, helping the perpetrators of brutal crime, and doing their worst to dishearten those who were fighting for justice.

Literature, of course, could not but betray the dreadful state of mind of the French people. It was inconceivable that authors should retain a calm philosophical attitude. They did not. But neither did they wish to appear to be weakening.-Better, then, say nothing at all ?-But, of those who set their teeth and still chose to write, some made their readers mistake their grim expression of suffering for a smile, while a few others kept on describing the state of their souls; but they deseribed them as they were, i.e., as keyed up to a point which seems beyond the powers of human endurance; they showed that their capacity for pain had increased by long and incessant training, so that their system had become like a most sensitive instrument registering even infinitesimal waves of pain brought about by the cruelest of irresistible and senseless fates.

* * *

Adrien Bertrand was one of those who assumed the tone of the smiling philosopher, in the volume which followed his alert and vigorous Appel du Sol. It was in 1918 that appeared 100 
his Orage sur le Jardin de Candide, a book of recollections and comments in the form of philosophieal essays reminding one of Diderot's Romans or Renan's Dialognes, keen, raey and full of grace. The first essay is in the form of a symposium attended by Candide, l'Abbé Coignard, Vaissette (of the Appel du siol), Pickwiek, Don Quixote, Faust (the "boche") and Achilles. The title indicates elearly that Bertrand was attempting the Voltairian style. What did he mean? IIad the sincere and fearless writer really become a cynic? No, indeed,for intense suffering renders superior beings better, not worse; moreover, after all the apparently light comments, his closing word uttered by Candide as he looks at the devastated garden is Travaillons! But let us recall the circumstances. Bertrand had been wounded beyond all hope of recovery, ${ }^{39}$ and it was on his hospital cot, and in the full conscionsness that day by day his life was ebbing, that he wrote his Orage sur le Jardin de Candide: he knew that his countrymen had hailed him as one of the promising writers of younger France: and thus he was passing away with fame, sweet fame, ready to smile upon

$39 \mathrm{~A}$ wound in the chest had been followed by pulmonary tuberculosis from which he slowly died. 
him. To assume in such circumstances the style of a cynic was heroism! It was, on his part, a wager with death; a wager that the gloomy prospect would not erush his spirit. This volume reminds one of the cry of the famous stoic: "Pain, Pain, thou dost not constrain me to admit that thou art an evil.', 40

* * * $\quad *$

Some one might perhaps be inclined to offer as explanation of the supercilious tone of Bertrand (in 1918) that he had ceased to be an eye witness of the horrors of the battlefields. We do not think that that explanation could be regarded as psychologically sound, in view of the ever present image of impending death. At any rate such an argument would not hold in the case of the best example of that kind of writing, Jean Giraudoux's Lectures pour une Ombre (1918). ${ }^{41}$

Giraudoux had signed in 1912 a book which had the grace and elusiveness of morning mists; its humor consistently light, was sometimes keen,

40 After his death a book of verse by Adrien Bertrand was published, Tierge de Cypris, of which it is not possible to say with certainty whether it was written before or after the commencement of the war.

41 The book is dedicated to "André. Dufresnois, disparu," who is probably the "shade" for whom the "readings" were prepared. 


\section{PERIOD OF DOCUMENTATION}

but more often subtle; it was appropriately called L'Ecole des Indifférents. Since and throughout the war, Girandoux maintained that same attitude of detaehment. His Lectures pour une Ombre are neither boisterous nor grim, nor do they depend for their effeetiveness on any exaggeration. If at any time he shared the emotions of France and of the rest of the world, he does not betray them.

At the outbreak of hostilities, he joined his regiment and went through the tragic first six weeks of the war with a smile on his faee. The trials of the flesh seem to have been non-existent for him; in the midst of blood, fire, mud, and the roaring of guns, he remained perfectly serene.

Giraudoux made notes on the battlefield, but did not however write his story until later, after "years in the trenches" (p. 281). And this is indeed the miraele: that he could have lived through three years of horror after the first six weeks of the war, without changing anything in his attitude, and should even then be able to recount the story of the battle of the Marne without any trace of emotion, just as if he were describing an evening spent at the Palais Royal. Giraudoux tells us himself that he took down in telegraphic style the report from the General 103 
Staff to his unit on Sept. 6th, 1914 (we refer to Joffre's famous order of the day), but that he was: "not particularly moved by it, for we are used to receiving, like a telegraph clerk, all sorts of orders of the day"' (p. 170). We must admit that-extraordinary as it may sound-the whole book impresses one as genuine; there is nothing in it that would justify a suspicion of pose, or of desire "d'ćpater le bourgeois"; nor is the tone cynical. It would seem as if, really, in the midst of the most stirring events, Giraudoux found a sort of sly satisfaction in ealmly noting down the drolleries of the situation. "The German trenches are only a few yards in front of ours. It is raining death. Jalicot, just to tease the Germans, shouts to them: "Surrender! give your answer in French so that there may be no misunderstanding!' The Germans, who, aceording to their habit, took the challenge in all seriousness, answered by an earnest: Non! Non! then they shouted to us to surrender, and we answered in ehorus, using, all of us, one and the same word: $m$...! And they were very much annoyed beeause they had answered politely" (p. 236). Another time Girandoux finds himself in the midst of wounded men begging pathetieally for relief. He has nothing to say of 104 
their distressing appeals, but he notices a young theologian who, believing in the immortality of the soul, dares not use the words "I am dying," in endeavoring to attract the attention of the doctor, so prefers to say: "I exist no more! I am ceasing to exist!" (p. 239). When Giraudoux rises in the morning, his mind full of the previous day's fighting, and with the certainty' of more fighting to come (for this takes place during the battle of the Marne), he admires the sumrise and ealmly deseribes it: "A fine day. The fact once admitted that one has to get up, one ought to judge of the weather without prejudice. The sum leaps from clond to clond; the cloud that eontains it is bathed in gold. The sky is light blu, with deep blue patches. Autumn eontimues to pluck one by one the yellow leaves from the chm trees, while at each moment, great limbs are torn off by passing shells" (p. 241). And after the victory las been won, when the troops pass through the reconquered villages, and the people come out to greet them with every sign of intense joy, and with tears of gratitude, Girandonx again has eyes and cars mainly for odd ineidents: "A blinel is cantiously opened and the head of a sister of charity appears at the window.' When the good sister 
recognizes the uniforms of the French soldiers, she flings up her arms and exclaims: "Ils sont partis, les cochons! ils sont partis!" (p. 271). In another place, girls come out and pour bottles of perfume on the soldiers' hands, and, when allowed to do so, on their heads; while a woman hands to the soldiers, through a cellar window, pots of jam, cheese, and other victuals; some cven thought that the soldiers would appreciate "eau de botot" for cleansing the teeth (p. 278).

That is the tone of that astonishing version of the battle of the Marne, which would surely have surprised even the author of The Ring and the Book.

Let us repeat that this kind of style is evidently a paradox; but it is surely an heroic paradox. For it requires a remarkable amount of self-control, of indomitable individuality, to go through the experiences of Giraudoux without becoming infuriated or mad or melancholy or sick with disgust or even heroic in the usual sense of the term; so that, while the book produces on the reader a sensation which is absolutely sui generis, and while it affords curious reading, it must be confessed that it is in no wise moving. ${ }^{42}$

42 Since the publication of Lectures pour une Ombre, 106 


\section{PERIOD OF DOCUMENTATION}

Among the expressions of a sensibility which has beeome almost morbid through an exeess of moral suffering, André Fribourg's Croire, Histoire d'un Soldat, should be singled out as of the very best. ${ }^{43}$

Croire, like Le Feu, is the story of a squad, but the reaction of the author of Croire is not that of an emotional artist in whom suffering arouses revolt; it is that of a sensitive soul of the Paseal type, who understands that man's eapacity for suffering is the sign of his greatness: "L'homme n'est qu'un roseau, le plus faible de la nature, mais c'est un roseau pensant. Il ne faut pas que tout l'univers s'arme your l'éeraser. Une vapeur, une goutte d'eau suffit pour le tuer. Mais quand l'univers l'éeraserait, l'homme serait

Giraudoux has written a little book entitled Amica America; it is illustrated and was published by Emile Paul, Paris. In 1918, he published a novel which was written before the war and which bears the title: simon le Pathétique. The reader will searcely need to be told that the word "pathétique" is to be taken cum grano salis.

43 Croire was awarded the I'rix Sobrier-Arnould in 1918, and the same year the Académie des Sciences, Morales et Politiques awarded the Prix Audiffred to Fribourg's Les Martyrs d'Alsace et de Lorraine, d'après les débats des conseils de guerre allemands (1916). In 1918 he published another historical work, Le P'oing Allemand en Lorraine et en Alsace (18\%1, 1914, 1918), 10,000 copies of which work were sold in a very short time. His previous works dealt mainly with the history of the French Revolution. 


\section{FRENCH LITERATURE OF THE GREAT WAR}

encore plus noble que ce qui le tue, parce qu'il sait qu'il meurt, et l'avantage que l'univers a sur lui, l'univers n'en sait rien. Toute notre dignité consiste donc dans la pensée. . . .',

Fribourg repeats words of protest and of revolt; but he searches decply what caused them, and he always has a sympathetic attitude, for to know all is to forgive all. Moreover, those outbursts of despair are only temporary; the good side, the lofty, heroic side of human nature always asserts itself; often it manifests itself in the form of la gaieté française which assumes under Fribourg's pen a deep significance. The book offers painful reading at times. Fribourg's masterly pen carries the reader along and makes lim live in imagination through those hours of absolute exhaustion resulting from fatigue, cold food, and the everlasting dampness of the trenches. One must read those pages describing the depressing effect produced by hour after hour, day after day of incessant rain (pp. 86-90) ; and also the description of the mournful hours of waiting in the trenches, where the soldier, perfectly helpless under fire, yet perfectly conscious of his situation, lives in hourly expectation of death.... "After fourteen hours, death is still here. It plays with us, 


\section{PERIOD OF DOCLMENTATION}

brushes against us, withdraws, eomes back, leaps to the right, hurls itself to the left, growls to the rear, then rises, flaming, in front of us. . . Minute after minute bombs and shells explode. . . How sad is that death which threatens us. The conscionsness of our individual impotence is erushing. . . How could we strive against the omnipotent machine, against that tearing force which, within the next second, perhaps, will blindly seatter the fragments of our bodies? This is not the war of which we dreamed in August, a eheerful singing war in the broad sunshine! We had hoped for epic contests, and we are going to die, ground to dust by iron shards, thrown by an invisible hand, at the bottom of a diteh, in the mud" (pp. 135-6). One must read also the terrible episode of the soldier whose mind suddenly gives way under the stress of waiting and whose mad cries may betray to the enemy the presence of the squad so that his friends are obliged to seize him and gag him lest he should bring upon them all a certain and immediate death (pp. 128-130); or again the deseription of the attack in which 300 men set out and only four returned.

The originality of Croire, however, lies in the theory whieh it expounds. The title and sub- 


\section{FRENCH LITERATURE OF THE GREAT WAR}

title expresses it well. Croire, histoire d'un soldat. Without knowing it, the French soldier had set out in obedience to a noble impulse. Of this he became clearly conscious only very gradually, through the medium of the sufferings which he was made to endure. But from the beginning he was loyal, even from before the beginning. As early as 1911, the German menace had prepared the mind and heart of the soldier for the events of 1914. This is remarkably well brought out in the Prelude to the War Diary, Aux Manouvres d'Argonne, Pendant le Coup d'Agadir. Fribourg assures us that he has therein reproduced his notes as he took them down on the spot. Pacifism was in those years rampant in the army; the men made no secret of their feelings in the matter and openly expressed their detestation of war. Fribourg is careful to emphasize this fact. Each time that anything annoyed them, they would noisily protest: "Ah! they'll never catch me here again, never! never! When I get out of it, I'll make a bee line for London, and make a declaration that I intend to take up my residence permanently there! . . . I'm sick of it!'” (p. 17). Or . . . "Moroce be damned!'-_'I'll not go and get my face smashed by the Germans" - "Let the capitalist 
bosses do the job if they want it done!' (p. 24). Or again when a cyclist is jokingly told by one of his fellows that his helmet gives him the appearance of a Prussian, "Prussian or Frenchman," he answers without the slightest hesitation, "one is as good as the other!" (p. 28).

And yet, at bottom, they did eare; they felt the thrill of marching through the villages at the sound of the band. A great wave of love of France and of liberty came over them as they rehearsed a charge; and when they saw the admirable manœuvering of the artillery and of the aireraft, they felt a pride at belonging to the army of France. . . . And when the evening papers brought unpleasant news concerning the Moroeeo situation, the spirit of the poilus of 1914 was already manifest in the tone in whieh they said: "Those fellows are getting on our nerves at last!"

That sporadie feeling had grown and was ready for its full expression when the eall to arms eame in Angust, 1914. Once more, in Fribourg, we have a confirmation of the oft repeated statement that France was fully conscious of what was happening, in the deseription of the fateful minutes of farewell, of tragie silent, heroic farewell. "Moments which resemble 
no others. . . . I know that I am living through an experience infinitely great and infinitely rare; a flash which will illumine and sanctify a life to its last moment; I know that one never can feel again such emotions as those which are filling my heart; and yet, all at once, in the midst of my joy, an unlooked-for anguish lay hold of me; it is short, indefinite; for I have thought that the enthusiastic songs which sweep over the harvest fields are proclaiming that lovely peace is dead, that her form is even now being wrapped in a shroud"' (p. 43).

Now we come to the war itself. After the first long taste of it, after weeks had been spent in that deadly Bois des Chevaliers, when the men lave learned what war really means, the exaltation of the first moments yields to resignation, but a resignation which one accepts only because it ennobles; it is the gift which comes to those who know the worth of sacrifice.

"War, thou art an act of faith and of renunciation... War, we have given up everything to thee: wife, and family, and our heart, and more than that, our minds of which we were so proud. War, we have endured, in obedience to thy law, humiliations, mortifications, suffering; 


\section{PERIOD OF DOCUMENTATION}

our life is naught but watching and fasting and silence; we have become, for duty's sake, poor, equal and chaste; we are struggling against the cold, against the mud, against the gloomy power of shells; we are scourged with bullets; the thought of death is ever with us; like Trappists we bury our dead brethren, and in digging our trenches we are preparing our own graves. War, who teaehest withont willing it the good and the horror of force, thou art full of sadness and of greatness, of supreme joys and of bitter despair; thou art a fiery trial which kills or purifies; thou bringest new men out of thy erueible and thou savest them while they, through their sacrifiee, redeem their brethren who fight not, as also the disasters which overtook their fathers, the impotence of the weak and the faults of the dead"' (p. 149-150).

And the book closes with a confession of faith; a confession which comes as a refrain in each chapter, and which beeomes more and more definite each time, yet remains so hroad that all faiths are included in it: "Let us learn how to love, to suffer and to die, that is, let us learn to believe. Let us in the broadest sense of the term believe, like the marty's of all eauses; like 


\section{FRENCH LITERATURE OF THE GREAT WAR}

those believed who were first to fall in August, 1914, who went to their death with songs upon their lips"' (p. 252).

The word "believe" as used by Fribourg is very plain and simple, but it grips one in a strange manner as one proceeds with the reading. At first the reader gathers no clear coneeption of what is implied in the smooth running text, but it all beeomes clear to him when he turns to the last ehapter.

The man who wrote Croire had left for the war full of health and strength; he was diseharged in September; 1915, and returned with sight, smell and taste considerably impaired. He had to set about reëducating himself with touch and hearing as almost the only senses. The reference to his return to his elass work in Paris, his meeting with the youths whom he had taught before the war forms one of the most pathetic passages of the book. No attempt was made either by teacher or pupils to express in words the emotion of the reunion; but the substance of many eloquent and moving speeches was conveyed by the attitude, the very silence of the pupis. It was evident that all knew what had happened, but that all felt that it was a matter too delicate, too saered for words, and that silence was the 
best and only adequate medium to express all the complex emotions of the moment. One cannot help thinking, in reading that premiere classe of Fribourg, of the well known and touching dernière classe of Daudet. ${ }^{44}$

* * * *

The second,-and the best type of book of this kind,-though affording even more painful reading than Croire, is Henry Malherbe's La. Flamme au Poing (1917). ${ }^{45}$

Malherbe analyzes the state of mind of the soldier who has reaeled the limits of human endurance, and who yet, by some super-physical force, still manages to "keep going." The anthor's naturally sensitive soul has become distressingly so after three years of strain. In this work the reader will find no more references to the pangs of hunger, the painfulness of wounds or the

44 Fribourg is professor of History and Geography at the College Chaptal, Paris.

45 This work was awarded the Prix Goncourt for 1917. It is worthy of note that the men who award that much coveted prize have shown really wonderful skill in selecting each time, if not necessarily the intrinsically best book of the year, yet the best representative of the special nuance of literary evolution. Their choice for 1915 was Benjamin's Gaspard; for 1916, it was both Bertrand's Appel $d u$ sol and Barbusse's Le Fell (there were two in 1916 because one was left over from 1914); for 1917, La Flamme au Poing; and we shall see that their choice for 1918 was no less happy. 


\section{FRENCH LITERATURE OF THE GREAT WAR}

feeling of physical exhaustion which earlier writers so frequently insisted upon who wanted to make their non-combatant readers realize that heroism consists less in spiritual exaltation than in the endurance of material privation and in the exertion of physical strength. It is not that Malherbe ignores or denies the reality of these things, but rather that he has ceased to suffer as a physical being, because the tortures of his mind are so much greater. There is something truly Dantesque in those pictures of tortures of the flesh, which have become to him merely symbols of moral pain. He lives in the compauy of abstract beings: Memories, Love, Death, which haunt him, which are themselves but pale reflections of some metaphysical reality : "Our actions during these months of agony are not prompted by our poor little human selves, but by some higher power' ; and the soldier of the Great War is resigned not to understand: "we are working at some mysterious task which must surely be very great; when shall we be worthy or clear-sighted enough to eatch a glimpse of the hidden motive of all the violence that is done us?'” (p. 85).

He is haunted by gruesome memories of the battlefield which are more than he can bear. 


\section{PERIOD OF DOCUMENTATION}

What should he do? "Can it be, oh my lost friends, my tormented brothers, that some day I shall forget your features, and the untold sacrifiees which ye made, poor leroes!. . . No! I feel that I must keep in mind those pictures and portraits, so fresh, so perfeet in their brilliant and bitter realism that they eannot be dimmed by any nightmare or any vision of feverish brain. But I camot, I dare not, describe with aceuraey all that distress; it passes the strength of my heart, my poor heart torn with pity, and overwhelmed with grief. And, I eonfess it, I am afraid that too real an evocation of those scenes would make me live over again those days of feroeity and death" (p. 58).... "Oh! that I might eseape from these infernal regions!" (p. $96)$. . . "Who are those sly, eriminal, shamelessly eruel enemies? Are we fighting against armies or maniaes?" (p. 99). So used have the soldiers become to living in this atmosphere of death, that they also are as dead men.

Malherbe's pictures-as has been said-are not real in the sense of faithfully reproducing what he has witnessed; rather are they images meant to evoke in the mind the tortures of his soul. The reader may like to read some samples of that style. Sometimes he attributes even to 
inanimate objects a capacity for moral suffering, as, for instance, in his descriptions of the devastated villages: "Here are some wreeked homes, sadly surprised to see their wounds reflected in the running stream; there, some old homesteads to the battered roofs of whieh some red tiles still eling: infinitely pathetic old dames, they seem, shaking with the palsy and groaning with pain, their heads wrapped in their red plaid kerchiefs. And farther on, silhouetted against the angry sky, are the pitiable and battered forms of limping and rusty plows and broken earts and wagons. And all these things move one as if they were living beings kneeling down before one, bewailing their sorrows and begging for pity or for revenge" (p. 62).

And here are a few other characteristic sketches:

"A 304 fell among us. It erashed through one house without exploding, passed through the wall of another and burst. Of the sixty men who were there, thirty were killed or wounded. One man was cut in two through the stomach. He crawled away on his hands in a river of blood, leaving behind him the other half of his body, and howling as he went....' (p. 83-4). 
"They told the eaptain not to venture out, for the fort was being heavily shelled: 'Wait!' they said. But he ánswered; "No matter, we must relieve our eomrades who must be exhausted hy this time. Forward!' And they went. A 210 shell fell right among the eompany; thirty men were killed outright. The eaptain's head was found four days later" (p.93).

"A miserable grave marked by a eross made of two stieks; and on it the inseription: Zouare? Chasseur??" A first time the eorpse was buried; a shell unearthed it. They buried it again. A seeond shell brought it out once more. There was a third burial at the hands of sad, pious, devoted eomrades. But a third shell has again thrown into the air those ghastly remains. And now they eall him the Clown. When shells fall round, and they see mud and bones thrown up, they say: 'Why, there's Gugusse on the jump once more!'-What maledietion is pursuing that unknown soldier?" (pp. 168-9).

And then in ehapter XVIII (The Descent into $H e l l)$, he tells of an offieer who has lived through sueh a sueeession of hideous seenes, that he actually believes that he has sojourned in hell and has learned many things unknown to ordinary 
mortals: "I know that I shall not return after the war. What is even more tragic is that I recognize those who are marked for death as $I$ am, all of whom will be to-morrow my comrades beneath the ground"' (pp. 206-7).

In September, 1918, Malherbe published, in La Grande Revue, Le Jugement Dernier. It is a remarkable piece of poetry in prose: the rêverie of a soldier from the moment that he realizes that he must die of his wounds, to the moment of his passing away. It is-if we may so speak-a piece of soul-vivisection. He takes the suggestion made him by the surgeon, that he should go home to die. There, as one already dead, he communicates with those whom he has left behind . . . mother . . . wife . . child . . . brother and friend. He also sees passing before him his past life. He sees himself at the age of fifteen when his mind timidly began to work; then at twenty when his thoughts are filled with love dreams (Fernande, Margot, Sophie, Madeleine) : and again at thirty on the eve of the war. Finally, he describes his absorption into Nature, he feels himself melting and vanishing into the great mysterious All. . . . He finds it difficult to realize his connection with the infernal 


\section{PERIOD OF DOCLNENTATION}

realities of the Marne and of Verdun; and yet it was his experiences of the battlefield that had delivered his soul from the thraldom of things material. ${ }^{46}$

Malherbe's book reveals the intensity of moral agony which the war has brought to a man of refinement and culture like himself (as Fribourg had done, though less despairingly, in Croire). But Dr. Georges Duhamel has made himself the interpreter of the so-ealled lower classes; he has shown in them an equal capacity for intense moral suffering which reveals refinement of feeling not generally attributed to people in that station of life. His Vie des Martyrs has therefore been greeted as one of the finest war books, one of the most "poignant."

Physicians, indeed, occupy a prominent place among the writers who have made valuable and reliable contributions to the literature of the war. In a general way, one ean say that physieians form one of the most cultivated classes in

46 The reader may be interested in still another book of sorrows: Andrế Delemer, l'élerin 1/utilé, blessé de Vauquois (1918). In this book, the author expresses,with outbursts of bitterness at times. -his despair at seeing his life broken by his mutilation. The story is told of a lady who fainted when some passages of this book were read to her. 


\section{FRENCH LITERATURE OF THE GREAT WAR}

France, which fact, combined with the exceptional opportunities that they have of observing human nature when stripped of the veils of conventionality and the masks of civilization, renders their testimony unusually authoritative. They are more accustomed than others to witnessing dramas which are not comedies, and displays of cowardice-or maybe of courage-in the presence of death, or at the operating table; this renders them more moderate than others in their appreciation of war scenes. They are not so likely to overestimate the influence of present events on the liuman machine, because they, of all people, are in a position to judge when and where the war has added something to human reactions.

Quite naturally, these men have felt that they had something to say which was worth saying, even if it had nothing to do witl military operations or with episodes of an epic character.

A number of physicians, therefore, have written books which have been widely read. Among them are Le Courage (Alcan, 1917) and Le Cafard (Grasset, 1918) by Drs. L. Huot and P. Voivenel. But those two works are of a scientific, rather than of a literary character. Then, there is Léopold Chauveau's Derrière la 


\section{PERIOD OF DOCUMENTATION}

Bataille (1917) a valuable colleetion of episodes from ambulanee and hospital: snapshots, as it were, of Keratro, the Breton, with a fractured skull; of Renard, whose IIerculean chest has been torn by shrapnel; of Leroy who is ever cheerful and hearty in spite of his erushed leg; of Cazalis who eomes from Nice and howls even before he is touched; and of Massou, the cannibal from Algeria, a big, trust ful, but unbearable child. Facts are allowed to speak for themselves; sometimes they are, of eourse, very depressing, but sometimes, too, they are eomforting; for nothing has yet been found that is so true a eriterion of human nature as the way in which sorrow and pain are endured. There is also La Marsouille ${ }^{4 i}$ by Paul Fielle, to which Dr. G. Dumas eontributes a preface (1917); and $U n$ Médecin de France, Lettres d'un Médecin Auxiliaire, 31 juillet 1914-14 avril 191\%, with a preface by E. Boutroux (1919).

But Duhamel has won undisputed preëminence among physicians who are also writers. Long before the war, he was well known in the realm of letters. He was one of that group of writers and artists who, ten years ago, had ar-

47 "Marsouille" is the nickname given to the ambulancers who pick up the wounded on the battlefield. 


\section{FRENCH LITERATURE OF THE GREAT WAR}

ranged to live together in the communistic colony "I'Abbaye,"-a kind of French "Brook Farm," - so as to stimulate each other in their artistic efforts. Among his associates were men like Jules Romain, author of La Vie Unanime; Ch. Vildrac, author of Livre d'Amour; René Arcos; and others. Duhamel had occasionally written for the stage; his La Lumière was produced at the Odéon, and his Le Combat, at the Théâtre des Arts. He had also written two small volumes of poetry: Des Légendes, des Batailles, and Compagnons; and two volumes of critical essays: Propos Critiques and Les Poètes et la Poésie. He was especially interested in the new technique of versification, and was regarded as an authority on Vers libres. It was for this reason that he was appointed reviewer of poetry for the Mercure de France in succession to Pierre Quillard.

The war was to reveal to Duhamel a new world and to turn the poet and the physician within him into a philosopher. He was by no means naturally addicted to emotionalism : a fact which lends authority to his estimate of the French soldier. The "sweet reasonableness" of his book makes it a most effective antidote to the sinister pessimism of Barbusse's Le Feu, as well 


\section{PERIOD OF DOCUMENTATION}

as to that shallow optimism of the anthors aimed at by Barbusse, who dipped their pens in sublimity, and saw in every Freneh soldier a smiling hero, eheerfully accepting any sacrifiee for his eountry. To the optimist, Major Duhamel opposes that poor human machine, naturally yielding when the power of resistance flows out with the life blood, and for which he has nothing but sympathy; while to the dogmatic pessimist of the Barbusse type he opposes the quiet and beautiful resignation of many a plain "poilu" who has reeeived from nature a great reserve of moral strength,-and the number of these greatly exceeds the number of the disconraged. Throughout the book, one feels that his observation is sound, is fair to the individual beeause it is based on an intelligent appreeiation of each case. But the effect upon the reader is not less distressing than that produeed by Malherbe's book; it awakens an immense compassion for those whom Duhamel has so appropriately ealled "Martyrs," and who very frequently are "Saints" also.

Major Duhamel was long stationed in a ehâteau transformed into an hospital, not far from the front, in Artois, near Rheims. That means that he was in uneeasing personal touch with the 
grands blessés, i. e., those men who were too seriously hurt to allow of transportation further into the interior, and who required immediate surgical attention. At a later day he was summoned with his unit to Verdun; it was at the time when the great battle was in progress, and there again he saw many of the most desperate cases.

One could not, without spoiling them, reproduce in abbreviated form the tales of sorrow,sometimes of hope,-which Major Duhamel has so graphically told: the long suffering of "Carré and Lerondcau"; the "Sacrifice" of the two legs of Léglise: the story of the German officer in "La Troisième Symphonie"; the little gem called "La Grâce", which tells how poor Grégoire who, having received the gift of "grace," did not "know how to suffer," and therefore "suffered much more than the others," while Anger "knew how to suffer" and was perfectly happy, and was ashamed because the fine ladies who visited the hospital gave him all the candy and cigarettes; and how he found a touching way of passing some of it to Grégoire without hurting the feelings of the "pouter."

Some examples of Duhamel's style ought, however, to be given. The following bits of transla- 


\section{PERIOD OF DOCUMENTATION}

tion are by Professor H. Isabelle Williams of Smith College: ${ }^{48}$

Were modesty banished from the rest of the earth it would doubtless be found hidden in Mouchon's heart.

I ean still see him being brought in on his stretcher, eovered with gravel, his soldier's cape heavy with mud, and his fine frank face of a well-bred elild.

"Have to excuse me," he says to me, "you ean't keep very elean. ..."

"Have you got vermin?" asked the orderly undressing him.

Mouchon blushes and is embarrassed:

"Oh, if I have any they wouldn't belong to me, that's sure-"

He has no lice, but his leg is broken "on account of a bomb."

They cut open his breeches, and I prepared to have his foot covering removed. Mouchon put out a hand and suggests timidly:

"You might leave my shoes on."

"Why, old ehap, we ean't dress your leg without taking off your shoes."

Then Mouchon, red with emotion:

"But if they take off my shoes ... it will smell. ..."

I have often thought of that answer. Believe me, Mouchon, I have not yet met the prince who is worthy to remove your shoes and wash your humble feet.

48 They were first published in Medicine and Surgery, December, 1917. 
From his belly there comes forth a bundle of bloody dressings and the odor of rotten intestines. With great precaution the doctor seizes the dressings with his forceps and draws them carefully out. A sunbeam illuminates the whole thing; the frail shack trembles with the cannon's roar.

"I am a well known dealer in china," mumbles the patient. "You are from Paris, well, so am I. Save me and you'll have something; I will give you a fine piece of china."

Little by little the dressings are drawn out, the forceps shine and the sunbeam seems to tremble, so heavy is the cannonade, as tremble also floor, walls, slight roof, the earth round about, and the very universe dull with fatigue.

Suddenly coming out of space, a yawling moan begins, increases, cleaves the air above the frail shack and the shell explodes a few feet away with the sound of a cracked object breaking.

The thin walls seem to sway beneath the rush of air. The doctor moves his head slightly merely to see, as it were, where the thing may have fallen.

Then the china dealer, noticing the motion, says in a peaceful voice:

"Don't you pay any attention to those what-youmay-call-'ems . . . they ain't dangerous. You just save me and I'll give you a fine piece of china, or of earthenware, just as you please."

The cause of the trouble is not so much the crushed leg as that slight wound in the arm which has let so much good blood escape. His lips are livid, hardly 


\section{PERIOD OF DOCUMENTATION}

distinguishable from the rest of his face, the pupils of his eyes are dark, immense, and from his face there shines forth a soul undaunted that will not yield till the last moment. He takes in, almost disapprovingly, the ruin of his own body, and watehing the surgeons busily serubbing their hands, he speaks in a meditative voice:

"Yon will tell $\mathrm{my}$ wife that my last thought was for her and my ehildren."

Oh, it was no roundabout question, for without hesitation the man yielded his face to the ether mask.

The eeho of his solemn words still resounded in the room.

"You will tell my wife. . . ."

There is no attempt to dupe this manly sonl with weak consolation-mere words. The white blouse turns around, the surgeon shows moist eyes behind his glasses and with deep feeling answers:

"We will not fail to, my friend."

The patient's eyelids tremble-like the motion of a handkerehief on a steamer that is putting out to sea, -then, breathing-in the ether, he sinks into a shadowy sleep.

It was his last, and we did not fail to keep our promise.

Mehay nearly died, but is not dead. Therefore all is well.

The bullet perforated the helmet, but barely touehed the bone. The brain is all right. So mueh the better!

Taking just time to wake up, reach a few times in 
memory of the chloroform, and Mehay looked with eager eyes at everything that was going on around him.

Three days after the operation, Mehay got up. And as far as that was concerned, it was simply useless to forbid it; he rould have disobeyed for the first time in his life. Taking his clothes away from him was not to be thought of, the brave keep their boots on!

So, Mehay got up, and his illness was quite done with.

Every morning Mehay got out of bed before daylight and seized a broom. With neatness and dispatch, he made the room as clean as his conscience. He forgot no corners; he knew how to reach softly under the beds without waking his sleeping comrades and without worrying the sufferers. Between times he passes the wash basin or the "pistolet," and he is as gentle as a woman in helping to dress Vossaert, whose limbs are stiff and painful. At eight o'clock the room is very clean, and as they are about to begin the dressings, Mehay suddenly appears in a white apron. He watches my hands attentively as they come and go, and he is always at the right place to offer the sponge to the extended forceps, to pour alcohol or draw up a bandage, for be learned at once how to bandage very cleverly. He does not say a word, he watches. The bit of his forehead visible above the bandage is furrowed with concentration and it bears the blue marks by which one recognizes the miner. Sometimes it is his turn to have a dressing. But the moment his turn is over, he stands 


\section{PERIOD OF DOCLMENTATION}

there, his apron over his stomael and silently hastens his activities.

At eleven o'elock Mehay disappears. Has he gone on an errand? Here he is again witl a big tray loaded with bowls, he makes the round.

At evening he brings the thermometer, and helps the orderlies so well that he leaves them little to do.

All the while, beneath their dressings the bones of his skull are knitting, and the red flesh starting to grow. But that calls for no attention. "That can take eare of itselt." A man can't remain ille, he works and trusts to his blood "which is healthy."

In the evening, when the night lamp sheds its light through the room and I enter on tip-toe to give a last look, I hear a roice spelling laboriously S-p-oo-l, spool. Mehay is learning to read before going to bed.

The lamp is left lighted, for the men are not vet asleep, and are snoking a bit. You have, of eourse, to see your smoke, otherwise what's the good of smoking.

I go over toward Cronin Octave. I sit down near the bed and say nothing.

Sucessive eannonades burst forth in noeturnal space and the entire room resounds like a well tuned drum.

Cronin turns toward me, his face lost in its bandages, and puts out a leg bathed in sweat from under his covers, for his ferer is high at this hour. Nor does he say anything; he knows as well as I do that things aren't well with him, but he hopes all the same that I shall leave without speaking. 
No. It has got to be. I lean towards him and say softly the necessary thing. He listens and his chin begins to tremble. That boyish chin of his with its blond down.

Then with his country accent he says in a tearful and shaky voice: "I have lost one eye, an' if I've got to lose my hand. . . " The one remaining eye fills with tears, and as his sound hand is exposed I press it gently before going away.

When my fingers approach his blind eye Cronin starts back slightly.

"Don't be afraid," I say to him.

And he adds with calm pride:

"When you have lived on hill 108, you can never be afraid of anything any more."

"Then why do you draw back?"

"It's my head that draws back. I don't know I do it."

And it is true; the man is not afraid but the flesh remains timid.

When the head bandage is nicely placed, what remains risible of Cronin's face is very agreeable, young, charming. I notice this with satisfaction and say to him:

"The disfigurement isn't bad on this side. They'll fix it up so well that you can still make a hit with the girls."

He smiles, touches his head bandage, looks at his mutilated arm, seems lost among old memories, and murmurs : 


\section{PERIOD OF DOCUMENTATION}

"All the same, the gals won't like me the way they used to."

Mereier is dead, and I have seen his corpse weep. ...

I did not believe such a thing possible. They had just washed his face and combed his gray hair.

I said to him:

"You are not forty, my poor Mercier, and your hair is already almost white."

"It is because my life has been so hard and I have had so much grief. I have worked so much, worked so much! I have had so little luek. . .."

There are fine lines of pain all over his face, a thousand disappointments have left their indelible traces. Nevertheless his eyes smile continually out from his withered features, his eyes are glorious with a sort of rare innocence and such a look of pure hopefulness !

"You will save me and perhaps I shall be happier in the future."

I say: "Yes." And I think, "Alas, no!"

But suddenly he calls me. The great dark eircle is darkening around the smiling eyes. His forehead drips with sweat. "Come, come," he says, "something terrible is happening to me. It must be that I am going to die."

We hurry to the poor paralyzed body, the face alone tries to express its agony. The hands scarcely move under the eovers. Grape shot has eut off the sources of life.

We do what we ean, but I feel his heart failing, 


\section{FRENCH LITERATURE OF THE GREAT WAR}

his mouth doing its best to claim one drop, only one drop from the immense cup of air. Little by little he escapes out of hell. I feel his hand making an effort to keep hold of mine.

"Stay near me," he says, "I am afraid. ..."

I remain near him. The sweat ceases to flow on his forehead. The frightful distress lessens. Air again flows into his wretehed breast. His gentle eyes smile on.

"You will save me after all," he says, "I have had too unhappy a life to die yet, don't you think so, doctor?"

I press his hand to give him confidence and I feel that his hard hand is happy in mine. I have plunged my fingers into his flesh, his blood has flowed over my fingers, that is enough to form strong bonds between two men.

Calm seems to have returned. I talk to him of his beautiful country. He was a baker in a Cantal village. I was down that way once, traveling in time of peace. We recali together the odor of the junipers, on summer days, on the green slopes, and the mineral springs of wonderful taste that gush from the mountain.

"Oh!" he says. "I shall always be seeing you." "Seeing me, Mercier?"

$\mathrm{He}$ is a very simple man, he tries to explain, but merely adds :

"In my eyes-I shall always have you in my eyes. ..."

But what is he seeing again now? What else is suddenly reflected in his eyes? 


\section{PERIOD OF DOCUMENTATION}

"I think-Oh! There, it's beginning again."

True enongh: the spasm begins again. It is terrible. Whatever we do, it gets the better of the rietim, and this time we ean do nothing. . . .

"I feel that I am going to die," he says. The smiling eyes still plead.

"But you will save me, you will save me."

I ean already see Mercier disfigured by death.

He says:

"Stay near me."

His nostrils are fluttering. It is hard to have been unhappy for forty years and to wive up forever the humble joy of smelling the pungent odor of the junipers.

And now his lips contraet and the eorners droop little by little so sadly. Oh! How sad to die after forty years of weariness, without even having time to sponge off this forehead, always bent over the daily task.

The saerifice is overwhelming and one eannot ehoose its hour; one must consent when the voice that elaims it ealls.

Each man must put down his implement and rise, saying only:

"Here am I!"

Oh, how hard it is to leave this life made up of work and suffering.

Once more the eyes smile feebly. They smile till the very last seeond.

He speaks no more, he breathes no more. His heart has stumbled, rallied, and stumbled again: now it is motionless as a foundered race horse. 
Mercier is dead. The pupils of his eyes dilate solemnly above a watery depth. All is over. $\mathrm{He}$ eannot be saved. . . .

Then, from the eyes of the dead man swell up great tears that flow down his cheeks. I see his features contract as if to weep through all eternity.

For long minutes I still hold the dead man's hand between mine.

One day,-he does not say what had happened,-Major Duhamel is struck by a terrible wave of discouragement: disgust, apparently, with men who will allow petty political intrigues to mar the sacredness of a war which claims such unheard-of sacrifices. The thought of the victims is what saves him: you may doubt anything in the world; you cannot, however,-especially if you are an army surgeon,-doubt the reality of suffering.

"At a short distance is the battlefield. The roar of the guns has not subsided for days. Like a noisy and complex mechanism, the stupid war machine grinds on and gives out minute by minute, the products of its interior activity: bleeding men. We receive them; they are wrapped in sheets. They have been torn with the swiftness of lightning, but it will only be with the coopperation of months or even of years, 
that we shall succeed in repairing the damage done. . . How silent they all are to-night! How disturbing the spectacle! . . In the tragie solemnity of the hour I gaze at those inmocent vietims, and I feel ashamed to be alive and to be breathing freely !

"Poor brethren! What could we do for you that would not be inadernate, mworthy, mediocre. One ought at least to give up all other preoceupations to devote oneself entirely to the saered and exacting task.

"But 110! Around your beds where your: lonely drama is being enacted, a sinister comedy is going on in which men wear grimning masks. . . Neither the four corpses which we buried this morning, nor your daily sufferings are sufficient to disarm those appetites, stop that scheming, brand those ambitions, which even your martyrdom serves to foster. . . Tet, remember the holy anguish of the first hours of the war!

"Never mind! Never mind! As far as I am concerned, I will remain here, among the stretehers loaded with their great bundies of grief. This is the hour when one may doubt of everything: of man, of the world, of the fate reserved for the just eanse. But one cannot doubt the suffering of men. It is the only thing which is 
certain at this moment. I shall remain, therefore, overwhelmed by the sinister evidence. And each time that Béal, who lies there with his stomach open, stretches his hand toward me, with his little smile, so often shall I get up to go and press his hands in mine, for he is feverish, and he knows how cool my hands always are. ...",

It is interesting to know that Duhamel's Vie des Martyrs was considered, together with Malherbe's Flamme au Poing, for the Prix Goncourt in 1917. In 1918, Duhamel published another work, Civilisation, to which the prize was awarded. This work is a kind of sequel to his Vie des Martyrs. The author has followed the same plan; his inspiration is the same, but the memoir style has been often replaced by that of the short story. It may be due to that fact, or to some other cause, but this second work does not seem equal to the first, and one suspects that the Prix Goncourt was in reality awarded to Vie des Martyrs through Civilisation. The philosophical ideas in the second volume secm to point to a development in the thought of Duhamel; these ideas are gathered up in the last chapter from which we quote the following lines: "Civiliza- 


\section{PERIOD OF DOCUMENTATION}

tion, real civilization, I have often thought of. It appears to my mind as a clorus of 1 meful voices singing in perfect harmony a hymm; or as a marble statue on the summit of a parehed hill; or it is as a man saying: 'Love one amother!' or 'Render good for evil!' But for nearly two thousand years, men have been repeating those words over and over again, and the high-priests have been too much eoneerned with secular matters to eonceive any other thought of like greatness or beanty. . . . I have studied with eare that monstrous Moloch in its lofty position. And I tell you in very truth that eivilization is not in that thing, no more so than it is in the shiny instruments of the surgeon. Civilization is not in all that terrible trumpery; and, if it is not in the heart of man, well, then, it is nowhere.',

Since the publication of Civilisation, Duhamel's thought has molergone still further derelopment. He has eome to a clear realization of what was brooding within him, and has expressed those new thoughts in various artieles whieh have appeared for the most part in the Mercure de France and in l'opinion, and in book form under the title La P'ossession du Monde (1919). 
That new philosophy of life is a praise of suffering which recalls some other famous paradoxical eulogisms of former days: the Praise of Folly, the Praise of Stupidness, the Praise of Poverty, etc. What his long meditations at the bedside of his "great martyrs," "what his contemplation of their patience, of their resignation, of their heroism, have taught Duhamel is that "suffering is beautiful, precious, desirable"; that suffering is "wealth"; that its attraction is "mystical"; that it is a "priceless though horrible treasure" ; that, moreover, suffering is what gives to art its impulse, and what "liberates the latent energies of our deepest faculties" ; and that "while joy often is repellent, real suffering attracts and fascinates." 49

49 Our readers may be interested to know of some other books dealing with ambulance work, and which, though they cannot be compared, as literature, with the books of Chaureau and Duhamel, yet contain some very beautiful pages. We refer to works of religious inspiration,- the inspiration coming from the soldiers whose cases are related by the author,-by Abbé P. C. Klein, Aumônier: La Guerre vue d'une Ambulance (1915; one of the very first books of the war), Avec les Diables Bleus (1916), and Douleurs qui espèrent (1917). Abbé Klein became Chaplain of the American Ambulance at Neuilly; his books were translated into English and were particularly well received in America. One may also read with pleasure J. Roussel-Lépine: Une Ambulance de Gare, croquis des premiers jours de la guerre (1916). And Ch. Hennebois: Journal d'un Grand Blessé (1915): a book which tells of the author's experiences in German 


\section{PERIOD OF DOCUMENTATION}

\section{Descriptive 'Tye}

We have spoken of soldier types in war novels; then of works written by men of philosophical bent who comment upon their experienees, and are anxious to expound their views and sentiments regarding the war; we now eome to those men who, relying more upon the eloquence of plain facts, than upon anything else, diseard all indirect methods, and, most of the time, any attempt to cultivate artistic form: men whose personality is kept in the background or at least is never allowed to obtrude.

But these war diaries are legion, and the task of selecting the best of them would be by no means an easy one-for, indeed, there are many which are "best."

The most consistent applieation of the method just referred to,- that of a perfeetly objective style,-is to be found in Les Diables Bleus pendant la guerre de Délivrance 1911-1916, by Louis Thomas, Lientenant an 66e Bataillon des Chasseurs à pied (1916). ${ }^{50}$ The fame achieved Hospitals. Hennebois's book will be analyzed later. Information concerning life in the ambulances and hospitals may be gathered also in Eydoux-Démian's Notes d'une Infirmière (1914), and in Noëlle loger's les Carnets d'une Infirmière (1916). See further titles in Vic, $O p$. eit. p. $297 \mathrm{ff}$.

50 He has also published Avee les Chasseurs (1916). 


\section{FRENCH LITERATURE OF THE GREAT WAR}

by the Chasseurs à pied and the Chasseurs alpins,-whom the Germans honored by the nickname of Blue Devils,-is a matter of universal knowledge. They were truly admirable; and the most fitting and dignified way of relating their deeds, was that adopted by Lientenant Thomas: a plain, unadorned record of them.

Sometimes his sentences are little more than statistical records in figures:

"Tête de Violu. Oct.-Nov., 1914.

"Nov. 3rd, 1914. The Germans began to bombard us at 9 A. M., and did not cease until 5:30 P. M.

"At 9:30 a sharp attack, as short as it was ineffectual, was made on Fort Regnault.

"Nov. 4th. The bombardment continued without infantry attack until $9: 30$ P. M., when a battalion attempted to storm our position on the E. and N.-E. of Violu; after a series of fruitless efforts in which the Germans lost heavily, they withdrew at $10: 15$ (p. 60).

"August 4-5, 1915, all our lines are being sub. jected to an extraordinarily violent bombardment. 40,000 shells of all calibers have fallen upon our trenches, our communication trenches, and our dug-outs and have destroyed them almost completely'” (p. 188). 


\section{PERIOD OF DOCUMENTATION}

At other times his entries are clear, eoncise and dry as military dispatehes:

"Storming of Hill 285. July 13, 1915.

"The commanding officer eharges, stick in hand, between companies $A$ and $B$, at the head of his pioneers.

"Captain Berthier de Wagram, magnificent, rifle in hand, Capt. Boneherot, and Lieut. Roulet, charge at the head of their eompanies.

"Eleetrified by the bugles, earried away by" the example of all its offieers, the battalion covers rapidly a distance of 700 meters and brilliantly earries Hill 285. Terror-stricken at the sight of the dark blue mniforms rapidly adrancing toward them through the woods, unnerved by the sound of the bugles which the ravines reecho, the Germans make off in great haste. Those who cannot get away kill a few of our men and Second-Lieutenant Olive, but whoever has fired is immediately bayoneted. The machine gunners rum away leaving behind their munitions. We take a few prisoners. They belong to the 130th Infantry and to the 6th Jaeger"' (p. 172-3).

At other times Thomas's style recalls that of military citations:

"Our poor Chasseurs reelimb the slope at one 
rush, sackless, hatless, and many of them without rifles. Very much exposed in their open and half destroyed trenches, many of them fall, but not one falls back. Corporal Bonnard, who remains alone with two Chasseurs of his squad, raises three fingers to signal to his C. O. the number of men remaining, and to ask for reënforcements. A bullet lays him low in the trench. Then, Sergeant Armand, one of the best fellows of the 6th company, is also hit. He was a priest who, desiring to fight, had by the connivance of the Major, been permitted to come forward before his time. He died in a shell hole after blessing his wounded comrades. Soon after, Lieutenant Fabre, who had fought since the beginning of the war without ever being hurt, fell cut in two by a shell splinter; it was in going to his assistance that the heroic C. O., Lieut. Marson, was thrown over by a shell, his chest torn open by three shell splinters; his right cheek half ripped off. To the end, he continued to give orders, maintaining by his example, at their post of duty, all those over whom he had command" (p. 68-9).

Sometimes, though rarely, a trace of emotion can be found in his account; but even then, it is 


\section{PERIOD OF DOCLMENTATION}

the soldier, not the man, who is moved: "More than ten fights of that kind took place during the night of the 13 th to the 14 th. The Chasseurs held on without flinching to the ground which they had conquered. The night battle was lighted up by rockets. It was a magnificent sight. The trenches were plowed up by trench bombs and torpedoes. When buried by an explosion, the men dug themselves ont and continued to hold on to their positions (pp. 17677).

"The general in command saw his men rush forward under heavy fire with an impetus which, as he afterwards said, sent a thrill of pride through him"' (p. 186).

But, generally speaking, if any lyrism is found in the book, it is in quotations of citations for bravery: "The general in command of the 10th army mentions in the order of the day of the army the 31st battalion of the chasseurs à pied under the command of Major Lalène-Laprade:

"On the 3rd, 4th and 5th, the battalion covered itself with glory by counter-attacking several times in succession the enemy who had taken a part of our trench system on the Notre Dame de Lorette plateau, winning back, one after another, five lines of trenches, and making many 
prisoners. The unit was withdrawn after losing 5 officers, 58 non-commissioned officers and 643 men" (p. 119).

But, one may ask: Is this literature?-As much so as the geometric style of Spinoza, or the terse little proverbs of the Bible, or the proclamations of great captains like Cæsar and Napoleon ... and the generals of the Great War.

It is irresistible. For the first 20 or 30 pages, the reader does not realize how moved he really is, because there is no grandiloquence, no apparent emotion in the writer. But after reading page after page, chapter after chapter; after taking in all those dry figures, all those names, (every one of which one knows to be that of an invincible hero), after noting all those little facts not one of which could be spared without marring the whole, the reader finds himself fascinated, spellbound. He realizes that he is living in an Eschylean atmosphere. The expression is not too strong. Such men are no longer men; they are demi-gods; not because they are descended from deities, but because they have achieved godlikeness. Never again shall the reader be able to hear without a feeling of great reverence such names as Tête de Violu, Hart- 


\section{PERIOD OF DOCLMENTATION}

manswillerkopf, Carency, Metzeral, Lingekopf, Bois des Caures, Mort Ilonme (in the Vosges) or Hill 60 (at Ypres). Nothing can surpass in heroic grandeur such episodes as $A$ u sommet de Hartsmanswillerkopf janvier 1915 (pp. 93 sq.) or Les Chasseurs de Bagatelle, 28 juin au Ier juillet 1915 (p. $161 \mathrm{sq}$. ). ${ }^{51}$

* * *

In Lieutenant Jacques Péricard's Ceux de Verdun (1917), we have a war diary which offers a real contrast to Lieut. Thomas's. They are just as objective statements of facts, but while Thomas relates his in a perfeetly passionless way, Péricard clothes his in fine epic or lyric garb. $^{52}$

This book describes the darkest days of Verdun. The author was with the 95th "régiment d'active" which, together with General Reibell's brigade, was cited in army orders for conspicuous bravery (p. 220).

51 Among the many names quoted by Lieut. Thomas, is that of Capt. Dubarle, 3le bataillon de Chassenrs, who was mentioned in army orders for conspienous bravery and decorated (Oet. 1stl, 1914): a man of indomitahle energy. He was killed after nine months of active service and his Lettres de Guerre (1918) is one of the hest soldier's diaries.

52 Péricard has published two other books: Face d Face (1916), erowned by the Academy, and Debout les Morts! (1918). 
A few quotations from Lieut. Péricard will show how he differs from Lieut. Thomas in his manner of relating this experiences.

As they approach Verdun, they are overtaken and passed by an endless train of automobiles, carts and wagons of every description which are bringing up men, ammunition and food supplies: "And still the train rolls on. The impression which one receives from that continuous, even-paced procession, is that of formidable power. One would say that all the vital forces of France are rushing to the threatened line. ..." (p. 59).

Lieut. Thomas would certainly not have used those or similar terms. He would not have analyzed his impressions. He would have described the line of vehicles-possibly made a statement in figures-and would have left the rest to the imagination of his readers. Neither would he have made a Shakesperean description like the following. The battle has lasted several days, and Péricard, 'wishing to convey to his readers an idea of the immensity of the slaughter, writes:

"The crosses which cover the neighboring fields do but deceive the eye; for no man can compute the number of the dead who fell at 


\section{PERIOD OF DOCUMENTATION}

Eparges and who remained without sepulture. "Each stroke of the pick reveals a corpse; each falling shell lays bare a skeleton; you pick up a boot which seems to have been forgotten behind a treneh; it contains a dying foot; you rub against a pieee of eloth embedded in the wall of the parapet, and find that it is a eoat still worn by its owner.

"Some of the trenches had to be opened through solid masses of eorpses; we had to eut through them as through stone in a quarry. Whoso walked through the works of defense before the job was eompleted, trod in putrefaction, choking with the nauseous stench, and was tripped up by sly shin-bones"' (p. 239).

And so all through the book. Thomas's deseriptions are just as grim as Périeard's, sometimes more so, but he does not insist. Thomas sees all these things with the eye of a soldier: Péricard allows himself from time to time to be more humane, and to lay stress on the sufferings of the soldiers; nay, lest the horror of them be forgotten, he brings in a sort of refrain which, repeated appropriately after certain battle deseriptions, reminds the reader that his aecounts are of hell:

"And the shells fall on, and on, and on. It 
is an infernal thunder shower, each drop of which is a shell. The trenches collapse, the corpses pile up, the tumult of bursting shells bruises one. The ground moves like water boiling in a caldron; the very heavens are out of gear ... and to oppose that hurricane, that avalanche, there are but the chests of men : chests which at each moment become less and less numerous, but more and more erect and resolute. ..."

How can those men bear the strain? Péricard confesses that he cannot understand, but he adds: "Who can measure the power of the will? or who could ever say to heroism: Thou shalt go no further!'” (p. 134).

When the enemy has shown himself unchivalrous, Thomas places it on record with other facts; but Péricard gives vent to his indignation. When, for instance, Fort Douaumont had been taken by a stratagem (the famous Prussian guards having disguised themselves in Zouave uniforms), Péricard scornfully exclaims: "And so those superb Brandenburgers, the pride, the glory of Germany, scored a success at the price of such treachery! You may triumph, William, that sort of triumph is worthy of you and of those whom you command!' (p. 146). 


\section{PERIOD OF DOCLMENTATION}

And how his hatred is kindled against the foe whose treachery has eaused the death of so many brave and honest Frenel soldiers-and against the shameless invaders who have left tears and death in their wake! Sometimes when he sees a family of refugees, the thought of his own litthe girl eomes to his mind: "Here is the face of my little Solange; here are her large eyes open wide with astonishment at all the unexpected sights, a tear trembling on the lower eyelid and ready to fall; here are her eurly loeks with a straw eaught in them for she has slept in the eold on a bundle of litter. I ean imagine $m y$ own child thus driven from the home, weeping as she goes along the highway, or seated in a eart, a little exile; and suddenly fieree anger wells up in my heart"' (pp. 55-6).

He has seen too much ever to forget and he brings his book to a elose with a solemn and impressive warning: "O Poilu, $m$ brother, a few words before I elose. Do not forget your hatred! Be watehful lest your generous disposition make it easy for you to forget: it would be shameful! Think of those who have fallen at your side; think of the towns that the enemy burned, of the women that he insulted, of the little girls he disemboweled. . . Think of the 
Braudenburgers of Douaumont who, to enter the fort, disguised themselves as Zouaves!... Think of the German machine gunners of Dricourt who, to get nearer to us, put on ambulance service uniforms and carried their guns upon stretchers! Think of your comrades of Larfée who, though wounded and prisoners, were made screens of by the Germans and fell by your own bullets . . . our France of to-morrow will need, to protect her, a high hedge of hatred. . . . You will have vanquished the Apocalyptic Beast, you will have broken its teeth and for a while you will be secure against its bite, but beware of its venomous breath, of the stink of its rottenness, and let your daily prayer be: 'Our Father which art in Heaven, enlarge our hearts that they may contain more hatred!',"

Let those whom those words may shock as being unchristian take the trouble to read the experiences of the man who wrote them; if, after that, they still preach compassion for the Germans, then we shall pity them for their hardness of heart, ... or for their softness of brain. ${ }^{53}$

* * * *

53 Many volumes of recollections of the Battle of Verdun have been published since 1916. They can easily be picked out by their titles from the list of the best war diaries which we give below (Appendix). Among the histories of the Verdun Battle as told by non-combat- 


\section{PERIOD OF DOCUMENTATION}

A work the tone of whieh is something between the deliberate impassiveness of Thomas, and the (sometimes) deliberate emotionalism of Périeard, is the excellent volume of Capitaine Delvert, Histoire d'une Compagnie (Main de Massige, En Champagne, A Terdun), Journal de Marche (191S), to which E. Lavisse has contributed a Preface.

The author is an intelleetual-a Normalien of the class of 1901. He writes well, and while avoiding the lyric and the cpic notes, he has a style which is distinetly literary. He willingly speaks of what he has been reading, makes conments on the newspapers and reports; but first of all he gives a rapid account of the happenings of the day, as the excellently chosen sub-title of his work (Journal de Marche) suggests.

The records begin on November 11th, 1915, date on which he is promoted to the rank of company leader, and continue until .June $26 \mathrm{th}$, 1916, when the company went out of existenee, the only remaining 37 men out of 151 having been sent to fill gaps in the ranks of other mits.

ants, we mention: Tollivet. L'Lipopée de Terdun, to which Lieutenant-Colonel Ronsset contributes a preface (1917), Henri Dugard, Bataille de Verdun and the very impressive aeeount given by an ere-witness thongh not a combatant. Henri Bordeaux, in his two volumes: Les Derniers Jours du Fort de Vaux and l'risonniers délivrés. 
Delvert himself was wounded four times, and, of course, was. decorated.

The Company is first sent to the Argonne where the roads are soaked, and the trenches are nothing but filthy cesspools. They are next sent to Champagne, the district of wrecked villages, with an outlook on neutral zones where barbed wire entanglements hold up corpses in putrefaction. Here the soldiers live in holes out of which they crawl only for fatigue duties, and they are so covered with mud that they look like large clods of earth. Their rifles also are clogged with mud, and the men are without drinking water. How they held out under such conditions, Delvert does not tell us; he only tells us that they did hold out, resisting terrific attacks which sometimes lasted for three consecutive days and were carried out with poison gas, liquid fire and deadly artillery fire.

(Unlike many others, he attaches little faith to the help that religion may bring to the men, as is shown by the parenthesis inserted on page 135 with reference to Bourget's Sens de la Mort. He considers that the natural cheerfulness of the French soldier accounts for the miracle: "une blague et ils sont remontés," - a joke and they are set up again.) 


\section{PERIOD OF DOCUMENTATION}

Later, the unit is sent to Verdun, and the ehange is for the worst. "The aspect of the trench is revolting. Everywhere the stones are dotted with little red drops. In some places there are pools of blood. On the parapet, in the eommunication trench, there are everywhere stiff corpses eovered over with tent eloth. A sore opens up in the thigh of one of them. The flesh is rotting away under the burning sum, it has swollen up, burst the eloth of the breeches, and large white flies are feeding on it. On the right, on the left, the soil is covered with nameless débris: empty tin eans, ripped knapsacks, piereed helmets, broken rifles covered with blood. An unbearable smell fills the air. And to make matters worse, the Boches are bombing us with tear-gas shells." (Verdun, May 14-17).

The volume is full of such descriptions. Delvert eares nothing for our nerves. The deseriptions are not all equal in length to this one, but many of them are equally horrible: they alternate, however, with occasional deseriptions of spring landseapes, of ravs of sunshine, which by their sharp eontrast enhanee the horror of the others.

Nowhere has a better description of the coekpit of Verdun been given than in the last ehapter 
of this book. It is interesting to note that Delvert, like Péricard, ends with a malediction of the Germans. It is just as sincere as Péricard's but is expressed in more classical literary form:

"Oh! the brutes! the brutes!

"And to think that the human race should be subject to the law of its inferior types: of those in whom the lowest instincts of the brute still dominate; and that the Spirit, bound to the cross these many hundred years, shall never, perhaps, be released. .

"Ariel and Caliban.

"These are the tricks of Caliban.

"He is pleased, indeed, and his heart swells with contentment! Where life universal had blossomed forth in vernal splendor, had called upon the trees to grow, the trees those peaceful children of full-bosomed Earth, who lift toward the light their supple limbs all richly draped with leaves; where life had ealled out the bushes, the flowers and the blades of grass, and all that wealth of beauty in which the kindly Mother of all beings and of all things loves to bedeck herself; where Ariel had taught the birds their sweetest songs and filled the glowing heart of man with harmonies; there, has Caliban flung- 


\section{PERIOD OF DOCUMENTATION}

with wonderful precision, we are ready to admit - his infernal machines of all sizes.

"And all that remains is a desert; a bloody and hideous desert! How happy he must be!"... (p. 288).

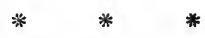

Captain Delvert describes mainly the life of his company in active warfare, ${ }^{54}$ laying stress on the great hours which the company lived through.' The aim of Max Buteau's Tenir, Récits de la Vie des Tranchées (1918) which is more recent, is just the reverse, namely, to describe the everyday life of the soldier of the Great War: and it is for this reason that we make a place for it here. It opens with a striking account of the funeral of a soldier who died in a village hospital early in the war; then it tells of the training of the soldier at the army depot, and in wretched villages near the front; then we follow the man to the trenches where he is facing not so often the enemy as the quite important problems of procuring meals. and of the care of uniforms and arms; then again at each new resting place the seeking for billets; at the end only we hear of alarms (not of spec-

54 In 1918 Delvert published another volume. Quelques Héros, Récits authentiques de la Grande Guerre. 
tacular alarms), of offensives (of the same character), and of removal to the hospital at the rear of the fighting line. The long preface in which the author states his desire to correct the entirely wrong impression which the public has received of the meaning of trench warfare, is apt to prejudice one against the book. . . There have been so many books written with the purpose of giving at last to the poor deceived reader the "true story"! This time, however, the claim is not without justification: that account of life in the trenches, deliberately setting aside all hair-raising stories, was in 1918 something really new : it gives a background of reality to all the other war recollections we may read. It may seem comparatively terse reading, but the author has successfully avoided that not uncommon tone of indifference to danger and to suffering which savors a little of affectation $: 5$ as well as the sulky tone of the

55 As an example of this we could quote Jacques Fierre's 80,000 milles en Torpilleur (1918). It is the best of those books which represent the soldier of the great war as bearing cheerfully-too cheerfully-his crushing burden. We do not like the actor in so grim a drama to make light, or to pretend to make light of his task. Fierre enjors relating such humorous incidents as their mistaking a sea-lion for a torpedo, the receiving of a wireless signaling their own craft as an enemy boat, attempts of steamers to ram them in the belief that their 158 


\section{PERIOD OF DOCLMENTATION}

obscure heroes who, more deserving than many others, have nevertheless received no recognition in the form of medals. The title admirably expresses the whole idea of the book: "Tenir.'

A book combining the features of both Delvert and Buteau, and one which ought not to be passed without notice, is Raymond Gentry's $L a$ Flamme Victorieuse (1917). The spirit is excellent; it is equally removed from false modesty and from the suggestion that the horrors, that the author has lived through, beggar deseription. Gentry does not strike attitudes; lhe is sometimes humorous, sometimes pathetic, but manly always. By profession he is a Paris journalist, and a writer of no mean ability. He has some delightful sketches of types, the best of which is Nenesse, the plumber of Montparnasse, a splendid duplicate of Gaspard, the snail vendor of Montmartre.

little torpedo destrover was a German submarine. The diffieulty of running down submarines is, however, well described.

Something of the same tone is apparent in Emile Henriot's Carnet d'un Dragon dans les Tranchées 1915-1916. Henriot is an editor on the staff of the Temps, and the author of A quoi rêrent les Jeunes Gens (1913). After eleven months of warfare he feels disappointed because he has not seen any real figliting: "It seems strange, when I think of it, that I should bave been eleven months in first line trenehes,-and not always in the best places-without having had a single opportunity of using my rifle." 


\section{* * * *}

As so many of the books which have already been discussed, and many more of those which are mentioned later, refer to the Marne and to Verdun, it might be well, perhaps, to group together here the names of a few of those which deal with the fighting in Flanders, where the victories were not achieved by the French arms alone, as was the case at Verdun, although they contributed a large share to them. We place at the head of that group the book by, Lieut. J. Pinguet of the French wary: Trois Etapes de la Brigade des Fusiliers Marins-La Marne, Gand, Dixmude (1918). It relates the heroic 'deeds of the Breton marines, who, like the "chasseurs," made a very glorious name for themselves during the great war. Pinguet tells how these 6,000 men kept at bay, for months, troops which outnumbered them in a proportion of ten to one. Charles Le Goffic had previously described the fighting at Dixmude. But while his description, which is as beautiful as a legend, ${ }^{56}$ and worthy of his sturdy heroes, he did not

$56 \mathrm{Ch}$. Le Goffic, Dixmude, Un Chapitre de l'Histoire des Fusiliers Marins ( $\gamma$ oct.-10 nov. 1914). Steenstraete, Un $2^{\circ}$ chapitre ...St. Georges et Nieuport, suite et fin ( 3 vol. in all, $1916 \mathrm{ff})$. See also the fine book by G. Le Bail, La Brigade des Jean le Gouin; Histoire documentaire et anecdotique des Fusiliers marins 


\section{PERIOD OF DOCUMENTATION}

live that legend, whereas Pinguet did. In fact the works of Pinguet and Le Goffic complete each other: The one relates the fighting as a whole, as seen by Admiral Rornach, the eommander-inchief of those remarkable troops, the other tells of the work of separate units which typify all the others. One will obtain a better understanding of the "gigantie" struggle by realing Le Goffie, and of the "heroie" struggle by reading Pinguet. Note that Pinguet does not speak only of heroic resistance, he relates moments of weakening also, as, for instance, that day when his men really wanted to give up; so while Pinguet is less consistently epic than Le Goffic, he is more tragically true.

As a complement to these two books, one might read Marguerite Baulu's La Retraite d'Anvers et la Bataille de l'Yser, to which M. Vandervelde contributes a preface (1918). This thick volume tells of the part which the 48,000 Belgians had in the battle of the Yser, where they fought side by side with Admiral Rornarch's marines. It is a conscientiously written reconstruction, with maps and drawings, of the whole moving drama of the Belgian army, which

de Dixmude (d'après des Doeuments originaux et des récits des Combattants) (1917). 
ended when the flooding of the country came to the rescue of the Allies. The "inside" story of the Belgian army has been told in Mon Journal de Campagne, by Robert de Wilde, a Belgian artillery captain at Liège and on the Yser (1918).

* * * *

It is a remarkable fact that at the conclusion of the reading of each of these war diaries one is inclined to say: this is positively the best of all those I have read so far. Is this due to a simple phenomenon of displacement of former occupants by the last occupant of the mind, or is it, perhaps, because one's admiration increases with each new account of the splendid achievements of the soldiers of the great war, and that one's emotions are keyed up to a higher pitch by each successive reading? The present writer does not pretend to be able to offer any definite explanation. But this he knows, that if he were asked to point out the diary which has left the deepest and most lasting impression upon his own mind, he would unhesitatingly reply: Erlande's En Campagne avec la Légion Etrangère (1917). It is the one which, from all points of view, appeals most to our human selves in their entirety; because, although it is a war diary, it never fails to give a large place to the 


\section{PERIOD OF DOCUMENTATION}

man as man and as distinct from the soldier; because, too,-owing to the speeial way in which the Legion is recruited-one feets here more than anywhere else the moral self-determination of the men, for they are all volunteers, and in no ordinary sense of the word. They are, for the most part, men who are not French by birth, but who wish to fight for France, men who withont any moral or other compulsion, have coolly and deliberately eleeted to serve France, for reasons of their own. We prefer Erlande also beeause-why should one hesitate to confess it?-because of the splendid virility which his men manifest in big spectaeular achievements. There is in that faet something which satisfies the mind, that harmonizes with our sense of the fitness of things. There is a shocking disproportion or lack of fitness when men of only average personality express themselves in actions whieh seem grand; this, we feel, is melodramatic; but there is also a lack of fitness when truly heroie souls have to express themselves through tame, eommonplace events; now these men of the Legion being splendid personalities, it pleases us that opportunities should be afforded them of expressing themselves in acts of splendor. 
The official account of the achievements of the Volontaires Etrangers during the war will be written by M. Emile Roux-Parnasse. He will have more to place on record than Erlande, but however large his catalogue of deeds, it will never have the true ring of Erlande's personal account. The unit whose deeds he records, is Battalion D, of the 2nd regiment of the 1st Legion, and more especially Company D2 of that Battalion. Battalion D ceased to exist as a unit a few weeks after that terrible attack of May 9 th, 1915, on account of the numerous deaths among its members, including that of Major Muller, its glorious commanding officer. It was. Muller who had mustered and trained the recruits at Avignon in August, 1914, and it was with sincere conviction that those men would sing :

C'est nous la Légion,

Baïonnette au canon,

Qui venons combattre aree la France!

As a collection of psychological documents this book is far more substantial than many novels of the once famous realist school would be if rolled into one, although that school claimed to draw its chief interest from "scientific observation and documentation." Such a wealth 


\section{PERIOD OF DOCUMENTATION}

of characters,-if we may use that popular term, -will be found nowhere else: there are sons of bourgeois homes, unfrocked priests, members of the aristoeraey, foreign princes, nihilists, crooks, students, painters, daneers, Jews, political exiles, men of 50 and boys of 17 ; there is Xavier de Carvalho, son of the famous Portuguese pamphleteer; Crant, the English artist; Gourfinkel, the Russian student, a thoroughgoing radieal-socialist, and at the same time an incorrigible aristoerat in thought: there is also Père Charles, the loquacious sergeant, as prodigal of daring deeds as of picturesque language. Let us pick out two typical sketches of these men : "Sergeant Glorian has recently been made quartermaster in D2 Company. He is fairhaired, wears a earefully trained mustache, and has blue jolly eyes that twinkle behind the glasses of his pince-nez. In eivil life he was a theatrieal manager. He had staged at Brussels and at Paris the 'Merry Widow,' and 'Maltz Dream,' and various other light operas which he knows by heart. The others say of him: 'Glorian! he is always full of go, always jolly! his morale is perfeet!' Glorian replies that he had got poisoning of the blood in the theater, that he has come to the war to rest, to build up 


\section{FRENCH LITERATURE OF THE GREAT WAR}

his health, and that he has made up his mind never to have the blues. ... He is the most magnificent toper of the company. He has interesting comments to make upon the newspaper reports of the front; he has also many good stories to tell and he improvises to the waltz tune from the Merry Widow.

O paille pourrie sur laquelle on s'étend,

Cadarres de rats qui puez au printemps,

Os de côtelettes

Poux de Quatre Cent Vingt

Propreté parfaite

O quel séjour divin.

The name of the following character is not given. "In front of a restaurant an adjutant is pitching into a man in a most magnificent style. The man is a strange looking fellow: short, thickset, pink all over; he listens to the adjutant in silence, his head a little to one side, his finger tips joined together, his eyes turned heavenward. The adjutant having brought his remarks to a close, the 'légionnaire' heaves a sigh and says: 'How can you treat in that manner a man who still has the power to bring God down from heaven at Holy Communion? I am in Holy Orders . . . and I am a victim of love!' "Grant invited him to empty a glass and 


\section{PERIOD OF DOCUMENTATION}

asked him to relate his story. IIc was a priest. At 25, he seduced one of his penitents, who soon afterwards abandoned him, and he enlisted in the Légion.

"-Twenty years of service!-

"And drawing from his pocket his colonial service medals :

" "Here's my tinware!'

"And until roll-eall he continued telling anecdotes enameled with Latin quotations. In his satchel he had a copy of Mareus Aurelius: 'It's all there,' say's he, 'I never read anything else' ', (p. 273).

The opening chapters of the book tell how these various elements were made into a coherent military unit. The explanation is psychological and rather difficult to give. It seems almost as if, because they are heterogeneous, and because no one would think it possible for them to submit to miform discipline, they are determined to show what they can accomplish. Their esprit de corps is the result of a kind of wager, a triumph of the will. "It is a secret discipline," says Erlande, "it appeals not to the sense of duty, nor to fear of punishment, but to a proud self-respect (amour-propre et ficrté).' It is a combination of traditions, more efficient than 
the most rigid rules, a "loi d'orgueil," a tacit understanding, and, so to speak, a "moral uniform." But it matters little how the result was attained, the fact is patent that "in no other formation was the esprit de corps so living a reality," and that miracle of implanting the spirit of the Legion into new recruits in August, 1914, was the work of one month.

Each company of the battalion, however, developed a special character. D1 was the "model company," in which military correctness prevailed; D2 was the "electric company"; whenever some unit broke a record, D2 at once outdid it; D3 is the "happy company,"-when everything is as it should be, why, all is well!--D4 is a duplicate of D1.

"Now they are ready. Every man knows what he owes to the flags of the Legion: nover to look backuard, never to retreat to save his life. The wine is drawn, it must be drunk" (p. 98).

Such determined men must have leaders worthy of them. And they certainly have! Junot, for instance, the captain of the "electric company,"'-“Junot," said an African veteran, "I know him! He's the very thunder of God! $\mathrm{He}$ is as rich as Crœsus, and loves nothing but war, danger, adventures; he's a soldier, first 
and last, a soldier and that's all! He has fought wherever there was fighting to be had. He's the best cavalryman in the French army. And as for a marksman! He can kill a flying pigeon with his revolver, and knock a hole through a penny pieee at 50 yards. And with all that he is as brave as they are made. With him it's a pleasure to go into it, but, hegad, you mustn't show funk! As for him, he doesn't care a damn; he's armor plated, he can go through anything! ${ }^{5 i}$

The Legionnaire is a proud fellow as the following short deseription attests: "When he must work with piek and shovel, he does so, but grouching (en rouspétant),- - for the fellow must be a blatant ass (dingo) who regards shoveling earth and mud a whole night long as something entertaining. When he must fight, the Legionnaire fights, but with a happy smile! When there is neither working nor fighting to be done, he wants to be satisfied, i. e., he eats well, he drinks well, and he sleeps well."

The following describes the moment at which an attack is going to be launched.

57 For Junot, read Junod. He was of Swiss origin, born in Genera in 1975, and was killed Sept. 28, 1915, during the attack of the strongholds of Souhain. His Lettres et Souvenirs were published in 1918. 


\section{FRENCH LITERATURE OF THE GREAT WAR}

"The men are lined up behind the parapet. . . There is perfect silence in the trenches.

"One single thought occupies the mind of them all: The attack must be brilliant. There are no jokes flying about, there is no boasting, nor any of those sublime utterances; words which, in all probability, have never been uttered; words invented at the rear by those who make their living by writing with their slippers on and their bellies full, and the comfortable thought that it is sublime that others should die....' (p. 235).

There is one episode in the book which is truly sublime. It is the attack of May 9th, 1915, during the battle of Arras, a magnificently heroic, but frightfully costly charge. The Legionnaires took in succession the Chalk Pits, la Targette, and Neuville Saint Vaast. The excitement of reading those pages leaves one breathless. One must bear in mind that every man who took part in that charge knew what it must cost, and that only by the greatest good luck could he come out of it alive. But they went with splendid composure to that "orgy of heroism."

A short fragment from the description of that charge will enable the reader to form an idea of what it was. 
"Battalion $\mathrm{C}$ is on duty at the listening posts.

"In front of the barbed wire entanglements, Major Moiret, the father of the Poles, falls with a bullet through his heart. Upon him the same machine gun. salve piles up, Brigadier Van Mengen, a Belgian of 50 years of age, Corporal Onegger, of. the hospital service,--a Russian student; the Greek stretcher-bearer, Theodokis. Alongside of them, Neuflagel, a Polish army doctor, is breathing his last with two bullets through his kidneys.

"Battalion D follows Battalion C.

"Between the lines, Najor Muller, struck in the liver, drops and dies. Near him, Quartermaster Sergeant Glorian and Sergeant-Major Nagel fall dead. At the moment of leaping into the German treneh Captain Jumot receives a bullet through the chest.

"Wearing his overcoat, a rifle with twisted bayonette in his hand, his arm bleeding, his face damaged by a blow from the butt end of a rifle, yelling and magnificent, littlc Lieutenant Vivès runs forward like a madman and finally drops in a faint. His friend Lientenant Gougeux is among the dead. . . .

"In a shell hole, Père Charles, whose thigh is broken, calls for the stretcher-bearers; a little 
further, Sergeant Ostache is lying on the ground, ... then Sergeant Dones...t then the Armenian Sergeant Manoukian. . . .

"Lieutenant Ceccaldi calmly leads out the sections of Company D2.

"Near the spot where Majors Muller and Moiret are lying, drops Major Gaubut of Battalion A'" (p. 239).

It seems as if they were all killed, all those with whom we had become acquainted through the previous pages, and yet, what was left of them still pushed ahead: "But the companies advance. The defenses of the Chalk Pits are carried, then la Targette ... then we attacked the hardest position of all, Neuville Saint Vaast, though we were not completely successful on that occasion."

Indeed, if ever there were brave men, these were surely they, and Erlande may well say of them: "All these men, in their dull uniforms, are heroes more splendid than those of Friedland and Rivoli. Those who were there and saw them know it. As for the others . . the others have only to keep quiet, to bow their heads and to believe"' (pp. 237-8).

After such accounts of what actually took place, the erudite psychological studies of the 


\section{PERIOD OF DOCUMENTATION}

soldiers of the Great War pursued by weighing, measuring, hair-splitting "psyehologists" like Bonnet, appear ridiculously small.

The faet that most of those men were not French by birth matters not at all. The criterion of blood for the classification of living species has its utility in the case of animals and of lower human beings, but the qualities that these men displayed are of a higher order and a moral criterion is here to be applied. One needs no more French blood to be truly French than one needs Greek blood to be a Stoic or an Epicurean. It is one of the finest tributes to France that so many claimed to be Freneh in soul, who could have no physiologieal claim to that distinction. The very first month of the war, August, 1914, was not yet over before men of 52 nationalities had asked for enrollment in the Foreign Legion: 8,000 Italians moved by the spirit of Garibaldi, 4,500 from the Swiss republic, almost 4,000 Russians, 300 Greeks; nay, 1,000 Germans and even more Austrians; many. of eourse, from Alsace-Lorraine, from Belgium and Serbia; Armenians, Syrians, Czechs, ete.; many also came from the United States of America and from Canada. On August 21st, 1914, 20,000, already equipped and ready to 
march, were reviewed by French generals on the Esplanade of the Invalides.

* * *

In 1918, published war diaries were already very numerous. Gabriel Tristan Franconi made an interesting attempt to renew the "genre" in Un Tel de l'Armée Française (1918).

Instead of emphasizing the individual characteristies of this or that soldier, the author of Un Tel (So and So), obtains a picture of the soldier, by rejecting all accidental elements of individual men,-what some might call the personal picturesqueness,-and keeping only such elements as are common to all. In terms of mediæval philosophy, he would be classed as a realist, as contrasted with the nominalists.

There is one restriction, however; what Franconi pictures is not the French soldier of all times, but the French soldier of the Great War. Apart from that, $U n$ Tel is a general type: $\mathrm{He}$ is an intellectual, and an intelligent man of no special culture; he is a Parisian and also a man from provincial France; he is a man of refined tastes and one of sensual desires; he belongs to the higher walks of life and also to the lower. And if one asks: What makes him particularly the man of the Great War? the answer is: $\mathrm{He}$ 


\section{PERIOD OF DOCUMENTATION}

has been morally tempered by the great experience and is rendered thercby utterly different from the man in uniform who remains in the rear, and from the civilian who tries to do his share by paying commonplace compliments to the man who returns from the front.

That abstract type once conceived and created by Franconi, we go through the usual sequence of events: $U n T e l$ in the mobilization camp; $U n$ $T e l$ at the front, in an attack; $U n T e l$ wounded and taken to hospital; then comes the indispensable,-but always eharming,-picture of the nurse and her tender eare for the wounded; then we have the visit of the convalescent to his home, and his return to the front. An original feature, however, is to be found in the description which Un Tel gives of the surprising changes which have taken place in the army during the short time of his absence from the front. The army which fought the first part of the war has given place to a new one, as a consequence of the intense and rapid work of adaptation of mechanical devices to war conditions: new equipment, new guns, tanks, etc., etc., and a large variety of deviees to protect the lives of the men. In a word, he "discovers" the army which is to fight the second battle of the Marne. 
Franconi gives some vivid pictures such as Histoire d'une Fourragère, or the recapture of the famous Hill 308, which finally relieved Verdun (pp. 134-149). There are a few cleverly drawn individual soldier types (Pote, Tap-Tap), which relieve, by a welcome note of real life, the impersonality of $U n$ Tel. Franconi also makes some clever and interesting remarks concerning soldier's slang. (Exégèse de certaines phrases militaires.) But even with these features, $U n$ Tel remains a war diary of its own kind, which offers a complete contrast to a work such as Gaspard. Gaspard is one individual through which the reader grasps,--or thinks he can grasp, -the idea of the general type of the French soldier; $U n T e l$ is the description of that general type through which the reader is supposed to see the elements of all the individuals: Gaspard and Bourru, Blue Devil and Legionnaire, infantry, aviator, etc., etc.

For the average reader, the first type, Gaspard, is alone interesting, because $U n$ Tel is an abstraction. Franconi ${ }^{58}$ himself must have been conscious of that fact, and that is probably the

58 Franconi is also the author of a pamphlet, Bisbur au Democratic Palace, which is a description in a satirical vein of military hospitals. Franconi gave his life for his country. 


\section{PERIOD OF DOCLMENTATION}

reason why he introduced here and there eertain eonerete individuals. For the thoughtful reader, the abstraet type is as interesting as the conerete, because he is intelligent enough to generalize from the ease of Gaspard, or to imagine the eonerete and particular, from the description of $U n$ Tel. At the same time, even the intelligent reader would probably derive more pleasure from the conerete, because of the "life" in it.

* * * *

During the fourth year of the war the number of war diaries had so enormonsly inereased, that a book of that kind had to attain a very high degree of excellence to attract any attention. Franeoni had been only partially successful in his attempt to break away from the usual style; the last soldiers' book which we propose to discuss, owed its snceess even at this late date, to sheer exeellence. We cannot afford to pass it by. The Mémoires d'un Engagé l'olontaire by Binet-Valmer, citoyen Genevois (Paris, Flammarion $)^{59}$ is another volume to set in opposition to Barbusse. The record of this volunteer was indeed brilliant. Starting as an escort dragoon, he soon was made a 2 nd class cavalryman, then

59 First published serially in Le foumal. 
section color-bearer, then non-commissioned officer, lientenant, and finally officer in command of a group of tanks. He was awarded many honors; from the military cross, to that of being mentioned in the Order of the Day of the whole Army. He was a Genevan by birth, a descendant of Hugnenots, and very early in life he felt a longing to return to the country of his ancestors. He therefore went to Paris while still a youth in his teens, and there established his reputation as a brilliant writer. $\mathrm{He}$ was made a Knight of the Legion of Honor after the publication of such books as Les Métèques, Lucien, La Créature. When the war broke out he was absolutely ignorant of the soldier's life and of a soldier's duties, for he had left Geneva before being called to the Swiss colors. He nevertheless determined to take part in the war, and being one of those men who always manage to get what they want, he succeeded (by deceiving the authorities) in getting enrolled in a French regiment. He fought without training, and he fought admirably. His sonl delighted in all the terrible glory of the battlefield. No writer has so well as he the power of taking the reader with him into the thick of the fight; of making him hear the racket of the machine guns, 


\section{PERIOD OF DOCUMENTATION}

and the booming of the eamnon or the groans of the wounded and the dying, or making him see the headlong tumble of the stricken horsemen. Well may Mauelair say of him: "He has been everything, has known everything, has suffered everything.'"

He also lived through those hours of darkest tragedy after the eapture of St. Quentin by the Germans, and before the first battle of the Marne. He knew, therefore, the physical and moral exhaustion of the disorderly retreat, and shared with other men the idea that the end of everything was nigh; but his spirit remained undaunted, and he determined to go under, if need be, with the whole army, with France, and with civilization, but never to yield to the treacherous, barbarous, monstrous power of imperial Germany. His explanation of the miracle of the Marne is well worth any that has been given. "I was in the line, I understood nothing therefore of the tacties, but after Charleroi I found myself with men who were in headlong flight:

It was those same men who suddenly refused to retreat any further, and who, not knowing that they were going to win, held on, each in his own place. The miracle was in the heart of each soldier. All was lost; it was going to be another 


\section{FRENCH LITERATURE OF THE GREAT WAR}

1870 ; but that must not be! France was going to die; but not one of us wished to survive her, and so we raised her from the dead."

After the Marne, a new kind of torture awaited him; it was that of the unending inactivity of the trenches. An energetic man such as Binet-Valmer suffers more from inactivity than others, and yet we find in this part of his diary nothing that reminds one of the moral depression of Barbusse's men. It is certainly not that he has hesitated to tell the whole truth, for his Lucien proves pretty conclusively that he loves the "whole truth" and dares to speak it; we are therefore led to the conclusion that the state of mind deseribed by Barbusse did not exist. As to Binet-Valmer himself, instead of settling down in the trenches to whine or to write a tragic account of them, he keeps active. Noticing that machine gun crews are more active than the infantry, he has no rest until he is permitted to enter a military school for the training of auto-machine gunners for the cavalry. But his luck abandons him for a time: he is never at posts where actual fighting takes place : even when he is transferred to the Verdun front he is not fortunate enough to repeat his experience of the Marne. Meanwhile, he be- 


\section{PERIOD OF DOCLMENTATION}

comes enthusiastic over the deeds of his comrades. It is with delight that he greets the new weapon: the tank: the "artillery of attack." $\mathrm{He}$ witnesses the foolhardiness of the men in charge of those machines which at first gave little in the way of results but were full of promise. He therefore enters the tank corps on January 17th, 1917, and after some time is placed in command of three whippets (sangliers). It was during his first battle, the rictorious attack at Malmaison, near the Chemin des Dames, that he was wounded. Ie takes adrantage of his confinement in hospital to write these Mémoires.

To those who would understand why the French were victorious, this book will bring abundant information.

With Binet-Valmer we close the list of the leading war diaries by soldiers.

* * *

With the exception of a note on Jacques Fierre's 80,000 milles en Torpilleur, we have made no mention so far of books written by sailors.

The army played of eourse an incomparably greater part in the war than the nary, and that is sufficient to explain the far lesser number of books dealing with naval warfare. 
The best known of them is René Milan's Les Vagabonds de la Gloire (in three series, $1916 \mathrm{ff}){ }^{60}$

The excellent spirit of the French navy is beautifully set forth in those volumes, and were it only to learn how the sailors did their duty, how eager they were to do it, the volumes would be well worth reading. If more glorious or more spectacular deeds are not reported, it is simply because the enemy gave the sailors no opportunity to perform them.

Milan is an excellent writer.

But there is another book by a sailor which has so special a message to deliver, offers so much information upon a little known aspect of the war, and is so absorbing in tragic interest, that no one can afford to leave it unread: Odyssće d'un Transport Torpillé by $\mathrm{Y}-$ (1918). Large fragments had already appeared in the Revue de Paris. ${ }^{61}$

It tells in a series of letters addressed by one of the officers to a friend of his who is serving on

60 The first volume alone is entirely devoted to the navy. The second, Trois Etapes, deals partly with hydroplanes; and the third, Matelots aériens, gives an account of the part played by the dirigibles of the Allies in the second part of the war.

is The value of this book was very quickly recognized in other countries than France. Houghton Mifflin and Co. lost no time in issuing a translation.

182 
a war eruiser the story of the I'amir, a merchant vessel of 3,000 tons which the French grovernment requisitioned immediately the war broke out, and for the use of which it paid the owners 1,000 franes a day.

The letters, written in a vivid, yet sober style, explain admirably, but without the least snogestion of boasting, the immense share which the merchant navy hat in the wimning of the war by transporting not only troops and arms, but victuals, timbers for the trenches, coal, shelters, and a thousand other things necessary for the earrying on of the war. Ever on the way, or hurriedly loading or unloading, that vessel.-one of thousands similarly engaged,-saved the Allies from a crushing defeat. The book grips and holds the interest of the reader, even though there are no showy uniforms, no flags, no gums, no speetaeular seenes of any kind. Two men elaim our attention: Captain Forgues, and his mate, $\mathrm{Y}-$, the anthor of the letters. They are both striking types of French sailors, who, from the first day of the war, do their duty. and more. Y- is a young man: he is engaged to be married, and, as the war goes on month after month, he finally takes advantage of a furlough to marry. IIe is supremely and disereetly 
happy, he has just received word that the crowning happiness is to be added to the first-that of fatherhood,-when everything ends abruptly. Germany has just started the ruthless submarine warfare, and the Pamir is one of her first victims; she disappears leaving no trace whatever.

$\mathrm{Y}$ - never indulges in patriotic talk nor in any other form of sentimentality; his book is one of the most virile, sincere and sober ones of the war; and yet, this man who does nothing whatever to solicit our sympathy, who would, indeed, resolutely set it aside, has more than any other the gift of calling it forth.

But our sympathy and admiration for the man of duty is darkened as we read on and gradually come to realize the injustice of which he and many of his comrades in the merchant service were the victims. A tragic contrast between Germany and France establishes itself in one's mind: a contrast which it hurts one to admit, but which the circumstances related in this book thrust upon one with irresistible force. It may be expressed thus: In Germany there is a remarkably efficient government to protect rascals or moral dunces like those who allowed themselves to be ordered to commit unspeakable atrocities; in France, there is an abominably 
careless and inefficient government which leaves without protection men as noble minded as can be found anywhere on the face of the earth.

On land, for the army, something was done, as the seeond Battle of the Marne shows, but on the sea a costly negligence prevailed.

The men in office met the demands for proteetion which these men who had seen with their own eyes and who had experience, ventured to make, by the ineredibly naïe refrain: "We tell you that there is no submarine menace: do not our newspapers say so? There is no submarine danger!" Neanwhile, the sailor's who knew how they might be saved, realized at the same time that they would not be. The heart siekens at the thought of all the suffering endured by those noble fellows, and all the needless sorrow that was brought to their homes, by the eulpable indifference of those miserables slackers in office. For what were the demands of the sailors, after all, that they eould not be met? Wireless apparatus and guns. whieh might have been supplied at relatively little cost!

It was only after February, 1917, when it beeame evident that the fate of those on land depended upon the safety of the seas, and after a large number of brave seamen had been lost with 15.5 
their ships, that the government began to bestir itself.

The book, though not intended as such, is a terrible indictment of the allied governments, and particularly of the French.

If it is right,-and, surely, no morally sound person will care to deny it!-that the Kaiser and his aiders and abettors be arraigned before a world-court on a charge of ordering and organizing piracy, it would be right also to bring to judgment those French officials who did nothing to thwart the criminal designs of the enemy. This book ought not to be forgotten now that the war is over. Public opinion all the world over, if enlightened by it, could be brought to bear upon France to force her to better her own government for the sake of her splendid seamen. ${ }^{62}$

62 We quote below in the savory French of the author a few cliaracteristic statements:

"Arrange comme tu voudras. la France a besoin du monde entier pour gagner sa victoire, et comme il n'y a pas de chemins de fer pour aller en Australie, en Argentine ou aux Etats Unis, ni dans aucun autre pays qui nous refilent de la matière première, on était bel et bien cuit sans la marine marchande" (p. 241).

"M'est avis que Mousseux (a seaman on board the Pamir) pense aussi que si nous gagnons la victoire sa ne sera pas faute de lui avoir tourné le dos. . . Il pense comme nous, et l'on est vite tombé d'accord que la marine marchande est quasiment offerte aux sous-marins boches et que şa durera ce que ça durera" (pp. 202-203).

And elsewhere: "Dire qu'un pays comme le nôtre cu 186 


\section{PERIOD OF DOCLMENTATION}

It would be interesting, at this juncture, to compare the recollections of the soldiers of the FrancoPrussian war with those of the soldiers of the Great War. This eannot be done in detail here. Let it be said, however, that one cannot but be struck by the - similarity of their experiences. The main difference lies in that the Franco-Prussian war having lasted practically only a few weeks, while the Great War lasted almost four years and a half, the hardships, the discouragement, the inconceivably brutal behavior of the Germans, could, in one ease, be forgotten more rapidly, (except by the comparatively few who were directly affected), whereas in the last war, the fact that such things kept on for so long, impressed thein much more deeply upon the mind of the world.

We knew something about the sufferings caused by mistakes of the higler command and the poor organization of the commissariat and of the sanitary corps, because Zola, in La Débâcle (1893), and the Brothers Margueritte in Le Désastre (1903), had reminded us of them. But a perusal of the personal recollections of the soldiers of 1870 , in the light of what the present war has taught us, will eause us less astonishment than would have been the case some years ago.

tout le monde se fait casser la margoulette en riant, est traité de la sorte pour couvrir une bande d'imprévoyants! C'est a rire jusqu'au jugoment dernier" (p. 229).

And there are pages in which he shows that everywhere "les routes secrètes sont des routes de desastre, car toujours les Allemands, par leurs espions, sont renseignés (he gives several heartrending instances). Aussi Fourgues n'êchappe si longtemps que parce que il ne va pas dans ces routes secrètes" (p. 205). 
In 1870 , as in this war, the witness is impressed by the splendid fighting qualities of the French soldiers: not only by their dash, but also by their endurance under the most trying circumstances. In reading, for instance, the stirring book of Ludovic Halévy, L'Intasion, Souvenirs et récits (1S72), one becomes aware of the fact that the circumstances which accompanied the defeat of the army in 1870 , were as trying as the gloomy days before the Marne and the endless waiting in the soaked and filthy trenches.

We would advise the reader to turn also to Amédée Achard's Récits d'un Soldat (1895), and, in that book, more particularly to the passages which illustrate the fundamentally barbarous nature of the Germans, and which suggest striking parallels between $18 \% 0$ and 1914. Reference has been made above to the wanton destruction of scientific collections in 1870; in 191t, they specialized in the ruining of industrial implements, of trees, and of churches; it was the same lack of culture. Achard had occasion to witness in 1870 their lack of selfrespect and of humanity: He had served as a volunteer, in the army of Sedan and saw how littie attention the Germans showed to the white flag. "The flag of truce hoisted by us on the ramparts did not stop the attack, but only prevented us from going on with the defense." It was the same principle, only carried a little further, that permitted the Germans to make use of stretchers borne by men clad in Red Cross uniforms, to bring up, free from molestation, machine guns which they used to win fort Douaumont. One should read also, in the same book, the story of the 188 


\section{PERIOD OF DOCCMENTATION}

prisoners of Sedan when they were herded together in the peninsula of Glaires, (formed by a curve of the Meuse), and there allowed, or rather condemned, to die of hunger, being subjected meanwhile to the worst insults from unehivalrons officers. Achard limself was, as a great favor, taken witl a eontingent of prisoners and deported into Germany. The story of this jomrney of starving men traveling under eseort, is one of the vilest banditism. Even the wounded were not allowed any food; when they lagged belind, they were driven forward with the butts of rifles, and when they gave out completely, they were mercilessly slot. The heart sickens in reading of such ignoble behavior. They had not changed, except for the worse, between 1570 and 1914: would it not be naïre to expect that they will change after 1918? ${ }^{63}$

\section{Non-Combatants and the War}

Our account of War Literature would be incomplete indeed if we did not devote some pages to books dealing with the effects of the war upon the civilian population.

That non-combatants had their share of trials needs no proof. The legend of Forain's famous cartoon has expressed it admirably: "Pourvu qu'ils tiennent! Qui ça? Les civils." (L'Opinion, Jan. 1915.)

63 Some instances of German cruelty during the Franco-Prussian war, were familiar to us through the writings of Maupassant and of Daudet; but treated as fiction, they failed to carry conviction. 


\section{FRENCH LITERATURE OF THE GREAT WAR}

Let us consider first of all such books as tell us of the civilians who were caught up in the maelstrom of the war. Later, we shall deal with books describing the civilians in the rear.

Civilians of the war zone on the Allies' side of the battle line, have been described in Emmanuel Bourcier's pleasing little book Gens du Front (1917). Bourcier gives us charming sketches of village life near the front during the days of intermittent shelling by the Germans, and until one day every house was leveled to the ground by heavy bombardment.

One of the best books of the war,-best with regard both to style and to content,-is Isabelle Rimbaud's Dans les Remous de la Bataille (Charleroi, the Marne and Rheims) (1916). The author is the sister of the famous poet Arthur Rimbaud, ${ }^{6+}$ and she gives a very vivid and yet sober account of the débâcle of the civilians fleeing before the Germans in the dark days of August and September, 1914. The first chapters picture the effects of the mobilization upon the peasants. $^{65}$ Then came the days of emigration,

64 Her home was at Roches, a village in the Ardennes. 65 We have many pictures of the state of mind of the Parisians (and of the habitants of other large towns) during the early days of the war, and amongst them, Marcelle Tinayre's, in her novel, Teillée des Armes, which is a very worthy counterpart of this work. 


\section{PERIOD OF DOCLMENTATION}

the eontinuous flow of refugees. The author joins the sad proeession and tells of her experienees until the day when she suceessfully brings her siek husband into Paris.

Those who like to make comparisons will undoubtedly find it interesting to establish one between this book and another of a similar kind, viz., Madame Huard's famous My Home on the Field of IIonor. Madame Huard, though French by marriage, is an Ameriean by birth, and while she feels deeply for the poor suffering people whom she saw, the chief impression which the book leaves is that of the energy and resoureefulness of that remarkable woman in every trying emergeney. The impression ereated by Isabelle Rimbaud's book is very different. She has as mueh eourage and initiative as Madame Huard, but as one turns over the last page of her book, one is eonseious not so mueh of a feeling of admiration for the author, as of an immense Christian sympathy for the innocent, helpless vietims of the war, and a saered horror like that whieh the aneients had of blind, remorseless Fate.

There were also eivilians who underwent the hardships of war on the other side of the battle 
line; and their lot was worse. The full story of their sufferings has been published gradually as towns and villages were freed of the invaders, and when there was no more danger of bringing on reprisals on French prisoners in Germany: that is, since the armistice. But even during the war some books came out which were eagerly read. The reports of Commissions on German barbarities and atrocities, eloquent as they are in their bare statements of facts, lie outside of our study. But we can mention a little volume which has been translated into English and has been much read in America; we refer to Marguerite Yerta's Les six Femmes et l'Invasion, Aout 1914-Février 1916 (1917). The six women whose husbands were fighting for France, remained in their town, daring to face the humiliations of the vanquished. They felt certain, however, that the German successes were only temporary, and they acted accordingly, retaining their dignity in spite of their unfortunate destiny. ${ }^{66}$

66 Under this heading we should also place the following accounts by women: H. Célarié's Sous les Obus, Journal d'une jeune Lorraine, (1914-16), with illustrations; Madame d'Urville's Filles de Metz, (1919); Madame Leune, Tels qu'ils sont, Totes d'une Infirmière de la Croix Rouge. Madame Leune was for a time in a hospital behind the German lines, at Lille; later she suc192 


\section{PERIOD OF DOCUMENTATION}

Certainly one of the most illuminating doeuments of the war, one which easts a flood of light on the suffering of the people in the invaded regions, and on the really barbarous mentality of the Germans, is the little volume: Le Vartyre de Lens, Trois années de captivité, by Emile Basly, deputy mayor of Lens (Plon, 1918).

The author had started life as a miner in "La Ville Noire"; he was a soeialist and had been elected mayor of that town of 40,000 inhabitants. He writes very modestly of the share whieh he had in keeping up the "morale" of the population, and one guesses that he did a great deal more than he has reported. He warns his readers not to look for literature in his memoirs. And yet what he produces is the best kind of literature; one which, though dispensing with artificial adormments, goes straight to the heart.

It would be difficult to write in a more sober style; every line bears the impress of truth. After each chapter, one is inclined to repeat the word so often heard from those who witnessed the eourage of the French civilian popula-

ceeded in reëntering France by way of Switzerland; Madame Emmanuel Colombel's Journal d'une Infirmière d'Alsace. She also was caught by the invasion in her hospital in Arras during the short occupation of that town by the Germans. 
tion during the stormy days of the war, "Les braves gens!" Few crimes of a sensational character are reported as having taken place during the first two years of the war. ${ }^{67}$ But how cruel was the moral torment of being forced to put up for weeks, months and years, with vexations from an arrogant, and stupid foe! Those brutal soldiers would come and demand anything and everything that they fancied at the moment; underwear, watches, shoes, clothing; one of them even demanded a mandolin; several second-lieutenants particularly wanted "fixemoustaches" - and when the mayor refused to supply these articles, they would go and phunder the store. Not content with looting what they fancied, they would wantonly destroy what they did not want or could not take away. The author one day saw them throw out into the street jewelry, cigars and glassware after helping themselves. He also saw a gang headed by an officer, force the door of a grocery shop, open cans of meat and fruit with hammers, spoil the precious and too rare food which they could not

67 Basly relates one particularly horrible crime during that period. A workingman, returning to his halfstarved family, sees a well-fed German attempting to steal a loaf-their only food for that day-from his children. He protests, and a few minutes later he is dragged away from wife and children, and shot. 


\section{PERIOD OF DOCUMENTATION}

eat, after plunging their hands into the fruit or meat eans, pulling out the contents and devouring them.

Some revolting episodes are related on pp. 70-77.

Two lieutenants introduced themselves into a large silent house, the curtains of which were drawn. Madame Sevart, who omed the property, had been buried on the previous day. The lieutenants noticing that some of the desks had been surrounded by long strips of paper and sealed, inquired of the keeper:

"What is the meaning of this?"

The man explained that it was a formality demanded by the law, pending the elaim of the property by the rightful heirs. But the officer did not allow him to complete his explanation"'and so you don't trust us!" he shonted, and drawing his sword he eut the seals, opened the drawers, tlirew the documents which they contained on the floor and trampled on them.

It was only the day before that death had passed that way (pp. 70-71).

The invaders distinguished themselves by an inconeeivable lack of any sense of honor. Under the protection of the German authorities, a quarter-master general commandeered food, 
liquor and wines,-and then went to sell them to the townspeople who dared not refuse to buy, and had to pay the exorbitant price which he demanded. During bombardments, while the people were forced to retire into their cellars, the soldiers, who were not allowed to take shelter, would improve the hour by going the round of the town to steal fowls.

That the German authorities called to their aid professional crooks, in order the better to harass the people of Lens, cannot surprise us very much after all that we have learned from other sources, but one cannot coneeive of the British, French or American armies of occupation resorting to such things. And what excuse conld be found for the following senseless act of cruelty? The deported French women were at last being allowed to return to France. Before crossing the frontier, they were examined by well dressed German women, not without education apparently, who subjected them to the indignity of making them strip. One poor woman had concealed in her clothing a photograph of her little girl, her dearest treasure. A German woman saw it, pounced upon it, examined it and inquired: "This is the photograph of 196 
your little girl?"-_"Yes, Madam"_-"Well then look," she said; and this German woman tore the photograph into small squares. She did it slowly and deliberately, as if she found satisfaction in destroying under her claws the smiling young features of that little ehild's face.

But, do what they would, the Germans did not sueceed in breaking the spirit of that admirable people, who elung together and refused to rield. Basly relates a touching example of resolution and coöperation: The flour mills upon which the town depended for its supply of bread were put ont of order, and the flour began to fail; then all the women of the town came with their tiny eoffee mills, and holding them firmly between their knees, they gromnd wheat for long hours, day after day. How beantiful, too, is his aceount of the way in which even the poorest came forward with their pennies, when the enemy demanded monstrous sums of money. How tragie the story of how, when they were locked up in their eellars for many days and nights, they bored tummels through the walls and under the streets, so that they might see their neighbors and gather eourage and comfort 
from eacl other. They saw their houses ransacked, ${ }^{68}$ and then dynamited, and the mines, these mines of Lens, the wealtl of the town and of the neighborhood, with their galleries which had been dug and built by the labor of many generations of workers, wrecked by wicked enemies who aimed not only at destroying the present, but the future also, and would have stamped out even hope. To perpetrate some of their acts of vandalism, they were driven to make use of convicts, for the soldiers, repulsive brutes though they were, would not go to the lengths that were expected of them. And finally those eitizens who had not fled, or had not been killed, were deported.

In the eighth chapter, of the second part, Injures aux femmes françaises, Basly relates one of the ugliest incidents of the occupation of Lens. It is difficult to see how Germans of future generations will be able to defend their Kultur after this: "One day an order was brought to me from the Kommandantur. I tore it up after glancing at it hurriedly. It concerned a medical examination of the women of

6810,000 workers' cottages were razed to the ground, and their gardens and fruit trees systematically destroyed. 


\section{PERIOD OF DOCLMENIATION}

Lens; it could only refer to prostitutes, I thought, and was therefore a matter of routine which did not concern me.-But it soon beeame evident that I was mistaken. The order concerned all the women of the eity!-was it possible? What were our tormentors aiming at? Were they so anxious to dishonor themselves in the eyes of the whole world? Pillage, arson, imprisonments, shootings, those were customary atroeities; we had aceepted them stoically, as fatal necessities of our position. But could we submit to the shame which threatened us? Scenes of savagery were reported from neighboring townships. Our women," said the mayor of H., "refused to respond to the summons; soldiers stopped them on the highways; paying no attention to their eries, they violently dragged their victims to a room of the town-hall where the major was waiting for them! the devils!'”

In Lens also they refused. But a few days later eertain women were commanded to appear at the Kommandantur under some pretext or other,-when they came brutal hands were laid on them, and they were loeked up with the physicians.-This did not last long. All the women henceforth refused to go, under any eircumstances, to the Kommandantur. Finally, a 
French physician assumed the task of issuing certificates, and the Germans themselves were not sorry to end the matter thus.

After the girls and women, it was the turn of the boys to be tormented. Small boys were sent to dig trenches, and they returned broken in health, mere ghosts of what they had been. In vain the parents pleaded for their release. Officers had said that they must be reduced by any means, and to show sympathy for the children was considered a crime of lèse majesté. ${ }^{69}$

$69 \mathrm{~A}$ moving description of the horrors committed in the occupied districts will be found in a little book by Benjamin Vallotton, a Swiss writer of repute, $A u$ pays de la mort (1917).

The same subject has been treated in a remarkable manner by a man who has acquired great reputation as a historian: Arthur Chuquet, member of the Institute, in his volumes De Frédéric II à Guillaume II, (Chiffons de papier, Reims et Dresde, Alsace et Belgique), and especially l'rouesses Allemandes 1914-1916 (La Guerre en Flandres, La Meuse et la Meurthe, Senlis et Gerbéviller, Les (armets des Vandales).

The behavior of the Germans in the Lens region generally, was described after the signing of the Armistice, in the Chamber of Deputies by M. Delory, representative for the eity of Lille. We quote the following passage of his speech from the Bulletin of the Paris Chamber of Commerce, January, 1919 :

"In 1916, there was the carrying off of women and children in the middle of the night by German soldiery; the streets were lined with machine-guns, women and children roused from sleep, the German soldiers remaining in their bedrooms while they dressed; and all of them, without distinction of class, were medically ex- 


\section{PERIOD OF DOCUMENTATION}

Among the books that have come out sinee the Armistice in November, 1918-and all supporting the testimony of Basly-we mention: Albert Droulers, Sous le I'oing de Fer: Guatre ans dans un Faubourg de Lille (1918). There is no passion in this volume, no dwelling on sensational crimes, but rather the author brings out the behavior of the Germans when it betrays the brutishmess of their souls. Practically the only means of persuasion they know of are blows; they find a develish pleasure in imposing moral sufferings on mothers by torturing the ehildren under their eres; they show savage fury at stubborn resistanee; - and never one example when a Cerman was moved by courage in their enemies, or yielded out of ad-

amined. Sinee this, at several different times men-1 might say children-and old mern have been carried off. compelled to work nuder the threat of hlows or of being deprived of food. It was not for the work authorized by the Comvention of Berne: hut for the erection of shelters for German soldiers. or for transportine muni tions, and at only a few kilometers from the lines. so that many of them were wounded ly fire from our own guns.

"The plain of Lens gives one the idea of a comntry that had been handed over to a builder having at his disposal formidable machines for the purpose of pulling down houses. There are no traces of any basencents or foundations left. At Douai the skeletons of buildings are still standing, but the place is like a dead eity, without inhabitants or furniture." 


\section{FRENCH LITERATURE OF THE GREAT WAR}

miration for heroism: and this is perhaps the worst of it all! Martin-Marny, Quatre ans avec les Barbares, Lille pendant l'Occupation allemande (1919); Hazard, Lille, La Ville envahie (1919); Pierre Bosc, Les Allemands à Lille (1919). . . . Then Ernest Colin, Saint-Dié sous la Botte (1919); Henriette Célarié, Quand "ils" étaient à Saint-Quentin (1919). And for details relative to the roughness with which Germans treated civilian hostages in internment camps, see the series of articles published by the same H. Célarié in the Revue des Deux-Mondes (1918-19).

$$
\text { * * * * }
$$

Several soldier prisoners' diaries have been published, or rather, should we say, those parts of the diaries which their authors were able to smuggle out of Germany, or to reconstitute from memory. One of the first to appear was that of A. Warnod, Prisonnier de Guerre, Notes et Croquis de l'Allemagne (1916). The author, a journalist and artist, was made a prisoner during the first weeks of the war. $\mathrm{He}$ has some moving incidents such as that of the little boy of thirteen against whom a ridiculous accusation of sniping was brought, because he was seen playing with a cartridge case, and who was brutally 


\section{PERIOD OF DOCEMENTATION}

carried off from his village with wounded soldiers and prisoners of war, and sent into Germany, and who for many days eried without ceasing. Other facts are of a more humorous nature, as when he sketehes the Germans who, on Sunday afternoons, eame with their families, provided with opera glasses, to view the prisoners of war behind the barbed wires of the eamp, and who laughed at the kilted Scoteh, or were horrified at the sight of the native Morocean troops, and shook their fists at the French. Warnod was in Germany for nine months; most of the time he was at Merseburg, Bavaria.

Other books of a similar kind are E. Zavie's Prisonnier en Allemagne (1917), R. de la Frégeolières, A Tire d'Ailes, Carnct d'un Aviateur et Souvenirs d'un Prisomier, with a preface by Bazin (1917), Abbé Aubry's Ma Captivité en Allemagne (1917), Albert Thierry, Carncts de guerre (1918), R. Christian-Frogé, Les Captifs (1919), Joseph Hémard, Chez les Fritz, Notes et Croquis (1919).

One of these diaries has attracted a good deal of attention and has been much praised; it is that of a young author of the name of Gaston Rion, who, a few months before the war, had published a book which was well received by the 
French reading public: Aux Écoutes de la France qui vient (1913).

Any publication, in those days of anxious expectation, which spoke of the spirit of confidence which animated the French youth, was welcomed and sure to be eagerly read. Gaston Rion was in the Ambulance service when the war broke ont and was soon afterwards made a prisoner; and, in spite of international agreements with regard to Red Cross workers, was interned in Germany. He was there nearly a year (until July 31, 1915), after which time he was allowed to return to France throngh Switzerland. He spent the eleven months of his captivity in the fortress of Orff, near Ingolstadt, in Bavaria. It was there that he wrote his Journal d'un simple Soldat; Guerre, Captivité, 19141915 (1916).

On the whole, his lot was not very hard. The prisoner's in the fortress were not well fed; they were short of news, and were often subjected to petty, even cruel, vexations, but to nothing that was really unbearable. It must be remembered, however, that this was at the beginning of the war, when the policy of the Germans was to praise France, while they rented their wrath against the English and the Belgians, in the hope 


\section{PERIOD OF DOCLAENTATION}

of bringing about a Franco-German allianee. The prisoners who returned after 1915 had a very different story to tell, and a truer aecount of the spirit of the German anthorities is found in books sueh as Les Martyrs de Lens. Riou himself knows that he was fortunate, and he repeatedly states that the prisoners interned at Orff were eomparatively well off (see pp. 105106). Moreover, they had the good fortune of being in the hands of a liumane fort commander, Baron von Stengel, who, when the hope of a reconeiliation with France had to be abandoned. was replaced by a stern, vain and exacting man. This change was made only a short time before Riou was sent back to France. What contributed very materially to Riou's comfort while in the fortress, was the fact that he was apparently well supplied with money: and, furthermore, as every one knew that he was a writer, he enjoyed a eertain prestige, and some immunity from bad treatment for fear of what he might publish.

We may be permitted to add that Riou shows from time to time that he is well aware of his importanee, and that this is apt to take away from all the enjoyment one would otherwise find in the reading of his book. Moreover, while the 
FRENCH LITERATURE OF THE GREAT WAR

facts which he relates-his descriptions of life in the fortress, of the little joys and great discouragements of the prisoners, of his reading, of fraternizing with the Russian prisoners,--are interesting and to the point, the same cannot be said of the grand introduction which, by contrast, makes the book itself look rather thin. Why, indeed, should he tell us how, during his previous travels in Germany, he had been received by Herr Banker A- "cousin of Chancellor von Bethmann," by the "great sociologist" B—, by the "famous painter" $\mathrm{C} —$, by "the most alert man he ever met" D—, by the continuator of Kant and Fichte", E_-, by the "Director" of such and such a periodical, and "leader of all the youth of Germany" $\mathrm{F}$ _- by the "grand master of German artistic life" G-, by the "future Bebel of Germany" $\mathrm{H}$ - by M. von I- "of the Prussian general staff," and "by the most influential of them all" J__ etc., ete., all of whom took young Riou into their confidence. The remainder of the book has no earthly connection with all this, -which, perhaps, is a long introduction to some other book which has not appeared, but certainly not to this plain diary of a prisoner. As for the philosophical remarks in that intro- 


\section{PERIOD OF DOCLMENTATION}

duction, they savor really a little too much of propheeies after the events. It is quite remarkable how many men in Europe have thought it interesting to tell us, - at dates posterior to August 1st, 1914-that they knew all the time what was eoming; and somehow, it is exasperating to think that they all knew all about it, and yet did nothing to avelt the eatastrophy. ${ }^{i 0}$

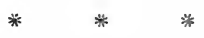

A mueh more genuine work is that of Charles Hennebois, Aux mains de l'Allemagne, Journal d'un Grand Blessé (Aô̂t 1911,_Juillet 191.j), with a preface by Ernest Daudet (1916). The author had previously published two little volumes of verse. He enlisted voluntarily at the outbreak of hostilities, was severely wounded at St. Mihiel Aug. 12, 1914, after he had been only six days at the front. IIe spent nine months in various hospitals in Germany. He is quite impartial in his appreeiation; although an ardent patriot, he readily acknowledges any kind treatment he may have received, but he also has some tales to relate whiel constitute a terrible

io Riou has also written an essay-not a little rhetorical-to commemorate the landing of the first American troops in France on July 16, 191\%. It borrows its title from the historic word of an American oflicer at La Fayette's tomb: La Fayette, nous voild̀. 


\section{FRENCH LITERATURE OF THE GREAT WAR}

indictment of Germany. There are too many such reports for one to be able to consider acts of barbarous cruelty as exceptions confirming the rule; even if we do not regard them as a matter of regular practice, the fact remains that they were perpetrated by men and women who were reared in that country, and one feels that those acts are the logical result of a revolting system of education.

Hennebois escaped death only by a miracle when lying wounded on the battlefield, because he happened to know the German tongue; it was while lying there that he witnessed the "finishing off by Germans with the butt ends of rifles and with bayonets, and the robbing of the bodies of some French wounded who had called for water."

He relates the revolting conduct of two German orderlies in the hospital where he was, who, bringing back from the operating table a Frenchman whose leg had been amputated, and was in danger of hemorrhage, "shook the stretcher roughly, raced like lunatics through the passages," - and although the patient begged them to be careful "purposely tossed the limp, mutilated body higher still, playing with it as with a living, suffering ball."' He has a terrible 


\section{PERIOD OF DOCLMENTATION}

suspieion, amounting almost to certainty, that a German surgeon, with malice prepense, but under the pretext of a new operation, made in one of his French patients a much larger and deeper wound than the first. Such pages must be read in the original, and we therefore refer the reader to the dates in ear!y December, 1914 .

But there is one page which we can reproduee. A certain Doctor W- disliked Henmebois, and this is the mean revenge which he took because he had been foiled in an attempt to harm the wounded.

"February 14, 1915.-I am in the dressing ward. I have unrolled my bandage. Doctor W- looks at me askance. The affair of a duck and of some bread is still on his mind. He is still very angry. A German, we know, takes forty-eight hours to consider a problem. My wound is almost elosed. The flesh which has shrunk very much looks healthy and red. It has ceased to suppurate.

"The doctor motions to me. I elimb upon the table. He takes his forceps, probes the wound, makes it bleed, continues ruthlessly. At intervals he turns to me: Well, patriot, does it hurt?

"I shake my" head, and the operation con- 
tinues. He strikes the projecting bone with his forceps. The pain is atrocious. I grip the sides of the table. I will not scream and I feel myself turning pale. He repeats his question, an evil gleam in his green eyes.

"Does it hurt? No? Not yet?

"I shake my head angrily.

"Yes, I know, the French are very courageous. But let us see.

"He takes the flesh in both hands, and brings the two edges together. Then he presses with all his strength. I feel a cold sweat break out over me. I close my eyes suddenly to avoid seeing the man. I am afraid of flinching, of giving way and howling aloud. The pressure continues; the scar which is broad at the edges, tears presently. The blood pours over the doctor's hand. He looks like a butcher. And he still asks: Does it hurt? I do not answer. I feel a mad desire to strike at that narrow forehead, and to cry aloud the words that are on $\mathrm{my}$ lips: Coward! Coward! Brute! But I keep silence. I raise myself with a supreme effort, and if my voice trembles, what I say at least, sounds grave and simple:

"A Frenchman can bear pain when it is neces. 210 


\section{PERIOD OF DOCLMENTATION}

sary. Was this? I think not, monsieur. But God will judge you.

"Ile laughs loud and long, sends for" a glass and pours a few drops into it.

"Drink this brandy. You have been brave.

"I refuse to drink, gently but firmly. And the dressing is completed. Doctor $\mathrm{K}$ - has arrived. He is told what has happened. It amuses him very mueh. Ife adds his contribution :

"Necessary or umneeessary, that's our business. Anyhow, the Kriegsfreiwilliger (volunteer) will remember us, and that's what we want. You may think yourself lueky to get off so eheaply. One leg is not mueh. If it had depended on me, you would have lost both."

How ean the Germans ehallenge the epithet of "barbarians" which has so often been applied to them, when such ineidents are allowed to take place in their hospitals? Their women seem to be not mueh better than their men. For one Sister Arnolda (at Offenburg), there are two others, a Sister Erigia (at San Klemens) and Frau Kommando (at Offenburg), who are regular she-devils. It is easy to understand the delirium of joy of the liberated prisoners when 
they are allowed to return to France; when they come to the border and get at last into Switzerland where such a touching welcome awaits them, not in French Switzerland only, but in German Switzerland as well. ${ }^{71}$

71 One should read also Captain Ollivier's Onze Mois de Captivité dans les Hôpitaux Allemands (Chapelot, 1916). The lively entertaining experiences of an officer, which do not differ very materially from the experiences of a private. This is another case, one of the many cases, when the life of a wounded man was spared-when he was not brutally butehered while lying helpless on the battlefield-by the fact that he knew German. He received treatment successively at Le Chatelet, Liège, Naience, and finally returned to France through Freilumrg and Constance. He relates many instances of the lack of decency of feeling in the Germans; their tactless jokes at the expense of prisoners and wounded; their readiness to adopt any new attitude ordered by the government or by eircumstances. They are impervious to any feeling of shame at the most complete volteface.

Eugène-Louis Blanchet, En Représailles (1918) must be singled ont beeanse it tells of the suffering of a particular elass of prisoners, those undergoing ill treatment under the pretext of reprisals for bad treatment of German prisoners. The volume is another terrible indictment of the Germans less because of their lack of kindly feelings (some of them were good at times), than because there seems to be nothing in them that revolts at wickedness and cruelty to a fellow-man. Some of the pages of this book, couched in absolutely moderate terms, set one's blood boiling. Scenes of pitiless clubbing and bayoneting are everyday occurrences; but when it comes to pouring boiling water on prisoners, or to tying to the post the poor helpless fellows, one feels that these tormentors belong to a race whose instincts are unknown to the rest of the world. If German prisoners have been treated one hundredth as badly, we will hear of it surely. Their whining is too well known to let us believe that 
We shall deal with one more book in closing this part of our study. It is L'Allemand, souvenirs et Réflexions d'un P'risonnier de Guerre (1919), by Jacques Rivière, Director of the Nouvelle Revue Française. This work elaims to be philosophical; i. e., not written like a diary in which the feelings of the moment are always reflected, but after the author's return to France. While he was in Germany, he had observed, and he had read. He had read with

they would bear it in silence. But we need expeet noth. ing. And, after all. why should we he surprised when we read in an Anthology of German thonght during the war (Der Deutsche Gedunlie, 1918) such passages as the following:

"Laugh aloud, O my Germany, for thy noisy enemies luave at last acknowledged in their rage that thom art the true snceessor of thy forebears! Does not thy heart swell with pride that thou eanst strike at leisure with thy sharp-edged sword? 'Marbarian? Present!' Be sineere, my Germany, thon never eouldst with gratee put up with eulture: it was too small for thee: a garment which marred thy beanty. Don the wolf-skin! it was thus arrayed, $O$ feldgrau warrior, that thine ancestor of the forests and the marshes went out to meet the foreign invader. Barbarian! and we should hfusli. forsooth, at a name so well-sounding, so aneient and so solemn! Shall we protest indeed?. . . Hail to the day when the harbarian manuer shall cover the earth; for in that day the air shall be pure as the breath of the forests, and the lives of men limpid as spring waters.

\section{(Signed) "Augustus supper."}

(Quoted from Vallotton's P'reface to I3lanchet's book.) i2 i2 The author belongs to a gromp of writers who do not consider the Revolutions of 1789 and 1848 as blessings for France. 
special care a study of the German soul by one of the most broad-minded of Germans, Professor Paul Natorp (the only professor who, so far as we know, dared to abstain from shouting with the Pan-Germanists, and even after the outbreak of the war, dared to protest against their principles). Rivière's captivity lasted for three years; and he tries to write soberly. $\mathrm{He}$ is often subtle and diffuse, but his conclusions, after three years of pondering, can be summarized in a few words. These conclusions are of much greater value than Riou's.

"I make bold to say, and to repeat without fear of being mistaken: The German is a barbarian, not perhaps in the sense in which the term is usually understood; but in so far as he has no appreciation of what is excellent. . . He is a barbarian in this also, that he does not see the stability of excellence, all that it prevents, all that it does without, the impossibility of doing better. The German is a barbarian too, by the fact that he knows no certainty, no absolute obligation. He can explore forever his own soul, he can push his investigation in every direction, in no direction does he meet with any resistance which increases as he advances; everything, to 


\section{PERIOD OF DOCUMENTATION}

him, is possible, nothing is really stable; at bottom the reason of his failure to recognize the excellent which lies outside himself, is that he has none of it within. Ife is a barbarian in this, that his intellect is in a state of perpetual migration. I am far from saying that he is not eapable of many things; I have even said that he is capable of everything. . . .' Rivière returns often to the idea of the German who does not say $I$, but ean only say": We Germans.

As for France: "It is useless to try to conceal from ourselves the fact that we are not a progressive people. .. . We must put up with it. We shall never be the first to bring about social revolutions. O my awkward France, so very far behind the point you think you have attained ... so dangerously outstripped by others. O my threatened France, but whom they have suceored, as one takes the arm of some dear tired friend, I love thee beeause nothing can make thee forget what must not be forgotten. I love thee because in spite of all, thou maintainest eontact with things that are stable. Again, I love thee beeause thou doest naught else, perhaps, than prevent or punish that mania for speed, those turns on two wheels, and 


\section{FRENCH LITERATURE OF THE GREAT WAR}

I Iove thee because thou dost not take aboard as ballast, as things to be got rid of if need be, the sacred certainties of the mind."

* $*$ *

Before leaving this subject of Prisoners in Germany, we ought to mention, though we cannot stop to analyze them, the very fascinating stories of the marvelous escapes of $\mathrm{Du}$ Tartre and Prieur, as told by D. Baud-Bovy (who had it directly from the two men), in L'Évasion, Récit de Deux Prisonniers Français Évadés du Camp d'Hammelbourg (fin 1914). ${ }^{73}$ (1917), and of Lientenant Niod as related in Mes six Évasions (1919) which has a preface by Barrès. (See also P. Ginisty et Capt. M. Gagneur, Les Belles Évasions.) ${ }^{i 4}$

$$
\text { * } \quad * \quad \text { * }
$$

We now come to books describing the effects

7a Du Tartre and Prieur also speak of the heartlessness shown by German Red Cross women. It is astonishing how frequently references to that. subject are found in prisoners' diaries.

${ }^{74} \mathrm{For}$ further documentation on Germany at the commencement of the war, the reader may eonsult Le.Journal d'une F'rancaise en Allemagne juillet à octobre 1914, by El. Altiar (1915); if the irritating je occurred less often and if the reader felt less the persistent, and very feminine desire to make "original" remarks, the book would afford much more enjoyable reading. See also Cécile Fallet. Notes d'une Internée Fransaise en Allemagne (1919). 


\section{PERIOD OF DOCUMENTATION}

of the war upon the population away from the war zone-on the Frencl side of the battle line.

It is somewhat diffieult to differentiate here, as we have done elsewhere, between novels and volumes of recollection. ${ }^{i 5}$

Marcelle Tinayre's Teille des Armes has never lost its popularity since its publication in 1915. The reason for that is the admirable blending of life with the remarkable art of that gifted woman. It is evident that she saw with her keen feminine sense of observation which never fails to penetrate deep and complex psyehie states, the thrilling first days of the war in Paris. Iler studies are like rapid einematograph seenes, very varied, taking the reader from the street to the house, from the barracks or from the factory to the station; her characters are now shopkeepers, now housewives, lovers, soldiers, officers, old men or young. None could, better than Marcelle Tinayre, amalgamate so well the two dominating features of that time: the dig-

75 As a general introduction to this subject the reader may refer to Alphand's La France pendant la Guerre, which contains a great deal of information: Mad. Mare Hélys's Les Prorinces pendant la fiuerre; a work in six volumes. 1. Bretagne; II. Bordeanx. ('ognar, le Lot d'Argent, le Béarn; III. Lyon, St. Etienne, Le Puy; IV. Dauphiné, Provence: $\checkmark$. '̇oiton. Limonsin, Languedoc; VI. Normandie, Bourgogne. Reflets de la Guerre. 


\section{FRENCH LITERATURE OF THE GREAT WAR}

nity and self-control of the people, and the genuine, deep-felt suffering. Her volume is generally regarded as a novel.

Jacques Blanche's Cahiers d'un Artiste (1916-and ff) were first published in the Revue de Paris. Four volumes of them had come out before the end of the war. The wide circle of Blanche's noted friends and acquaintances both in France and in England, his traveling both before and since 1914, added to his natural gift of telling his story simply and yet vividly and strikingly, makes this diary one of the most remarkable products of war literature, and the best general picture of France during the great war.

The first part, Prodromes, is an alarming account of a journey to the German eye-clinic of Liebenstein, in June, 1914. The moment Blanche had crossed the frontier, a feeling of uneasiness pervaded him. He was greatly surprised to see everywhere gigantic preparations for a struggle; soldiers, formidable warehouses, large railroad stations often in small villages; gnests in hotels were inconvenienced, even confined to their rooms when manœuvres were taking place in the neighborhood, ete. He also found sumptuous camfort everywhere, wealth 


\section{PERIOD OF DOCLMENTATION}

and every material opportunity of enjoying life, -although the essential condition for genuine enjoyment of life, namely "art,' was lacking. Such was Germany : rapidly making money, but embarrassed when it eame to making use of it; and squandering it to ereate an illusion... . Germany with mediocre natural intelligence, but making up for this shortcoming by the artifices of organization. . . Germany, ferociously jealous of France, where the people with much less means, and less spectacular display, betray a real sense for life. Blanche looked in vain for the simple, dreamy Germany of Renan: "They keep their people in a state of exaltation, heroic and religious"... "Germany astonishes me to the point of eompelling my admiration for her unbelievable progress and her total transformation. There were minutes during my short stay when I forgot the enemy hiding so eleverly. But, no! Impossible to feel at home here."

Then after his return, he witnessed in France the moving days of the mobilization. During the next months, he lived part of the time at his country house in Normandy, part of the time in Paris; he visited also other parts of France. Everywhere he notes the "galvanizing of the 
country by the war" ; he sees how all are anxious to do their share, eager especially to go to the front; he also witnesses how the treasures of the Louvre are put in safety ; he has visions of many soldiers in the first weeks, eoming home insane from the hell they went through. He is rather a pessimist in 1915, and expresses his belief in a long war; but much as he hates stupid optimism, he admires the continued heroism of the French people. ${ }^{i 6}$

In 1916 a small volume was published which met with a hearty reception and ran quickly into many editions. La Guerre, Madame — by Géraldy. What is this book with so strange a title? A soldicr on furlongh eomes home. War has made a new man of him, but he is curious to see what has become of Paris during his absence. He finds that the most complete misapprehensions concerning the meaning of war exist in the capital. Especially is that so among the socalled upper classes, which seem to have remained untonched, and to look upon the war rather as a somewhat annoying episode of life in otherwise normal times. Our soldier is at

i6 If one wants to see how a woman does the same kind of work one may read Baronne.J. Michaux En Marge du drame. Journal d'une Parisienne pendant la guerre. (Several series.) 


\section{PERIOD OF DOCLMENTATION}

first disconcerted, but he is too proud and too intelligent to betray his feelings; he therefore plays the part of his former self, the part of the half-snob of larisian upper eircles; and when asked by his lady-friend what war really is, he is very careful not to attempt to explain to her what she is ntterly ineapable of understanding. "La Guerre, Madame _-, the ineomplete title excellently sugrests the mentality of Géraldy's soldier. Taking it all in all, La Guerre, Madame - - is a sister book to Le Feu: but where Barbusse adopts the tragie tone, Géraldy prefers to use subtle irony. It is more elegant, just as effective, and does not prove that Geraldy suffered any less than Barbusse.

The opportmity seems favorable here to mention Gyp's war-time books. They are lalf fact and half fiction. In her inimitable Garroche style, she lashes withont merey those in the rear: "Ceux de la Nuque" as she calls them, who seem to resent the interference of the war with their petty little habits. What saves the situation in Ceur de la Yuque as well as in her other books like Les Flanchards and Le Journal d'un cochon de pessimiste, is that her stinging sarcasm has its source in righteous indignation, 
at the shameless injustice which she sees being done to the magnificent soldiers of France.

The same is true of Colette Yver's Mystères des Béatitudes, in which, however, the author adds to her censuring of the "unworthy rich," descriptions of the blessings which come to those whose modest lives are rendered terribly difficult by war conditions, but who feel the moral uplift of those who willingly sacrifice themselves to the great cause.

The same cannot be said of a sort of diary of a Parisian woman, written by her "cousin" (the author) who sees her almost daily. We refer to Marcel Boulenger's Charlotte en Guerre, Le Front de Paris (1918). It is most entertaining; we would even say-at the risk of being regarded as chagrin-it is too entertaining. La Guerre, $M a$ dame — only seems to be detached; the author really wishes us to understand that there is a deep and gloomy abyss between himself and the lady; he wants us to realize that he only pretends not to care. Boulenger, on the other hand, does not, for a moment, give one the impression that he does care. Charlotte really amuses him, and he wants to be amused. But in the midst of the awful tragedy, is so much flippancy (for it is flippancy and not healthy 


\section{PERIOD OF DOCLIENTATION}

cheerfulness), is so much flippaney beautiful? is it dignified? is it even proper to write a book about it?

It will be a relief to pass from such a book as Charlotte en Guerre, to Le Cran, by Paul Patté (1917), with its eharacters so difterent from Boulenger's, and its entirely different spirit. It is a delightful work. It is chiefly eomposed of episodes eolleeted and reeounted by a public officer during the war, Captain Paul Patté. IIe was made a kind of overseer of those who needed help, and who needed it as a direet eonseruence of the war, becanse of the loss or absenee of the breadwinner; but his duties brought him into eontact with a great number of other people. No one has had better opportunities than Captain Patté to observe how the people of France stood the test of the war; people, we mean, who, owing to their low station in life, were the most severely tried. And what he saw was truly magnifieent. He had only to write down what he had seen, as he tells us on the second title page of the book:

Vidi, audii, scripsi.

His heroes were men who, being dismissed from the army, still glowed with a desire to serve; 
women who faced the most indescribable strokes of ill luck, with a courage, an energy and a resourcefulness that fill one with reverent admiration; mere children who rise to occasions with a simplicity and a heroism that brings tears of admiration to one's eyes. One thought that the whole tale of noble deeds had been told, but one finds here things more beautiful than one had dreamed of. Nothing has revealed better than these few pages, the whole soul of the French people during the trying years that followed August 1, 1914. One laughs, one weeps, one grows enthusiastic, one wonders that so much kindness, so much dignity, so much beautiful pride, can contain within the narrow limits of human nature.

The title of the book is admirably chosen. Avoir du cran is synonymous with another colloquial expression, avoir du panache. We would say that Rostand's Cyrano has "du panache." Panache, however, is more particularly applied to soldiers. Cran may belong to the civilian as well. It is courage, initiative and enduranceand something more. Frederic Masson, the Academician, who contributes an epilogue to the book, defines cran as follows: "Avoir du cran, c'est ne pas s'épater, ne pas vouloir épater les 


\section{PERIOD OF DOCLMENTATION}

autres, et faire tout de même quelque chose d'épatant. Cela s'oppose à ce qu'ou nomme bourrer les crânes," which we may venture to translate: not to be staggered, not to want to stagger others, and yet to do staggering things; it is the contrary of what one calls blutt: ${ }^{\circ}$

* * *

We shall bring this chapter to a close with a description of IIngues Le Roux's Vort au Champ d'Ilonneur'(1917).

It is the diary of a father who had suffered eruelly already in his affections during the war. Now his son, an officer, was wounded, and he obtained permission to visit him in lospital. But it became evident that the young man must die. Wishing to give his boy a decent burial, the father succeeded, though not withont great difficulty and the exereise of much ingenuity, in getting a coffin which he was obliged to keep in his own bed room until the time when it would be required. How greatly must that father have suffered! And yet, for the sake of France he was able to bear it, for it was the beloved comntry which had demanded the life of the beloved son,

77 Two books of the same character as Le Cran are Maurice Talmayre's l'ortraits de la Belle France (1!)1!), and Marguerite Henry-Rosier's Le Chagrin sous les Vieux Toits (1919). 
and he was not insensible to the honor which such a demand bestowed. Before closing the coffin above the remains of his soldier-son, he was able to pin to his breast the decoration which had been so well earned on the field of honor and which had just been received.

There are in that book passages of the most poignant pathos. Some critics will no doubt feel that such griefs are too personal to be set down in writing and exposed to the public; that it would have been better to refer to them impersonally; to keep at least a thin veil between the private sorrow of the father and the tragedy which all the world might have known as one of the episodes of those dramatic years between 1914 and 1918. The famous sonnet by Leconte de Lisle,

Non, je ne danserai pas...

comes to one's mind as one reads the harrowing experiences of that father's soul. And yet that criticism would not be altogether fair. Those were no ordinary times, and they called for, and justified, extraordinary styles. Had the father, out of respect for tradition, written impersonally, the truth would have transpired nevertheless, and the generous critic would have pro- 


\section{PERIOD OF DOCLMENTATION}

tested: Why. eonceal the fact that that great grief is yours? The griefs of every one of us are those of all France; why ask for our sympathy thus indirectly? Tell us frankly what you have suffered, we will share your sorrow as you have shared ours!

* * * *

We have not, of course, exhausted the list. We must, however, press on rapidly, and for the following we can scarcely do more than mention the titles: Maurice Donnay's Lettres à une Dame Blanche (1917) is full of irresistible charm. The letters are addressed to a friend of the famons Academician, a nurse in a military hospital in Brittany. He gives her news of Paris, of the war, of the theater, art, etc., and relates the gossip of the eapital, much in the same manner as Madame de Sevigné pictured the eapital of Lonis XIV in her immortal letters to her daughter.

Another small volume is Tristan Bernard's Le Poil Civil, Gazette d'un immobilisé pendant la Guerre (1917). Bernard shares with Courteline the honor of being regarded as the foremost humorist of France. The title of the book is a very good indication of its general tone, but in his ironical descriptions of France at the rear of the fring line, Bernard is never very cruel. He is 
one of those men who refuse to believe in human wickedness (at least in France); he sees only human weakness, and his kindliness has redoubled since the beginning of the war.

J. Adalbert's collected articles, published in 1918 under the title Dans Paris la Grand'Ville, are lively and entertaining.

One may read also M. Arguibert, Journal d'une Famille pendant la Guerre, published by Perrin, 1916. It describes an excellent type of French family.

There are many other domains of life, too special to allow of treatment here, which have been referred to in war literature. We may just mention L'Institut et la Guerre by P. Lamy, Scerétaire Perpétuel (died 1918) of the French Academy ; L'Université et la Guerre (1919), by R. Thamin, Rector of the University of Bordeaux; and L'Instituteur et la Guerre, by Lapie. There is the expected indiscreet number of books about women, some good, some less so: Marcel Benoît, L'Energie féminine pendant la Guerre (1916), Abensour, Les Vaillantes, Héroines, Martyres et Remplaçantes (1917). Marie La Hire's La Famme Française et son Activité pendant la Guerre (1917), which describes in too many words actions which every sensible person would 


\section{PERIOD OF DOCLMENTATION}

praise if he were not told so lengthily to do so; Souvenirs de Parisicunes en temps de Guere, recucillis par $\mathrm{C}$. Clermont, which is just what one might expect from the title: La I'arisienne et la Guerre, a lecture by Maurice Dommy is excusable because it is so dainty: she is the "soldier of the science that heals, fighting against the science that destroys." War literature would, of course, never be complete without Jules Combarieu's La Jeune Fille Françase ct la Guerre, seasoned with the delicate emotion pertaining to the title; and finally, referring to all Freneh women, young and old, provineial and Parisian, rieh and poor, is Ienriette de Visme's Mistoire Authentique et Touchante des Marraines et ales Filleuls de Guerre (296 pp.). The book is much better than the sentimental title might lead one to expect. 


\section{CHAPTER III}

PERIOD OF PHILOSOPHICAL AND POLITICAL CONSIDERATIONS SUGGESTED BY THE WAR (MORE ESPECIALLY SINCE THE BEGINNING OF 1917)

\section{The Forerunners}

IT will be well to remind the reader at this stage that our division of war literature into three periods, each having its predominant character (patriotic lyricism, documentation, and philosophical considerations), was meant as a rough classification for convenience in handling, and in no way implies that the periods succeeded each other without overlapping.

There has been since 1917, a marked tendency to examine systematically and dispassionately the ethical, social, and political problems now confronting the world and, more especially, France.

But a study of the philosophical works dealing with the world crisis would be very incomplete and inadequate without an introductory brief survey of earlier efforts in that direction. Indeed, some most striking pronouncements were 


\section{PHILOSOPHICAL CONSIDERATIONS}

made not only prior to 1917 , but prior to the war itself, and often by many years. And some of the authors whose views have attracted publie attention since 1917,--because the public is now better able to appreciate them,-not only held the same views which they now do, but had already expressed them in various publications long before that date.

Let us first recall one of the earliest of those prophets: Edgar Quinet, who died in 1875. That remarkable seer, nearly a hundred years ago, i. e., in the thirties and forties of the nimeteenth eentury, had warned his eountrymen in unmistakable terms of the impending evil which came to a head in 1914. Quinet's writing had sunk into oblivion; but he has, at last, come to his own through a book in which the anthor quotes the most striking of his prophetic utterances: Paul Gaultier, Edgar Quinet, édition nouvelle de ses articles sur l'Allemagne, d'après les textes originaux (1917). Like all his eontemporaries (they were the generation of Romanticism), Quinet had allowed himself to be lured into a belief in the existence of a sentimental Germany. That belief, added to the influence of Rousseau's eighteenth century sentimentalism, formed a background for the theo- 


\section{FRENCH LITERATURE OF THE GREAT WAR}

ries of "Young France." But Quinet, anxious to see that land of his dreams, and filled with the highest expectations, went on a kind of pilgrimage to Germany. He soon discovered that the land of deep and gentle idealism was a mere fiction: a fantastic ereation of the French poets who lad conjured up on the other side of the Rhine, a Utopian dream-country, just as, in the seventeenth century, Fénclon had placed the land of his political and social Utopia on the other side of the Pyrenees. Quinet felt it to be his sacred duty to warn France of a Teutonic peril. What we now call "Pan-Germanism," he called "Teutomania." His article in the Revue des Deu.r Iondes (1842), will remain a classic. It might, if a few names were changed, be taken for the work of a thinker of to-day. So clear, so definite was his vision of the future, that an irresistible conviction forced itself upon him that the German who would be called to found and to organize Teutonism, must already be born. As early as 1832 he had proclaimed his advent: "In homme la sortir de la Prusse. . ." His friend Nichelet, who published the article in which those words oceur, was reluctant to print so positive an assertion over the name of a man who claimed to be an historian, and not a vision- 
ary, and therefore suppressed it. Nevertheless, Quinet had written it and Bismarek, though nuknown as yet to the world, was living: he was at that time studying at the University of - Göttingen.

$$
\text { * } \quad * \quad *
$$

But the ease of Quinet is so extraordinary that one may regard it as a kind of literary curiosum. At any rate, it did not prevent such strong minds as those of Taine and Renan,- to say nothing of Vietor Hugo,-from heeding, thirty years later, the siren eall of the Lorelei, the strmbolic woman of the high roek on the Rhine.

The place of honor among the forermmers of the philosophers of the Great War belongs to Mauriee Barrès. IIis warning was at least partially heeded. Ilis series of novels: Romans de l'Energie Nationale (Les Díracines 1s98, L'Appel du Soldat 1900, Leurs Figures, 1902) are intensely interesting to re-read to-day, and they fill one with admiration for the perspicacity of the author. The first volumes tell the story of that spectaeular episode in French polities known as "Boulangisme." Barrès was keen enough to see that behind "Boulangisme," as also behind the later Dreyfus aliair, there was a deep national movement: a spontaneous attempt 
on the part of the French people to unite in view of a menace which onc vaguely felt to be rising on the eastern border; for, the colonial policy of France was at that time arousing the displeasure of Germany who did not conceal her feelings. Barrès's Preface to L'Appel du Soldat has, in reference to "Boulangisme": "It was a building which was rising of its own accord and which the unfriendly spirit of a political party tore down at a time when the scaffolding still concealed from view the general outline. . . Boulangisme must be regarded as a series of efforts which the nation had made to resume its normal course after being thrown out of it by intrigues from abroad." 'In 1905, Barrès published his pathetic Au Service de l'Allemagne: the experiences of a young Lorrainer who had to undergo what to his French heart was a terrible ordeal, viz., initiation into the methods of the German army, because he would not, by a refusal to serve and by desertion to France, give to some German the opportunity of taking his place on the sacred soil of Lorraine.

The second place belongs to Charles Péguy, that quaint and fiery apostle of a "mystic" faith in the destiny of France, who, from 1900 to 


\section{PHILOSOPHICAL CONSIDERATIONS}

1914, delivered his message to the younger generation of intellectuals in his Cahiers de la Quin. zaine. After Barrès, Péguy had entreated the intelleetual élite of Franee, for the sake of Franee's salvation, to eease from their selfish enjoyment of purely asthetie ideas and other vain fancies of the imagination, and to rouse thenselves from their listless indifference to polities. When, in 1905, the King of Spain visited Paris, and an attempt was made upon his life, the incident called forth from Péguy that long artiele in the now famous Cahier: Notre Patrie. $^{1}$ On the morning of that day whieh was to have been one of rejoieing, Péguy understood more elearly than ever before how dangerous were the theories of the internationalists, and he understood at the same time the intention of Germany to foree a war upon Franee. "Like every one else," he writes in referenee to that memorable day, "I reached Paris at nine o'clock in the morning; like every one else, or at least like some eight or nine hundred other people, I realized by half past eleven that a new epoeh had begun in the history of my own life, in the

1 That article, as the title indieates, and as we have already said in Chapter I, was an answer to G. Herve's anti-militarist and anti-patriotic Leur P'atrie. Totre Patrie'has been reprinted since the beginning of the war. 
history of my country, and, indeed, in the history of the world. Every one realized at that moment that the menace of a German invasion was imminent, was upon us, was there."

A group of young men who had worked under the influence of Péguy, founded in $1909 \mathrm{La}$ Nouvelle Revue Française, a literary and political revue which bore to the purely political $A c$ tion Française (which we mention below), the same relation as the Conservateur Litteraire of Hugo, Vigny, Deschamps, etc., had borne to Chateaubriand's political Conservateur about a century earlier. ${ }^{2}$

$$
* \quad * \quad *
$$

There are two other writers who, though not such littérateurs as Barrès and Péguy, ought not to be omitted from a broad survey such as this one.

The first is Léon Daudet. He belong's to the group of the Action Française, a paper founded in 1899 by Henri Langlois, and characterized by violent anti-republican, anti-Semitic, anti-prot-

2 Péguy net with a glorious death on the field of honor, Sept. 6th, 1914 (see V. Boudon's Arec Charles Péguy de la Lorraine à la Marne Août-Sept. 1914 (1916). On the political significance of Péguy's work, consult André Suarès, Péguy (Emile-Paul, 1915). 
estant and anti-masonic sentiments, which sometimes led its editors to advocate with almost revolutionary fervor a return to what they ealled "nationalisme integral" -by which they meant the old régime of King and Church.

On September 11th, 1911, Daudet, who was at that time assoeiated with Manrras, began in the columns of the Action Française, a campaign of revelations of the German spy system, which he continued with umabated rigor and bitterness until some time after the war had begm. In Mareh, 1913, he published the substance of those articles in his L'Avant-Guerre, Etudes sur l'Espionage juif-allemand depuis l'Aflare Dreyfus. The title of the book is sufficient to explain why the public at large, and the govermment in particular, paid little attention to his warnings. The passionate denunciations of the govermment and of the Jews, which aecompany Daudet's revelations, led to the gencral belief that his spy stories were invented to ereate difficulties for the govermment. And there can be no doubt that it was his desire to embarrass the government, but his facts were nevertheless true, as every one has come to reeognize. Since the beginning of the war, Dandet has again returned 
to the subject in his Hors du Joug Allemand, Mesures d'Après-guerre (1915), the second part of which is particularly interesting. ${ }^{3}$

* * * *

The other name is that of André Chéradame, who as early as 1901 had published his $L^{\prime} E u$ rope et la Question d'Autriche au Seuil du Vingtième Siècle, which was followed, in 1903, by Le Chemin de Fer de Bagdad. But Chéradame also failed to obtain a serious hearing. Since August, 1914, however, a tragic interest attached to his warnings, and he has since been regarded as one of the most eminent writers of the day. In 1915, he summarized his earlier writings and re-issued them with a warning against the dangers of a premature peace, under the title of Le Pan-Germanisme démasqué, le redoutable Piège de la Partie-Nulle (1915). The book has been widely read as it deserved to be. Chéradame urged upon those who were anxious for a premature peace, the necessity of a clear understanding of the situation. He noted that the attention of most people was focussed on the western front, where, it would

3 See also Louis Bruneau's L'Allemagne en France, (Plon, 1913). Bruneau does not deal so much with the German spy system as with the peaceful economic penetration of France by Germany before the war. 


\section{PHILOSOPHICAL CONSIDERATIONS}

seem, the issue of the armed eonflict would have to be decided; but he reminded his readers that if the military leaders of Germany were looking westward, the eyes of her politicians had always been turned toward the East. A German Empire gradually extending from the shores of the Baltic to those of the Persian Gulf, eutting off Latin Europe from communication with Russia and overflowing into Africa, would be in a position to make any demand it chose upon the rest of the Old World, which would then be powerless to offer any kind of effective resistance. Chéradame's eharts have an eloquence of their own which carries conviction.

\section{INtellectualism versus INtuitionism}

After the first emotions which the outbreak of the war had stirred, had somewhat subsided, and when a comparative calm seemed to justify the resumption of philosophizing, the most striking feature of the writings of those who felt entitled to speak for the generation of reconstruction was an unequivocal meâ culpâ. There was no theatrical pose in it; no appeal to the gallery; no attempt to obtain an easy absolution by an easier confession. No, the sincerity, the earnestness of those men was unmistakable. They said not 


\section{merely: "We have allowed ourselves to be led astray"; they added emphatically: "It must never occur again!", 4}

4 An exeeption ought to be made here for the two volumes of Dr. G. Le Bon, La Guerre Européenne et ses Enseignements psychologiques, and Premières Conséquences de la Guerre, Transformation mentale des Peuples (1916). Certainly Le Bon has a right, if any one has, to philosophize upon the Great War, for his whole career as a writer has been devoted to the study of mobpsychology in works which have won him universal fame. (Lois psychologiques de l'Evolution des Peuples, Psychologie des toules, La lićrolution fransaise et la Psychologie des Rérolutions, etc.) But the psychological method of Le Bon is still that of Taine; he is a convinced determinist; he does not allow human will any part in the framing of history. The Kaiser, for instance, interests him very little: "Events of such formidable importance could not possibly depend on the will of a single nian." Nor does reason count for much with him: "The evolution of listory is determined by affective and mystic forces over which man's reason has no control." In this he is absolutely out of sympathy with that young France which has been bearing the brunt of the fighting. The soldiers of the Entente, at any rate, who were not led by a kind of mystic dream of world-domination, claimed that they were fighting for the reasonable purpose of freeing the world of the menace of political servitude, and they thonglt that their will must, and can, conquer the foe. The writer does not mean, of course, that Le Bon is necessarily wrong in belittling the power of reason and of will, because the modern generation does not accept his views on that subject; but for the present, such views are not in favor, and they go against the trend of the literature of the war. Perhaps we ought, in justice to Le Bon, to add that he himself is not always consistent. With his premises he ought to be content to explain matters such as the unpreparedness of France or the aggression of Germany, but should refrain from all moral judgments in the form of blame or regret. Yet he has been unable to resist en- 


\section{PHILOSOPHICAL CONSIDERATIONS}

By whom had the French allowed themselves to be led astray? Some say that it was by their politieians; and while the colonial poliey of the goverument, which was so little understood and so grudgingly supported before the war, is now praised, the eriminal shortsightedness of the Foreign Office which did not avert the war is unreservedly eondemned. Others blame the financiers who chose rather to hoard their money than to make it produetive; in other words, who were content to draw interest on their money in. stead of using it in eommercial undertakings and increasing economic wealth-like that which rendered Germany so dangerously strong. Hoarding may secm a lawful enough poliey, but it is unintelligent, selfish and unpatriotic.

But the thoughtful reader will wish to carry his inquiry still further, and to learn how it

tirely the pressure of pulblie opinion, and las proposed to comnteraet by reason and will the eflecets of the allective and mystie forces. Le Bon's books liave had a very large sale, partly on aceount of the pre-llar fane of the anthor, partly too beeause the great majority of readers move rather slowly, and Le Bon's way of approaching problems is still familiar, and therefore dear to them; and they are not to be frightened ly a little lack of eonsistency. And then, too, lee bon remains Le Bon. Every page of every volume that he writes offers stimulating reading in spite of a good deal of repetition. But stimulating reading, it must be remembered, does not necessarily lead to clear, definite and practical conclusions. 


\section{FRENCH LITERATURE OF THE GREAT WAR}

came to pass that the French government was allowed to pursue its dangerous foreign policy, and why the nation remained indifferent to the lack of enterprise on the part of financiers. The answer is that the people of France had been led astray by their philosophers and other writers. They had accepted all the more readily such doctrines because these flattered their inclinations by exalting the contemplative life and the pursuit of intellectual culture. Meanwhile, the rest of the world was striving after material gain and territorial expansion.

There are three philosophies which are severally and jointly responsible for the dangerous apathy of France.

1. The first is a sentimental Socialism based on a naïve (although, no doubt, very beautiful) belief in the brotherhood of nations: a belief which the war has proven to be, if not delusive, at least very far from realization for the present. Jaurès was the chief exponent of that doctrine.

2. That Utopian socialism, which appealed more especially to the masses, assumed among the middle classes, who claim to stand on a somewhat higher intellectual level, the form of Moralism. Moralism is based on the assumption that there exists in all men an identical moral 


\section{PHILOSOPHICAL CONSIDERATIONS}

conscience which can be depended upon because it does not, and eannot, vary from one man to another, or from one nation to another. What made matters worse, was that French philosophers, who opposed Moralism to the materialism of seientifie men, were wont to point to German philosophers, and partieularly to Kant, as the founders of their theories. In those eonditions, it was most natural that the French should take it for granted that the principles of Moralism were eommonly aceepted in Germany. They did not realize that Kant's eategorieal imperative had long since been ousted by the PanGermanist creed, and the Germans, of course, were most willing that the French should eontinue to believe that Kantian ethies were still the rule of eonduet of the nation beyond the Rhine. The best known exponent of Moralist philosophy in France is Boutroux. ${ }^{5}$

3. The third doctrine is the most baneful of them all, not so mueh because it is philosophieally unsound (which in itself may be a matter of little moment), but because it has been very

5 The fact that Boutroux has assailed German ethics since the beginning of the war, does not clear him of responsibility. One is glad to know that his eyes have at last been opened, but he has never yet repudiated his moralistic writings. 
popular and has entailed deplorable consequences. It is known as Intuitionism and has had the support of a man who has achieved in recent years a world-wide reputation as a leader among philosophers: Henri Bergson. Intuitionism does not in any way oppose sentimental socialism or moralism; on the contrary, it supplies them both with a metaphysical background. It is anti-intellectualism; it is subjectivism; a philosophy of individual fancy; in a word, it is just the kind of fluid philosophy-destructive of rational, realistic and virile thinking,- that Germany could wish France to cultivate; a philosophy of unmanly sentimentality. Nothing, surely, could be more deadly to France than the Intuitionism of Bergson; thus, Bergsonism, in the eyes of the war generation, that is the enemy ! ${ }^{6}$

6 It is only fair to say that Bergsonism is capable of another interpretation. Péguy thought so, and so did some of the young men who, like Lanux, emphasized the Pragmatic side of that philosophy. Péguy wrote: "It is a prejudice, but an absolute, ineradicable prejudice that makes us regard an intlexible reason as better than a flexible one. . . It is evident, however, that elastic, flexible methods (a flexible logic, for instance, or a flexible ethic), are more severe, for they are able to follow their object more closely. A rigid moral law will let crimes slip through its meshes that a flexible law would pursue, track down and denounce." One might answer that if Bergsomism is so very elastic, it might even 


\section{PHILOSOPHICAL CONSIDERATIONS}

Any one who is interested in the diseussion of Intuitionism should read Julien Benda's vigorous Sentiments de Critias (1917). Benda eontrasts resolutely and with fearless outspokenness, the intellectualism of Freneh thought from Descartes to modem times with that German thought which-whether sincerely or with a view to sidetrack an enemy-always leaves something to intuition. Even in its best form, i. e., in Kantian transeendentalism, German thought attempts to explain what to the human intelleet is inexplicable. It is bound therefore to end in confusion, and, in the end, has to abandon reason and resort to intuition to get out of its diffieulties-somehow. "There is no doubt that the truth is always obseure, mysterious at bottom, and no definite idea can exhaust its richness; but obscure notions, which are for the most part only confused, equirocal pseudo-ideas, are just as powerless to state it completely, and with such notions we are in constant danger of being led

offer shelter to Bernardism. If Intuitionism requires no rational principles of justice. for instance, what conceivable objection can there be to the acceptance of Might (as the Germans have done) rather than of kight (as the Allies have done), as the criterion of the Crood? One may venture to say that, had Péguy lived, he would have seen this, and with characteristic frankness and honesty, would have written a Cahier repudiating his 1914 utterances. 
FRENCH LITERATURE OF THE GREAT WAR

astray." That quotation from Parodi sums up the contention of the whole of Benda's energetic book.

Intuitionism was the gift of the German Romanticists to the world; and, had it not been for men such as Comte, Taine and Ribot, France would have been lured by it out of its normal course. It is worthy of note that all theories which are not amenable to rational thought, are German: Intuitionism, is the theory that Might is Right; Intuitionism again the theory of the superiority of the war-waging man; Intuitionism once more the theory of the right of one race to rule over others; and Intuitionism too the theory of the State opposed to the Individual. ${ }^{7}$

Benda has a particular right unmercifully. to track down Bergson. His case is certainly not that of the man who turns prophet after the event. He had, before the war, entered his protest (see his Bergsonisme ou une Philosophie de la Mobilité). Benda is thoroughgoing, for he is

i We must not allow ourselves to be misled by words. One often speaks of the "mysticism" of Péguy, but that word would convey to the mind of young Frenchmen the idea that Péguy defended with a mystic ardor ideas that were based on such strong rational arguments that there could remain no doubt concerning their truth. It is Descartes' idea that plain, rational evidence is the criterion of truth. 
not at all certain that Bergsonism can be swept away. "We may still witness," he says, "a detestation of the critical spirit, in the interests of lyricism, such as the world has never yet seen ... and we must reckon with the support that it will receive from men whose reputation is involved, I mean of that host of writers who merely vibrate (qui font de la vibration) but who never have had the shadow of an idea. The prospect is anything but cheerful for those whose only power is that of understanding." One should take note also of those significant words: "It is a serious matter that the official thinkers of the nation should be using their authority, even since the beginning of the war, to endorse errors which they know to be errors, but which they know to be pleasing to their countrymen ... and it is a still more serious matter that the vogue of such thinkers should now be dependent upon such subservience." And with even more directness: "B. and B. [Boutroux and Bergson] take good care not to pass any judgment upon such ideas." [Snch ideas as they themselves advocated, at least, up to the time of war.]

Let us therefore ehange our way of thinking, and, above all, as regards the war. "The mas- 
tery of war, like that of everything which becomes more complex, must depend less and less upon art, and more and more upon science. Art is sole mistress only in such matters as are still in their infancy.... The reason why we wish genius to be always supreme, and why we expect everything from it, is first of all because it allows us to hope for a speedy solution, ... it is also a little because it flatters our laziness, but it is especially because a certain æstheticism is to-day in favor, which 'lends religion' only to the phenomena of the instinct and of spontaneity, and considers as rather vulgar the will based on system and organization. Would it be too much to ask, in our present circumstances, for an inversion of values (renversement des valeurs)?"'-A substitution of intellectualism for intuitionism?

Benda continues his campaign. Since the war he has published a new book Belphégor, Essai sur l'Esthétique de la présente Société française. (Emile-Paul, 1919.)

* * *

A book of a similar kind is René Lote's Les Leçons de la Guerre (1917). The author of Les Origines Mystiques de la Science Allemande (1913), Du Christianisme au Germanisme 
(whieh he says was written in 1911 although published only in 1914), and again, during the war, of Germania (1916), is, if possible, even more pitiless than Benda for those who, in his opinion, have poisoned French intellectualism with faneiful metaphysicism. His work is an ardent plea for a return to clear rational thinking, such as prevailed in France in the seventeenth and eighteenth eenturies. It is a thoroughgoing attack against Romanticism, and beyond it, against the sentimentalism of Rousseau whose obseure thought places the Ego at the eenter of the universe and thus justifies all passion.

His book is dedicated to Seillière, and it eontinues the tradition established by Seillière, Lasserre and Naurras, and before them by Brunetière, Bourget and Lemaître. But in some respeets his method differs from that of his forerunners of twenty, or even of ten years before. It is not a narrow-minded attack on the scientists whose theories had been interpreted in terms of moral materialism, nor does he allow his sober argumentation to be weakened by outbursts of passion. His blows are clean, direct and hard. He traees the origin of the evil farther back than Benda or even than Edgar Quinet had done. Aceording to him, systematic attempts to depre- 
ciate French civilization and to undermine French influence began as early as the eighteenth century: Catherine of Russia was merely using flattery towards Frenchmen of the age of Rationalism when she made them believe that all Europe stood in admiration before the clever geniuses of France; and the same might be said of Frederick the Great and his so-called protection of French men of letters who were exiled on account of their advanced ideas (Voltaire, Diderot, etc.). Those bourgeois monarchs really got the best of France, and by astutely flattering Frenchmen rendered them harmless. Lote has some remarkably suggestive, if sometimes not quite convincing passages : for instance, wheu he points out the "idyllic bonhomie of the old Gessner," preparing the sentimental Germany which could be used later, to conceal for a time from the outside world the lusty beast of the invasion of Belgium; or when he exposes the "austere criticism" of Lessing which was meant to ruin the prestige which French classical literature had enjoyed in Germany; or again when he points out the Goethe who has been "worked with great skill" : first the "European" Goethe who was presented to France as a proof that 


\section{PHILOSOPHICAL CONSIDERATIONS}

there was but one Europe; then the "Olympian" Goethe representing a eivilization which was above the low, human aims of dominion and con- . quest; or again, the "Bourgeois" poet of Ilermann and Dorothea, who was so well conceived to convinee the French of the good-heartedness of Goethe, and to excite their admiration for his high intellect. In a word, Goethe play's a symbolic part in the "illusions" of the French people and has contributed more than any other to make them "heedless (itourdis) apostles of medioere Germany":- a Germany, be it said, which was the ungrateful heir of a superior eivilization: that of Louis the Fourteenth. Let France, therefore, cease from bending the knee before the "romanesque adventure of the alchemist Faust.",

Elsewhere Lote sees in that persistent study of Romance philology by German scholars a clearly unfriendly purpose; that, namely, of undermining the national sentiment, by showing in French literature and in the various French dialects the traces of entirely different races which had been accidentally united under one political rule. Here, for instance, were the Celts, there the Walloons, there again the Provençaux. 
These scholars clearly wish to suggest that in dismembering France, one would be doing the most natural thing in the world.

But what of philosophy and metaphysics? Nothing, of course, could afford more satisfaction to the leaders of Germany, than that French scholars should advocate an impassible and disinterested science, and should put all their energy to the attainment of aimless erudition. Meanwhile, German science identified its aims with those of imperialistic Pan-Germanism; German science and German inventive genius worked together to perfect the Krupp works, while the French philosophers were naïvely outdoing Kant and the old-time German philosophers in metaphysical acrobatics. While the young men of Germany were being indoctrinated into the principles of Treitschke and of Bernardi, the French youth were bursting the walls of the lecture room of the intuitionist metaphysician Bergson. . . Bergson, again, has to bear the burden of reproach.

The world-so Lote says, summing up-is now threatened with two imperialisms. First, PanGermanism which would establish its sway by might of arms, and secondly, that gentle, "evangelical" Utopian Socialism, the logical outcome 


\section{PHILOSOPHICAL CONSIDERATIONS}

of which is anarehy. Which of the two will triumph? Let us hope that neither will, but that the world will belong to science; "cruel but necessary seience of struggle and conquest" ; for, if things work out in that mamer, then the spirit that inspired the classic civilization of France (a civilization based on principles at the same time rational and humane), will come to its own. As soon as clear thinking and keenness of intellect are restored to their rightful places, France's day will have dawned anew.

* * * *

In concluding this chapter, we call attention to a movement started some years before the war, and directed against the blind admiration of the French for certain German writers, and the adoption of so-called German methods in the French Universities. The stir created in 1911 by Agathon's ('Tarde and Henri Massis) L'Esprit de la Nouvelle Sorbonne, has often been recalled of late, and denuneiations of that kind have become more violent since the beginning of the war. But, on the other hand, there are those who regard the tabooing of everything German as excessive: and they have been able to point to a great lack of unanimity among their opponents as to which of the German authors 
were particularly objectionable. Many, for instance, are agreed that Nietzsche's following in France has been ill-omened, while others maintain that Nietzsche has been misunderstood and that, moreover, he despised his own people as much as any other writer since his time.

There exists quite a literature on that subject. While Claudel, Lote and Benda exorcize Nietzsche, Goethe and Kant, to say nothing of Luther, "who is with the Devil"' (Claudel), Henri Bois, in Kant et l'Allemagne, clears Kant of the accusation of having been a forerunner of Pan-Germanism and the "inspirer of the military philosophy invoked by Germans to justify their misdeeds," and Alphonse Aulard, in La Paix Future d'après la Révolution Française et Kant, recalls Kant's plan for universal peace. Even Suarès, as was pointed out in a previous ehapter, maintains that the spirit of Kant is much less German than that of an author of the type of Joseph de Maistre. A young poet, Henri Dérieux, is strongly in favor of keeping alive our admiration of German classics (see below, Part II, ch. 1). Again J. Rivière, in $L^{\prime} A l$ lemand, reproaches Kant harshly for his contentless "categorical imperative" which the Hohenzollerns used for the profit of Pan-Germanism. 
Lasserre, in a special little book on Le Germanisme et l'Esprit II umain, condemus Kant, Schelling and Fichte, but recommends Goethe, Heine and Nietzsche. C. Bomnet in l'Ame du Soldat (Chapter III), meekly welcomes them all-he is almost Romain-Rollandist. ${ }^{8}$

\section{Neo-Catholicisir aNd "PaPAlisir"}

If we attempt to define the constructive doctrines of the French war literature, we shall find that there are two which are well characterized.

They run parallel to each other: but while tle one seems to lave yielded already the best that may be expected of it, the other, for reasons which we shall explain later, has been slower in its development. A brighter future is, however, undoubtedly in store for it, and the lateness of its development will not be without compensa-

8 For documents relating to the discussion of the value of German authors and of their moral respon. sibility in regard to the present war (Luther, Goethe, Nietzsche), ef. Vic, Littérature de la (interre, vol. I, pp. 67-i2. An account of the discussion of the case of Nietzsche alone would easily fill a volume. Writers have vied with eaeh other to obscure an issue which is quite clear: Nietzsche hated the Germans and sometimes praised the French: nevertheless the Germans, who allow nothing to go to waste which will help Pan-Germanism, have made abundant use of his Gospel of Might as opposed to the gospel of effeminate Chris. tianity preached even now by Pacifists. 
tions. The first of these doctrines may be termed "Papalism," by which we mean NeoCatholicism in so far as it represents a political rather than a theological creed; the other might be called, provisionally, "Democratism," a term which is vague, but rightly so, for it is intended to cover a multitude of shades of one general trend of thought.

Papalism is a pre-war doctrine. It was first taught (together with violent yet guarded outbursts of monarchism from which it is now almost entirely dissociated) in the hope of putting a stop to the disorders resulting from the strife of various republican parties: disorders which appeared increasingly dangerous as the menace of a war with Germany came to be more clearly realized. Twenty-five years ago, philosophers and mell-of-letters like Brunetière, Bourget, Lemaître and Coppée propounded views similar to those of Papalism which were then set forth, for the general public, in the columns of the famous periodical L'Action Française (from 1899 forward). The movement, with its chiefly political aspect, was then called "Nationalism." Both the political and the philosophical expositions of that doctrine were given later by Barrès in his 


\section{PHILOSOPHICAL CONSIDERATIONS}

two remarkable series of novels, Le Roman de l'Énergie Nationale and Les Bastions de l'Est (1898-1902); by Charles Maurras in the Rev'ue Encyclopédique Larousse (1895-1900) and in his L'Avenir de l'Intelligence (1905); by Pierre Lasserre in Le Romantisme Français (1908), and by $\mathrm{E}$. Seillière in Le Mal Romantique (1908). Papalism received also a great forward impulse from the current of opinion ereated independently by Charles Péguy, who connected the political revival of France with the mysticopatriotic inspiration of the Virgin Mary,-the patron saint of Christianity and the impersonation of the divine love as symbolized in the great French cathedrals-; and with that of Joan of Are and of Sainte Geneviève, the patron saints, respectively, of France and of the City of Paris.

The thinking public of France was therefore not unprepared for the doctrine of Papalism when, after two years of war, the discussion of social theories and of political organization was resumed. As might be expected, Charles Maurras, who was already known as one of the most forceful writers of the day, made a skillful and decisive use of the opportunity which presented itself. Two circumstances favored his pointing 
to Rome as the source of hope and of inspiration: first, the revival of interest in religious matters which the war had awakened, and secondly, the fact that the very outrages of the Germans in Belgium, and especially at Louvain, had given to a Roman prelate, Cardinal Mercier, a prominent place among war personalities. Maurras's articles have been reprinted in book form. They form several volumes from which we select $L e$ Pape, la Guerre et la Paix as typical at once of his style and of his teachings. That work, indeed, cxhibits all the vigor, incisiveness and logical consistency which are characteristic of Maurras. Unlike Brunetière, whose dialectic power is often weakened by the use of heavy and complex sentences, Maurras has the neat, clear traditional French style of Bossuet and Joseph de Maistre.

Reduced to its simplest expression, his argument is this: The world must return to the idea of a catholicity of the human race, in matters of social organization as well as in philosophical thought; there must be some sort of link between and above the national units of the world: some concrete medium of universal communion. That universal communion, that catholicity, was at one time symbolized by the person of the Pope; 


\section{PHILOSOPHICAL CONSIDERATIONS}

even to-day, the Pope remains the incarnationthe only one-of the idea of miversality. Socialistic miversality has failed; imperialistic universality, in the German sense, will fail also. "That is why we wish to place before the publie a more reasonable conception than they have held heretofore, of what the Papacy stands for, and of its funetion among the nations and above them.'

"That lofty universality which once existed," Maurras eontinues, "was greatly impaired by the Reformation. The Protestant movement has meant the substitution of the irrational, subjective, moral conscience of individuals, and henceforth of nations, for the obedience to governments which dealt with problems rationally, i. e., objectively and by means of miversal principles. That movement was bound to lead to disorder; and, indeed, the civilized wolld has never known a worse period than that of the religions wars whieh spread all over Europe as a eonsequenee of the Reformation." Maurras adopts the formula enunciated by Barrès: "110 possibility of a restoration of the Commonwealth (la chose publique) without a doetrine." In our own times, Protestant subjectivism has led to the monstrous attempt on the part of an individual 
to bring all others into subjection to his will: i. e., to Imperialism. His megalomaniac "conscience" convinces the Kaiser that he represents God on earth, and that he must rule the world according to his inspiration. It is thus that Maurras attempts to give an exposition of what he calls "the perennial antinomy of German Lutheranism and of Latin Catholicism.",

Another point of Maurras's doctrine is this:he believes, as we have just said, in the possibility of a rational organization, of a harmonious coöperation of the nations under one rule; and that rule he conceives as a moral power like that of the Pope. But he does not regard all nations as equal to each other in mental development, nor does he aclmit that they should all have an equal voice in the settlement of international affairs. Such a privilege should bear some kind of relation to the stage of intellectual development which a nation has reached. Like Plato's republic, Maurras's society of nations is hierarchic in form: "The belief in the equality of nations is the cause of the anarchy which exists among European nations. ... France is certainly a nation (patrie) but not all nations are France, nor comparable to France. There are certain obligations which all nations must ac- 


\section{PHILOSOPHICAL CONSIDERATIONS}

cept; but who believes that the man from Germany, however vehemently patriotic he may be, is endowed with the same qualities (biens) or with so many of them, as the Fronchman?" Maurras admits, of course, that the Republican government of France has not been a model of what a politieal organization should be, but he recalls the seventeenth century when Freneh diplomacy under Cardinals Richelien and Mazarin (not to mention Bossuet), gave to France a world-wide prestige in matters political, and won for her the title of "Eldest Danghter of the Church." And he makes the practical suggestion that what the French govermment should do, is to send again a delegate to the Vaticau where at present the Austrian delegate controls, unchecked, the only international political organization in existence. ${ }^{9}$ (This question of sending again an official representative of the French Government to the Vatican was diseussed in an Extraordinary Session of the Cardinals of France, in Paris, February 19, 1919.)

$9 \mathrm{~J}$. Benda, who is a pitiless critic of everything that does not seem to him elear and straightiorward, has devoted several pages of his Sentiments de Critias (pp. 91-97) to the attitude of the Pope during the present war, These pages are well worth reading in view of the repeated attempts of Maurras to justify the neutrality which the Pope has maintained in spite of the barbarities committed by the Germans. 
Maurras takes up the attack, referred to above, against all those who, consciously or unconsciously, represent the Lutheran spirit in France. He belabors the pseudo-latinists (faux latinisants) who, like Pichon, follow "wretched models of barbarian make, i. e., Germanic and Lutheran models set by Kant and Rousseau." As for Boutroux, one of the guilty ones, he at least has been honest enough to go beyond Fichte and to acknowledge that Kant is the father of nineteenth century Lutheranism. But if the evil influence of Kant is conceded, why then hesitate to impeach Rousseau also? Rousseau, who was born on the borderline between Latinity and Germanism; Rousseau, the revolutionist and the inspirer of Kant and of Germany; Rousseau, by the same principle, the author of the Revolution which has been called "French"; Rousseau, the latest incarnation of the spirit of Luther? Elsewhere, Maurras declares that the Reign of Terror was the logical outcome of the Declaration of the Rights of Man and of Rousseau Sentimentalism, just as the Imperialism of Fichte was the logical outcome of Kant's Individualism. He even goes so far as to make Protestantism responsible for the sinking of the Lusitania. "In abandoning," he says, "intellectual and moral 


\section{PHILOSOPHICAL CONSIDERATIONS}

ideals in favor of material progress, the Reformation was bound to bring about such horrors. To counteract the tendency of that fatal material progress, a better and higher education of the souls of men would have been necessary; but no such education was given, and the men of to-day are infinitely less conscions of any feeling of brotherhood than were the men of five hundred, or even of two hundred, years ago. The innocent passengers of the Lusitamia were nothing to William II and his subjects." It need scarcely be said that Maurras entertains no kindly feelings toward Bergson, whose dangerous popularity irritates him: "In these days," he writes, "one may not utter the word quality in any official gathering without bowing deeply before that Scoteh Jew who is not even a thorough student of Aristotle and of Saint Thomas." 10

* * * *

There are two other books of a similar tendency which have attraeted a good deal of attention. They are Henri Massis' Le Sacrifice (1917), - a work which was crowned by the

$10 \mathrm{~A}$ good and impartial appreciation of Maurras's work came out in 1918: Gonzague True, Charles Maurras et son temps, A. Colin (80 pages); and another, A. Maurel, Six Ecrivains de la Guerre, pp. 97-126 (1917). 


\section{FRENCH LITERATURE OF THE GREAT WAR}

Academy, and Vallery-Radot's Le Réveil de l'Esprit (1917).

Massis is the man who had written, in 1912, in collaboration with the younger Tarde, L'Esprit de la Nouvelle Sorbonne, in which the "German' methods of some Paris professors were sharply criticized. It was soon after this rather sensational work that he began to shift towards Catholic dogmatism, and finally went as far as it seems possible to go in that direction. ${ }^{11}$

There is, however, a marked contrast between Massis and Maurras. Maurras has a keen, robust mind, or, if you will, the mind of a dialectician, and it is in the name of reason that he advocates a social organization of the world under the supervision of the Pope; but Massis is a fanatic; with a generous, but really quite unseductive ardor, he denounces as the primary cause of the present world catastrophe, that very, reason which Maurras opposes so strongly to the subjective Protestant conscience. His book is alert and stimulating, but even when his elo-

11 Massis was a special friend of Ernest Psichari, the young Catholic officer killed in the first days of the war, author of L'A ppel des Armes and of La Veillée du Centurion. In commemoration of this friendship, Massis wrote in 1916 a little volume on Ernest Psichari. His hook Le Sacrifice is made of a collection of articles written since 1914. 
quence moves us, it fails to convince,-how could it, since he never ceases to use reason to prove that reason deceives, and must be replaced by dogma? He evokes Péguy and Psichari, discusses war and polities, alway's abusing "la raison dépravée des modernes" and "la vaste et charnelle futilité du temps présent." He interprets the fieree struggle of the war mystically, as the death grapple of the flesh and of the spirit; and assigns to suffering France a rôle comparable to that of Christ when he died to expiate the sins of the fallen human race. His view of the war is that it is an act of purification of the world by Catholie France: "All that is spirit will be saved in this struggle; therefore, whether we will it or not, it is the Christian world that France is fighting for.'

$$
\text { * * * }
$$

Vallery-Radot was known before the war as the author of a novel which told in burning words of a conversion to Catholieism, L'llomme de Désir (1913). Since the beginning of the war, he has published an Anthologie de la Poésie Catholique, de Villon à nos jours (1915), in the preface to which Claudel wrote: "Who would suspect, in reading Rabelais, Montaigne, Racine, Molière, Victor Hugo, that a God died for us on 
the Cross? This must cease." His Réveil de l'Esprit (1917), even more than Massis's book, may damage the cause it was meant to defend. The reader of it, who may perhaps have been convinced by the wonderful dialectic skill of Maurras, may well be shocked and tempted to part company with the Neo-Catholic movement. This exalted, not to say inflated, style, may be dazzling, but it is confusing as well. Like Massis, Radot indulges in furious attacks against rationalism, Rousseau, Protestantism and the materialism of the present age, but we have looked in vain for that clear and concrete thought of Descartes and of Bossuet which he claims to be the distinguishing mark of Neo-Catholicism. To denounce bitterly "democratic fetishism" or the "morbus democraticus" is mere verbal eloquence; or to talk loudly of the "Protestant and Revolutionary pride which has passed into our veins with the liberal virus" is no refutation; to call the other party "Cain" while reserving for oneself the designation of "Abel," has little value as an argument; and to proclaim unceasingly that one represents the élite without adducing any proof in support of one's claim, is, to say the least, dangerous. Neither does ValleryRadot show himself a chivalrous opponent by the 


\section{PHILOSOPHICAL CONSIDERATIUNS}

preposterous summary of Rousseau 's doetrine to which he treats his readers in the introduction to his book; especially in view of the fact that his fanatical diatribes against twentieth century frivolity and corruption, remind one very strikingly of Rousseau 's famous l'rosopopociu of $\mathrm{Fab}$ ricius directed against eighteenth century frivolity and corruption. When he actually condemus the sanitary and well lighted houses of our times, he makes proof, not of superiority, but of positive short-sightedness. And has he a right to elaim, as he does, that the world is already converted to his views? "All the forms of thought whieh tried to eclipse Christianity during the nineteenth century, and whieh seduced even the élite,-Pantheism, Rationalism, II umanitarianism and what not?-have fallen as rotten fruits to the ground; they are things dead, to which only individualistic fetishism and the ranity of the old world, sneceed in lending the appearance of life." Even the faet that it is from the depths of the trenches that he proclaims his triumph, cannot remove all our doubts as to the reality of his victory; and one camnot help wondering why he should, in that case, expend so mueh passionate energy in tramping on a fallen foe.

Nevertheless, any one who wishes to inquire 267 
into that current of thought would do well to take cognizance of Vallery-Radot's book. The Christian-Catholic interpretation of the war he shares with Massis. He too regards the cataclysm as sent by God. "I have understood the criminal folly of our elders. . . . I have understood the warning of the Sacred Heart. Matter [materia] progress] has turned against us and crushed us; that is the secret of this war." But "our generation has done with the Manichean suicide [i. e., the idea of the equal power of mind and matter, for matter must be subordinated to mind]; we have re-discovered the truth of the Incarnation; our generation wants the spirit to become flesh and to sanctify the flesh, as the Word whom it worships, did of old.'

Only one more example of that curious mystic style. Vallery-Radot protests against the term "poilu." "No," he eries, "the real hero is much more beautiful than that hairy animal of the false legend; it is the human race which is offering itself as a sacrifice in union with the God-Man (en union avec l'Homme-Dieu); and what we are beholding is a new Passion of Christ even though he (the soldier) is unconscious of, or denies, it. Who could fail to recognize in these men, crushed under the burden of their work, 


\section{PHILOSOPHICAL CONSIDERATIONS}

bleeding from their wounds, suffering from the cold, covered with the mud of the trenches, the tortured limbs of the dying Christ . . . ?" 12

\section{Economic Democr.tTisy}

The second constructive theory, to which we have given the name of "Democratism," although not new to students of sociology, was slower in its development, partly because its technical nature made its appeal more difficult to the general public than that of a Catholie theory, and partly, too, because circumstances-we refer to the war-were unfavorable to its exposition. "Democratism" aims at a shifting of the center of gravity of our modern conecption of the State. Discarding as obsolete the tradi-

12 We have not thought it advisable to discuss bere certain books which adrance somewhat similar views, but do so in a commonplare manner: such books, for instance, as Victor Giraud's Le Viracle Francais. Giraud is a disciple of Brunetiere. but the faet that he endeavors to be so very diplomatic in the presentation of the Neo-catholic doctrine, could almost make one doubt his sincerity; while his style may appeal to the masses. it will leave the thinker mmoved. How awkward and trite, for instance, is his discussion of the literature of to-morrow! According to him, that literature will be distinguished by a return to French traditional classicism, it will be patriotie. Will not advocate the cult of the ego, but will teach solidarity and it will have religious inspiration. In other words, the literature of to-morrow will be exactly what men of Giraud's opinion would wish it to be. 
FRENCH LITERATURE OF THE GREAT WAR

tional principles of statesmanship, and putting aside as irrelevant the question of the form of government whether monarchic, aristocratic or republican, and the various theories on which they are based-the divine right of kings, the natural rights of individuals,--it proposes a reorganization of society on a purely economic basis. In other and simpler terms, Democratism regards the State as a purely commercial and business proposition.

The eutrance of America into the war and the revolution in Russia furnished favorable opportunities for the bold setting forth of those ideas which, hitherto, had been expressed only with the greatest reserve. It is true that the Russian revolution, although democratic at the outset, led to temporary disaster; but every one was aware that old-time political intrigues were at work, and were responsible for its failure. Moreover, while Russia was apparently drifting away, America's social organization began to be examined with more sympathy and interest. It became evident that a democratic political rule was, to say the least, possible.

Even without the war, that theory of the State would ultimately have materialized in France, 
though probably more slowly. Men like Pécuy, -as a careful reading between the lines of his Cahiers will show, -would not have been opposed to it. Indeed, Peguy tumed away from what is here ealled Democratism only beeause the petty personal intrigues of demagognes who posed as socialists, repelled him. Although his language was mystieal, his aspirations were eminently practieal, and he was far from oblivious of the importance of economic considerations.

If we should attempt to trace back to its origins the eeonomic theory of the State, we would find a most remarkable exponent of it in Auguste Comte, as early as $1836 .^{13}$ Bnt we must confine our attention to works which appeared immediately before the war. One of those, at least, deserves to be briety mentioned. It is Etiemne Rey's striking little book, La Renaissance de l'Orgueil Français (Les Études Contemporaines, Grasset, 1912). Rey's argument is that the first generation of bourgeois after 1870 were afraid of another trial of strength with Germany: "It was then that the hu-

13 The most lucid pre-war exposition of the economic state known to us, is to he found in the last pages of Jack London's People of the Abyss. 


\section{FRENCH LITERATURE OF THE GREAT WAR}

manitarian and internationalist doctrines were formulated; the leading classes turned their apprehensions into theories and into principles, and their adhesion to pacifism and to socialism was only a screen to hide their cowardice.' But the younger generation felt differently; they did not repudiate the idea of war, which might be a means of regaining prestige, and of bringing about material prosperity (revival of l'orgueil guerrier). They did more: they developed a new mentality; they became ambitious of regaining for France a leading place among the modern nations; for, in the future, Frenehmen must cease to waste their time and encrgies in futile quarrels between royalists, republicans, Bonapartists and socialists; they must unite to develop a strong industrial and ceonomic organization (revival of l'orgueil ćconomique). Ferry's colonial policy had already shown that Frenchmen were not strangers to such an ideal.

The following are a few quotations from Rey: "In modern states, the soldier has had to yield precedence to the manufacturer and the business man .. . but it is only within the last fifty years that the conditions of existence have really changed for the people." The result has been 
"the 'orgucil' of figures, of big interests, of large banking aecounts." And while "there are nations which have never known any other,'unfortunately for them-"eeonomic necessities, the progress of business, the widening of the world-market, the prodigious development of industry, have imposed on all countries this new order of things." Conclusion: "The orgueil économique and the orgueil guerrier have just joined hands in a same feching of national pride, and this is surcly one of the clearest proofs of a French national revival. The problem of socialism is a very serious one; but by forcing upon the world the Marxian theory of history, socialism has proved to be the most useful instrument of the new economic and industrial ideal . . . ; without it, demoeracy would have remained that narrow bourgeois conception of the time of Lonis-Philippe: a republic of wealthy manufacturers and landowner's."

What of the Church and the Neo-Catholic movement? "The part which the Church has played in the past has not been very glorious. .. . The Chureh has failed for the last forty years to take advantage either of the periods of anti-clerieal polities, or of the periods of toler273 
auce... To-day the Church of France is a great power rumning to waste." ${ }^{14}$

In 1912, Rey and quite a number of other writers whom we are about to mention, had regarded the economic re-organization of France as bound up with the aims of the Action Française. There was, however, no necessary connection between the Neo-Catholic tendencies and the economic development of France. Indeed, the two movements might prove to be incompatible; and, in fact, little by little, all conmection between them ceased. A proof of this could be found in a very significant article, "La France et l'Amérique,' written by Ch. Maurras, in 1895 (in answer to Bourget's Outre-1/er), and republished without change in 1916 in the volume Quand les Français ne s'aimaient pas; Maurras shows a profound distrust of America's civilization of wealth: "Let us by all means" unite with Bourget in his admiration for America, but let us remain French.'”

$$
\text { * * * * }
$$

Since the beginning of the war, and more especially since 1917, a number of books have been published, which show how economic preoccupations have taken the lead in the minds of inde-

14 Would Rey still maintain this view after the war? -Probably not. 
pendent thinkers, have sprung from very different quarters, and have claimed attention. ${ }^{15}$

Let us first of all consider J. Sageret's $L a$ Guerre et le Progrès (1917). Although Sageret ends on the eeonomie note, he first diseusses abstractly the prineiples involved in the great eonfliet; he keeps aloof from all controversy as regards eoncrete problems so as to safegnard his impartiality. His work is certainly the most eonseientious attempt that has yet been made to look at things objectively; he has no sentimental biases, whether patriotic or humanitarian; but at the same time, he is strong enough not to

15 Here again we shall mention only such books as present clearly and definitely some original contribution to the literature of the war. That is why we do not deem it necessary to dwell at length on Pinl Adams La Littérature et la (iuerre $(1916,131 \mathrm{pp}$.$) , although$ it is evident that the author had a vague presentiment of the orientation of thonght toward econonic doctrines. His look is full of platitudes and repetitions. with a few brilliant passages which are quite insufficient to redeem the rest. Adam tries to gness what the literature of to-morrow will be: the era "which will dawn after this war of nations will probably be an ane of cirilisateurs." He has in mind the economic development of the colonies. He quotes books dealing with Afriea, Tonkin. ete., and it is evident that he considers that some writers have already foreseen a great future for the colonies. He quotes, by the way, a curious note found among Flaubert's papers: "The next great social novel to be written, now that titles and eastes have been abolished, should pieture the struggle, or rather the fusion, of barbarism and of civilization." 
betray the cause in which he personally believes, from any fear of being unfair to the cause in which he does not believe. (Bonnet for instance, in his L'Ame du Soldat, and Romain Rolland in Au-dessus de la Mêlée, have shown that weakness.) Some of the chapters are not easy reading; his style is very philosophical, we might even say Spinozistic; but in Chapters IV, $X$ and XIII, he is admirably clear, fearless and illuminating. He has a happy knack of dislodging, by means of a pointed little sentence, ideas which have remained in some corner of the brain by no other right than that of long, undisturbed occupancy, and which make a considerable difference in our apprehension of the truth in so far as they prevent us from viewing things at a correct angle. He discusses three topics: the meaning of war, the meaning of progress, and the relation of war to progress. The raison d'etre of the book is manifestly the examination of a thesis recently advanced by German authors, that there exists an organic relation between war and progress, and in the development of which the Darwinian theories of the struggle for life and of the survival of the fittest, are used directly or indirectly to prove not only the necessity, but the excellence 276 
of war. Sageret camnot see any conneetion whatsoever between war and the progress of the human race. He explodes, one after another, various theories which need but to be elearly formulated to betray their intrinsic absurdity; the belief, for instance, that the victor is always superior to the vanquished, which rests on the false presupposition that superiority in war is identical with superiority itself. Elsewhere, Sageret shows that, frequently, in the struggle for life, a speeies which is physically inferior to its rivals will survive on account of some peeuliarity which happens, aeeidentally, to be important; and he instances the case of the rabbit, which being more developed along eertain lines, has survived several speeies manifestly superior to it in many other ways. How often does elimate, not ability, settle the question of survival between two races, favoring the inferior one, and eliminating the better, as illustrated by the case of the European in certain tropieal countries? Even in war, the physieally stronger is not always the survivor. In the Napoleonie wars, the stronger were vietorious, but a large proportion of them were killed, while the buik of the weaker survived. The same holds true in the present war. War leads to 
an inverted selection (une selection à rebours). Moreover, there can be no racial wars in Europe, for the races co-mingle in every part of the continent; everywhere there are brachycephalic and dolichocephalic men, and many people who bear German names,-in Alsace, for instance,are decidedly French in their sentiments; thus the Great War also is fought not on racial, but on national, grounds. ... In conclusion: "War is not a scientific fact, but only an historical one ... . ; we could regard it as a scientific fact only if, like all other natural phenomena, it were invariably accompanied by certain effects. But what effect of war can be regarded as constant?-Selection?... But selection does not sclect consistently the same qualities for triumph. . . War picks out the victors at ran. dom; and the victors have as little right to be regarded as scientific effects, as the rulers in whose hands, accidentally, the destinies of nations lie. It is therefore nonsense "to talk of war as an element of progress. ... War and progress are two unrelated facts, not opposed, but simply alien, to each other."

War as an element of progress being thus disposed of, Sageret turns to the real problem that 


\section{PHILOSOPHICAL CONSIDERATIONS}

lies before modern society. "War cammot be ignored, for it always remains a possibility. That is felt to be so true, that the aims of belligerents are chiefly directed toward the seeuring of favorable eonditions, not, indeed, in view of a coming peace, but ratler in view of the next war...." War simply renders impossible a rational exploitation of the Planet.

What then is progress? Sageret adopts,with modernized arguments, - the theory that all progress implies a corresponding regress, in sociology as well as in psichology and biology. That economic progress means an adrance of civilization, he accepts as a commonplace, almost axiomatic in its simplicity and requiring no demonstration. But economic progress, like all progress, has to be paid for: it elaims a tribute; and the problem that confronts a progressive soeiety is to discover how one may reduce that tribute to a minimum. And here Sageret takes up the problem so ably dealt with by Roussean in the eighteenth century, that, namely, of the cost of economic progress in terms of moral corruption, unrest, dissatisfaction, jealousy and war. This part of the work is less original than the rest. Sageret simply applies to war, 
and more especially to the present war, the ideas developed a few years ago in Haycraft's Dar. winism and Race Progress, in Demoor, Massart, et Vandervelde's L'Evolution Régressive en Biologie et en Sociologie, and in Capitaine Constantin's Le Rôle Social de la Guerre et le Sentiment Naturel which is a reply to the German Steinmetz's War as a Means of Collective Selec. tion.

Only a very short notice can be given to each of the following books:

Probus, La Plus Grande France; la Tâche Prochaine (1917). This book (crowned by the "Académie des Sciences Morales et Politiques") was regarded as quite radical when it first appeared, but it has already been outdistanced in constructive suggestions and in outspokenness. The author's criticisms of the generally accepted views with regard to political administration are strong, and when he suggests possible reforms, he generally speaks to good purpose. His main plea is for decentralization; but one cannot but feel, when he speaks of future economic, rather than political, reforms, that he has not altogether realized either their possibility or their importance. 


\section{PHILOSOPHICAL CONSIDERATIONS}

The same may be said of Lachapelle's L'Oeuvre de Demain (1917),$^{16}$ His chapters on the Constitution of 1875; the Ethics of Political Elections; Electoral Reform; Decentralization, and the Revision of the Constitution, are worth reading. Nevertheless, the book strikes one as an attempt to put new winc into old bottles.

Edouard Herriot's ${ }^{17}$ Agir (1918) is a collection of articles by a man of action. The fact that he deals exelusively with present-day problems and concrete needs rather than with abstract considerations, has led him to regard all questions from the standpoint of economies. "It is of the utmost importance," he says, "that the sources of French industry be developed. If by a politique minière-distinguished by more intelligence than our present-day polities-the soil of France could be made to yield even a part of the wealth it contains, then no hope would be too high for our country." And Herriot supports his arguments with figures. In the period

16 Another work by Lachapelle is Tos Finances pendant la Guerre.

1i Herriot was one of those who asked for the creation of a Paris Conference on economic prohlems, to supplement the work of the Conference on Military Problems, which, on March 28th, 1917, decided upon "solidarity in military action." 
of reconstruction after the war, "one law must dominate all the detail of the plan: we must make France rich." He recommends that his countrymen study the excellent hand-book by H. Hauser, Méthodes Allemandes d'Expansion Economique. ${ }^{18}$ Then in a new work Créer, published in 1919, he continues his campaign. France must be renovated by scientific methods; for England, and especially for America, he has unbounded admiration. Political prestige follows economic prestige.

Victor Cambon's Notre Avenir is very outspoken. Cambon's book is interesting especially because it is the work of a professional politician who has come to believe that, in the future, polities will have to be based on economies. He finds in the events connected with the war a remarkable occasion to renew the warnings given by him so clearly-and so stupidly ignored -in his Allemagne au Travail (1909) and again in his Derniers Progrès de l'Allemagne (1913). As to Clémenceau's La France devant

${ }^{18}$ It is interesting to note that Herriot is one of those who have understood not only the Rousseau of Romanticism, but also the Rousseau of political theories (of the article on l'Economie Politique, of the Lettre $\grave{a}$ d'Alembert, and of the Contrat Social): "The time has come," he exclaims, "to re-study Rousseau. Long live the beautiful trades of France." 


\section{PHILOSOPHICAL, CONSIDERATIONS}

l'Allemagne (a collection of articles which for the most part appeared originally in his famous newspaper L'Ilomme Enchainé) it may be well to say a few words in order to dispel some misunderstandings: for instance, to make clear that "the Tiger" was not really an opponent to what we have called the economic interpretation of war events. Even at the time when Clémenceau was "eenseur parlementaire," as well as later when he becane the "eenseur de la guerre," he aeted on the prineiple: let us not tackle the future before we have well taken eare of the present. All his hostile attitude towards colonial policies was inspired by this thought: France must be strong first in Europe before she gives much thought to economie development in Africa and Asia. And espeeially where colonial expansion brings about quarrels with England. France must be careful not to ill dispose England whose alliance is of first importance. And he was opposed to French polities in Morocen becanse he feared this would absorb energies needed to face problems at home. To the clear sighted this is good constrnctive policy in the end. Moreover, on one point he would not rield at any price: when the honor of Franee was at stake after Casablanca, he had said "no" to 
Germany, and opposed the concession to Germany of territory in French Congo in payment for privileges in Morocco.

Clémenceau's activity as a journalist during the first part of the war was consistent with his previous record. He insisted on not sacrificing the present to some uncertain future, and opposed operations on a far away front which might weaken action on the western front. He deprecated the Gallipoli campaign. And as to the fierceness of his attacks, when France needed so much to be united, that is merely the application of Clémenceau's parliamentary method, namely: there are two ways of acting as a politician; either in being a member of the Executive, or in being in the opposition and stimulating the government to act by relentless criticism: To fight with the majority is good for lazy politicians, and there will always be enough of those who say all is well and who court the ministers. ${ }^{19}$

$$
\text { * * * * }
$$

The reader must excuse this digression about Clémenceau. We come back to our topic.

One of the most curious books of the war-

'19 See the excellent chapter on Clemenceau in A. Maurel, Six écrirains de la guerre (1917); and R. Ducray, Clémenceau (1918). 


\section{PHILOSOPHICAL CONSIDERATIONS}

curious because of the entertaining way in which the author deals with really fundamental questions-is Gaston de Pawlowski's ${ }^{20}$ Dans les Rides du Front (1917), which was written while the author was on active service. Pawlowski has not only a remarkable talent for combining sound common sense and a vivid and pleasing imagination, but his criticism is always constructive. One of his favorite topies is the question of coal and oil in France (see Chapters XXII, XXVI, XXVII). Oil, he argues, is destined to replace coal; let France, therefore, protect her oil fields in Algeria and Moroceo; what would be the use of colonizing those two countries if their oil fields were to be run with German capital for the benefit of German financicrs?

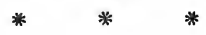

Two men have come to realize more fully than any of those whom we have previously mentioned, the revolutionary nature of their efforts to turn politics into the ehannels of economies. Their works may lack, perhaps, the conventional æsthetic adornments that one is wont to look for

$20 \mathrm{He}$ had previously written an Essai sur la Quatrième Dimension in which lie advanced some bold and interesting hypotheses, and Inventions Touvelles et Dernières Noureautés. He is a kind of French H. G. Wells, with a comic vein and an abundane of wit. 
in literary productions, but they are nevertheless beautiful. Their eloquence is that of facts and figures, which they have raised to the dignity of art.

The first is Pierre Hamp, who is connected with the Nouvclle Revue Française. He has written under the general title La Peine des Hommes several striking novels dealing with industrial problems: Le Rail (the railroad problem); Marée Fraîche (the fishing industry), Vin de Champagne (the wine industry), since the war L'Enquête and Les Métiers blessés. Hamp is the apostle of Industry which he deifies; and since the beginning of the war he has continued his preaching with unabated fervor. He has visions of labor as solving the problem of happiness in the world and especially in France. His books are well worth reading. With more conviction than even before 1914, he says in reference to the task of the future: "We are face to face with this moral necessity: France must be rich." And France must set to work at once: "War is transitory, labor is eternal.", 21

21 Pierre de Lanux, in Young France and New America (pp. $73-56$ ). has given a summary of the war books in which Hamp has developed those ideas: Le Travail Invincible, La Peine des Hommes, and La Victoire de la France sur les Franģais. 


\section{PHILOSOPHICAL CONSIDERATIONS}

The problem which France has to solve is that of substituting maelninery for men, as Ameriea has already done.

But the most vigorous books-which could eall the dead back to life-are those of Lysis: Vers la Démoeratie Nouvelle, and Pour Rénaitre (Payot). Nobody doubts that the Freneh ean aceomplish anything that they have set their hearts upon; indeed, their very cleverness and intelligence have often been a temptation to them to depend on those natural gifts for emergencies, and have lulled them into a dangerous listlessness which has more than once brought them to the brink of the abyss. In the first book, the reader will again and again come aeross plain, crude statements of this kind: "We are foreed to reeognize that that mediuval and feudal state (Etat moyen-âgenx) which we profess to hold in eontempt, knows so well how to run a government that in a few years it has reached a power astonishingly superior to ow own, and that today Germany has surpassed us in every field of industry and of agrieulture." And Lysis will brook no protest or contradiction. Ite marshals figures, terrible figures, to substantiate his statements. Shall Franee, there- 
fore, adopt German methods of government? No, indeed! and for this very simple reason, that democratic governments have achieved similar progress along the same lines; the form of government has nothing to do with the question: "We have a temperament and aspirations which are our own; the Americans are not German, neither are the English, nor the Italians, the Belgians and the Swiss." France must do what Germany has done, but not as she did it.

One falsehood which has, for many years, been blindly accepted all the world over, must be stamped out: it is that France is wealthy. "France is really a poor country," poor because it is undeveloped. To say that there is money in France, and capital, is also false. Moreover, "true wealth is not money; true wealth is the means of production," and since whatever French capital there is, is very largely invested abroad, France is contributing to the wealth of other nations at her own expense. What must be, above all, brought about after the war, is a new revolution, viz., one in French "democratic mentality." France must get rid of her political leaders, as she got rid of her "noble" leaders in the first Revolution. The nineteenth century has witnessed the taking of the power from the $28 s$ 


\section{PHILOSOPHICAL CONSIDERATIONS}

hands of the titled nobility, and its committal to politicians; now the twentieth must see that the politicians are also turned out, and their place taken by men trained in industry and commerce. $^{22}$ The fact that we have to face is that economic wars are not on the wane, but rather on the increase; and both employers and employees must unite to govern the State. The reader will easily see how very different this is from conventional socialism.

The second book, Pour Renaître, contains a similar vigorous plea for sound practieal thought on "the German progress and the French decline of the last forty years." The alcohol problem must be dealt with energetically. Aleohol for drinking purposes must go, for it has done incalculable harm to Franee (there were, at one time, cafés in the proportion of one for every four houses in Paris), bnt industrial alcohol, alcohol as motive power, must eome. To render any fraud impossible, industrial alcohol must be rendered undrinkable by the addition of ingredients which make it nauseous. ${ }^{23}$

22 Some of Lysis's remarks concerning the necessity of getting rid of politicians were censored; enough, however, of his argument was allowed to stand to permit the reader to pursue it to its logical end.

23 Since the war Lysis has published a summary of 
Literature of this kind carries us back in thought one hundred and fifty years to the days when men like Voltaire, Montesquieu, the Encyclopedists, and the Physiocrats, dealing with similar problems, brought about the first phase of the social revolution. We seem at present to be on the point of entering upon the second phase. $^{24}$

his beliefs in a short book called: Profession de foi de la Démocratie Nouvelle. (1919.)

$2+$ The reader may know that in Germany a very similar movement is on foot towards economic democratization of the state; but with some truly Germanic characteristies. The book by Walther Rathenau is very illuminating. Rathenau is the man who, when the war broke out, was called to the direction of a most important service, that dealing with the administration of raw material for war purposes (Dcutsche Kriegesrohstoffabteilung). He called his book About Things to Come (Ton Kommenden Dingen) and it was published 1918: In the State of the future everybody will have to work; no leisured class will be tolerated; society will be nothing but a huge economic organization: but there will be none the less a governing class, and this class will be the Prussian nobility. No room, in the book of the Jew Rathenau, for such nonsense as Rousseau's and the French Revolution's "peuple souverain," or as America's "Government of, for. and BY the people." The masters (Prussian nobility) must make to the masses (of the Sozial-Demokratie) all necessary economic, political and financial concessionsand these will be sweeping-but they must remain in control. This arrangement will be perfectly acceptable to the masses, especially in Germany, where they have shown their readiness to yield to the discipline imposed from above. The volume of Rathenau is full of interesting ideas. 
PART II 


$$
\text { . }
$$




\section{CHAPTER I \\ POETRY OF THE WAR}

\section{HERE we have a good harvest.}

Very few poets had thought of, or at any rate, given much attention to, war before the war. We must however recall the Chants du Soldat (1872) and the Nouveaux Chants du Soldat (1875) by Paul Déroulède, which ever since they came out, appealed to the innermost heart of Frenchmen. Then, we must recall also the moving poem by Charles Péguy, with the ever recurring words, Heureux ceux qui sont morts! It was taken by many as a prophecy of the poet's own death, and of the death of his fellow soldiers; in any case, it is a most remarkable panegyric ante-mortem of the soldiers of the Great War, and some lines from it will form a particularly fitting introduction to this chapter:

Heureux ceux qui sont morts pour la terre charnelle, Mais pourvu que ce fût dans une juste guerre.

Heureux ceux qui sont morts pour quatre coins de terre,

Heureux ceux qui sont morts d'une mort solenelle! 


\section{FRENCH LITERATURE OF THE GREAT WAR}

Heureux cenx qui sont morts dans les grandes batailles

Couchés dessus le sol à la face de Dieu.

Heureux ceux qui sont morts sur un dernier haut lieu,

Parmi tout l'appareil des grandes funérailles.

Heureux ceux qui sont morts pour leur âtre et leur feu,

Et les pauvres honneurs des maisons paternelles ...

Heureux ceux qui sont morts dans une juste guerre; Heureux les épis murs et les blés moissonnés! . . .

Heureux ceux qui sont morts car ils sont retournés Dans ce même limon dont Dieu les réveilla. Ils se sont rendormis dans cet alléluia . Qu'ils avaient désappris devant que d'être nés.

Heureux les grands vainqueurs. Paix aux hommes de guerre!

Qu'ils soient ensevelis dans un dernier silence. Que Dieu mette arec eux dans leur juste balance Un peu de ce terreau d'ordure et de poussière.

Que Dieu mette avec eux dans le juste plateau Ce qu'ils ont tant aimé quelques grammes de terre. Un peu de cette vigne un peu de ce coteau, Un peu de ce ravin sauvagé et solitaire. ... (Prière pour nous autres Charnels, dans la collection Eve) 
Poetry lent itself partieularly well to the expression of righteous anger against Germany. At the beginning of the war, a good many poets did use thus the "corde d airain" of their lyre. Some have sounded no other note even at a later date. We mention without comment J. de Marthold's Chant de Haine, Réponse à Berlin (1915), which this poet felt called upon to write in answer to Lissaner's famous Song of Hatred against England; the collection of Lecon's Germaniades: Eux, Leurs Crimes (1915); and Félieien Chamsaur's eurious, elaborate, and sometimes truly powerful L'Assassin Innombrable, Symphonie Dramatique de IIaine contre Guillaume II, Roi de Prusse, Empereur d'Allemagne, et Chant d'Amour pour nos Morts (1914-1917) composed after a visit to the Hell of Verdum.

But the following volumes, in which this note of indignation prevails also, deserve more attention. They are not-it will be notieed-written by soldiers; but they come from the pen of well known poets of to-day, who found truly deep expression for the great tragedy.

The place of honor belongs to Emile Verhaeren, the author of Les Ailes rouges de la Guere (1916). The Belgian patriot did not 295 
try to conceal his passionate hatred for the brutal conqueror of his beloved country:

\author{
0 eri, \\ Qui retentis ici \\ Si tragique aujourd'hui, \\ Tu peux courir immensément de plaine en plaine, \\ Car tu es juste, ô eri, \\ Bien que tu sois de haine.
}

Oftentimes his denunciation of Germany's wickedness and madness has recalled to the critics' minds the names of the two greatest representatives of high satire in France, the Agrippa d'Aubigné of Les Tragiques, and the Victor Hugo of Les Chatiments. The poem Guillaume $I I$ is one of the most scathing indictments of the sinister megalomaniac emperor:

Les· soirs de Fête, en des banquets,

$$
\text { Il s'évoquait }
$$

A la lueur des candélabres;

Son buste chargé d'or dans l'or étincelait, Et son verbe emphatique et farouche jonglait Ou bien avec son casque ou bien avec son sabre. . . .

Il paradait de long en large,

La fourberie animait son esprit puritain;

Il ordonnait et déplorait la tragédie

Du massacre éclairé par le rouge incendie; 296 


\section{POETRY OF THE WAR}

Pendant qu'il brulait Reims, il pleurait sur Louvain. Ses régiments?-il les dressait à eoups de bottes;

La sehlague?-il la disait âprement patriote. . . .

\section{He wanted La Gloire,}

Et dans un geste brusque il jetait son délire Comme mesure à son empire. . . .

Et ses fifres et ses tambours et ses elairons Annoneeront

Que désormais surgit sous le eiel d'Allemagne, Pour la terreur du monde, un plus grand Charlemagne.

Hélas! depuis le temps que ee rêve s'en vint

Battre son front étroit et vain,

On a pu voir déjà dans l'immense fumée,

Son aigle noir comme la nuit

N'étendre plus sur lui

Qu'une aile paurre et déplumée.

Au Peuple Allemand is written in the same vein, and is a bitter railing against the people who have allowed themselves to be duped, or misguided by their emperor.

Dans l'horreur et le meurtre, et la liaine et la rage, Allemagne, Allemagne, est-ee done ì jamais Qu'une bande de rois emploiera ton courage $A$ préparer un erime ou parfaire un forfait? 
Seras-tu à jamais hypocrite et brutale

Et morne et dure, et celle, hélas, qui n'aime point?

Tu ne livres tes bras qu'aux besognes cruelles. Ton histoire n'est qu'égoïsme âpre et profond. Pourtant une autre existe et plus grande et plus belle, Celle qui donne une âme aux peuples qui la font.

Terhaeren was in France with all the other refugees, and he remained there until his death (he was accidentally killed at the station of Rouen while trying to board a train), but his thoughts were elsewhere:

Mon âme, elle est là-bas.

Mon âme en joie et en alarmes,

Elle est là-bas

Où l'on s'élance, où l'on se bat,

Mon âme, elle est là-bas,

Dans les clameurs et dans les armes.

Elle est ardente et frissonnante;

Elle se cache et se blottit

En vos grands plis,

Drapeaux, qui promenez sur le monde la gloire.

Mon âme?-elle est déjà

Ià-bas,

Dans la clarté de la vietoire. . . . 


\section{POETRY OF THE WAR}

The volume contains various aceounts of war episodes celebrating the bravery of the Belgian soldiers and people, e.g., La F'crme du Marais d'or.

Jean Aicard, in Le Témoin, offers an enthusiastic testimonial to the part played by France in the war against Gemnany: the whole history of the world reveals a slow but sure progress towards an ideal of good-will among men; the present war will not stop that progress; it is only a bloody interlude in which France represents the Christian spirit of brotherhood, justice and sacrifice, against the spirit of the Antichrist represented by Germany attempting to rule the world by violence. ${ }^{1}$

One of the most beantiful collections of verses on the war is Zamacoïs's L'Ineffaçable (1916). His resentment against the political crimes of Germany is further exasperated by his sorrow for the victims of her atrocious methods of warfare-especially for the weak old people, for women and children. The touching little poem $L$ 'Enfant is typical of his manner; it tells the revolting story of the little boy of seven who,

1 Le Sang du Sacrifice, Poésies dédiées aux vations alliées (Textes francais, anglais, italiens) by the same poet, is of 1917 . 
at Magny, Haute Alsace, was stupidly shot by the German soldiers because he had aimed at them with his small toy rifle:

S'il est vrai, Majesté, ce crime qu'on raconte, Comme il pèsera lourd, le matin du grand compte Pour le débiteur aux abois!

Comme il pèsera lourd, lorsque dans le silence, Une main posera l'enfant sur la balance

Et son petit fusil de bois!

The graceful and kindly poet of Les Bouffons was one of those who found it very hard to realize that men actually existed who were criminal enough to allow the war to break out, and especially to allow it to be conducted with such diabolical cruelty. So, after giving his sympathy to the victims, he returns in closing to L'Homme responsable:

Done un homme pendant des nuits et des journées* Qui forment bout à bout un grand nombre d'années, A pu dans son esprit, sans devenir dément, Entendre résonner ces six mots constamment: La guerre? . . ou bien la paix?-a pu tenir captive Dans son cerveau l'horreur de cette alternative, Avec des mois de oui, des semaines de non, Sans s'écrouler un soir au fond d'un carbanon!...

(Et) la pensée alors obstinément s'arrête Sur la seconde exacte, absolue et concrète, 300 
L'instant mathématique, effrayant-inouïOù celui qui vonlut eette guerre a dit oui!

Comment résiste-t-il depuis, au eanehemar Du visiteur nocturne exsangue, au nez camard, Qui sur son lit royal- au camp sur la couchetteChaque nuit sans manquer rient s'asseoir en caehette? Comment done put-il voir sans en devenir fou, Le spectre ehaque nuit le joindre n'importe où . . .?

\section{Henri Bataille's La Divine Tragédie (1916)} is conceived on the plan of Dante's Divina Comedia. It starts with the "infernal" realities of war, in the first volume, and was to end, as the war proceeded, in a song of victory for the "divine" cause. There are some fine poems, but too much abstraet reasoning and weighing of motives, and moaning. Was the poet himself conscious of those defeets? At any rate, the work is not completed. The gem of the collec. tion is indisputably the striking piee Le Youveau Christ. Right at the summit of a hill dominating the plains of Lorraine, stood a calvary. A German shell was aimed at it, struek it, but only removed the cross, leaving the Christ standing, his arms raised in a gesture of blessing:

L'obus vient de frapper un grand Christ de Calvaire, Et le bois de la eroix s'est volatilisé. 


\section{FRENCH LITERATURE OF THE GREAT WAR}

Comme un aigle éployant les ailes sur son aire, Le Christ reste debout. Rien ne l'a renversé; Mais il est délivré du fardeau millénaire Et de son portement liturgique aux épaules. . . . And now He stands there,

$$
\text { ce Christ inopiné, }
$$

Les bras soudain ouverts et les mains déclouées, Transformant tout à coup, en haut d'un promontoire, Son geste de supplice en geste de victoire. ...

Gloire à l'obus pointé qui fondroya les Bois. Le monde est libéré, ô Jésus! Plus de croix! En mourant à nouveau dans chacun de vos fils, Vous l'arez racheté pour la seconde fois.

Other poets who could be classed with this group must be mentioned more briefly. Such are Madame Delarue Madrus, with her Souffles de Tempete (1918), ${ }^{2}$ and the Comtesse de Noailles, who early in the war sang so vigorously (in the Revue de Paris, March, 1915) the Soldats de 1914:

Nul ne mourra jamais aussi bien qu'ils sont morts ... Les mondes périront avant qu'ils ne périssent . . . Ils mettaient leurs gants blanes devant la canonnade, Et tendaient cette main de fiancé joyeux A la vierge d'airain qui leur broyait les yeux,

2 Only the second part of the volume deals with the war. In this second part, the series Deuils rouges is particularly beautiful. 
Jusqu'à ce que le jour sombrât sous leurs paupières. ... .

These last lines are an allusion to the famous oath of the young officers of Saint-Cyr to go to battle with their white gloves and wearing their plumes on their shakos. (This episode is told in Maurice Barrès's Les Traits éternels de la France.)

Gabriel Mourey's Le Chant du Renouveau (1916) shows in the soldier of the Great War the same virtues of chivalry and heroism found in the past in the epic pages of French history :

Les mots seuls ehangés, mais le rythme est le même, Et le ton et l'accent et les roix sont les mêmes.

The French soldiers are defending a just cause, drinking "le vin de flamme de la haine"; and the whole world feels with them:

\section{Faut-il, ô Franee,}

Qu'il soit irrésistible le désir,

Dont ta beauté brûle l'amour et les sens

De ces hommes, qu'ils éprouvent autant de joie

A se battre, à souffrir et à mourir pour toi !

Then again, there is Maurice Pottecher, most of whose Chants dans la Tourmente (1916) are poems describing with philosophical comments 
the succession of events from the assassination of Jaurès to the descent into the trenches, passing through the great days of the Marne. In Georges Trouillot's Gavroche et Flambeau, the idea of evoking in a poetical dialogue, the heroic Gavroche of Victor Hugo's Misérables, and the old "grognard de l'Empire" of Rostand's l'Aiglon, was better than the execution.

Soon after Edmond Rostand's unexpected death, in the first month of 1919 there was published Le Vol de la Marseillaise containing a collection of war verses by the author of Cyrano, of L'Aiglon and of Chantecler. The poems were first published in various periodicals (as $L a$ Revue des Deux Mondes, or L'Illustration) and had been inspired either by some great events of the fateful years, or by episodes that happened to reach the ear of the poet. It must be frankly owned that the quality is not even all through the volume. Some poems however are indeed worthy of Rostand, such as Caïn, Le Crime de Potsdam, L'Ile des Chiens, or the Condoléances (aux Boches). Some of those which call for a more delicate treatment are among the best, as La Vitre, Le. Nom sur la Maison, La Mère. One of the finest, perhaps the best, and of the most "Rostandesque" in 304 
beauty is ealled Les Ruches Brûlées. "They" burn the hives, beeause "c'est la guerre" answers the officer, "la brute allemande," to the priest who asks: "Pourquoi me brûlez-vous mes abeilles?" And the poet reflects: it is worthy of them, and it is better that it should be so; they betray at once their barbarian souls:

J'aime que tout de suite ils aient brûlé des ruches.

Then the bees will go elsewhere, and:

Abeille, or bourdonnant qui dans l'azur trébuehes, Ils ne sont pas vainqueurs si tu flottes encore, Dernier petit restige ailé de l'âge d'or!

The poem ends with this striking seene:

Aux premiers jours du eloe tragique, Lorsque nos eavaliers montaient vers la Belgique, On raeonte qu'un soir les cuirassiers francais Traversaient un hameau de Flandres, je ne sais Plus lequel; et sur leurs chevanx converts de roses, Tous ils ehantaient, entre leurs dents, ì bouehes eloses,

La Marseillaise. Ils la bourdonnaient seulement; Et e'était magnifique. Et ce bourdonnement De eolère latine au-dessus des corolles, C'était l'âme grondant sans geste et sans paroles, C'était la eonscience, et c'était la raison; Cela faisait un bruit d'orage et d'oraison, Pieux et menaçant, doré quoique faronehe, 305 
Calme. On ne voyait pas remuer une bouche, Et ce bourdonnement semblait sortir des fleurs.

Et ceux qui l'entendaient croyaient, les yeux en pleurs, Entendre dans le soir aux poussières vermeilles, Comme une Marseillaise étrange aux abeilles ... Et c'est ainsi que, purs, ayant fait à dessein De leur hymne de guerre un murmure d'essaim, Nos hommes s'en allaient vers le Nord plein d'embûches

Sauver le miel du monde et mourir pour les ruches.

The shattered cathedral of Rheims, and the remains of the priceless statues mutilated by German shells, inspired him this sonnet:

\section{LA CATHÉDRALE}

Ils n'ont fait que la rendre un peu plus inmortelle, L'oenvre ne périt pas que mutile un gredin, Demande à Phidias et demande à Rodin Si devant ces morceanx, on ne dit plus "C'est elle!"

La Forteresse meurt quand on la démantèle, Mais le Temple brisé vit plus noble, et soudain Les yeux, se sourenant du toit avec dédain Préfèrent voir le ciel dans la pierre en dentelle.

Rendons grâce, attendu qu'il nous manquait encore D'aroir ce qu'ont les Grees sur la Colline d'or, Le Symbole du Beau consacré par l'insulte! 306 
Rendons grâce aux pointeurs du stupide canon, Puisque de leur adresse allemande, il résulte Une Honte pour eux, pour nous un Parthénon!

We now come to a group of four poets who belong to the generation which immediately preceded that of the war. They are considered by the "jeunes" of to-day, as elder brothers. They use, to a greater or less extent, that new rhythm adopted by the suceessors of the Parnassians, which sounds very free-but is extremely difficult to handle with suecess because it discards the rules which preserved the very perceptible, although often artificial, regularity of classical French poetry.... As Verlaine said :

De la musique arant toute chose,

Et pour cela préfère l'Inpair

Plus yague et plus soluble dans l'air,

Sans rien en lui qui pèse ou pose.

The first, Fernand Gregh, has, more than any of the four, returned to the traditional form of versification. Some of his poems eome very near to classic or Parnassian perfection. The volume La Couronne douloureuse (1917) is divided into "Ire, IIme, and IIIme, année de guerre," and includes also a few introduetory poems. The 
battle of Verdun made him understand all that was really involved in that gigantic struggle, and the book opens with a poem called Vertige, written during those anxious hours:

L'univers hésitant entre la force et l'âme Va retomber de l'un ou de l'autre côté, Comme un glaive oscillant sur le fil de la lame! Heures, instants de qui dépend l'éternité. . . .

Il est grand, il est bean d'être le coeur du monde.

In "Juin 18ro," he explains the folly of the Second Empire which ended in the eatastrophe of the Franco-Prussian war, and that poem is followed by another "1910," in which the poet asks whether after forty years of suffering, France has not sufficiently atoned for the sins of the Empire.

Arons-nous fait assez, pour changer le destin?

What affects him most in the war is the stupid desolation of peaceful provincial France, that quiet, meditative France, which holds in reserve and nurses profound intellects, such as Racine, Pasteur, Péguy, who later go to Paris to feed the brain of the world. Constantly he goes back to dreams about the "Vieilles maisons," the "arbres paisibles de la route," the 308 


\section{POETRY OF THE TIR}

"pensives cathedrales," the "doux carillons."

.. His poem on Senlis is exquisite:

Est-ee toi que j'ai ru, Senlis,

Beau lien qui levais, dans les lys,

Le plus doux visage de France,

Est-ee toi que j'ai ru meurtri,

Penehant dans l'ombre un front flétri,

Eneore tout crispé de souffrance?

$\mathrm{Tu}$ dormais en ton doux vallon ...

$\mathrm{Tu}$ dormais en tes maisons ...

Tu rêvais parmi tes jardins ...

Et soudain le peuple bandit,

Dans un tragique après-midi,

Douairière, a foreé ta ehambre! ...

Tu vis, ivres de leurs exeès,

Défiler des casques à pointes!

Cette grâce dans la beauté, Cet air d'exquise humanité Que même tes maisons respirent. ...

Cette finesse des détails,

Ces ruelles, ees puits, ees mails,

Ces vieux murs moussus qui verdissent,

C'était la fleur des siècles! Mais 
C'est cela même qu'à jamais

De toute leur force ils haïssent,

Eux, les barbares tard venus

Qui rôdaient encor demi-nus

Dans les sombres forêts germaines,

Quand on lisait Platon ehez toi. ...

Pleure Senlis, sous ton coteau,

Comme le front dans un manteau. . . .

He has an admirable way of making one feel, through the mere sounds of his words, the perturbation of life by war. Read how the "sourds tambours" drum their lugubrious refrain in the poem Mobilisation:

Ces tambours, ces sourds tambours,

Je les entendrai toujours!

Ils battaient la générale

Entre les vienx murs de By. . . .

Au ciel des nuages gris,

Passaient, roulant vers Paris

Gros d'une lourde tempête. ...

Partout sur le territoire,

-Ces tambours, ces sourds tambours,

Je les entendrai toujours-

Leur rythme net et péremptoire

Préeis, rageur, obstiné,

Partout avait résomné. . . . 


\section{POETRY OF THE WAR}

Dans ces voix aecélérées,

Dans ces roulements méchants,

On sentait les dents serrées

De ceux qui quittaient les cliamps

Sans plurases, sans eris, sans chants,

Mais leurs âmes délivrées.

Ces tambours, ces sourds tambours,

Je les entendrai toujours-

Et les femmes, alu lointain,

Dans un serrement de main,

Pleuraient, pleuraient en silence.

Ces tambours, ees sourds tambours, Je les entendrai toujours! . . .

Dans un serrement de main,

L'humble escouade gronpée, $\mathrm{Au}$ détour du vieux chemin

S'enfoncait dans l'Épopée.

Ces tambours, ees sourds tambours, Je les entendrai toujours!

Then, when the irreparable has been eommitted, the ruins aeeumulated, hear the long wails of the Sanglots de Pierres. ${ }^{3}$

Henri Ghéon (physician of the 29th Artillery) has received due praise for his two volumes Foi

3 The reader should not fail to read the poem on the Victory of the Marne. 
en la France, Pò̀mes du Temps de Guerre, Per Patriam ad Dominum (1916). But, if men of letters may appreciate him, the public at large will follow him with some difficulty. He certainly tries to think before yielding to the furor poeticus. His Eloge d'un Kaiser is characteristic of his style.

Cet homme est grand et je ne crois pas juste

De l'abandonner tout entier aux satiristes des journaux. ...

\section{But}

Dieu l'a marqué sur la montagne

Pour n'être plus un homme entre les hommes

Le jour qu'il a perdu la douleur, puis le sens. . . .

The Kaiser disliked his peace-loving father, Frederick III, and despised the strong hand of Bismarck; and so :

\section{il s'est allé jucher au faîte,}

Il vit arec Dieu de plain-pied. . . .

Il crée une camelotte, une flotte, une armée, L'Ichtyosaure de Kiel et le Dragon d'Essen, La Pieuvre des mille casernes aux cent mille bouches féroces,

La Baleine volante du comte Zeppelin, Et le soldat de Vaucanson sous l'officier Pithicanthrope. 


\section{POETRY OF THE WAR}

Ah! qu'il se grise de mots et de batailles, mais ...

Vous n'êtes qu'un homme, après tout, mauvais homme!

Ghéon's First Series ends with Notre poème, another "Discours lyrique"; speaking of France he says :

Le destin du monde est notre destin. . . .

Mais il n'est pas elos ton poème,

Et tu t'es trop ouvert au monde pour te refermer maintenant. ...

Ô eoeur français, purgé des petites pensées, La plus grande sur toi descend. ${ }^{4}$

Even more than Ghéon, Paul Fort-who has had for some years now the official title of "Le Prince des Poètes" - uses with excellent effect, sometimes, the peculiar Walt Whitman rhythm. The author of Les Ballades Françaises offered his contribution to war literature ehiefly in two volumes, Poèmes de France, Bulletin lyrique de la. guerre (1914-15), and Que i'ai de Plaisir d'être Français. He dedicates his "Poèmes," of course, to Franee:

O Consolant génie de France, dont le voile,

4 Some of Ghéon's poems are translated into English in Lanux's Young France and New A merica (Macmillan, 1917) pp. 130-133. 
Par transparence, au mois élu des jeunes pousses, Et quand lèvent tant de semences,

Prend la couleur de l'espérance.-Et dans

L'aube ressuscitée, j'ouvre une âme ressuscitée à la France ressuscitée.

To speak frankly, Paul Fort, who did such original writing some years ago, has not been well inspired by the war. Here is the last part of his answer in rhythmical prose to the mani. festo of the 93 German intellectuals:

Les intellectuels Germains, tous Lèche-Bottes, ceux de Berlin d'abord ayant hurlé: "Non! Non!" d'un Gueulement de Basse agitant sa Culotte, mirent en gros Tas la Pluie d'Aérolithes, et l'un d'eux inventant soudain la Divinite, Poudre à te foutre en Poudre, ô Civilisation, envoyèrent le tout, Nom de . . . bon Dieu sans Nom! aux Armées pour nourir la Gueule des Canons."

But, for instance, his Ode to the Marseillaise is more readable:

Chant qui ne laisse plus le temps de réfléchir. . . Allons, enfants de la patrie-vaincre ou mourir.

Il fait honte aux blessés, il leur rend la vigueur, Et les voilà debout, recombattant plus fort!

Même il propage au sang une telle fureur Qu'il n'est pas que les morts qui ne se dressent encore 314 


\section{POETRY OF THE WAR}

Pour se donner encor le suprême plaisir De retuer l'infâme avant que de mourir À jamais! hymne qui revigore!

Hymne qui ressuseite! hymne entendu des morts!

Hymne qui, d'un seul eoup, dès ses premiers accents, Explose, affranehit l'air du vide: Marseillaise! Qui devient l'air lui-même oǹ passe lourazan Des âmes entraînant les corps dans la fournaise,

Capable d'entrainer, en les purifiant, Jusques aux Cieux l'immensité des incroyants Et que, pour en doter l'église triomphante, Le Christ même eut payé d'une agonie plus lente. . . .

The fourth of the group is Paul Claudel, who shared with Péguy the honor of having had the most original influence on the coming Freneh youth of France, orienting them towards national traditionalism-Claudel following, however, more elosely than Péguy the orthodox Catholie tradition. Since the glorious death of Péguy at the Battle of the Marne, Claudel holds the field alone. He has written eomparatively little referring to the war, but the Trois Poèmes de Guerre (1915) and the Vouvcaus Poimes de Guerre (1916) are worthy of him. There is a reminiseence of P'éguy"s "Heureux eenx qui sont morts!" . . . in Aux Morts des Armées de la République (Mars 1915) : 


\section{FRENCH LITERATURE OF THE GREAT WAR}

Héros qui avez été versés en masse dans la terre comme le blé,

Est-ce vrai que vous ne verrez pas la victoire? est-ce vrai que vous ne verrez pas l'été?

$\mathrm{O}$ nos frères entremêlés avec nous, ô morts, est-ce vrai que vous êtes morts tout entiers?

Debout frères entremêlés, et voyez l'espace libre devant nous, et nos armées

Qui marchent par énormes bataillons dans le soleil et dans la giboulée!

La frontière que le parjure a ouverte, forcez-la de vos rangs accumulés!

Entrez, armes de la Justice et de la Joie, dans la terre qui vous a été donnée!

$\mathrm{Ah}$, ma soif ne sera désaltérée et le pain ne sera bon,

Armées des vivants et des morts, jusqu' à ce que nous ayons bu ensemble dans le Rhin profond.

There are beautiful lines also in Tant que vous voudrez, mon général!

.. . Tous frères comme des enfants tout nus, tous pareils comme des pommes,

C'est dans le eivil qu'on était différents, dans le rang, il n'y a plus que des hommes!

Tant qu'il y aura ceux d'en face pour tenir ce qui est à nous sous la semelle de leurs bottes. . . .

Tant qu'il y aura un Français avec un éclat de . rire pour eroire dans les choses éternelles. . . . 
Tant que pour arrêter un homme rivant, il n'y aura que le feu et que le fer,

Tant qu'il y aura de la viande vivante de Français pour mareher à travers vos sacrés fils de fer,

Tant qu'il y aura un enfant de femme pour marcher à travers votre seience et rotre chimie. . . .

Tant que vous voudrez, jusqu' ì la gauche! tant qu'il y en aura un seul! Tant qu'il y en aura un de vivant, les vivants et les morts tous à la fois!

Tant que vous voudrez mon général! ô France, tant que tu roudras!

Among the poems more directly inspired by aetual fighting, if not also written by actors in the struggle, the following have met with espeeial favor: L'Arrct de la Marne, à la mémoire de Charles Péguy, 63 pages, first published in the Figaro, then separately. (Mour. Revue Française 1916.) The poet, François Porché, belongs to the group of the Youvelle Rerue Francaise, and later wrote the play Les Butors et la Finette. His panegyrie of the heroes of the Marne is divided into three parts, L'Agression, Paris, La Bataille; it is written in lines intentionally abrupt at times, yet very well hit off with original "finds," especially in the first part : 
C'est là, dans l'Oeuvre des sept jours Que nos vieilles capotes bleues Sur un front de quatre-vingt lieues Ont brisé l'orgueil des Pandours. . . .

C'est là, dans cette mêlée ivre Que fut sauvé l'honneur de vivre! ...

Et si nous vivons sans remords C'est parceque d'autres sont morts. ${ }^{5}$

Here, perhaps, belong Paul Géraldy (the author of Toi et Moi, and of La guerre, Madame -) with Le Grand-père, Joffre, (Poème dit par M. de Féraudy, à la Comédie Française, le 22 mai, 1915, 12 pages); Lucien Broyé with his stirring poem-often recited in public gatherings-on the return of the victorious "poilus" to Paris; and Paul Rougier, A la France (Prix de poésie 1917, in a contest organized by the French Academy-15 pages). In that poem, France is shown extending her hospitality to the refugees and persecuted of all nations; in other words, the theme is that France is every man's seconde patrie and a patrie for such as can claim none; it is an honest attempt to be vigorous while remaining "académique."

5 In the Revue des Deux Mondes, for Feb. 15th, 1919, there appeared another poem by Porché, Le Poème de la Délivrance, which is not so strong as l'Arrêt de la Marne. 
The inspiration of the war poets has frequently been religious and some of their works are truly beautiful. The best known collection of such religious war poems is louis Mereier's Prières de la Tranchíe. Mereier had published rather early in the war, Poimes de lu Tranchée, the first edition of which was promptly exhausted he then issued a special edition of some of these poems under the title just given, Prières de la Tranchée (30 payes). They are prayers of remarkable simplicity and directness, in behalf of all, but especially of the most humble who also help to win the war: for the sentries :

Dieu tout puissant, soyez en aide anx sentinelles! Du funeste sommeil défendez leurs prunelles;

Que la nuit passe vite, et laisse onir, enfin, Le elrant de l'alouette au retour du matin.

For the eooks (euistots):

Marthe, soeur de Marie, ô sainte ménagère, Qui vouliez réjouir Jésus d'un bon repas, Pour les humbles cuistots anréez ma prière, Et daignez être leur patronne: ils n'en ont pas.

Débraillés, marmiteux, et de rude langage, Ils jurent trop souvent le saint nom du bon Dieu, Sans savoir ce qu'ils font, et parce que l'ouvrage Est dur, et que le bois manque souvent an feu. 


\section{FRENCH LITERATURE OF THE GREAT WAR}

Devant la flamme rouge on voit leur forme noire S'évertuer le jour, et maintes fois la nuit; Ils font penser à ceux qui sont en Purgatoire, Tant leurs yeux sont brulés dans leur visage cuit.

For those who carry logs to repair the roads; for the safety of the "cagna" (the uncomfortable dug-outs where the soldiers try to rest, protected against shells while not on duty); for the peasant soldier; for the "Absente" (wife or mother) :

Seigneur, mon Dien, veillez sur l'absente qui m'aime De tout le grand amour dont je l'aime moi-même.

Donnez à ses matins un rayon de clarté Pour que son pauvre coeur en soit réconforté... .

Qu'en se mettant à table elle ne pleure point En songeant qu'elle est seule et que je suis bien loin. ...

Mais surtout, ô mon Dieu, que les soirs, les longs soirs Ne l'environnent pas de pressentiments noirs!

Que celle dont elle a le charme, que la lampe D'une lueur de paix illumine sa tempe...

Seigneur, mon Dieu, veillez sur l'absente qui m'aime De tout le grand amour dont je l'aime moi-même!

There are morning prayers and evening prayers; . prayers to the patron-saints asking for their in- 


\section{POETRY OF THE WAR}

tercession; and a supplication to the "Divine Guest" to visit and eomfort the soldiers in hours of infinite sadness:

Vous, l'ami des pêeleurs, qui sourent vous assîtes Dans leurs barques fleurant la saumure et la poix, Vers la tranehée obscure où nous avons nos gîtes Qu'il vous plaise, Seigneur, de venir une fois.

N'y venez pas un jour qu'on a l'âme um pelı elaire A cause du soleil qui luit dans le cicl bleu; Mais plutôt par un soir où l'on se désespère Parce que l'air est plein de corbeaux, et, qu'il pleut. . . .

Entrez dans un abri sans vous faire connaître, Et demeurez un peu parmi ces paurres gens. . . .

Vous vous retirerez sans vous faire comnaitre, Mais en laissant leurs coeurs moins obseurs et moins sourds,

Et puis permettez-moi ce voeu très humble, ô MaîtreFaites cesser la pluie au moins pour quelques jours!

Un Chant de Consolation, by J. Bellonard, caporal braneardier an 314me Infantarie (1916) is animated by the same spirit. The author is a priest. Maurice Barrès wrote an enthusiastic Preface for him. The reader will find in these pages a veritable Prayer-Book in verse for the Catholic soldier, with hymns, model prayers, in- 
vocations for all occasions-but the reverence for God is intimately associated with reverence for the mother-country.

\author{
Français, \\ Voyez là-bas
}

Nos frères soldats

Brisés de souffrance,

Voyez-les, vibrants d'espérance,

C'est pour l'Eglise et pour la France.

The memory of Joan of Arc, who also suffered for her faith and for France, is quite naturally evoked: the Maid of Orleans is asked to intercede for France:

\author{
C'est la France \\ En souffrance, \\ Qui te dit: Jeanne, viens à nous! \\ O guerrière, \\ Sa prière
}

Pleure humblement à tes genoux.

Sorrow and compassion, prayer and hope-such are the ever recurring themes. The warriors do not forget, in their daily intercourse with God and the Saints, the people at home who have their full share of anxieties:

Ayez pitié de ceux que nous avons laissés Seuls avec le fardeau de leurs coeurs angoissés. 322 


\section{POETRY OF THE WAR}

Ayez pitié de cellx qui sont restés lì-bas, Attendant des absents qui ne reviendront pas. ${ }^{6}$ * * *

The Protestant ereed in war poetry is repre. sented by Jean Fontaine-Vive. His little volume (108 pages) is called Jeunesse Ardente, Vers de Guerre (written in 1916, but published in 1918 only). A Preface, by G. Rion, tells that the poet was a very younc officer who earned his commission during the war, received the War eross-then the Wooden eross: he sleeps his last sleep in a little cemetery in Champagne. The title Jeunesse ardente is very fitting; the poems are full of life and fire, and permeated with a real, but disereet Christian spirit. Jean Fontaine-Vive liked to meditate, as the "Pilosus Artifex" of one of his somnets:

Mais le eanon s'éveille et hurle à pleine roix, Et lui, semeur de rêve en la brutale histoire, Reprenant l'anneau clair entre ses rules doigts, Cisèle un peu d'amour dans ee lambeau de gloire.

He has a noble piece, $U n$ Rêre, about William whom he represents as watching his phantom soldiers of Verdun march past; the reproaches

6 The Cinq Prieres pour temps de guerre. by Franeis Jammes, the gentle author of Les Géorgiques cliréticnnes, must not be forgotten here. They are, however, written in prose. 
which he reads in their eyes fill him with terror, and he tries to take refuge in death. But,

Il vit montant la garde du trépas,

Un soldat de Verdun croisant la baïonette,

Lui crier: On ne passe pas!

(Dated, August, 1916).

Another energetic poem is called Sonate contre Romain Rolland. . . . If only Rolland had died after his Jean Christophe!

Plût à Dieu que brisant son archet trop sonore Dans un suprême aecord d'espérance et d'amour, Le divin Jean-Christophe ait clos ses yeux au jour Et trouvé le trépas dont un peuple l'honore.

Mais

Jean-Christophe a rejoint la 'Foire sur la Place,' Son archet fait danser d'un entrechat cocasse Le neutre dont la poche a des eliquetis d'or.

The poet's preference, in his songs, goes most of the time to his splendid brothers in arms (see the Ode à mon Régiment). The general inspiration of the whole collection is well expressed in these few lines from the Ode aux Morts de Verdun:

Quand n'ayant plus que Dieu pour unique espérance, Plus qu'un désir, la mort, plus qu'un amour, la France, 
Le soldat accablé s'incline pour mourir,

Il ouvre lourdement ses ardentes prinelles

Pour qu'une ultime fois vienne s'y réfléehir

Le eiel de la patrie aux doneeurs maternelles,

Puis il meurt où son chef le met en sentinelle. . . .

A place by itself must be made for Max Leclere, not only on account of the originality of his inspiration, but also beeause the delightful Anjou dialect which he uses gives to his poetry a flavor of its own. ${ }^{\top}$

The little gem called La Passion de Notre Frère le Poilu was first published in the Echo de Paris, at once gaining reeognition. The "Société des Gens-de-Lettres" soon awarded it the Prix Jean Revel, 1916 (an meilleur ouvrage régionaliste). It has been since issued in a separate edition, with Préface by R. Bazin (22 pages).

The poet tells the naïve and touching story of a poor "Poilu" from Anjou:

C'était un paurr' bougr' de Poilu Qui s'en allait sous la mitraille. . . .

Vantié ben que n'aurait voulu Etre en aut'part qu'en la bataille; Mais du moment qu'fallait qu'î n'y aille, Ben, î n'y allait, tout simplement. . . .

7 He had written poems in dialect before the war. 
Our modest hero falls in an attack, and soon, the wound being mortal, he passes away. He bids good-bye to the comrades,

Pis, ayant dit son testament,

I rendit son âm' tout douc'ment.

He goes and knocks at the door of Paradise, Saint Peter introduces him before the Almighty who is seated upon the judgment throne surrounded by his warrior saints, St. George, St. Hubert, St. Michel, St. Charlemagne, St. Martin, St. Maurice, Ste. Joan of Arc, and the men who have recently come from the battlefield. The "Poilu" is not a little nervous,

\section{Y a des chane' que j'vas écoper.}

But he presents his case in a modest and goodnatured way to "l'Bon Gieu" and with a good bit of peasant astuteness. The great Judge is not too terrible after all; the hearing finally comes to an end:

Et roilà que l'Bon Gieu sourit, .

Et qu'd'arrièr' lui le ciel s'ouvrit.

And, as the man enters, he finds a great many "Poilus"' like himself : 


\section{POETRY OF THE WAR}

Et l'poilu s'assit dans la foule

En ehantant d'tout coeur avec eux:

Gloire à Dieu au plus haut des Cieux!

The whole poem is a marvelous imitation of the naïve and witty mediural Contes Dévots, such as those of Rutebenf.

Leelere has written, besides, a little volume, Les Souvenirs de Tranchée d'un Poilu (1917, 54 pages) bearing the same stamp of gentleness, of genuineness, and of simple but solid religious beauty. In lis last poem, for instance, he dreams of peace which must eome some day, but has not come yet: quand sonn'ront les Cloches!

V'là pus d'trent' moès qu'sus la Vallée, Ein soèr d'Aout, qu'on n'oubliera plus,

Les eloeh's sonnèr'nt à tout'volée

Le tocsin en lieu d'Angélus. . . .

Trent'moès déjà qu'on est en guerre, Tren'moès déjà qu'on est partis. . . .

And then he lets himself go,

Et j'rêv' du jour où tout'nos peines S'ront eun' bonn' foès payées de r'tour.

I pourra s'yasser ben des s'maines Avant qu'î vienne, l'temps du r'tour. . . . 


\section{But,}

I vindra p'têt' sans qu'on y pense, P't'êt' ben pus tard, p'têt' ben pus tôt. . . .

C'est pour la Libarté d'la France

Qu'en l'espérant j'payons l'impôt,

L'impôt du sang et d'la souffrance:

On tiendra ben tant qu'î faudra!

Tant qu'î faudra, on l'attendra,

L'jour de bonheur où qu'on r'vîndra,

Et qu'pour toujours, sus la Vallée,

Nos vieux elouchers, qu'on n'quittra plus

Chantront dans l'soèr à tout'volée,

La bell'chanson des Angélus!

* * * *

The embarrassment is great now, when it comes to speaking about the volumes of plain war poems, which are simply beautiful, and for this reason require no comment and no praise. It would be presuming much to claim that no good collection has escaped our notice, and even if this were the case, who would dare to claim to have made the best selection? Nowhere more than here would subjectivism play a part of undue importance. Let us therefore be cautious. It is safe, however, to say that many would cast their votes in favor of one or more of the few following collections: Julien Vocance, Cent Visions de Guerre (first published in the Grande 
Revue); G. Champenois, A la gloir de l'Armíe Française (erowned by the Acadtemie des Jeux Floraux de Toulouse) and Le Mirncle Frangais (with a preface by Le Braz); (iilles Nomand, Voix dans la Fournaise: Andri Alexandre (a worthy and clever follower of Déroulede), Chansons pour les Poilus; Ina, Poèmes; R. Apollinaire, Calligrammes, Poèmes de la P'air et de la Guerre 1913 à 1916 (some may call them disconcerting, some, original): Paul Verlet, De la Boue sous le Ciel; Edmond Fleg, Le Mur des Pleurs; Boyer d'Agen, Sept Paralipomènes à la Divine Comédie; Jean Suberville, Le fifre de Bertrandoux, and La Fosse aux Lions. ${ }^{8}$

Plongé dans la fosse funeste, J'ai rugi ces ver's sans remords:

En souvenir des lions morts, Je les offre aux lions qui restent.

All that really can be done further here, in order to give an idea of the general tone of this

8 For more such collections, see Yew International Year-book, articles "French Literature" (1914 and ff.), and Vie, op. cit. pp. $7+5-750$.

Some anthologies have been published, as: Les Poètes de la Guerre, selected by G. Turpin (Fishbacher); Les loètes de la Guerre, Recueil de Pósics parues depuis le 1 août, 191\%, selection made ly H. Delorme: all well known poets, such as Aicard, Bouchor, Dorchain, Fort, Noailles, Rostand, etc. (Berger-1,evrault): Cinquante Poèmes à dire, parus depuis le 1 aont, 1914 (ibid.), ete. 
war poetry while avoiding endless repetition, is to pick out two collections representing the two great types of the Lyrism of the Great War. The two volumes selected are mere samples; others might have served the same purpose, might contain even better poems. We recall that we deal here only with war poems by soldiers.

The first is En ces Jours déchirants, by Henri Dérieux (1916). The life in the trenches, horror, death, victory ... is sung in beautiful, : lassical rhythm, in "style noble." It is the France of the great writers which speaks, moved but dignified,

.. puisque débordé, le torrent germanique A roulé son impur limon

Jusqu' au temple, gardien de la sagesse antique Qu'ont bâti les Francs au beau nom.

The struggle against the Teutonic hordes is hard and will be long; but this struggle will once more bring before the world the heroic virtues of the French people:

Le labeur est dur et s'acharne,

On fait violence au destin.

Mais pareil aux jours de la Marne

Nous attendons le clair matin,

Où, brisant le moule, orgueilleuse, 330 
Du fond de la fosse boneuse,

A nos yeux ravis surgira,

Faite de vertige et de glaise

Une Samothrace française

Dont l'élan nous consolera.

With Dérieux, it is a theory that poetry ought not to allow its rhythm of beauty to yield to the ugliness, madness, and barbarity suggested by war and its chaos. Dérieus wishes to be "parnassian," “impeceable." Who would not be reminded of Théophile Gautier, for instance, in this description of the battlefield?

Les bois, printannières retraites

Oit nous songions.

Ne montrent plus que des squelettes

Ou des moignons.

Les maisons font des tas de plâtre

Affreux ì roir.

Regardez la place de l'âtre

Narquée de noir.

Pas un lieu qui n’ait crié grâce,

En vain d'ailleur's!

Partout le laboureur fait place

Au fossoyeur.

Still the soldier of France is willing to forget all this if, 
FRENCH LITERATURE OF THE GREAT WAR

\author{
Oubliant la nuit éternelle, \\ Et le tombeau, \\ Il voit la victoire fidèle, \\ A son drapeau.
}

Let us add that Dérieux is anxious that his judgment, as well as the form of his poems, should remain unaffected by the violence of the feelings which the conduct of the Germans has stirred up. If there was ever anything good in Germany, that good it is still legitimate to cherish. And he writes (VII) :

D'autres ont dit: C'est l'heure où l'esprit se délivre Du joug abhorré d'Outre-Rhin, Et leur main vous chassait de la cité du livre Divinités du ciel germain. . . .

He, Dérieux, he will not give up Goethe, "pur amant de la divine règle," Kant "aux férules de fer," Heine "'au coeur d'enfant," Nietzsche "au regard d'aigle," "Vous Beethoven-et toi, Wagner!", э

* $\quad * \quad *$

In contrast to Dérieux, we take HenryJacques and his volume Tous! . . . de la guerre, Poèmes (1918). He does try to make poetical

9 There are two poets by the name Dérieux; the other wrote the Livre d'Heures de la Guerre (1918). 
capital out of ugliness, tragic horror, atrociuts war-scenery. He has becn described quite appropriately by Vidal (in the Preface to the book) as " à eoup sûr le Barbusse de la poésie née de la crise épouvantable, qui cn prose, donna Le Feu." To Henry--Jacques the careful art of polishing the line when he wants to express the depths of his shocked soul, seems absurd: the terrible beanty of war is in the expression of the spontaneous, disorderly emotion. The description of Vidal is cxcellent, and we borrow it from him: "Chez lui le vers jaillit d'un bond, tel un sanglier, du taillis des sentiments; la rime fait ce qu'clle peut, homophonique à peine, hardie, se riant de la consonne d'appui, du plaisir de l'oeil, de la fraternité des singuliers et des pluriels; la règle de l'e muet se voit négligée, le décompte des syllabes dans une mesure est anarchique, eneore que certains alcxandrins chantent selon les codes avec une largeur toute classique; la césure souvent à point, quelquefois trébuche; au vrai notre poète pratique le vers libre, mais prouve sa connaissance des prosodies traditionnelles." To sum up, if the Victoire de Samothrace of the Louvre is the Muse of Dérieux, Rude's disheveled Marseillaise on the Are de l'Etoile is that of Henry-Jacques. 


\section{FRENCH LITERATURE OF THE GREAT WAR}

Although all the poems of Henry-Jacques are perhaps not equally striking, most of them have a remarkable power:

La Tranchée vide,

De la mort, des haillons, de la crasse . . . voilà :

C'est sale et e'est triste.

Berceuse,

Dors mon gars, dors comme une brute,

Dors sur la paille sans remords,

Pareil aux morts.

L'obus passe . . . ça ne fait rien.

L'obus chante: do, soldat, do,

Dors mon gars, do. ...

Complainte,

C'est à mon tour d'être touché,

Cochon d'obus qui m'a couché.

Le long de mon échine

Du sang chaud dégouline;

Cochon d'obus qui m'a couché

C'est à mon tour d'être touché.

Autour de moi l'on va, l'on meurt

Sous un ciel gonflé de clameurs,

Déchiré de rafales,

De choes, de cris, de râles,

Sous un ciel gonflé de clameurs

Autour de moi, l'on va, l'on meurt. 
J'ai soif! Dans mon bidon pilus d'eau,

J'ai l'enfer qui court sous ma peat.

Ah, dans ma gorge siehe

Sentir conler la traiehe :

L'enfer galope sous ma peau,

Et mon bidon qui n'a plus d'eau. ...

H. moins 5. (How the soldier feels five minutes before going over the top.)

Regarde en toi-même un peu,

Sois plus grand de te connaître.

De ta guenille va naître

Comme une espèce de Dieu.

Regarde autour, dans la fosse

Tes copains, l'ardeur aux yeux,

Leur front jusqu'au ciel se hausse

De sentir la mort sur eux.

Voici que la mort vient, silenee jeunes hommes.

Eeoutons-la venir dans le jour où nous sommes,

Regardons-nous eneore et donnons-nous les mains,

Car lesquels, mes amis, seront virants demain. . . .

Quelquepart (The soldier has gone over the top).

Le coeur battant, le eerveau fout,

Je me suis jeté dans un trou

Sous la houle froide des balles.

Je ne sais même plus où je suis.

On m'a dit: Pars-je suis parti

Conme on se jette diuns un puits. 
Autour de moi, les camarades

-Je ne sais plus combien-couraient,

Hurlaient, tiraient;

Devant moi, je ne sais plus bien,

La ligne ardente des copains

S'est mise à fondre soudain. . . .

Neuf, sept, cinq, quatre,

Et puis encor

Deux autres que je vois s'abattre;

Et puis un antre encor

Qui s'assied, épuisé, mort.

Et me voici,

Tout seul dans la foumaise et la fumée,

Debout, ne sachant pas comment,

Mais vivant. ...

See also, Amour, Oraison funèbre, Le canon, Lo charnier, Stars and Stripes. ${ }^{10}$

10 As to the "Chansons de guerre"-which stand outside the province of this study-let us recall only that the most notable author, of course, has been Théodore Botrel (often called "Barde de l'armée," "Lauréat des tranchées," "Chantre de Rosalie") with his Chants du Bivouac (1 aô̂t, 1914 au 31 décembre, 1914), and Chansons de Route (53 songs, 34 with music). Also Montéhus, Chants de la Grande Guerre (1915). The Chants du Soldat, by Paul Déroulède, have been taken up again. Among other collections to be mentioned are, Chants du Soldat, 1525-1915; Autres Chants du Soldat (Chansons populaires, Chants de Route, Chants historiques et militaires), both collections edited by $\mathbf{R}$. Sauvresis; and Les Chansons de la Guerre,-all published by Berger-Levrault. Chants de Guerre des Enfants de France (Cantiques, Rondes et Chansons), collected by Jean Vézère. Hymnes et Chants Nationaux des Alliés (Hachette); and an excellent one, quite comprehensive, 336 


\section{POETRY OF THE WAR}

Marches et Chansons des soldats de France, by Jouvin, Gillet. Vidal et Penlevey, edited by Plon, 1919.

One might call attention to a reviral of the French chanson in the evening gatherings of the cafis (of which the American eabaret is a regrettable initation). (In this subject, consult an excellent article in lo(pinion. by Ernest Charles, Le Caveau et les Théâtres des Chansons (10 février, 1917). Touny Lérys, in . Mereure de France 16 février, 1919, writes on Quelques kixpressions de l'Ame Populaire pendant l'Uccupation Allemande; La chanson. 


\section{CHAPTER II}

\section{THE STAGE AND THE WAR}

THE theater is one of the best means of influencing public opinion. Thus one might have expected that the theater would play a foremost part during the war. It seldom did.

The best war-plays, indeed, were written before 1914. There are especially two spy dramas: One is Lavedan's Servir, in two acts, given almost on the eve of the war, in 1913; a prophetic play truly. And the other is Kistemaeker's $L a$ Flambée (known in English speaking countries under the title The Spy) which has more action, more spectacular drama in it, but which is not. more deeply patriotic than Servir. To show how well, even before the war, some men in France had not only foreseen what was coming, but had well anticipated the courageous attitude of the French during the war, let us quote just one short passage from Lavedan's play.

Colonel Eulin discusses with Madame Eulin 338 


\section{THE STAGE AND THE WAR}

the military profession of their three sons, one of whom has just been reported killed in the colonies :

Eulin. The soldier is a man apart. I have often told you so. Aceident is his opportunity, and eatastrophe his glory. Every danger which threatens him is a privilege; every evil which befalls him makes him greater. Therefore if we are to rise to the level of those marks of honor, we are to train our sons to every loftier sentiment. Since we have sons who are above the erowd of ordinary mortals, let us, their parents, show ourselves worthy of them.

Madame Eulin. How lightly you speak of the fate of your children.

Eulin. No, not lightly. But I must say that when I think of the possible death of some member of my family, it never strikes me as a calamity if I am sure that it will be beautiful.

Iadame Eulin. Parents know of no beautiful deaths of children.

Eulin. Some deaths are splendid ... and they are necessary.

IIadame Eulin. Why necessary?

Eulin. To prevent ugly ones-or to redeem them. Be prouder; bear your grief with raised head. . . . What really matters is not that one should live or die, but that one should die well. If I should die of disease, you may mourn if you wish, but if I fall with a bullet through my forehead, I forbid you to show any grief.

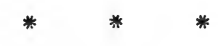


From 1914 to 1915, attempts were made to echo on the stage, as in the other domains of literature, the indignation against Germany's barbarism. In Nozière's Prière dans la Nuit, a loyal French woman of the invaded territory, who has married a naturalized German, discovers that she has given her love to a traitor, and she stabs him before he has time to do more harm. La Kommandantur, by Fronson (the Belgian author of the famous Mademoiselle Beulemans) is a painful description of the conditions in Belginm under German rule; it presents the story of the return to Brussels of a German officer whose love had been spurmed by a Belgian girl and who takes a cowardly vengeance by having the fiancé of the young woman shot; he also tries to force her; but she kills him. A third play of the same order is that of Soulié (1916), called 1914 à 193\%: a boy, an "cnfant du crime," son of a French woman of Northern France and of a German soldier of the Great War, meets his father in 1937 and strangles him.

It soon became clear that the public did not care for such performances: one may bear to read about such things, but one does not like to see them acted. This kind of play, therefore, 


\section{THE STAGE AND THE WAR}

ceased to be produeed : ${ }^{1}$ and it is worthy of note that the best one of them, though written in the earlier days of the war, was not acted until 1919, when a translation of it was presented at Springfield, Mass., and then in New York. We refer to Maeterlinek's Le Bourgmestre de Stilemonde. Maeterlinek refrains from any jingoism and his restraint adds to the force of the play. The subjeet is the atrocious act of "the most humane of the German officers," who has the Burgomaster of Stilemonde shot under the pretext of reprisal, but probably with the purpose of terrorization. ${ }^{2}$ A German officer had been assassinated in the town, and the evidence clearly pointed to one of his own men who hated him, as author of the aet. The Burgomaster is a splendid figure; he refuses to allow one of his gardeners who was plainly imnocent to be shot; he also refuses the offers of others who want to die in his place, while the Germans just shrug their shoulders at what appears to them a ridiculous piece of sentimentality. The Burgomaster aecepts his fate courageously, although in

1 For the two sides of the argument see lirisson's article on the Kommandantur in his Théatre pendant la guerre (1918) pp. 52-61. J. F. Fronson presents his own case.

2 Such a case actually occurred at Aershot. 


\section{FRENCH LITERATURE OF THE GREAT WAR}

despair because he leaves behind a very young boy, and also a daughter who had married a German lieutenant. The latter had left Stilemonde on the eve of the war, but had returned to his adopted town at the head of his victorious soldiers; when he shows himself unable or unwilling to save his father-in-law, he is rejected with scorn by the wife.

Less unwelcome than the actual "atrocity plays" during the first winter of the war, was the dramatization of Maurice Barrès's Colette Baudoche. It may be due to the excellence of the play itself or to the fact that the good cause was upheld without gruesome scenes, or again to the fact that the problem of Alsace-Lorraine was too near the heart of all Frenchmen to be ignored on the stage . . Paris seemed pleased to hear Colette make it so plain why, after forty years of annexation, there still could be no sympathy between the conquered and the conqueror.

Perhaps while waiting for more satisfactory war plays, the managers tried various revivals of former War-classies, like Corneille's Horace, Sardou's Patrie, Bornier's La Fille de Roland (which had in 1875 stirred up France still de- 


\section{THE STAGE AND THE WAR}

pressed by the defeat of 1870); also the once very popular drama whieh had filled with enthusiasm the patriots of 1848, Marceau, ou les Enfants de la République; and even the play from Dumas's lively. novel La Jeunesse des Mousquetaires. Then also, Erkman-Chatrian's delightful Alsatian play L'Ami Fritz. Sometimes they took up plays of the past which would offer a relaxation from the nervous tension, such as A. France's Le Crime de Sylvestre Bonnard, Meilhac et Haléry's Tricoche et Cacolet, and the abundant and ever acceptable répertoire of Molière. ${ }^{3}$

One of the most successful of these "reprises" was Kistemaeker's La Flambée. In 1918, however, this author gave a new spy-play, $C_{n}$ Soir au Front, in which a rather interesting attempt was made to define the Honor of the French soldier as contrasted with the Geman Military Duty. But, while some situations are very strong, the play is encumbered with theoretical discussions whieh are clearly not what the publie looks for in a war drama: A French woman has married a German who had been naturalized, and who, when the war broke out, had been forty

3 Zola's L'Assomoir was also revived on the stage; probably to support the Government's efforts to deal energetically with the alcohol question. 


\section{FRENCH LITERATURE OF THE GREAT WAR}

years in the country. He was a captain of the French army; but almost immediately after the outbreak of hostilities he had been reported missing. He had passed into the German lines, but came back from time to time in his French uniform for the purpose of spying. One night his wife, who had returned to her dilapidated residence, now used as military quarters, met him-and guessed the truth. Although his behavior and person inspired her with scorn and horror, she asked an officer whose life she had saved, and who knew the situation, to spare the traitor for her sake. Her request is heeded; but nevertheless the spy does not escape his deserved fate.

Really only one play, written directly under the inspiration of the war and during the war, and written in the tradition of the French theater of the last forty years, achieved genuine success. This is Bernstein's Elévation (presented for the first time in June, 1917). The idea of the drama,-regeneration by the war of a man of purely worldly ideals-had already by that time been often discussed. And some critics seem to have been angry because they were stirred in spite of themselvs by so commonplace a theme; yet they could not deny being 


\section{THE STAGE AND THE WAR}

moved. An idea, though not original, may none the less be beautiful; and the very fact that Bernstein sueceeded in moving deeply with a trite theme, is a distinet testimony to the power of his art. L'Elévation was written in an hospital at Saloniki while the author was reeovering from a wound;-he had served in the aviation corps.

\section{* $\quad * \quad *$}

The plays mentioned above were rather ambitious in so far as the authors seem to have aimed at writing regular, lasting plays on the ephemeral subjeet of the war. Such authors, who wrote in keeping well in mind that they were eatering to a publie laboring under very speeial conditions, sueeeeded better. There is really a good erop of what they eall in French "pièces de eireonstances."

Some are written in a light and cheerful mood. Some are of the serious kind.

The following belong to the first group: L'Impromptu du Paquetage, in one act, a delicate sketch by Mauriee Donnay. The stage represents an office for war-relief, to which eome various callers from the humbler classes; they tell their touehing and often heroie tales of selfsacrifice on the altal of the mother eountry 
FRENCH LITERATURE OF THE GREAT WAR

. . . ; we may mention here, by the same author, Le Théâtre aux Armées (1917), a play to be performed before the soldiers at the front. Players are discussing which would be the best topic for such a representation, and this discussion quite naturally introduces many pleasant appreciations of the soldiers' virtues, - and the actors decide to go on the stage and present just that discussion; Les Deux Gloires, by Pierre Wolf (published for the first time in the $A n$ nales, July, 1916) - "les deux gloires" being the veteran of 1870-71, and the "Poilu" of 1914 (a pretty love episode is woven into the play); Le Poilu, Comédie-opérette, in two acts, by M. Hennequin and P. Veber, music by H. M. Jacquet-is a very bright and graceful vaudeville. A young soldier falls in love with his "marraine" just from reading the letters she sends to the trenclies. He comes to Paris; complications arise; but all ends well.

Among the occasional plays in more serious mood, let us mention the following few: Le Gars, a beautiful little dialogue in verse, by Zamacoïs, which came out first in L'Illustration, and then in the author's volume L'Ineffaçable; Paul Claudel, La Nuit de Noël de 1914: it is a sort of one act mystery play, in 346 


\section{THE STAGE AND THE WAR}

verse, showing on the night commemorating the birth of the Divine Child, the murdered ehildren of Belgium and Northem France who arrive in Paradise-from which place of delight they look down on the sufferings of the world. It is a moving indictment from the moutls of the innoeents, recalling several eoncrete instances of German barbarity.

La Vierge de Lutèce, by A. Villeroy (Librairie Theâtrale) represented at the Théâtre Sarah Bernhardt, June 29, 1915, is a dramatie presentation of the legend of Sainte Genevière, the patron-saint of Paris who saved the city from the Huns in the fifth century. The allusions to the events of the Great War are clear to all: "Ils ne passeront pas!" exclaims Sainte Geneviève; "La eivilisation, e'est moi!" says Attila; and when Aetius, the commander of the army which defends Paris, gives his order of the day for the decisive battle, he does so in the words of Marshal Joffre's famous proelamation, on the 5th of September, 1914: "Le moment n'est plus de regarder en arrière... Quiconque ne pourra plus avancer a J'ordre de garder le terrain conquis... il se fera tuer sans reeuler d'un pas. . . .' At the end, Sainte Geneviève is solemnly admonished by the Bishop 
Germain l'Auxerrois to "continuer à veiller sur la ville endormie." 4

Several plays were specially written for Sarah Bernhardt. We will mention only one: Eugène Moraud's very spectacular Les Cathédrales, in fine verse (Novembcr, 1916, Théâtre Sarah Bernhardt). In a gray cloud, five nuns representing the cathedrals of five French regions are bemoaning the tragic events of the war. They are, Notre Dame de Paris, Saint Pol de Léon, Bourges, Amiens, Arles-and later are seen the two martyr cathedrals, Reims and Strassbourg. Maledictions and prophecies of divine punishments against the invaders are interpreted with all the passion at the command of Madame Sarah Bernhardt-who impersonates Strassbourg. There are other plays of that kind ; such, for instance, as L'Eternelle Présence, written by the poet André Dumas for the commemoration of the Battle of the Marne, at the Comédie Française, in 1917 ; or, as Lavedan and

4 A poetical staging of the great Serbian drama will be found in Maurice Allan's La Main qui tend l'Epée, two acts (June, 1918). The play is interspersed with tragic patriotic songs; it was staged in a very picturesque manner, and meant to be an appeal for sympathy for the victims of a ferocious foe.

The "drame lyrique," Jeanne d'Arc, by Raymond Roze (presented in the winter 1917-18) being all music, lies, of course, outside the subject of this study. 
Zamacoïs's Les Suacrifices (Les Flandres, Nö̈l, Reims, Poème dramatique en trois tableaux (1918); the first "tableau" is a picture of refugees fleeing before the invaders; the seeond, a Christmas in the trenches; and the third, a sort of monologue by the Rheims eathedral, evoking the memory of Joan of Arc and of the heroic cohorts in horizon-blue uniform. The "poème" was not presented."

* $\quad * \quad *$

Nore ambitious than all the preeeding playsbut still indisputably a "pièce de circonstance" is Franejois Porchés Les Putors et la Finette. The author was already well known by a fine poem, l'Arrêt sur la Marne. The play-four acts, six tableaux, in verse-was presented for the first time on November 29, 1917, at the Théâtre Antoine, and created quite a sensation. It is an allegorical history of the war. The Miron family (this means the French people) are cultivating a beantiful garden for Princesse Finette (France), whose graceful kindness and genuineness of heart have been responsible for

5 Professor Ferdinand Brunot wrote La Défense de Schirmeck, a series of patriotie tableanx in reconquered Alsace (five acts). It was meant to be played by the people, following the idea of Maurice Pottecher in the Théatre du Peuple, in Bussang, Lorraine. 
her blind confidence in the foreigner Buq, the superintendent of the domain, and a master spy. The Butors (the "Pig-headed" ones, as poetic a name as could be found for the Huns) invaded the domain just as every one was preparing for festivities. . . During the war, the enemy proposes to Finette a luring but deceitful peace; but she has enough sense, and especially pride, to refuse. And finally François Miron, the impersonation of the chivalrous people of France, frees the country of the foe and becomes the lord of the fine lady. As to Buq, the traitor, he has paid with his life for his shameful and contemptible behavior. Victory has not been achieved without heavy sacrifices, but, free from the fear of invasion, Finette's people again set about cultivating the beautiful garden of France. ${ }^{6}$

What shall we say about the claim of Porché : "En écrivant Les Butors et la Finette nous n'avons prétendu à rien moins qu' à renouveler la scène. L'avenir seul dira si, nous avons réussi"? (P. 9.) Does he mean that the theater

${ }_{6}$ The poetical figure which represents France as a fine garden entrusted to her people had been beautifully worked out by Péguy in his Porche du Ilystère de la Deuxième Vertu (1911). There can be no doubt that Porché knew about it, and made that the starting point of his allegorical play, since he published in 1914 a little book, Péguy et les Cahiers. 


\section{THE STAGE AND THE WAR}

ought to be inspired more by patriotic preoceupations? In that case he could hardly claim to have put forth an original idea. Or does he suggest going back once more to the "genre allégorique" whieh flourished in the days of the Roman de la Rose? The success of Les Cathédrales might, perhaps, support the view that the public is not insensible to that sort of poetical language. Indeed, another attempt to abandon the realistic and the concrete, in favor of the ideal and the abstraet, was made almost at the same time as Porché gave his Les Butors et la Finette, when the "Theître des Alliés" founded by M. Jean Billaud with the purpose of propaganda during and after the war, gave as its first production Les Epis Rouges by Emile Sicard, the Provençal poet. This work is an elaborately staged "Poème dramatique" in four acts, some parts of whieh are set to music. The author has aimed less at presenting regular scenes than tableaux representing the days of mobilization; women waiting with anguish for news of the front; a night of spectacular war display at Verdun, etc. And the characters are not so much individuals as abstractions: tho mother, the betrothed, the ancestor, the warrior, etc. While Les Epis Rouges cannot be said to 
have been a failure, it certainly did not take the public by storm.

However one looks at that special question it does not seem that we have in Porché something so very different from other "pièces de circonstances," except that his play was much more elaborate; possibly, posterity will agree with the verdict of Ernest Charles, that Porché has given a "pièce pas négligeable," while so many others are "négligeables" (Opinion, 4 janvier, 1918). A proof that Porché was determined to continue his efforts in that direction is found in the fact that he has since given another play $L a$ Jeune Fille aux Joues Roses (Théâtre Sarah Bermhardt, March 16, 1919). It suggests a reform of France after the war, and is again in the form of an allegory. In the country of the Pale-cheeked, oppressed by laws and etiquette, crushed under bureaucracy, suffering from the learning and pedantry of its rulers, appears one day the "Girl with Rosy Cheeks." ... She scandalizes the old wigs, men and women, with her impulsive manners and her unsophisticated ways of thinking and speaking. But thanks to these very things she finds her way to the heart of the Prince of that gloomy land. After many adventures, tragic at times, allegorical always, 
the Prince marries the Girl. The satire which was meant to be biting is not dangerous after all ; this play, like the preeeding one, rather lacks body. Rostand had more power associated with his wit. ${ }^{7}$

* * * *

This would be the place probably to say something about the theater in the trenches. Mueh interest has been shown for it; yet very seanty information is on haud. Some day perhaps, if a writer finds time to do it before it is too late and before the doeuments are too hopelessly seattered, we may know more. It may be permitted,

7 The attitude of erities toward the second playand, through the second. even toward the first-can be gathered from an amusing article by Billotey, in Les Marges (an influential review of young authors) in June, 1919. The eritic pretends that Porché came to interview him about a new play he had in preparation, Le Lapin blanc sur les Flots noirs. Porché is supposed to explain thus: "Quel symbole, monsieur, quel symbole!... Aete premier: la naissance du lapin a ĭoscou. Deuxième acte: le lapin s'installe en France et il y remplace le veau dor. Troisieme acte: la cour et le bonheur du lapin bleı. Quatrième acte: guerre et révolution. Cinquième acte: la scène représente un vaisseau de haut bord. C'est la dette flottante qui vogue vers l'Iearie. Le lapin bleu s'y est réfugie aree sa suite et dit: C"est ici que je roudrais virre.

"Permettez," then says M. Billotey-"le dernier vers n'est pas de vous. Ft je sujet même de la pièce appartient à un auteur défunt."

"Qu'importe."-answers Porché,--."Je l'ai trouvé tout seul. On m’a déjà reproché bien des réminiseences. Je m'en moque. Quand on travaille aussi vite que moi, on n'éehappe pas ì eet ineon rénient la." 


\section{FRENCH LITERATURE OF THE GREAT WAR}

however, to doubt whether many of these occasional plays written by the soldiers will offer lasting literary value, and whether the study would not be rather of an historical or psychological value as showing the spirit that prevailed among the soldiers of the war. A few probably will be found worth preserving, as, for instance, the pretty little dialogue by Jean Suberville, caporal mitrailleur au $94^{\circ}$ d'Infanterie, Cyrano de Bergerac aux Tranchées. When it was printed, the little' play was honored by a short "Lettre-Préface", by Edmond Rostand. Soldiers represented it on the "Théâtre Chantecler" of the " $32^{\circ}$ Corps d'armée", which gave two hundred and fifty performances during thirteen months. Cyrano comes to our planet, in his fall almost pitching through the wings of "un papillon énorme qui passait," and seeing very queer "gros hannetons aux bourdonnantes élîtres"' (air torpedoes). In finding soldiers of France hiding in holes in the ground he is shocked terribly:

Le temps a-t-il changé les Français héroïques?

To which the "Poilu" answers, well conscious that he has nothing to be ashamed of:

Ils sont ce qu'ils étaient, en étant plus pratiques!

$$
354
$$




\section{THE STAGE AND THE WAR}

Ce qui change, c'est la manière, pas l'élan! Vous autres, vous faisiez la guerre en rigolant!

Ça ne durait qu'un an vos batailles gentilles! Vos canons ne lançaient que des bonles de quilles! Puis quand vous revenicz dans vos nobles salons, Les dames se haussaient au bout de leurs talons. . . .

Nons qui sommes vêtus de boue, admirez-nous!

Nous qui ne portons pas de plumet, mais des poux,

Je crois que nous valons encore nos aïeux;

Que, s'ils furent plus beaux, ils ne firent pas mieux. ...

And Cyrano understands:

Et je te reconnais, France des mousquetaires,

Dans la France de ces Poilus!

(The reader may be referred for some information on the early days of the Theâtre aux Tran. chées, to an article in the Revue Internationale de Sociologie, of November, 1915.)

We come now to a group of writers who borrowed materials from the war, but endeavored to remain entirely indifferent to the patriotic side of their plots. They are war-plays without the war spirit. They are not unpatriotic in purpose, merely a-patriotic. At the same time they are unpleasant-and if not atrocity plays, surely most of them are atrocious plays. 


\section{FRENCH LITERATURE OF THE GREAT WAR}

A good deal has been said about the unsettled state of moral standards during and after a war; and the question has been more than once asked, how far should the social obligations of normal times be considered binding? These plays are a few samples illustrating such preoccupations. L'Amazone (1915) by Bataille, is the painful story of a girl of the invaded provinees, who, having seen her whole family slaughtered, gets into a state of patriotic frenzy which in the milieu where she has taken refuge, proves to be contagious; she makes use of her womanly charms to induce the husband of her friend to join the army as voluntcer; then, later, when she wants to marry another, the wife of the soldier maintains that she has no right to do so, since she is now morally bound to the man who went to war on her account; she accepts that view.

A somewhat analogous situation is sketched in Marcel L'Herbier's L'Enfant du Mort (1917). In André Couvreur's Plus haut que l'Amour (1916), the heroine appears again as if completely at a loss when she has to decide on her line of conduct in love-affairs; she acts according to the inspiration of the moment, now ignoring the love of a man whom she knows to be worthy of her, now throwing herself away on a 


\section{THE STAGE AND THE WAR}

man who turns out to be a spy, and then finally taking refuge in the arms of the strong man who had proteeted her from the beginning. In Vernet et Delamarre's L'autre C'ombat, a woman in a moment of self-saerifice marries a blind soldier to whom she had been betrothed though she did not love him; she then betrays him; and finally she repents. ... In 1917 the Comédie Française presented Francis de Croisset's D'un Jour à l'Autre, another keen study of a woman charaeter during the war. This heroine hesitates whether to give her love to a fashionable mondain who has been divoreed, to a business man who has grown rich through the war, or to a fascinating hero of aviation-she decides for the last, but only after long deliberation. One ean easily reeognize the style of the man who shortly before the war had written L'Épervier (The Hauk).

Porto-Riche's gruesome drama, Le Marchand d'Estampes (1917), is the most powerful of those deseriptions of normal moral lives which are shattered in consequenee of the war: Aubertin was a quiet lover of art, selling engravings, leading a model life as husband and tradesman, in his little shop. Then he joins the eolors. In the crude, natural, almost animal life of the trenches, 


\section{FRENCH LITERATURE OF THE GREAT WAR}

his lower, bestial instincts are re-awakened and take the upper hand; so that, when he returns home, wounded, he falls in love (sensual love) at first sight, with a woman of the neighborhood (who is never seen on the stage). He retains, however, enough decency to realize the uncleanness of his passion, and to be profoundly unhappy about it. He does not want to do any wrong to the devoted companion of his life. She, too, is plunged in deep grief, and, finally, they both go together and throw themselves in the Seine,-he, so as not to be unfaithful to his wife, she, so as not to be separated from her husband.

Less gloomy-and more generously inspiredis Laudenbach's Le Sacrifice (1918); the author expresses the idea that war ought to reflect on the whole life of the soldier, making him chivalrous not only in his military activities but at all times. With all its loftiness of purpose, Le Sacrifice is, after all, a "triangle play" of the trenclies.

Having even more clearly the characteristics of a "triangle play" but one written by two skillful craftsmen of the stage, is La Veillée d'Armes, by Claude Farrère and Louis Népoty (Gymnase, Jan. 5, 1917). The scene is first on 


\section{THE STAGE AND THE WAR}

a small vessel, the Alma, a scouting eruiser. Captain Corlaix, 50 years of age, has a young wife of 23, Jeanne. She is a pretty woman, not bad at heart but made of the eommon clay, and she regards him as a father rather than a husband. She loves d'Artelles, first lieutenant of the ship. There is a farewell dinner on board; they all expect war, and the men are eager to start. At 11 c'elock an order arrives, however, to remain for the present in Toulon, although war is now unavoidable. Jeanne and her sister must leave the boat, but Jeanne finds at the last minute some pretext-a lost vanity bag-to remain, and she spends the night in the room of d'Ardelles, expeeting to leave by the 6 o'elock rowboat. But a counter order arrives, and the vessel sails. . . . In the morning, d'Ardelles finds with dismay that they are at sea, with the woman aboard. They' are attacked by a German torpedo boat, which has used French code signals to lure the Alma to its destruetion. The Alma is sinking. Corlaix is wounded; he thinks he is lost. D'Ardelles dies in trying to save Jeanne, and entrusts her to the eare of his orderly. She sueceeds in returning home, without any one except her sister suspeeting what has happened to her. Corlaix also 
is saved and recovers. But then he is summoned before a court-martial to answer for the loss of his vessel. There is no witness to prove that the enemy used French signals; only two officers have survived, Corlaix himself, and Bramburg, a somewhat suspicious character, possibly a spy, who is in love with Jeanne but whom she hates. Under the pretext of amnesia, he declares himself unable to testify either way. Jeanne, in order to save Corlaix, intervenes. She has a means of forcing Bramburg to admit that he knows that the Germans used French signals :- of course, by doing this, she must own to the fact that she was on the vessel. Corlaix understands all; and,rather as father and daughter now,--they shake hands and return home. La Veillée d'Armes is a strong drama, in which, however, the war has no essential part.

* * * *

As the war proceeded, and its gloomiest days were succeeded by more hopeful ones, especially after the entrance of America, the theater ceased to be used as a means of inspiring the people. There are still plays recalling the war, of course, such as the humorous Beulemans à Marseilles (1918) in which Fronson revires his famous Belrian characters made up of pathos and joviality; 360 


\section{THE STAGE AND THE WAR}

or, as Jacques Richepin's "cocardier" play, La Guerre et l'Amour, Pièce hérö̈que, en quatre actes et en vers (1918) ; or, such as Sacha Guitry's L'Archevêue et son Fils (1918), in which the author seems to think that the war was made to give him material for witty but flippant stage effects, (the play reminds onc somewhat of Mérimée's Carosse du Saint Sacrement). Antewar plays, it is true, continued to be given after the spring of 1917 and proved that the war was still in the minds of the people; but oftentimes the connection between the preaccupation of the hour and the stage seems to be a very slight one. In l'Abbé Constantin, for instance, which was revived at that time, the presence of two American (or Canadian) women, and of a young French officer, is the only reminder of contemporary events. Meanwhile, plays which ignore the war altogether become more and more numerous; Sacha Guitry offers L'Illusioniste, Géraldy, Les Noces d'Argent (which was written before the war), and Lucien Guitry, Le Père. ${ }^{8}$

8 For more information regarding the French Theater in war time, the reader is referred to Brisson, Le Thêatre pendant le guerre (1918), a collection of his artieles in Le Temps. A book which discusses the possible forms of the drama after the war is Alfred Mortier's Dramaturgie de I'aris. The title is evidently 
There is one play which will probably not be presented on the French stage for some time to come, but which may be mentioned as a curiosity, Romain Rolland's Lisuli (Geneva, 1919). The pacifist of 1914 is anxious to show that he has not changed his views and is still willing to challenge the world that this war was absurd. He still refuses to draw any distinction between the Central Powers, who yielded to the folly of war because they wanted to do so, and the Allies, who waged war in order to exterminate the war spirit from the surface of the earth: Any war is folly! Lisuli is the goddess of illusion, who persuades men, and especially youth, that war can be a noble thing. ... When the curtain falls, this belief has brought about a formidable crash, and on a heap of ruins sits triumphantly Lisuli, her tongue out and her finger to her nose.

chosen in remembrance of, and in opposition to, Lessing's Hamburgische Dramaturgie: The pessimism of the generation of 1870 will not survive, and the "Theatre herroïque" will come. What is this to be? "Prose drama, philosophical synthesis, the great epic pictures of modern society, the vast problems of the new world, symbols, the acting of the 'groupes' in their 'activité totale,' mob psychology, or, again, a fanciful Fortune playing allegorically with human destinies; or, even farce if it be 'grandiose'-all those will be part of the Théntre héroĩque. ..." If the Théatre héroïque is to be so many things, would it not have been simpler to state what it is not going to be? (F. Vanderem, in Figaro, August 19, 1918, also discusses the Théatre d'après Guerre. See also Vic, op. cit. pp. 643-4). 


\section{III}

\section{War-Time Fiction}

In our First Part, Chapter II, we made a distinction between "War-novels"-like Gaspard, Bourru de Vauquois, Le Feu, etc.,-which offered actual war experienees in the form of fiction, and thus are real war documents, and "War-Time novels" which were written by authors who do not use personal recollections, but chicfly their own creative talents, and who moreover often use war only because it provides excellent material for thrilling stories. We have already dealt with the first class.

Abstractly speaking, the second class-wartime novels-offers better opportunities to the real artist in so far as it allows more play to the individuality of the writer. Yet, from 1914 to 1918, war-time fiction has proved to be rather insignificant. We need, therefore, devote to it only a short chapter. Less than anywhere else do we aim here at being exhaustive, and we refer the reader once more to the eatalogue by Vic, op. cit. 
We consider this insignificance an entirely normal phenomenon. Fiction ought to be resorted to only when reality does not offer better material; and things being so, it is by no means a paradox, but a natural and plain truth, that the best war-time fiction-as well as the best warplays-had been written before the war. No fiction written during the war has proved equal to Bazin's Les Oberlé (1901), "Maurice Barrès's Colette Baudoche (1912), or Lichtenberger's Juste Lobel, l'Alsacien (1913), - all on the question of Alsace-Lorraine; Prévost's Les Anges Gardiens (1912),- - on the spy question; P. Margueritte's Les Frontières du Coeur (1912), -on FrancoGerman marriages; not to speak of Zola's $D$ ébâcle (1892), and the Brothers Margueritte's series L'Epoque (Le Désastre, 1897, Tronçons du Glaive, 1900, Braves Gens, 1901, Commune, 1902), which, although borrowing material from the Franco-Prussian war, were written with the future in nind.

$$
\text { * * * * }
$$

Certainly one of the best war-time novels is Marcel Prévost's L'Adjudant Benoît (1916). It is the story of a young officer who falls in

1 Bazin has published during the war La Closerie de Champdolent (1917), and since the war Les Nouveaux oberlé. Our remark applies in both cases. 


\section{TAR-TIME FICTION}

love with the danghter of a dangerous spy on the frontier, of Lorraine. The spy poses as a veteran of 1870-i1. Ile had taken part in the war, but on the German side. Adjudant Benoit one day discovers the real nature of the man, who receives him in his little house to get, if possible, information. He kills him. 'The daughter' is hit by a shell a few hours later when the Germans invade the country: she dies however in ignorance of the erime of her father. The suffering of Adjudant Benoît in doing what, as a soldier, he has to do, and then eoncealing the truth from the woman he loves, is admirably described in Prévost's best style. But if it fails to stir us it is simply beeause one eannot help thinking that there have been real dramas as moving, and more so:-fietion is not interesting under sueh eireumstances as prevailed when Prérost wrote, and if Prévost did not-sueceed-uho could? ${ }^{2}$

There are other spy novels. One by Léon

$2 \mathrm{~A}$ war-time novel as broadly eonceived and an ambitious in every way as H. (i. Wells's Mr. Britling sees It Through, or Ibañez's The Four Horsemen of the Apocalypse had not yet been attempted in France when the war ended, unless one wishes to reckon ats such les Fresques de Feu et de sang, by Francois de la Guérinière, in three volumes (La kiultưr déchaînée, Les sillons de la Gloire, L'Arc-en-Ciel). 
Daudet, La Vermine du Monde-in which the author uses the material of his book L'Avantguerre mentioned elsewhere; as a novel it is very commonplace, and the documents are more interesting as presented in the original work. ${ }^{3}$ Another is Marthe Steiner, by Avèze, the gruesome story of an "ange gardien": the woman-spy puts out the eyes of the father of a boy entrusted to her care, and has the child killed. A. de Villèle, Allemand d'Amérique (1918) tells of pre-war German propaganda in New York,-quite plausible in the light of what we know.

Paul Margueritte likes to deal with problems. In 1916, he published l'Embusqué, the story of a man who eludes his military duties and hides in Paris with a woman. That woman's husband, however, who had served his country as a soldier, returns, and the wife, realizing how far superior he is to the other, abandons her cowardly lover. In La Terre Natale (1917), Margueritte tells of two brothers who were of military age at the outbreak of hostilities, one of whom had been brought up in France, and the other in Ar-

3 Léon Daudet has another novel, Le Coeur et l'Ab. sence, the romantic story of a woman who, thinking that her husband has died in the war, yields to his former friend whom she loves-but the husband comes back and the book ends with a tragedy. 


\section{WAR-TIME FICTION}

gentina. The first one alone is morally prepared for the emergeney of the Great War. In 1918, the same author published Pour la. Patrie, and in the same year, Jouir, a two volume novel in which he pours contempt on the despicable eonduct of the "fêtards" of Nice and other society resorts, whose unconcern with the great problems of mankind brands them as responsible for the fearful cataclysm.

(The author died in the last days of 1918.)

Another prolifie author-whose name it would probably not do to omit-is Ch.-II. Hirsch, a man who has, ever since he began to write, more than twenty years ago, wasted really remarkable gifts, by a too abundant output. His Mariée en 1914 tells how people who existed in a sort of irresponsible way before the war, have now been compelled to look facts in the face. The book is altogether laeking in cheerfulness. Chacun son Devoir (1915) takes up again a war situation of a very depressing nature. (Hirsch belongs to the generation which believed that it was a sign of superiority to paint life as gruesome.) In 1917 Hirseh produeed still another book, La grande Capricieuse-Death.

Of a higher quality, because the authors are more spontaneously tragic, and the reader feels 


\section{FRENCH LITERATURE OF THE GREAT WAR}

less the determination to write despondent stories, are Ch. Géniaux, Les Fiancés de 1914, E. Moselly, Le Journal de Gottfried Mauser, and Roland Dorgelès, Les Croix de Bois. They are only novels, but three of the finest of those years. The last named was awarded the much coveted "Prix de la Vie Heureuse" for 1919, and pronounced by some much superior to Le Feu.

The fact that it was prefaced by Barbusse may account, perhaps, for some of the success of Cyril Berger's Pendant qu'il se bat (1918): the story of a soldier, very devoted in his service but unable to get any recognition for it-who finds compensations of some sort in the love of a good woman; and Louis L. Martin's Jean Denys (1918) also deals with a painful psychological case supposed to be brought about by the war.

In very many instances, the war is nothing but a sort of necessary seasoning to the literary dish of the day; the novelists use the war merely to get people to look at their wares-as liquor dealers sometimes put bells and garlands in their show windows at Christmas time. Such is the case of the agreeable and abundant François de Nion: the scenes of Pendant la Guerre (1915) are placed successively in Holland, in Germany, in France, 


\section{WAR-TIME FICTION}

and these various milieus are pictured probably more by ehic than by observation. Som Sang pour l'Alsace (1916), by the same author, is one of the numerous stories of love between a wounded soldier and his nurse, and elaims to present some of the problems faeed by that elass of Alsatians who had "half" aceepted the annexation. ... Alsace-Lorraine stories are naturally numerous. Charles de Rouve's Fransoise du Rhin (1915) was crowned by the French Academy in 1916: and Abbé Wetterlé's pretty little story of the first day's of the war, $A u$ Ser $v$. ice de l'Ennemi (1917) is of a sound patriotio inspiration; it breathes contempt for the Gier. man "Kultur" which the Abbé has more right to scorn than any other, having had to endure it so many years as Deputy from Alsace to the Reichstag.

Of the war-time novels whieh endeavor to give an idea of the way in which the people of the rear-the bourgeois class-were affeeted, none probably has seored a greater suecess than Abel Hermant's Heures de Guerre de la Famille Valadier (1915). This is not a great testimonial to such war-time novels. For, were it not that

4 In 1917 he published Le Missionnaire-same style. 369 


\section{FRENCH LITERATURE OF THE GREAT WAR}

the author-by his fecundity more than by his really superior literary gifts-was well known, there are reasons to believe that it would have won him no fame. Hermant writes with humor, he is an Anatole France without genius or philosophical keenness. However, this light vein has made his success, and he therefore exploits it. Now, in war times, the flippant tone is out of place and it would appear inexeusable if one did not understand how diffieult it is for a man of a eertain age to change his style. It is not impossible, however, and even Anatole France, who is much older than Hermant, at least adapted his style to war-circumstances. But Hermant is set in his habits; he is like a cook who would put the same seasoning-let us say pepper-in every dish: soup, meat, ice-cream. He has the mania of introducing wit everywhere; and he would describe in his operetta stylc the sack of Louvain or the sinking of the Lusitania. . . . It is distressing to note that there are all the world over, people who regard this as extraordinarily smart, and so French! Hermant tells of a bourgeois family in Paris during the first, most stirring weeks of the war. They are moderately educated, and especially interested in the stage, the eldest daughter having just received a "premier 
prix de conservatoire." The whole family has more or less melodramatic inclinations, heing good people but Philistines. Against this background he sets up his characters. His observations, which he evidently regards as subtly ironical, are hardly even original. For instance, he notices how in the excitement of war preparations, people overstep all etiquette and talk to each other even though they were not previously acquainted, and this draws from him the eheaply sarcastic remark: "Greatly did it surprise me, for we had been told many times of late, that equality and fraternity were empty words. It did me good to lay aside my skepticism, and to see these pretty fancies revive. . . I I ceased to smile at the 'peuple souverain' ... (p. 20). Those who have a liking for the style goualleur will find it in abundance here. Elsewhere Hermant discusses the appointment of a friend to a position as interpreter; but he reealls that he knows no English: "This is not perhaps an indispensable condition for an appointment " - remarked Madame Valadier (p. 161). The book is full of such insipid remarks. Why did nature give talent to such a man to render the tragedies and beauties of war so absurdly flat? ${ }^{5}$

s Hermant also wrote L'autre Aventure du Joyeux 371 
FRENCH LITERATURE OF THE GREAT WAR

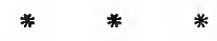

Much more serious and superior in every way is René Boylesve's Tu n'es Plus Rien (1918). The author makes a keen analysis of the redemption of a society woman by the war. The story is parallel to many of those telling of men redeemed by their experience in the army (e.g., Berger's Miracle du Feu). The Odette of Boylesve is by no means a bad woman-that would be too commonplace and easy for him. On the contrary the difficulty with her is that she loves her husband to a point which borders on egotism. Once he is killed, in the very first days of the war, she devotes all her thoughts entirely to his memory, considering any thought not referring to him as nothing less than an infidelity. But she cannot escape the atmosphere of the war, of course; and gradually the enormous sufferings of others all around her bring about the surrender; she yields to a feeling that is even more intensely painful, but is of a loftier nature. The supreme sacrifice she will not make however before another long struggle; but one day she will find it in her to accept the beautiful duty of leading through life a blinded officer, a widower

Garson (1915): an English boy comes to France before the war, and dies there during the war. 


\section{WAR-TIME FICTION}

with two little children, and to found with him a new home.

A short novel of equally fine inspiration is Pierrette, by Antoine Rédier (1917). Rédier is the man who wrote the Mćditations dans la Tranchée, which we have discussed in a former chapter; the novel is worthy of his pen. Pierrette is the fiancée of an officer who has understood, specially since 1914 , the sacredness and sternness of life; she does not like the idea of rearing children. But in spite of that she is morally sound and after a while she comes to see the beauty of the soldier's plilosophy. Her fiancé dies for his country, and she determines to live for her country, and cherish the memory of her dead lover. ${ }^{6}$

$$
\text { * * * } \quad *
$$

Henry Bachelin's La Guerre sur le Hameau (Flammarion, 1917) is as forceful a presentation of some effects of the war upon country people as Hermant's picture of the bourgeois of Paris is trifling. The hamlet of 5 or 6 houses is an out-

${ }^{6}$ Le Mariage de Lison (à l'usage des eombatants et des jeunes filles sans dot), by the same author was published in 1918, and Le Capitaine, in 1919. The latter takes up many ideas already diseussed in Jléditations dans la Tranchée. 
of-the-way place somewhere in France; the dullwitted peasants cannot grasp, it goes without saying, the magnitude and the significance of the struggle,-but war brings about petty jealousies whicl cut deep into the hearts of these simple people; jealousy because the son of one family is not called to arms while the son of another is; then jealousy because the family whose boy did not go does not receive the 25 or 35 sous indemnity from the government; then jealousy because one boy is wounded and the other, who finally had to go to war also, is a prisoner, and again jealousy because when the prisoner returns, the wounded alone gets a compensation . . this is gloomy, but sober and strong realism. Another novel of the rear is M. Level's Vivre pour la Patrie (1917).

$$
\text { * * * * }
$$

Volumes of short stories are abundant. Some are due to the pen of the best known writers. Let us mention Bazin, Récits du Temps de la Guerre: Maeterlinck, Deux Contes (Massacre des Innocents, Orinologie); Greorges d'Esparbès, Ceur de l'An 14 (Yser, Artois, Cliampagne, Argonne, Verdun); Pierre Mille, En Croupe de Bellone, and Sous leur Dictée; L. Frapié, Contes de Guerre; Marcel Boulenger, Sur un Tambour; 
Vallotton, Les Loups; etc. Those tales were for the most part published in periodicals, and later issued in book form.

* * *

- Less truly soldier stories, but still war-time stories, of the romantic kind, are contained in the volumes by some women writers: Colette Yver's llirabelle de Pampelune (1917) is a very exquisite tale-followed by some others-of a woman who marries a soldier when he returns blinded from the war. Camille Mayran 's II istoire de Gotton Connixloo, suivie de L'Oublice, was honored, in 1918, with the Prix du Roman of the French Academy. The authoress Mlle. de Saint-René Taillandier is a grand niece of Taine. * * * *

We ought to say a word about two or three "problem" novels.

Camille Audigier's La Terre qui naît (1917) made a strong appeal to the French publie. It shows the urgent need of cultivating the soil of France after the war-even during the war. The author gives the story of the old farm of Chaturgne, in the Basses-Alpes, dilapidated and almost deserted-which comes to life again, thanks to the energy of young hands (crowned by the Academy). 


\section{FRENCH LITERATURE OF THE GREAT WAR}

Then there are the Bourget novels, dealing, of course, with the revival of Catholicism in France. The first to come out after 1914 was Le Sens de la Mort. In this we read of a famous physician, a skeptic... who knows that his early doom is sealed by cancer. Believing in no future life, he cannot bear the thought of leaving behind him his dearly loved wife, who may perhaps be united to another; and he ventures to suggest that she die with him when his hour comes. She agrees to do so. Then the war breaks out. The doctor is called to treat a young relative of his wife, a soldier, who has been wounded. This man has always loved the doctor's wife, and his patience in suffering, due to his religious faith, touches her. The doctor releases her from her oath, but dies in despair, while the young soldier, who also dies, passes away serenely and in the odor of sanctity, as a good Christian should. The contrast between the two ends wins back the young woman to the Christian faith. In the second, Lazarine (1917), the war is directly the means of regeneration of the hero: a Catholic girl at Toulon loves an officer who is an unbeliever; he is divorced, but his former wife, a perverse woman, comes to claim him; he kills her; surmising a 


\section{WAR-TIME FICTION}

hidden drama, the girl suceceds in preventing the soldier from committing suicide; she eonverts him, and he deliberately seeks death in a perilous expedition at the front. Bourget has done more original and powerful work elsewbere. ${ }^{7}$

It may surprise the reader, but quite a number of novels of a humorous nature have been inspired by the war. A most exquisite story is Foley's Sylvette et son Blessé, entertaining, witty, cheerful. The humorist G. de la Fouchardière published in 1916, L'Araignée du Kaiser (one knows the French phrase "avoir une araignée au plafond"), and in 1917, he published Scipion Pégoulade-a sort of Tartarin of the Great War. Another volume of the same order is Ch. Derenne's Cassinou va-t-en guerre (1918), illustrated. Humorous short stories will be found in Mac Orlan's Les Poissons morts,illustrated by Gus Bofa (1917). Albert Boissière has won success with L'extravagant Teddy

7 The story elieited the usual praise and criticism which other Catholic novels had elicited. It was severely judged by Capitaine Delvert, II istoire d'une Compagnie, mentioned above. This eritieism eoming from a soldier is worth reading (p. 135ff.). His point is that there were as good soldiers, to say the least, among those who simply had "la religion de la Patrie" as among the "croyants" with Bourget's eonnotation of the term. 
de la Croix Rouge Anglaise (1917), and Le Neveu de l'Oncle Sam, which, however, has only a distant connection with the war. Pierre Causse-Mael, writes Jolycoeur, Tommy Canadien (1918). Although not strictly belonging to the "genre"' novel, we may mention André Maurois, Les Silences du Colonel Bramble (1918), describing wittily the English and the French point of view in life; and M. Dekobra's Sammy, volontaire Américain (1918), an amusing picture of the American boy in France.

André Billy's La Malabé is a funny story of a plant that has the power of reviving memories; by means of it the author evokes all the joys of life in time of peace.

Then there is the little book by the famous French lawyer, Ch.-M. Chenu, Totoche, Prisonnier de Guerre-the diary of a German dog which, having taken refuge in the allied lines, becomes the mascot of a tank erew, is wounded, sent to an ambulance in the rear, then to a hospital, and finally he is pensioned and happily marricd. (Colette Yver has a dog story also, Nenette, in her volume, Mirabelle de Pampelune.)

A disconcerting but quite entertaining mixture of realities and fantastic imagination will 
be found in the well known series by Gaston Leroux, Les Aventures extraordinaires de Joseph Rouletabille à la Gucre. Rouletabille is a young Parisian reporter, and also a most elever detective. For instance, in the last volume of the series, Roulctabille chez Krupp (1919), he uneovers in the great Essen ammunition plant a formidable plot by which Paris was simply to be leveled to the ground.

* * * *

Shall we mention some stories with ehildren as heroes? F. Boutet, in Victor et ses Amis (1917), writes of boys doing their bit whenever they ean to help win the war. The books by Machard and by the exquisite draftsman of Gosses et Bonshommes, Poulbot, had a well deserved sueeess; first La Guerre des Mômes and later Le Massacre des Innocents, Légende des Temps de Guerre (a Gotha raid, with three litthe ehildren killed, who meet again in heaven). (Compare with Clandel's Mystery play, La Nuit de Noël 1914, mentioned above.) Add Gisell et Poulbot, Les Gosses dans les Ruines. As to Maehard's Bout de Bibi, Enfant terrible (1918) it is in an entirely different vein . . . (gaulois). 
- 


\section{EPILOGUE}

As early in the war as the winter of 1914 1915, writers began to speculate upon the nature of the after-war literature.

Their prophecies, which at first were very dogmatic, became more and more uncertain as months and years elapsed, until gradually they were discontinued altogether when it became evident how deeply the war had cut into human affairs and how hazardous, therefore, any statement regarding the future must necessarily be. ${ }^{1}$

The cessation of hostilities has thrown no new light upon the subject, so that it is as useless as ever to attempt a description of the spirit of the literature of to-morrow.

1 From the beginning, and so long as they lasted, those prognostics were rather commonplace, even when signed by men of established repute: see Paul Adam, La Littérature et la Guerre (1916); cf. our chapter on "Economie Democratism"; Giraud, Le Niracle Fransais; ef. our referenee at the end of our discussion of Neo-Catholicism; Alfred Mortier's Dramaturgie de Paris (1917), the end of our ehapter on the Stage and the War. A reasonable article by Camille Mauclair, Le Front Littéraire de Demain, in La Scmaine Littéraire (Geneve), October 2nd, 1915. In April, 1919, La Renaissance published a series of letters by eminent authors, on post-war literature. They are as non-relevant as most of the rest. 


\section{FRENCH LITERATURE OF THE GREAT WAR}

The preceding pages, however, bring out a fact that bears upon the problem, and that it might be well to recall: The first short period of high emotional exaltation was followed by a longer period of keen observation of events, and also of intense intellectual tension and activity; that second period was in its turn followed by one of marked decline of interest in the war or in war problems. And this is true of the whole field of literature: War experiences ceased, to a great extent, to inspire poets; war recollcctions ceased to be read so eagerly by the public; and, if some novelists, for conscience' sake, continued to make warriors of their heroes, they laid little stress on their heroic deeds; many novelists, indeed, ignored the war altogether. The same obtained, to even a greater degree, on the stage. ${ }^{2}$

This diminution of interest in war literature, at a time when the prospects of a final victory were increasing, appears to us as a phenomenon of mental fatigue. It is incontestable that in the spring of 1917 and afterwards, the people of France still realized the enormous importance

2 That phenomenon of decreasing interest is most clearly visible when one reads an account of the literary output of war literature year by year, such for instance, as we have given in our articles in the New International Year-Book. 


\section{EPILOGUE}

of the years that they had just lived through, and that they appreciated more than ever the meaning of vietory. Indecd they showed as much determination as ever in the proseeution of the war, bending all their energies to the effort which was to bring about the final triumph. But, after three years of incessant struggle, their strength was diminished, and they had none to give to mere thoughts about the war unless these clearly had a practical bearing on the issue. On the other hand, any cheerful reading which relieved them, in hours of relaxation, from the obsession of the war, was recuperative.

This is all easy to understand. But now, not only does that state of relative exhaustion explain the state of affairs during the last year of the war; it must also be taken into aceount in thinking of the future: for the nerrous strain would not cease all at onee with the signing of the armistice, nor even with the signing of the peace. Indeed, it is likely to be felt more and more for a long period of time. Can we not observe even in the finest writers of the war indisputable signs of that exhaustion? After Gaspard, Benjamin has produced more and more indifferent books; Barbusse has repeated himself after Le Feu, in Clarté; Duhamel himself may 
have rounded up his philosophy as he continued producing war books; after Vie des Martyrs, he did not improve in artistic beauty; Porché, once the vigorous singer of L'Arrêt sur la Marne, ends in the roguishness of Les Butors et la Finette and La Fille aux Joues Roses; and others could be added to the list, Genevoix, Péricard, Massis, etc.

To expect, therefore, either in the realm of literature or in that of philosophy, before a long period of recuperation and restoration of normal conditions, a great constructive inspiration as the result of the stirring up of new ideas by the war, would certainly mean disillusionment.

The history of past wars and their influence upon literature supports that view. The Italian wars, cominenced by Charles VIII of France in 1483 and continued by his successors, were to bring to France the seeds of the French Renaissance and of French Classicism. But that seed did not come to full fruition until nearly two centuries later. Even le Cid is only of 1636, and Andromaque and Tartuffe were not ready till 1667. One may argue that the politico-religious wars complicated matters and retarded the progress of the arts and of literature,-and the contention would be to some extent valid - but 384 


\section{EPILOGUE}

even if one allows a century for contingencies due to that cause, there would still remain another century to be accounted for. Moreover, after the next great erisis, the French Revolution and the Napoleonic wars, internal troubles were not so great as to retard artistic development, and nevertheless France was practically voiceless for a whole generation. Though Chateaubriand and Madame de Staël belong to the period of general struggle, the Romantie movement in literature and in art did not materialize until the suceeding generation. Indeed Chateaubriand himself claimed to the end that he was the supporter of the throne and altar, i.e., of the old order of things, and he never became conscious that his writings had in them the seed of the new order of things. ${ }^{3}$ Lamartine's Médi. tations were still a precoeious produet in 1819 ; and Notre Dame de Paris and Hernani did not appear till 1830: and Alfred de Musset's Confessions d'un Enfant du Sic̀cle is of 1836; moreover, there is question whether we should not consider the whole Romantic Movement as only a transition from Classieism to the really new

3 Even a generation later Balzac's case was a repetition of that of Chateaulriand. Balzac the father of realism was a convinced reactionary in social matters. 
literary era of Realism which begins with Balzac (Comédie Humaine, 1830 sq.), continues through Flaubert (Madame Bovary, 1857), and blooms only with Zola's Rougon-Macquart (1871-92).

It is to such great events as the Renaissance and the French Revolution that the Great War must be compared. It would be absurd to compare it to the Franco-Prussian war which was only an episode in the history of the ambitions of Prussia, and by which the literary evolution was not in the least disturbed. The Naturalist movement had just started with Flaubert and the brothers Goncourt, and Zola continued it as if nothing had happened.

On the other hand, modern progress undoubtedly favors rapid developments. Fifteen centuries elapsed between the beginning of the Christian era and the Renaissance; there were only three centuries between the Renaissance and the French Revolution, and only a century and a quarter elapsed between the Revolution and the Great IVar. It is not unreasonable to believe that science will help us to recover more rapidly from the formidable shock than many seem inclined to believe. It must not be forgot- 


\section{EPILOGUE}

ten either that America remained praetically untouched by the storm, and is destined to play a very important part during the period of reeuperation. Therefore, the lapse of time between the war and the interpretation thereof by poets and thinkers need not be so long as it would have been in the past. Indeed, attempts are actually being made in France to link up directly postwar literature with pre-war literature. This is the case with that group of young French writers who gather about the standard of the Youvelle Revue Française. They have tried bravely to keep alive the spirit that animated them before 1914. It remains to be seen whether the same review-cover will actually "cover" the same philosophical tendencies as at the time when the war interrupted publication."

4 Henri Bachelin believes that it will be possible to take up the work at the point at which it had to be interrupted in 1914. In his suggestive article in La Grande Revue (Sept., 1918), he argues that the France which was destined to eonquer in 1914 is still alive. ... True! but the question is: have the men of France undergone no clange meinwhile? Does not the faet.which is so disconcerting at first sight-that there is a tendency in the novel, in poetry, in philosophy and in the drama, to return to pre-war ideas, merely betray too great a lassitude of mind to permit of the formulating of the new doctrine of to-morrow, rather than a deliberate desire that notling should be changed? Is it not simply a provisional compromise, a "going through the motions" as in the past. until rest has renewed men's 387 
There is another question, closely connected with the preceding, yet differing from it, in that it is more concrete: Has the war inspired any great work of art, any masterpiece comparable to the Iliad, the Roland, les Tragiques, or $L a$ Légende des Siècles? Of course, it has not. The conditions farorable to the production of such works have not yet existed; neither must we expect that masterpiece in the immediate future, nor for some time to come. Indeed, it may never be produced.

The heroes of Troy and of Rome were not sung in a way worthy of them until history had passed into legend. It was only then that the Iliad and the Encid could be written. Charlemagne and his peers had to wait three centuries for the Song of Roland and the Chanson de Guillaume. As for Alexander and Cesar and Joan of Arc, they have never had their Homer, their Virgil or their Turoldus. Even in modern times, when, as we have just pointed out, world affairs may resume their normal course more rapidly, and intellectual, developments follow great crises more closely, Napoleon and his Grand Army did

energy and restored to them the ambition to think? It would be strange indeed,-not to say tragic,-if the Great War was to leave no trace either now or later, on human thought, aspirations, and art. 


\section{EPILOGUE}

not conquer a place in the field of literature until nearly half a century after their victories. Their eelebration was rather a slow and gradual affair. Lui and l'Ode à la Colonne are of 1832; Le Retour de l'Empereur, of 1840 ; Les Châtiments of 1853; and la Légende des Siècles of 1859 and subsequent years. It was more than a century after the young Buonaparte had achieved his first feat of arms at Toulon (179?) that Rostand's L'Aiglon was applauded by the whole world (1900).

What of the Franeo-Prussian war? After a full decade of silence the French began to introduee war into literature, but the heroes of Froesehwiller and Reiehshoffen, of Gravelotte and of Saint-Privat, and the heroes of Sedan-who remind one of the heroes of Roneevaux-eame to their own only in Zola's La Débâcle (1892), and in Une Epoque of the Brothers Margueritte (1897-1902).

The heroes of the Great War, the heroes of the Marne and of the Yser, and those of Yerdun and of the Somme, and of the Second Marne, ean afford to wait. One thing that nobody ean doubt even to-day is that if he does appear, the Bard of the Great War will have ample and glorious material to work upon, better material 
than ever appeared in any world epoch before. The real question is whether a poet can ever arise who is equal to the task. Even Victor Hugo "le grand maître du verbe français" would scarcely have been great enough. ... Meanwhile, we should read again those books which tell of the "héros plus splendides que ceux de Friedland et de Rivoli." 


\section{APPENDIX I}

\section{BIBLIOGRAPII}

The task of giving bibliographical information is much simplified since we can refer to a work of considerable erudition, Jean Vie, La Littérature de Guerre, Mamuel méthodique et critique des publieations de langue française 1914-1918 (Payot). Of course, the work is not exhaustive; a work of that sort can never be; the author has himself indicated some of his omissions. On the other hand the inclusion of the literature from the periodicals-although one can see how often it would be imperative not to exclude it-is a risky thing because the number of titles becomes so enormous; and the author has even oceasionally included translations; some good, like Powell's and Gibbs's volumes of war correspondence, some more questionable, like Graves's suspicious recollections of a spy. The arrangement of the material was a difficult problem: a detailed Table of Contents, and two Indexes (one by names, one by subjects) will however facilitate reference. The method adopted of giving at times short descriptions of the publieations mentioned seems not to have been very consistently followed. But, as they are, these volumes will render invaluable services, and we annot think of trying to duplieate the lists. Let it suffice to say that there are few topics on which the reader eannot find informa391 
tion,give an idea of the variety of material, here are a few titles of chapters, picked out more or less at random: General Histories of the war; Periodical publications of the war; Philosophy of the war and Origin of the war; War and Religion; Catholicism; Protestantism; Confessions of Premeditation by Germans; Military Studies of the war; Spy system; Works on Diplomacy; Belgian Neutrality; Socialism and the war; Accounts of military events,-by outsiders,-by witnesses; Belgium and the war; Trench warfare; Dogs in the war; Devastated France; Joan of Arc and the war; French generals; etc., ete.

Many readers will be glad not to have to choose from this deluge of titles, and for them we offer here a few hints that may prove useful:

They may consult:

A.-In English:

The author's yearly contribution to the New International Year-Book (Dodd, Mead and Co.), article "French Literature," 1914 and ff. Also a special article "The Renewal of French Thought on the Eve of the Great War," in the American Journal of Psychology, June, 1916 (which, however, emphasizes especially a wave of religious inspiration in France before the war).

In the New York Times Book Review of Sunday, Oct. 8, 1916, pp. 338, 411, an article by Jean A. Picard, "War's Influence on French Literature," encumbered with titles, rather indiscriminately selected, 392 


\section{APPENDICES}

not classified, and, of course, stopping at date of publication.

B.-In French :

F. Baldensperger, Littérature d'Avant-Guerre. (Payot, 1919.)

Albert Schinz, "Le Roman Militaire en France de 1870 à 1914, in Publications of the Hodern Language Association of Ameriea, March, 1919.

Jean Vic, op. cit. (especially pp. xviii-xix and pp. 15-16).

Catalogue-Publications de la Cruerre (Paris, Cercle de la Librairie) ; Tome I, 1914-15, Tome II, 1916, etc., each volume has about 160 pages.

Les Livres de la Guerre, Aồt. 191.1-Août. 1916, Préface en vers de $\mathrm{E}$. Rostand. ( 7 Rue de Lille, 1S0 pages.) There one will find much about all kinds of topies; various battles, destroyed cities and cathedrals, spies, aviation, "Kultur," prisoners, ete. To continue this publication, which is now out of print, there were issued a few numbers of Le Livre dont on parle, a selected list which was to appear whenever there was material enough for a new installment. This also was published at Rue de Lille, 7 ; as also, now, the Catalogue Mensuel de la Librairie Française-which is, of course, much more complete. ${ }^{1}$

Many periodicals have published accounts of war books, as they came out. Among them one ought to point out as of special value, the pages published bi-

1 The Bulletin Bibliographique, issued ly the Societé d'Exportation des Editeurs Francais-ahout thirty of the leading publishing firms (13 Rue de Tournon)-for purely advertising purposes, is poorly gotten up. 
monthly by the Mercure de France under the title: "Ouvrages sur la Guerre actuelle."

Finally, let us make room here for the Bulletin des Ecrivains de 1914, 1915, 1916, 1917, 1918, 1919, published by three young writers, R. Bizet, F. Divoire, and G. Picard, and which was sent free to all the writers in the service. Forty-nine issues came out, the last one, in August, 1919, devoted entirely to the authors who died on the field of honor.

With some exceptions, works belonging to Propaganda war-collections have not been mentioned in this volume. But let it be said that some of those booklets are very admirable. Here are the names of some of the best of these collections: Alcan, Publications sur la guerre de 1914-1918; Colin, Etudes et Documents sur la guerre (in this collection came out J. Bédier's well known pamphlet Les Crimes allemands d'après des Témoignages allemands); Berger-Levrault, Librairie Militaire (with two series, Pages d'Histoire and Encyclopédie de la Guerre); Bloud et Gay, Pages actuelles (Catholic); Crès et Cie, Collection Bellum; Perrin et Cie, Pour la Vérité (little volumes of about 50 pages, by members of the "Institute" or Five Academies of France. The first number is by Pierre Lamy, the late Secrétaire perpétuel of the French Academy, L'Institut et la Guerre).

For people who are guided in their choice by the names of publishers, we mention the following firms which can usually be relied upon to issue only works of real value: Alcan, Baillière, Belin, BergerLevrault, Bloud et Gay, Boccard, Calman-Lévy, Chapelot, Charpentier, Champion, Colin, Crès, Delagrave, 


\section{APPENDICES}

Emile-Paul, Fasquelle, Firmin-Didot, Fischbacher, Flammarion, Grasset, Hachette, Larousse, Leclere, Lemerre, Mereure de France, Michel, Nilsson, Nourry, Nouvelle Librairie Nationale, Nouvelle Revue Française, Ollendorff, Payot, Perrin, Plon-Nourrit, Renaissance du Livre, Sansot, Société d'Edition, Société Francaise d'Imprimerie et de Librairie. 


\section{APPENDIX II}

DOCUMENTS REIATIVE TO THE WAR

(Outside of the Domain of Literature, but complementary to it)

Practically all the technical bibliographical indications are omitted, as they can easily be found-if needed-in consulting the work of Jean Vic, La Littérature de la Guerre, already referred to, or, even better, the very convenient annual Tables of the Mémorial de la Librairie Française (Paris, Librairie H. Le Soudier, 174 Boulevard Saint-Germain). For before 1900, see Bibliographie Française, Ire série, 10 volumes; from 1900-1909, 2de série, Tome I, 19001904, Tome II, 1905-1909, etc. These tables contain in one alphabetical series, names of authors, names of titles, and names of topies.

Toutaix, L'Europe et la France de 1871-1914. Gauvals, L'Europe avant la Guerre, 1 vol.Origines de la Guerre Européenne, 1 vol. (Colin).

Roches, Manuel des Origines de la Guerre (Bossard).

Histoire de la Guerre par le Bulletin des Armées de la République (Hacliette).

Les Communiqués officiels depuis la Déclaration de la Guerre (Berger-Levrault). 
Notre Epopée, Récits officiels de Combattants (Soc.

Française d'Imprimerie et de Librairie).

La Guerre, Documents de la Section photographique (Colin).

Général Malleterre, Etudes et Impressions de Guerre. En série, avec Cartes et Tableaux. 5 vol.

Joseph Reinach, La Guerre de 1914-1918, et les Commentaires de Polybe. 17 series.

GÉnéRal Balat, La Grande Guerre sur le Front occidental. 3 vol. out.

Général Berthaut, Les grandes Batailles de la Guerre de la Marne à la Mer du Nord. Vue d'ensemble sur les opérations militaires de $1914-1918$.

L. Brossoletrte, Histoire de la Grande Guerre. 20 Cartes, un tableau synchronique et un index ( 1 volume).

Victor Giraud, Histoire de la Grande Guerre. 5 fascicules.

P. Crokaert, L'immortelle Mêlée, Essai sur l'Épopée militaire belge.

Pierre Dauzat, Guerre de 1914. De Liège à la Marne. (Avee Croquis et Cartes.)

On the first Battle of the Marne, see Vic, op. cit. Also, G. Babin, La Bataille de la Marne, 6-12 sept. 1914. Esquisse d'un Tableau d'ensemble. Gervais-Courtellenont, La Bataille de l'Ourcq. LE Gorfic, Les Marais de Saint-Gond, Histoire de l'armée Foch à la Bataille de la Miarne. 398 


\section{APPENDICES}

On the Battle of the Yser, see Vie, op. cit. The best known accounts are:

L. Madelin, La Mêlée des Flandres. L'Yser el Ipres (avee 3 eartes).

Le Goffic, Dixmude. I'n ehapitre de l'Iristoire des Fusiliers marins, 7 oct. au 10 nov. 1911.Steenstraete, $\ln 2^{\circ}$ chapitre-St. Georges et Nieuport, suite et fin.

G. LE Barl, La Brigade des Jean Gouin. IIistoire documentie et anedotique des fusiliers marins de Dixmude d'après des doeuments originaux et des récits de eombatlants.

Comid Willy Breton, Les Combats de Steenstraat (avril-mai 1915); une page glorieuse de la résistance belge.

L. Bocquart et E. Hostex, Un Fragment de l'Epopée S'énégalaise. Les Tirailleurs noirs de l'Yser.

On the Battle of Verdun: See Vie, op. cit.

Henri Dugard, La Victoire de Verdun (26 fév. 1916-13, nov. 1917).

JoLLIVET, L'Épopée de Verdun.

H. Bordeaux, Les demiers Jours du Fort de Taux. -Les C'aptifs délirrés.

For other battles see Vie, op. cit., and general works mentioned above; e. g., Gén. Malleterre's Etudes et Impressions, volume V. La Bataille de Libération et de Victoire; Jean de Pierrefeu, La Seconde Bataille de la Marne; ete. 


\section{FRENCH LITERATURE OF THE GREAT WAR}

Military life :

Marcel Prevost, D'un Poste de Commandement (La façon de préparer une bataille-L'Ailette).

F. DE Tessan, Quand on se bat. (Episodes to illustrate the various services: La bataille; agents de liaison; mitrailleuses; grenadiers; pionniers et sapeurs; crapouillots; avions; automobiles; etc.)

Capitaine Danrit, La Guerre souterraine (Mining and sapping).

Anonymous, La Vie des Tranchées (Berger-Levrault) (Building of trenches, life in trenches). Daniel Mornet, Tranchées de Verdun (BergerLevrault).

See also Vic, op. cit., p. 180, 253-5.

JOSEPH BÉdIER, L'Infanterie.

Fr. Marbre, Notre Artillerie.

Lieutenant Lestringuez, Les Chars d'Assaut

Français pendant la Guerre.

Capitaine Langevin, Les Cavaliers de France.

Raymond Lestonnat, L'A.B.C. de la Guerre navale.

Amiral Degour, Guerre Navale et Offensive.

Commandant Vedel, Nos Marins à la Guerre, sur

Mer et sur Terre.-Sur nos Fronts de Mer. Croviezier, Les Guerres aériennes. Le Rôle de la Cinquième Arme.

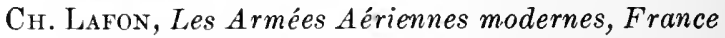
et Etranger.

"La Cigogne" (J. Duval), L'Armée de l'Air.

P. Bonnefon, Le Premier As, Pégoud. 


\section{APPENDICES}

H. Bordeaux, Le Chevalier de l'Air, Georges Guynemer.

M. NADACD, Guynemer.

Viallet et Mortane, Quelques grands Duels aériens.

For the Psychology of the soldier, see Vie, op. cit. pp. 251-2. Also indications in Part I, chap, II, of this book, and the following works:

Capitaine Z - L'Armée de la Guerre.-L'Armée de 1917.-L'Officier et le Soldat Français.Vertus guerrières.

E. Meyer, Autour de la Guerre. Essais de Psychologie militaire.

Dr. L. Heot et Dr. P. Volvenel, Le Courage.-Le Cafard.-Psychologie du Soldat.

G. Duxas, Troubles mentaux et Troubles nerveux de Guerre.

Several books on military terms:

Axonymocs, Dictionnaire des Termes militaires et de'l'Argot des Poilus (publ. by Larousse).

Anonrarous, Le Français tel que le parlent nos Tirailleurs Sénégalais (mentioned in Catal. mensuel de libr. fr. Juillet, 1917).

A. Dauzat, L'Argot de la Guerre d'après une Enquête auprès des Officiers et Soldats.

F. Dechelette, L'Argot des Poilus. Dictionnaire humoristique et philosophique du Langage des Soldats de la Grande Guerre de 1911.

G. Esnault, Le Poilu tel qu'il se parle. Dictionnaire des Ternes populaires récents et neufs 401 


\section{FRENCH LITERATURE OF THE GREAT WAR}

employés aux Armées en 1914-1918, étudiés dans leur Etymologie, leur Développement et leur Usage.

L. Sainéan, L'Argot des Tranchées d'après les lettres des Poilus et les Journaux du Front. (This author has since published several complementary articles in the Mercure de France.)

In Franconi, Un Tel de l'Armée Française (1918), see Chapter on Exégèse de certaines Phrases militaires.

In M. Nadaud, En plein Vol, there is in an Appendix, a catalogue of familiar terms used by French aviators.

See also various articles in L'Intermédiaire des Chercheurs.

On linguistic problems in connection with the war see Ch. Meillet, Les Langues de l'Europe nouvelle (1918).

On the question of making "Esperanto" or "Ido" the International langmage, or the question of adopting the "Projet Chapelier" (to make French and English the two International languages), see New International Year-Book, New York, 1915 and ff., articles "International Language."

Paul Souciion, Les Mots de la Guerre (like "On les aura," "Ils ne passeront pas," "Debout les Morts," etc., in 3 parts.

A. MARY, Maximes des Grands Capitaines Français. Trogan, Les Mots historiques du Pays de France.

Newspapers at the Front, and in Prisoners' camps: 402 
One can find a list of them up to 1916 in Publications sur la Guerre (see Appendix I). Then an article in the Grande Rerue, Dée., 1916, by J. Bompart, and in the N. Y. Century Hagazine. Sept., 1916, by Gelett Burgess. One may consult also Tous les Journaux du Front, Prélace par P. Albin,-many fac-similes. Then the reproduction by Larmandie, of Les Cent Numéros du Petit F'rançais-fae-simile edition of a paper published in a prisoners' eamp in Germany.

Special mention must be made of La Libre Belgique, fondée le 1 février, 1915, régulièrement irrégulier, which the editors succeeded in publishing right in invaded Belgium. The story of this newspaper epie has been told repeatedly in various papers and periodicals; and in the two volumes: P. Goemaere, Histoire de la Libre Belgique clandestine (Bruxelles, $1919)$; Fidelis, Histoire merceilleuse de La Libre Belgique (1919). See also Marcel, Mes Aventures et le Mystère de La Libre Belgique, and Jean Massart, La Presse clandestine en Belgique.

Dr. Lucien Graux, Les fausses Nouvelles de la Grande Guerre (3 volumes out).

Albert Pingaud, La Guerre vue par les Combattants Allemands (1918).

For Cartoons see: L'Esprit Fransais, Les Caricaturistes, and L'Esprit satirique en France, Préface d'A. Alexandre, two anthologies of the best French war-caricatures (Berger-Ievrault). John GrandCarteret, Caricatures et Images de la Guerre, selected and commented upon by the well known artist, Vol. I. Kaiser, Kronprinz et Cie, II. La Kultur et ses Hauts- 


\section{FRENCH LITERATURE OF THE GREAT WAR}

faits. Also a special album on Verdun, Images de Guerre, Pièces historiques, Estampes, Curiosités, 350 images et caricatures françazises, allemandes, neutres et ennemies (12 Planches hors texte, 1917).

A remarkable volume is that by Sem, Un Pékin sur le Front, with both text and 150 illustrations. (In this volume is found the famous account of the horrors of Gerbéviller, by Soeur Julie.)

Poulbot's exquisitely pathetic drawings of children during the war are known to all: Des Gosses et des Bonshommes, Les Gosses dans les Ruines, Le Massacre des Innocents, etc. So are Hansi's Mon Village; Histoire d'Alsace; Paradis Tricolore. 


\section{APPENDIX III}

CATALOGUE, IN ALPIIABETICAL ORDER, OF SOME

OF THE BEST WAR DLARIES AND RECOLLECTIOAS

(Many have been mentioned in this book, see Index.)

Allier, R., In Memoriam (chiefly letter's witten by him and printed by the family after the young man's death).

Axoxrmous, Lettres d'un Soldat. (Préface by

Chevrillon.) (Killed in action.)

Axonysious, Un Soldat de France. Lettres d'un

Médecin auxiliaire, 31 juillet-11 avril, 1917.

(Préface by E. Boutroux.)

Aubry, L'abbé, Ma Captivité en Allemagne.

Belinont (Capitaine), Lettres diun Officier de

Chasseurs Alpins, 2 août, 1914-2s déc. 1915.

(Killed in action.)

Benjaurn, R., Sous le Ciel de France.

Bertrand, Lieut., Victoire de Lorraine. Carnei d'un Officier de Dragons-Carnet de Route d'un Officier d'Alpins.

Blanchet, E. L., En Représailles.

Bocquet, L., eт Hosten, E., Cnn Fragment de

l'Epopée Sénégalaise. Les Tirailleurs de l'Yser. Boucheron, G., L'Assaut. L'Argonne et Tauquois avee la 10me Division, 1911-1915.

Boubon, V., Avec Charles Péguy, de la Lorraine à 405 
la Marne. (A moving account of the last days of the famous writer, killed in action on the first day of the Battle of the Marne.)

Boulenger, J., En Escadrille.

Bourguet, Lieut.-Col., L'Aube sanglante. De la Boiselle (Oct. 1914) à Tahure (Sept. 1915). (Killed in action.)

Bréant, Commandant, De l'Alsace à la Somme. Souvenirs du Front (août 1914-janv. 1917).

Breton, Commandant Willy, Un Régiment Belge en Campagne. Les Fastes du $2^{\circ}$ Chasseurs-àpied, août 1911-Janv. 1915.

Buteau, Max, Tenir. Récits de la Vie de Tranchée. Cabanel Aumônier, P. C., Avec les Diables Bleus. I, Artois, II. Taux.

Carnets de Route de Combattants allemands. (Un Officier Saxon; un Sous-Officier Posnanien; un Réserviste Saxon, publiés par J. de Dampierre, Archiviste-paléographe.)

Chevoleau, L'Abbé, Caporal (ambulancier) au 90 me d'Infanterie, by Emile Bauman. (The book is made up chiefly of letters from the priest who died in action.)

Christian-Frogé, R., Morhange et les Marsouins en Lorraine. "Marsouin" is the familiar name giveu to soldiers of Colonial Infantry.) - Les Captifs. (Well known.)

Darstein, Général F. de, La $56^{\circ}$ Division au Feu. Delacommune, Ch., L'Escadrille des Éperviers. Impressions vécues de Guerre aérienne.

Delejer, A., Pélerin mutilé, Blessé de Vauquois 406 


\section{APPENDICES}

(1918). (One of the rery few in which the author gives expression completely to his despairing soul.)

Delvert, Capitaine, Ilistoire d'une Compagnie (Main de Massiges, Champagne, Verdun). -Quelques Hiéros. Récits authentiques de la Grande Guerre.

Descubes, B., Mon Carnet d'Eelaireur.

DiDE, M., Ceux qui combattent et ceux qui meurent. Dieterlen, M., Le Bois Le Prêtre.

Dolle, A., La Cote 304 (Verdun). Accompagné de Souvenirs d'un Officier de Zouaves.

Dubarle, Capt. Robert, Lettres de Guerre. (Killed in action.)

Dubrulle, Carnet de Route.

Dufour, J. J., Dans les Camps de Représailles.

Duhamel, G, Tie des Martyrs.-Civilisation-La

Possession du Monde.

Dunan, M., Eté Bulgare. 'Juillet 1915-oet. 1915.

Dupont, M., En Campagne, 1914-1915. Impres-

sions d'un Officier de Légère,-MIobilisation,

Great Retreat, Marne, Descent of the horsemen into the trenches, Champagne and Artois. Awarded the Prix Bodin, by the Academy. -L'Attente (Continuation) - "attente" of victory.-Victoire is the $3 \mathrm{~d}$ rol.

Duval-Arxould, V., Crapouillots. Feuilles d'un Carnet de Guerre.

Erlande, A., En Campagne avec la Légion Etrangère.

D'Estre, II., D'Oran à Arras. Impressions d'un 407 


\section{FRENCH LITERATURE OF THE GREAT WAR}

Officier d'Afrique, 24 juil. 1914-18 janv. 1915. EтÉvÉ, M., Lettres d'un Combattant. Août 1914juil. 1916. (Killed in action.)

Fierre, JaCques, 80,000 Milles en Torpilleur. Flers, Robert de, Sur les Chemins de la Guerre. Foley, Ch., La Vie de Guerre 1914-1915, contée par les Soldats. Lettres recueillies et publiées.

Fonsagrive, Lieut., En Batterie. Verdun, La Somme, Aisne, Verdun.

Franconi, Un Tel de l'Armée Française (Killed). Frégeolière, Renard de la, pilote militaire, $A$ Tire d'Ailes, Carnet d'un Aviateur et Souvenirs d'un Prisonnier.

Fribourg, André, Croire. Histoire d'un Soldat. GaIllet, LÉon, sous-lieut. d'Infanterie Coloniale, Coulibaly. Les Sénégalais sur la Terre de France. Portraits, Anecdotes, Souvenirs.

Genevorx, M., Sous Verdun, août-oct. 1914.-Nuits de Guerre (a continuation of the preceding) Au Seuil des Guitounes.

Gentil, R., La Flamme Victorieuse.

Ginistr, P., et Gagneur (Capt. M.), Histoire de la Guerre par les Combattants (published by series).

Giraudoux, J., Lectures pour une Ombre.

Grandmaison, Impressions de Guerre de Prêtres Soldats (2 series). Two well known chapters: "Dans la Fournaise de Verdun," "Deux Marsouins."- "marsouin" is the familiar name given to soldiers of Colonial Infantry. 408 


\section{APPENDICES}

Grasset, Commandant, Fingt Jours de Guerre aux Temps héroiques (the first 20 days).

Hassler, Capitane, Ma Campagne au jour le jour, août 1911-Dec. 1915.

Hémard, J., Chez les Fritz. Notes et Croquis de c'aptivité.

Henches, Commandant, A l'Ecole de la Guerre. (Killed in action.)

Hennebors, Cir., Aux Mains de L'Allemagne. Journal d'un Grand Blessé.

Henriot, E., Carnet d'un Dragon dans les Tranchées, 1915-1916.

Herscher, Lieut. E., Quelques Images de la Giuerre.

Hourtico, L., Récits et Réflexions d'un Combattant. Aisne, Champagne, Verdun.

Joubaire, Alf, Pour la France. Carnet de Route d'un Fantassin.

Jubert, R., Verdun (Mars-avril-mai 1916), Préface by P. Bourget. (One of the best. Author killed in action.)

Julia, Dr. F. E., Mort du Soldat. (One of the best known.)

Juxod, Ed., Capitaine à la Légion Etrangère, Lettres et Souvenirs. (Killed in action.)

Kadoré, Pierre De, Mon Groupe d'Auto-canons. Souvenirs d'un Officier de Marine, Sept. 191.4Avr. 1916 (tells of Ypres).

LA BRUỲ̀re, René, Deux Années de Guerre navale.

LA Crolx, En Plein Ciel.

LAFond, G., Ma Mitrailleuse. Avec les Mitrailleurs de la Coloniale. 


\section{FRENCH LITERATURE OF THE GREAT WAR}

Lafont, R., Au Ciel de Verdun.

Lauzanne, (Stéphane), Feuilles de Route d'un Mobilisé.

Laurentin, Le Sang de France.

LÉAUd, (Alexis), Spectacles de Guerre.

Le Ball, G., La Brigade des Jean Gouin. Histoire documentaire et anecdotique des Fusiliers Marins de Dixmude; d'après des Documents et Récits de Combattants.

Leleux, Ch., Feuilles de Route d'un Ambulancier. (LemerRe.) Les As peints par eux-mêmes. LÉRY, JEAN, Bataille de la Forêt de l'Argonne, 1915. Impressions d'un Témoin (very often quoted).

LÉtard, E., Trois Mois au Premier Corps de Cavalerie. De Senlis à Liège; de Liège à Paris; de Paris à Y Y pres.

Liberdan, H., Ce qu'a vu un Officier de Chasseurs à pied 2 août-28 sept. 1914.

Lieut. E. R. (Capitaine Tuffrau), Carnet d'un Combattant (well known).

Lintier, P., Ma Pièce. Avec une Batterie de 75.Le Tube 1233 (posthumous).

Madelan, L., Les Heures Merveilleuses d'Alsace et de Lorraine. Mémoires et Récits de Guerre (1919).

Malherbe, H., La Flamme au Poing.

Mallet, Christophe, Étapes et Combats. Souvenirs d'un Cavalier devenu Fantassin.

Marc, Lieut., Notes d'un Pilote disparu, 1916-1917. Merlant, Joachim, Souvenirs des Premiers Temps de Guerre. (Died of wounds.) 


\section{APPENDICES}

Milan, René, Vagabonds de la Gloire. I. Campagnes d'un Croiseur, II. Trois Étapes, III. Matelots aériens.

Miluet, F., En Liaison avec les Anglais. wouvenirs de Campagne.

Morane, Jacques, Chasseur de Boches. (Aviation.) NaDaUd, M., En plein Vol.

Niox, LÉon, Mes Six Evasions.

Ollivier, Capitaine, Onze Mois de Captivité dans les Hôpitaux allemands.

Ouy-Vernazobos, Cir., Journal d'un Officier de Cavalerie.

Parèze, D., Et nous . . les Marins.

Paulhan, Jean, Le Guerrier appliqué. (Story of an "Intellectuel" who tries to adapt himself to military life.)

PÉRICARD, J., Face à Face, Souvenirs et Impressions d'un Soldat de la Grande Guerre.-Ceux de Verdun.-Debout les Morts!

PÉzard, A., Nous autres à Vauquois, 1915-1916.

Pinguet, J., Trois Etapes de la Brigade des Fusiliers Marins.

Pirenne, Jacqles, Les Vainqueurs de l'Yser. Préface par Verhaeren et Vandervelde.

Prevost, Marcel, D'un Poste de Commandement (Bataille de l'Ailette).

Prieur, Cir., De Dixmude à Nieuport. Journal de Campagne d'un Oficier de Fusiliers Marins, Oct. 1914-mai 1915.

Raynal, Commandant, Journal du Fort de Vaux. RÉdier, Antr., Méditations dans la Tranchée. 


\section{FRENCH LITERATURE OF THE GREAT WAR}

Renaud, Jean, La Tranchée Rouge. Feuilles de Route, sept. 1914-mars 1916.

RENÉ, H., Lorette une Bataille de 12 Mois; oct. 1914 -oct. 1915.-Jours de Gloire, Jours de Misère. Histoire d'un Bataillon (Alsace, Lorraine, Marne, Ypres, Artois, Verdun) 1914-1916.

Riou, Gaston, Journal d'un Simple Soldat, Guerre, Captivité, 1914-1915.

RIvière, J., L'Allemand. Souvenirs et Réflexions d'un Prisonnier de Guerre.

RoBIdet, E., Croquis de Guerre. RouJon, JaCQues, Carnet de Route. DE Tessan, F., De Verdun au Rhin. Ruffin, Baron C., La Belgique héroïque et vaillante. Récits de Combattants recueillis par.

Souvenirs de Guerre d'un Sous-Officier allemand, 1911-1915. Traduction publiée avec Préface de L. P. Alaux (Alcan 1918).

Thierry, A., Carnets de Guerre. (End is the diary of a prisoner.)

Thomas, Louis, Les Diables Bleus pendant la Guerre de Délivrance, 1914-1916.-Avec les Chasseurs.

Tudesq, A., Les Compagnons de l'Aventure. (Navy.)

VARIOT, JEAN, La Croix de Caumes. Documents sur les Combattants du Bois Le Prêtre.

VAssal, J., Dardanelles, Serbie, Salonique, Impressions et Souvenirs de Guerre, avril 1915fév. 1916.

Veaux, Dr. G., En suivant nos Soldats de l'Ouest. 412 


\section{APPENDICES}

Charleroi, Guise, La Marne, Reims, Craonne, Arras, l'Yser.

Vignaud, J., Les Sauveurs du Monde. ("Contes suggérés par d'horribles visions.")

Warnod, A., Prisomier de Guerre. Notes et croquis rapportés d'Allemagne.

Wilde, Robert DE, Mon Journal de Campagne,

Liège et l'Yser.

Z . ., Capitaine, L'Armée de la Guerre.-L'Armée de 1917.-Vertus Guerrières.

Zavie, EMILe, Prisonnier en Allemagne. 


\section{INDEX}

(Names of authors and books mentioned only in the three Appendices are not given here.)

Abbé Constantin, 361. Abensour, 22S.

Achard Amedee, 185.

Action française, $236 \mathrm{f}$., $256,274$.

Adalbert J., 22 S.

Adam Juliette, 7 .

Adam Paul, 8, 275, 379. Adjutant Benoit, $364 \mathrm{f}$.

Agadir, 110.

Agathon (Tarde et Massis), 253.

Agir, $2 \mathrm{S1}$.

Aicard J., 7, 31, 299, 329.

Aiglon L', 304, 359.

Ailes rouges de la Guerre

Les, $295 \mathrm{ff}$.

Alcohol, 289 f, 343.

Alexandre A., 3:9.

Allan M., 348.

Allemagne, 9.

Allemagne en France L',

238.

Allemand L', $213 \mathrm{ff}, 254$.

Allemand d' Amérique, 366.
Allier R., 96.

Alphand, 217 .

Alsace, 9, 35, 46, 107,

$173,193,200,278,300$,

$342,349,364,369,404$.

Altiar El., 216.

Amazone L', 356.

Ambulance, 140, 204.

Ame des Chefs $L, 33$.

Ame du Soldat L', $96 \mathrm{ff}$, $255,276$.

Ame française et la Guerre L', 11.

America, 20, 91, 99, 196, 28s, 378.

Ami Fritz L', 343.

Amica America, 107 .

Anarchy, 260.

André Rieu, 33.

Anges gardiens Les, 364 .

Anti-militarism, 16.

Anvers, 161.

A pollinaire G., 329.

Appel des Armes $L^{\prime}, 70$, 95.

Appel du Sol L', 42, 93, $100,115$. 


\section{INDEX}

Appel du Soldat L', Bachelin H., 373 f, 387. $233 \mathrm{f}$ :

Après Guerre L', 238. Araignée du Kaiser L', 377.

Archevêque et son Fils, L', 361 .

Ardennes, 190.

Argonne, 31, 110.

Arguilbert M., 228.

Ariel et Caliban, 156-7.

Armistice, 200, 201.

Arnoux A., 61.

Arras, 170, 193.

Arrêt sur la Marne L', $317 \mathrm{ff}$.

Artois, 12, 125.

Assassin Innombrable L', 295.

Assomoir L', 343.

Atrocities, 8, 84, 196, 342, 355.

Aubry Abbé, 203.

Audessus de la Mêlée, $19 \mathrm{ff}, 97,276$.

Audigier C., 375.

Aulard A., 254.

Autre Combat $L$ ', 357.

Auxiliaires, 56, 59.

Avant-Guerre L', 236,

366.

Avenir Notre, 282.

Avèze, 366.

Badigeon, aviateur, 55.

Baldensperger F., 12.

Ballades françaises, 313 ff.

Balzac, 63, $385 \mathrm{f}$.

Baratier, 69.

Barbarians, 5 f., 8, 9, 84, 156-7, 187, 189, 193 ff., $208 \mathrm{f}, \quad 212-15, \quad 258$, 261, 340, 347 .

Barbusse H., 24, 33 ff., 48, 59, 124 f., 177, 180, $221,333,383$.

Barrès M. (see Nationalism), 11, 12, 233, 256, 303, 321, 342, 364. Basly Em., 193 ff. Bataille H., $301 \mathrm{ff} ., 356$. Baud-Bovy, 216.

Baulu Marguerite, 161. Bazin R., 364, 374.

Beethoven, 332.

Belgique La Libre, 403. Belgium, 5, 9, $160 \mathrm{ff}$., $173,200,204,250,258$, 285, 296, 347, 392.

Bellouard J., 321 ff.

Belphégor, 248.

Benda J., 21, 98, 245 ff., 261.

Benjamin R., 30 ff., 59 ff., 383.

Aviation, 55, 61, 84, $203 . \quad$ Benoît M., 228. Aviators, 53, 176.

Berger Cyril, 368. 


\section{INDEX}

Berger Marcel, 44, 50, 56 Boudon V., 236.

ff., 372 .

Bergson H., 8, $243 \mathrm{ff.}$, 263.

Bernard T., 227.

Bernardi, 245, 252.

Bernhardt Saralı, 348.

Bernstein H:, 345 .

Bertrand A., 42 ff., 93, $100 \mathrm{ff}$.

Beulemans à Marseilles, 340,360 .

Billaud J., 351.

Billotey, 353.

Billy A., 37s.

Binet-Valmer, 25, $177 \mathrm{ff}$.

Bisbur au Democratic Palace, 176.

Bismarck, 232-3, 312.

Blanche J., $218 \mathrm{ff}$.

Blanchet E. L., 212-13.

Blessé Journal d'un Granid, 140, 207 f.

Blue Devils. (See Diables bleus.)

Boche, 97, 101, 155, 304.

Bois H., 254.

Boissière A., 377.

Bonnet G., 96 ff., 173, 276.

Bordeaux H., 61, 153.

Bormier H., 342.

Bose P., 202.

Bossuet, 258, 266.

Batrel Th., 336.
Boue sous le Ciel De la, 329.

Boulangism, $233 \mathrm{f}$.

Boulenger M., 2.2.2, 374.

Bourcier M., 190.

Bourget P., 25, 154, 249. $256,274,376 \mathrm{f}$.

Bourgmestre de Stilemonde Le, $341 \mathrm{f}$.

Bourru, Soldat de Tauquois, 31, 50, 77, 176. Bout de Bibi, 379.

Boutet F., 379.

Boutroux E., 242, 24i, 262.

Boyer d'Agen, 329.

Boylesve R., 372.

Briand $\mathrm{Ch}, 50$.

Brisson, 339, 361.

Pritish, 59 ff., 67, 196, 288, 378.

Broyer L., 318.

Bruneau L., 238.

Brunetière F., 249, 256, 258.

Brunot F., 34?.

Buteau M., $157 \mathrm{ff}$.

Butors et la Finette Les, $317,349 \mathrm{ff}$.

Cabaret Le, 61.

Cafard, 122.

Cahiers de la Quizaine, 13, 235, 245. 


\section{INDEX}

Cahiers d'un Artiste, 218 ff.

Calligrammes, 329.

Capricieuse La Grande, 367.

Cambon V., 282.

Candide, $101 \mathrm{ff}$.

Canonge Gén., 8.

Capitaine Le, 91, 373.

Captives. See Prisoners.

Cartoons, 403-4.

Cassinou va-t-en Guerre, 377.

Cathédrales Les, 348.

Catherine de Russia, 250.

Catholicism, 25, 92, 93, 96,323 f., 376 f., 392.

Causse-Mael, 378 .

Célarié Henriette, 192, 202.

Cent Visions de Guerre, 325.

Ceux de l'An 14, 374.

Ceux de la Nuque, 221.

Ceux de Verdun, 13.

Chacun son Devoir, 367. Chagrin sous les vieux Toits, 225.

Chalk-Pits, 170.

Champagne, 154.

Champenois J., 329.

Chamsaur F., 295.

Chansons, 336.

Chansons de Guerre, 336. Chansons de Route, 336.
Chansons pour les Poilus, 329.

Chant dans la Tourmente, 303.

Chant de Haine, 295.

Chant 'du Renouveau, 303.

Chantecler, 304, 354.

Chants du Bivouac, 336.

Chants de Consolation, $321 \mathrm{f}$.

Chants du Soldat, 293, 336.

Charles E., 337, 352.

Charlotte en Guerre, 222.

Chateaubriand, 236, 385.

Chaureau L., 122, 140.

Chemin des Dames, 181.

Chenu Ch. de, 378.

Chéradame A., 238.

Chevrillon A., 78, 79.

Chevoleau L' Abbé, 96.

Chignole, 53.

Christian-Frogé R., 203.

Chuquet A., 200.

Church (see also Pope), 12, 92, 237, 261, 274. Cing Prières pour Temps de Guerre, 323. Civilians, $190 \mathrm{ff}$.

Civilization, 8, 18, 64, $138 \mathrm{f} ., 275$.

Clarté, 40.

Claudel P., 254, 265, 315 ff., 346,379 . 


\section{INDEX}

Clavel Soldat, 49.

Clémenceau, $37,282 \mathrm{ff}$.

Croupe de Bellone En, 374.

Closerie de Champdolent La, 364.

Coignard, 101.

Colette Baudoche, 342, 364.

Colombelle Mme., 193.

Combarieu J., 229.

Commentaires de Polybe, 398.

Cruelty (see also terrorization and similar words).

Cruelty of German women, 196- $\overline{7}, 211$, 216.

Crnicism, 34 .

Cyrano de Bergerac, 224, 304.

Commentaires sur la Cyrano aux Tranchées, Guerre des Boches, $35+\mathrm{f}$.

13.

Comte A., 246, 271.

Contes (See short stories), 61 .

Contes de Guerre, 374.

Coppée Fr., 256.

Corneille, 342, 384.

Cornet, 69 .

Courage, 122.

Couronne Douleureuse $L a, 307 \mathrm{ff}$.

Courteline, 227 .

Coutras P., 59.

Couvreur A., 356.

Cran Le, 223-5.

Créer, 282.

Critias Sentiments de, 21, $245 \mathrm{ff}, 261$.

Croire, Histoire d'un Soldat, $107 \mathrm{ff}$.

Croisset Fr. de, $35 \pi$.

Croix de Bois, $36 \mathrm{~s}$.

Danrit, 33.

Darboise Jean, 56 ff.

Darwinian Theory, 2 76 f., 280.

Daudet A., 115, 189.

Dandet E., 207.

Daudet L., 236 f., 366.

Debâcle La, 1S

Debout les Morts, 147 .

Débris de la Guerre, 910.

Défense de Schirmect, 349 .

Dekobra M., 378.

Delamarre, 357.

Delarue-Madrus Mme., 302.

Delemer A., 121.

Delvert, 44, 153 ff., 159, $37 \pi$ 


\section{INDEX}

Démocratie Nouvelle Vers la, $287 \mathrm{ff}$.

Democratism, 256, $269 \mathrm{ff}$.

Derenne Ch., 377.

Dérieux H., 254, $330 \mathrm{ff.}$

Denis Jean,

Derniers Jours du Fort de Vaux, 153.

Déroulède Paul, 293, 329 ff.

Derrière la Bataille, 122123.

Désastre Le, 187, 364.

Deseartes, 65, 245, 266.

Destruction, 19S, 302, 392. (See Barbarian and similar words.)

Diables Bleus Les, 140, 141, 176.

Diables Bleus pendant la Guerre de Délivrance, $141 \mathrm{ff}$.

Diderot, 101, 250.

Discipline, $90 \mathrm{ff}$.

Divine Trágédie La, 301 ff.

Dixmude, $160 \mathrm{f}$.

Donnay M., 227, 345.

Dorgelès R., 368.

Douaumont, 150, 188.

Douleurs qui espèrent, 140.

Dragon Carnet d'un, 159. Dramaturgie de Paris, $361,381$.
Dreyfus-Affair, $\quad 233$ f., 237.

Droulers A., 201.

Dubarle Capt., 147.

Ducray R., 284.

Dufour J. J.,

Duhamel G., 90, 121, 123 ff., $383 \mathrm{f}$.

Dumas André, 348.

Dumas Dr. G., 123.

Du Tartre, 216.

Ecole de la Guerre A l', $22,84 \mathrm{ff}$.

Ecole des Indifférents $L^{\prime}$, 103.

Ecoutes de la France qui vient Aux, 204.

Elération, 345.

Elkenfelder Maj., 35.

Embusqué L', 366.

Emperor, see Kaiser.

"Enfants du Crime," 340. Enfant du Mort L', 356. Energie féminine penddant la Guerre, 228.

Energie nationale Roman de l', 233, $256 \mathrm{f}$. Enfer $L$, 3S, 39. Engagé Volontaire Mémoires d'un, $177 \mathrm{ff}$. Epis Rouges Les, 351. Epoque L', 364, 389. Erekman-Chatrian, 343. Erlande, $162 \mathrm{ff}$. 


\section{INDEX}

Esparbès G. de, 374.

Etanger Capt. see Nolly, 70 .

Eternelle Présence $L^{\prime}$, 348.

Etévé M., $94 \mathrm{f}$.

Evasion, Récit de Deux

Prisonniers, 216.

Evasions Les Belles, 216.

Evasions Mes six, 216.

Extravagant Teddy, 377.

Fallet, C., 216.

Familles spirituelles de la France, 12.

Farrère $\mathrm{Cl} ., 61,35 \mathrm{~S}$.

Faust, 101.

Femme Française et son activité, 228.

Femmes pendant la Guerre, 228-9.

Fénelon, 232.

Ferry J., 272.

Feu Le, 24, 33 ff., 42, 50, 54, 59, 77, 107, 115, 124 f., 333, 363,' 368.

Fiancés de 1914, 368.

Fichte, 262.

Fiction, see Novel.

Fielle P., 123.

Fierre J., 15S, 181.

Fifre de Bertrandoux Le, 329.

Fille de Roland La, 342 .
Flambeau Gavroche et, 305.

Fkumbée La, 338, 343.

Flamme au Poing La, 115

fï., 138.

Flamme victorieuse $L a$, $159 \mathrm{f}$.

Flanders, 12, 160 fï., 200.

Flaubert, 275, 385.

Fleg E., 329 .

Foch, 92.

Foi en la France, $311 \mathrm{ff}$.

Foley, 37\%.

Fontaine-Vive J., 21, 323

f.

Forgues Capt., 183 ff.

Fort Paul, 313 ff., 329.

Fosse aux Lions, 329.

Fouchardière $J$. de la, 377.

Foulet L., 35.

France A., 8, 101, 343, 370 .

France devant l'Allemagne La, $282 \mathrm{ff}$.

France La plus Grande, 280.

Franco-Prussian War, $1 S 7 \mathrm{f} ., 310,342,346$, $364,386,389$.

Franconi G. T., $174 \mathrm{ff}$.

Frangipane et Cie, 55.

Frapié, L., 374.

Frederick the Great, 200,

250. 
Frégeolière R. de la, 203. Fresques de Feu et do Sang, 365.

Fribourg André, 44, 107 ff.

Friedland, 172, 390.

Fritz Chez les, 203.

Fronson J. F., 340, 360. Front littéraire de Demain, 381.

Frontières du Coeur, 364. Fusilliers marins., $160 \mathrm{f}$.

Gagneur Capt. M., 216.

Gars Le, 346.

Gaspard, 30 ff., 50, 54, 77,

$115,159,176,363,382$.

Gaultier Paul, 231.

Gavroche, 31, 53, 304.

Geneviève Ste., 25ז, 347. Genevoix M., 44, 75 ff., 384.

Géniaux Ch., 368.

Gens de Guerre du

Maroc, $70,71$.

Gens du Front, 190.

Gentry R., $159 \mathrm{f}$.

Géraldy P., 220 f., 318, 361.

Gerbéviller, 200.

Germaniades, 295.

Germany, 14, 15, 18, 19,

$26,40,67,84,85,91$,

93, 104, 184, 188, 189, 192 ff., 214-15, 219,
231, 238 ff., 248, 255, 261, 290, 297, 332, 392, 411.

Gessner, 250.

Ghéon L., 25, $311 \mathrm{ff}$.

Ginisty P., 216.

Giraud Victor, 269, 381.

Giraudoux, $102 \mathrm{ff}$.

Gloire de l'Armée française, 329.

Gloires Les Deux, 346.

Goethe, 250 f., 254 ff., 332.

Goncourt, Prix, 30, 33, 42, 115, 138.

Gosses, 379.

Gottfried M a u s r Le Journal de, 368 .

Gotton Connixloo, 375.

Gourmond R. de, 9, 14. Grandes Heures Les, 7. Grandgoujon, 31, 60.

Granvillier J. de, 49.

Gregh F., $307 \mathrm{ff}$.

Guérinière $\mathrm{F}$. de la, 365.

Guerre Rôle social de la, 280.

Guerre et l'Amour La, 361.

Guerre, Madame . . L La, 220 ff., 318.

Guerre et le Progrès La, $275 \mathrm{ff}$.

Guerre Sociale, 17. Guerre Souterraine, 33. 


\section{INDEX}

Guerre sur le IIameau, $373 \mathrm{f}$.

Guerre vue d'une Ambulance, 140.

Guitounes Au seuil des, 78.

Guitry Lucien, 361.

Guitry Saeha, 361.

Gus Bofa, 61, 377.

Guynemer, 55.

Gyp, 221-2.

Halévy Ludovic, 188.

Hamp P., $286 \mathrm{f}$.

Hatred, 10, 23, 85, S6, 151-2, 295.

Hauptmann G., 18, 25.

Hauser H., 292.

Haute-Cour Morale, 20.

Hazard, 202.

Heine, 255, 332.

Hélys Mme. Marc, 217.

Hémard J., 203.

Henches, 22, 23, 41, $84 \mathrm{ff}$.

Hennebois $\mathrm{Ch}_{1 .}, 140,207$ ff.

Hennequin, 346.

Henriot E., 159 .

Henry-Jacques, 332 ff.

Henry-Rosier Marguerite, 225.

Hérriot Ed., 281.

Hermant A., $369 \mathrm{ff}$.

Hervé G., 16, 17, 235.

Heures de Guerre de la
Famille Valadier, 369 ff.

Hirseh Ch.-H., 367.

IIistoire de Quatorze Soldats, 61.

II istoire d'une Compagnie, $153 \mathrm{ff} ., 37$.

Home on the Field of IIonor, 191.

IIomme de Désir L', 265.

Honor (military), 343.

Huard Nme., 191.

Hugo Victor, 31, 233, $236,265,296,304,355$, 390.

Humanism, 17.

Huns (see Barbarians), $74,199,347$.

Huot Dr., 122.

Hyaeinthe-Loyson Paul, 21.

Ibanez B., 365.

Illusioniste L', 361.

Imperialism, 260.

Impromptu du Paquetage $L, 345$.

Ineffacable $L^{\prime}, 299 \mathrm{ff}$.

Infirmiers et Infirmières, $140 \mathrm{f} ., 192$.

Institut et la Guerre L', 228.

Instituteur et la Guerre L'. 22S.

Intelleetualism, $239 \mathrm{ff}$. 


\section{INDEX}

Intellectuals, 19, 43, 239 ff.

French, 24, 43.

German, 18, 251, 276, - 316.

Internationalism, 16.

Intuitionism, $239 \mathrm{ff}$.

Invasion, 8, 188 . -

Jacquet H. M., 346.

Jammes F., 25, 323.

Jaurès, 242, 304 .

Jean-Christophe, 17, 18

ff., 324 .

Jean Gouin, La Brigade des, 160.

Jeanne d'Are, 18, S8, 257, $322,326,348$ ff., 38s, 392.

Jeune Fille aux Joues Roses, 352.

Jeune Fille Française et la Guerre La, 229.

Jeunes Gens A quoi rêvent les, 159.

Jeunesse Ardente, 21, $323 \mathrm{f}$.

Joffre, 104, 318, 347.

Jolivet, 153.

Jolicoeur, Tommy Canadien, 378.

Joug Allemand Hors du, 238.

Jouir, 367.

Jour à l'autre D'un, 357. Lachapelle, 281.
Journal d'un Grand Blessé, 140, $207 \mathrm{ff}$.

Journal d'un Simple Soldat, 204.

Journal d'une Famille pendant la Guerre, 228.

Journal d'une Française, 216.

Jours Déchirants En ces, $330 \mathrm{ff}$.

Jugement Dernier, Le, 120.

Julia Dr. E. F., $95 \mathrm{f}$.

Junod (Junot), 168-9, 171.

Juste Lobel, Alsacien, 364.

Kaiser (see also Imperialism ), 93, 150, 186, $200,240,260$ ff., 296 fi., 377.

Kant, 14, 15, 16, 242, 245，252，254 ff., 262, 332.

Kistemaeker, H., 338, $343 \mathrm{f}$.

Klein Abbé, 140.

Kommandantur, 340.

Krupp, 252, 379.

Kultur, 198, 308, 365, $369,403$. 


\section{INDEX}

La Fayette, 207.

La Hire Marie, 228.

Lamartine, 385.

Lamy P., 228.

Langlois H., 236.

Langlois G., 8 .

Lanux P., 244, 286, 313.

Lapie, 228.

Lasserre P., 249, 255, $25 \pi$.

Laudenbacl, $35 \dot{8}$.

Lavedan H., 7, 338 f., 348.

Lazarine, 376.

Le Bail G., 160.

Le Bon G., 240 f.

Leclerc Max, $325 \mathrm{ff}$.

Leçons de la Guerre, 248 ff.

Lecoq, 295.

Lectures pour une Ombre, $102 \mathrm{ff}$.

Légende des Siécles, 358 $\mathrm{f}$.

Légion Etrangère En

Campagne avec, $162 \mathrm{ff}$.

Légionnaire, 162 ff., 176.

Le Goffic Ch., 53, $160 \mathrm{f}$.

Lemaître J., 249, 256.

Lemercier E. E., $7 \mathrm{~S}$.

Lens Martyr de, 193 ff., 205.

Leroux G., 379.

Le Roux Hugues, $225 \mathrm{f}$. Lessing, 250, 361.
Lettres à une Dame Blanche, 227.

Lettres d'un Combattant, $94 \mathrm{f}$.

Lettres d'un Soldat, 41, $78 \mathrm{ff} ., \mathrm{S} 4,85,94$.

Leune Mme., 192.

Level, MI., 374.

L'Herbier, 356.

Lichtenberger A., 364 .

Liège, 162.

Ligue des Patriotes, 11.

Lille, 192, $200 \mathrm{ff}$.

Lintier, $72 \mathrm{ff} ., 79$.

Lissauer, 295.

Littérature et la Guerre, $275,381$.

London Jack, 2$\rceil 1$.

Lorraine, 9, 12, 46, 107, $173,192,234,236,302$, $342,349,364$ f., 369 .

Lote R., 98, 248 ff.

Loti P., 7.

Louis the Fourteenth, 93, $227,251$.

Loups Les, 375.

Lusitania, 86, 262 f., 370. Luther, 254, 260, $262 \mathrm{f}$. Lysis, 99, $287 \mathrm{ff}$.

Maehard A., 379.

NacOrlan, 3i7.

Maeterlinck, 9, 10, 341 f., 374. 
Main qui tend l'Epée, Martin-Marny, 202. 345.

Maistre Joseph de, 16, 254, 258.

Malabé La, 378.

Mallerbe Henry, 44, 115 ff.

Malvy, 36, 37.

Marceau, ou les Enfants de la République, 343. Marchand d'Estampes Le, 357.

Mareus Aurelius, 79, 167. Varée Fraîche, 286.

Marge du Drame En, 220.

Margueritte Brothers, 157, 364, 359.

Margneritte Panl, 7, 364 ff.

Mariage de Lison, 373.

Mariée en 1914, 367.

Marne Battle of, 5, 12,

$17,19,52,53,72,74$, $103,105,106,121$, $160,175,179,180,185$, $185,190,236,303,315$ ff., 348, 389 .

Marraines, 229.

Martyre de Lens, $193 \mathrm{ff}$. Martyrs Vie des, $121 \mathrm{ff}$. Marx K., see Socialism. Massacre des Innocents, 379.

Massis H., 21, 25, 253, $263 \mathrm{ff} ., 384$.

Mauclair C., 35, 381.

Maupassant, 2S, 189.

Maurel A., 16, 263, 284.

Maurois A., 378.

Maurras Ch., 237, 249, $257,274$.

Mayran Camille, 375.

Médecins, 208-11.

Médecin de France, Un, 123.

Méditations dans la Tranchée, $87 \mathrm{ff}$.

Mercier (Cardinal), 258. Mercier Louis, $319 \mathrm{ff}$.

Mercure de France, 24, 124, 139, 395.

$M$ ét hode $s$ allemandes d'Expansion, 282.

Métiers Blessés, 256.

Meuse, 18S, 200.

Michaux Baronne J., 220.

Marseillaise, $304 \mathrm{ff} ., 314$, Michel, $50 \mathrm{ff} ., 53,5 \mathrm{~s}$. 333.

Marsouille, La, 123.

Marthe Steiner, 366.

Michelet, 232.

Milan René, 182.

Marthold J. de, 295.

Martin L. L., 368.

Military Life, 400.

Mille Pierre, 374.

Mines, $285 \mathrm{ff}$. 


\section{INDEX}

Mirabelle de Pampelune, 375.

Miracle du Feu, 50 ff., 372.

Miracle Français, 269, $329,351$.

Missionnaire Le, 369.

Mômes Guerre des, 379.

Montesquieu, 290.

Moral regeneration, 52.

Moralism, $242 \mathrm{f}$.

Moraud E., 348 .

Moroceo, 69, 70, 71, 110, 111, 203, $253 \mathrm{f}$. (See also Gens de Guerre du Maroc.)

Mort au Champ d'Honneur, $225 \mathrm{f}$.

Mort du Soldat, $95 \mathrm{f}$.

Mortier A., 361, 381.

Mort Sens de la, 154, 376.

Moselly E., 372.

Mourey G., 303.

Mousquetaires, 54, 343.

Mousquetaires Les derniers, $5 \overline{\text { i. }}$.

Muller Major, $164 \mathrm{ff}$.

Mur des Pleurs Le, 329.

Musset A. de, $3 \$ 5$.

Mystère des Béatitudes, 222.

Nadaud M., 53 ff.

Napoléonic Wars, 146, $277,358$.

Nationalism, $256 \mathrm{f}$.

Natorp, $214 \mathrm{f}$.

Nénesse, 15?.

Neo-Catholieism, $255 \mathrm{ff}$, $27+$ f., 3S1. (See Catholicism.)

Népoty l., $35 \mathrm{~s} \mathrm{f}$.

Nentrality, 21. ( S e e also Rolland.)

Neuville-Saint-Vaast, 170. Nereu de l'Oncle Sam, 3 is.

Newspapers and Periodicals, 6 .

Nion Fr. de, $36 s$.

Niox, 216.

Nieuport, 160.

Nietzsche, 25+ff., 332.

Noailles Madame de, 302, 329.

Noces d'Argent, 361.

Nolly, 70, 71, s.9.

Non-combattants, $159 \mathrm{ff}$.

Normand Gilles, 329.

Notes d'une Internée Française, 216.

Nothomb P., 9.

Notre Patrie, 16, 235.

Nous, de la Guerre, 332 ff.

Nonveaux Chants du Soldat, 293.

Nourelle Revue Fran427 


\section{INDEX}

çaise, 13, 14, 236, 286, $317,387$.

Novel (see War-novel, and War-Time novel).

Nozière, 340.

Nuit de Noèl de 1914, 346, 379 .

Nuits de Guerre, 78.

Oberlé Les, 364.

Oberlé Les Nouveaux, 364.

Obus Sous L', 61.

Odyssée d'un Transport Torpillé, $182 \mathrm{ff}$.

Oeuvre de Demain, 281.

Ollivier, Cap., 212.

Oncle Sam Neveu de l', 378.

Onze Mois de Captivité, 212.

Orage F., (see also Candive $), 101 \mathrm{ff}$.

Orgueil Français La Renaissance de, $271 \mathrm{ff}$.

Pacifism, Defeatism, etc., 37, 99, 110, 255.

“Pamir," $183 \mathrm{ff}$.

Pan-Germanism, 214, 232, 238, 252, 254.

Papalism, $255 \mathrm{ff}$.

Fape, la Guerre et la Paix Le, 258 ff.
Parisienne et la Guerre La, 229.

Parisienne en Temps de Guerre, Souvenirs d'une, 229.

Parodi, 246.

Parti de l'Intelligence, Pour le, 25.

Passion de Notre Frère le Poilu, $325 \mathrm{ff}$.

Pasteur Louis, 308.

Patrie, 17, 342, 367.

Notre, 16, 235.

Leur, 16, 235.

Patriotism, 88.

Patté Paul, 223-5.

Pawlowski G. de, 61, 285. Péguy, 13, 16, 234, 244, $246,257,264,271,293$ ff., 30s, 315, 350.

Peine des Hommes, 286. Peladan, 8.

Pélerin Mutilé, 121.

Pendant la Guerre, 368.

Pendant qu'il se bat, 368. Péricard Jaeques, 147 ff., 384.

Periodicals (see Newspapers).

Physicians (Writers), $121 \mathrm{ff}$.

Physiocrats, 290.

Pichon, 262.

Pièce Ma, 72 ff.

Pierrette, 373. 


\section{INDEX}

Pingaud,

Pingot et Moi, $66 \mathrm{ff} ., 91$.

Pinguet J., 160.

Pipe Major, 31, $59 \mathrm{ff}$.

Plus Haut que l'Amour, 356.

Poèmes de la Délivrance, 318.

Poèmes de France, 313.

Poèmes de la Tranchéc, $319 \mathrm{ff}$.

Poètes de la Guerre, 329.

Poil civil Gazette, 227.

Poilu, 150, 325 f., $35 \pm$ f.

Poilu Le, 346.

Poilu, see Passion,

Poing de Fer Sous le, 201.

Poissons Morts, 3ī.

Pope, 87. (See also Church, etc.)

Porché F., 317 f., 349 ff., 384.

Porto-Riehe G. de, 357. Portraits de la Belle France, 225.

Possession du Monde, 139.

Post-War Literature, 381, 388.

Pottecher M., 303.

Poulbot, 379, 404.

Pour Renaître, 257 ff.

Prévost M., $364 \mathrm{f}$.

Pre-War Literature, 388.
Prière dans la Nuit, 340. I'rières de la Tranchée, $319 \mathrm{ff}$.

Prieur, 216.

Prisoners, 202 ff., 402.

Prisonnier en Allemagne, 203.

Prisonnier de Guerre, 202.

Prisomniers Délirés, 153. Prix de l'Ilomme, 49.

Probus, 280.

Propaganda, 366.

Protestants, 96, 236, 259, 266, 323, 392.

Prorinces pendant la Guerre Les. See Alphaud.

Prussianism, 15, 25, 111, $150,232,290$.

Psiehari E., 70, 71, 95, $26+\mathrm{f}$.

Quatrefages B. de, 8. Quinet Edgar, $231 \mathrm{f}$., 249.

Rail Le, 286.

Rathenau M., 290.

Récits d'un Soldat, 188. Récits du Temps de la Guerre, 374.

Red Cross, 152, 158, 192-3, 204, 216.

Rédier A., 44, 87 ff., 373. 


\section{INDEX}

Reformation, 259 f., 263.

See also Protestantism. Régiment Russe Mon, 68. Remarques, 14.

Renaissance, 384, 386.

Renan, 101, 219, 233.

Représailles, 212-13.

Réveil de l'Esprit Le, $266 \mathrm{ff}$.

Revolution French, 107, $240,254,266,288,290$, $385 \mathrm{ff}$.

Rey Etienne, $271 \mathrm{ff}$.

Rheims, 125, 190, 200, $306,348,349$.

Rhine, 18, 233, 369.

Ribot Th., 246.

Richepin Jacques, 361.

Richepin Jean, 7 .

Rides du Front Dans les, 285.

Right (and Might), 20, 245 f., $255,262$.

Rimbaud Isabelle, $190 \mathrm{f}$.

Riou G., 203 ff., 323.

Rivière Jacques, 213 ff., 254.

Rivoli, 172, 390.

Roë Art (Pseudonym for

Patrice Mahon), 66 ff., $70,71,88,91$.

Roland, 79, 342. 388 ff.

Rôle social de la Guerre, 280.

Rolland Romain, 16, 24,

87, 96, 255, 276, 324.

Romains Jules, 124.

Roman de l'Energie $\mathrm{Na}$ tionale, 233, 257. See also Barrès.

Roman Catholicism. See Catholicism.

Roman Militaire en France 1870-1914, 71, 393.

Romanticism, 246, 249, $257,282,385 \mathrm{f}$.

Rornach Admiral, 161.

Rostand, 304 ff., 329, 353, $389,393$.

Rougier P., 318.

Rouletabille, 379.

Rousseau, 49, 231, 249, 262, 266 ff., 279, 282, 291.

Roussel-Iépine T., 140. Rouves Ch. de, 369. Roux-Parnasse E., 164. Ruins (see words like Destruction, Barbarians, ete).

Russia, 165, 173, 206, 239, 270.

Sacrifice Le, 263 ff., 358. Sacrifices Les, 349.

Sageret J., 99, 275 ff. Saint-Dié, 202.

Sainte-Geneviève, 257, 347. 
Saint-Mihiel, 207.

Saint-Quentin, 179, 202.

Sammy, Volontaire Américain, 37s.

Sang du Sacrifice Le, 299.

Sang Le, 50.

Sardou, 342.

Schelling Friedrich, 255.

Scipion Pégoulade, 377.

Sedan, 188, 389.

Seillière E., 249, 257.

Sem, 404.

Senlis, 200, $309 \mathrm{f}$.

Sens de la Mort, 154, 375. Sentiments de Critias, 21.

Sept Paralipomènes, 329. Servir, 338 f.

Service de l'Allemagne Au, 234.

Service de l'Ennemi Au, 369.

Servitude et grandeur Militaire, 65.

Short Story, 61 f., 374 f.

Sicard E., 351.

Signaux à L'Ennemi, 61. Silences du Colonel Bramble Les, $37 \mathrm{~S}$.

Six Femmes et l'Invasion, 192.

Socialism, 16, 19, 242, 252, 259, 290, 392.

Soir au Front. 343.

Soldats de 1914, 302.
Sorbonne Esprit de la

Nouvelle, 253.

Soufles de Tempête, $30^{\circ}$.

Soulié, 340.

Sous leur Dictée, 37 t.

Souvenirs de Tranchée, 327.

Spy, 187, 237 ff., 338, 364 ff., 392.

Staël Mme. de, 385.

Steenstraete, 160.

Steinmetz, 280.

Suarès André, 13, 14, 15, $236,254$.

Suberville J., 329, 354 f.

Switzerland, 212, 258.

Sylvette et son Blessé, 377.

Taboureau, 33.

Taine, 233, 246, 375.

Talmayre M., 225.

Tambour Sur un, 374.

Tank, 175, 181.

Tarde, 253, 264.

Targette, 170.

T'émoin Le, 299.

Tenir, $157 \mathrm{f}$.

Terre Natale, 366.

Terre qui nait. 375.

Terrorization, 5, 151, 341 .

Thamin R., 228.

Théâtre aux Armées, 346.

Théatre des Alliés, 351.

Théâtre Héroïque, 264. 


\section{INDEX}

Théâtre pendant la Université et la Guerre Guerre, 361.

$L$, 228.

Thierry Albert, 203, 412. Urville Mme. d', 192.

Thomas Louis, $141 \mathrm{ff}$., 148.

Tinayre Marcelle, 190, 217.

Torpilleur 80000 Milles en, 158, 181.

Totoche, Prisonnier de Guerre, 378.

Traits Eternels de la France, 12, 303.

Treitzschke, 252.

Tribulations d'un Auxiliaire, 59.

Trois Etapes, 160, 182.

Trois Poèmes de Guerre, $315 \mathrm{ff}$.

Trouillot G., 304.

True G., 263.

Tu n'es Plus Rien, 372.

Tube 1233 Le, 72, 73.

Turoldus, 388.

Types Soldier-in Novels, $27 \mathrm{ff}$.

Una, 329.

Un Tel de l'Armée Française, 174.

Union Sacrée, 7, 11. United States, 13, 40, Victóry, 382.

$173,186,270,274,288$, 290.

Vagabonds de la Gloire les, 182.

Vaissette, 44 ff., 50, 101. Vallery-Radot R., $264 \mathrm{ff}$. Vallotton B., 200, 375.

Vandalism, 197, 198, 200. Vauquois, 31. (See also Verdun.)

Vaux Fort de, 153.

Veber P., 346.

Veillée d'Armes, $358 \mathrm{f}$.

Veillée des Armes, 190, 217.

Veillée du Centurion, 70, 95.

Verhaeren, 9, 295 ff.

Verlet P., 329.

Vermine du Monde, 366. Vernet, 357.

Verdun, 13, 14, 31, 56, $57,59,75,121,126$, 147 ff., 153 ff., 160, 176, $180,296,308,323,351$, 389.

Verdun Ceux de, 147 ff. Verdun Sous, $75 \mathrm{ff}$.

Vic J., 26, 255, 363, 391. Victor et ses Amis, 379.

Victoire La, 17.

Vie des Martyrs, $121 \mathrm{ff}$. 
Vierge de Lutèce, 3 ti ti.

Vignand, 61.

Vignes-liouges Jean des, $31 \mathrm{ff}$.

Vigny A. de, 65, 66, 87, 89.

Villèle Aline de, 366.

Villeroy A., $34 \bar{f} \mathrm{f}$.

Vin de Champagne, $2 \mathrm{St}$.

Visme Henriette de, 22!.

Vivre pour la latrie, 374.

Vocance J., 328.

Voivenel Dr., 122.

Voix dans la Fournaise, 329.

Vol de la Marseillaise, $304 \mathrm{ff}$.

Volontaires, 164, 211.

Voltaire, 46, 101, 250, 290.

Von Kommenden Dingen, 290.

Vosges, 142, 146, 147.

\section{Wagner R., 332.}

War as a Means of $\mathrm{Se}$ lection, 280.

War Canse of, $275 \mathrm{ff}$.

War-Diaries and War-
Recollections, 30,62 ff.. $141 \mathrm{ff} ., 187$.

War Italian, 384.

Napoleonic, 146, 277, 385.

War-Lords, see Kaiser, ete.

Warnod A., $202 \mathrm{f}$.

War-Novel, 27 ff., 363.

War-Time-Novel, 29 ff., 363 if.

Wells H. G., 285, 305.

Werth, L., 4?.

Wetterlé Abbé, 9, 369.

Wilde Robert de, 162.

Tilliams H. Isabelle, $127 \mathrm{ft}$.

Wolf P., 346.

$\mathrm{Y}-182 \mathrm{ff}$.

Yerta Mme., 192.

Ypres, 147.

Yser, 161, 162, 389.

Yver, Colette, 222, 375 , 378.

Zamacoïs, 299 ff., 346, 349. Zavic E., 203.

Zola, 197, 343, 364, 396. 389. 
$\nabla=*$

IR⿴囗十 $=4 \quad$ is 
